Prepared in cooperation with the Alaska Division of Geological \& Geophysical Surveys and the Bureau of Land Management

\title{
GIS-Based Identification of Areas that have Resource Potential for Lode Gold in Alaska
}

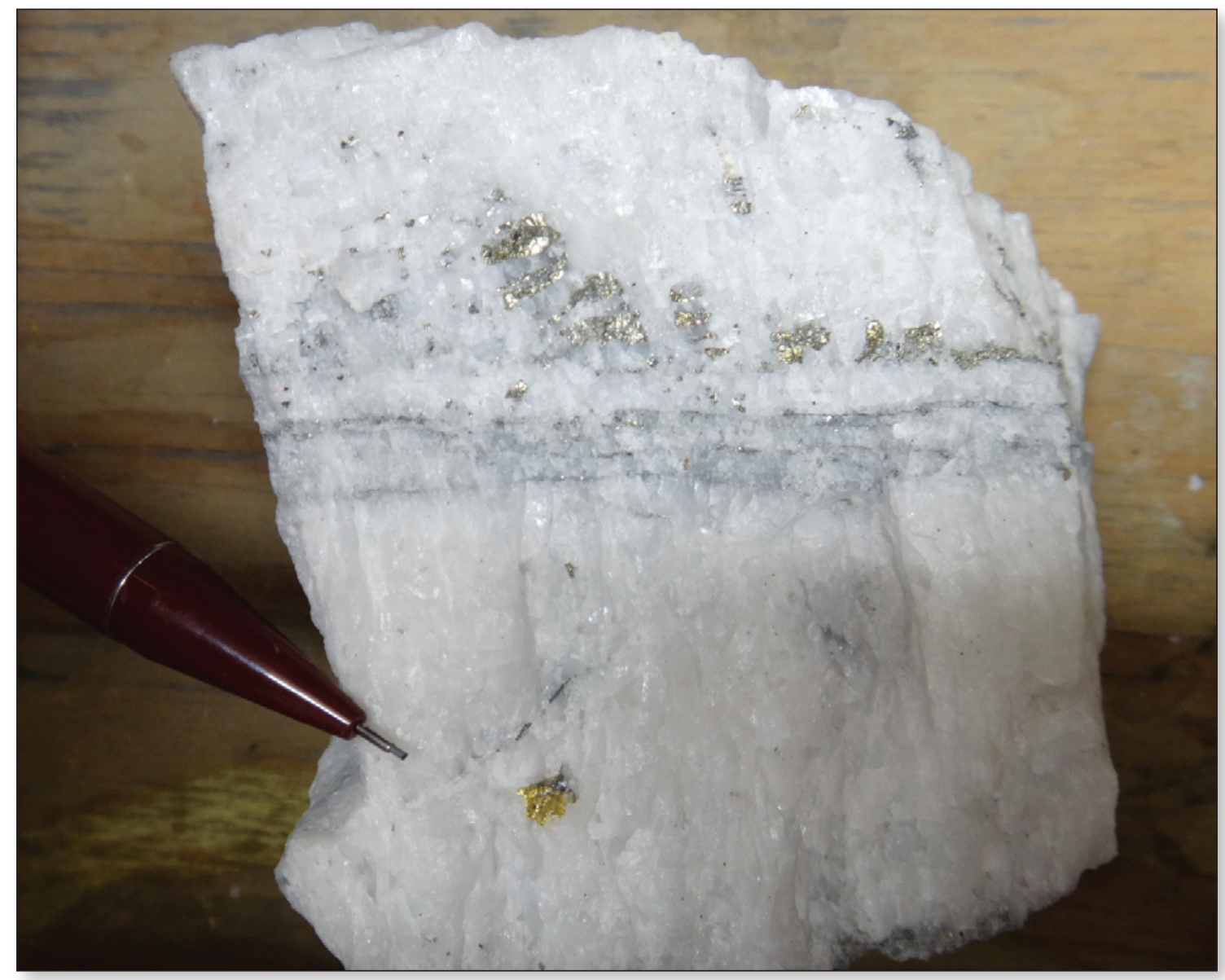

Open-File Report 2021-1041 
Cover. Photograph of gold, tellurides, and sulfide minerals in quartz from the Kensington Mine, southeastern Alaska. Pencil for scale. Photograph taken by Susan Karl, USGS. 


\section{GIS-Based Identification of Areas that have Resource Potential for Lode Gold in Alaska}

By Susan M. Karl, Douglas C. Kreiner, George N.D. Case, Keith A. Labay, Nora B. Shew, Matthew Granitto, Bronwen Wang, and Eric D. Anderson

Prepared in cooperation with the Alaska Division of Geological \& Geophysical Surveys and the Bureau of Land Management

Open-File Report 2021-1041 


\section{U.S. Geological Survey, Reston, Virginia: 2021}

For more information on the USGS — the Federal source for science about the Earth, its natural and living resources, natural hazards, and the environment-visit https://www.usgs.gov or call 1-888-ASK-USGS.

For an overview of USGS information products, including maps, imagery, and publications, visit https://store.usgs.gov.

Any use of trade, firm, or product names is for descriptive purposes only and does not imply endorsement by the U.S. Government.

Although this information product, for the most part, is in the public domain, it also may contain copyrighted materials as noted in the text. Permission to reproduce copyrighted items must be secured from the copyright owner.

Suggested citation:

Karl, S.M., Kreiner, D.C., Case, G.N.D., Labay, K.A., Shew, N.B., Granitto, M., Wang, B., and Anderson, E.D., 2021, GISbased identification of areas that have resource potential for lode gold in Alaska: U.S. Geological Survey Open-File Report 2021-1041, 75 p., 9 plates, https://doi.org/10.3133/ofr20211041.

Associated data for this publication:

Karl, S.M., Kreiner, D.C., Case, G.N.D., Labay, K.A., Shew, N.B., Granitto, Matthew, Wang, Bronwen, and Anderson, E.D., 2021, Data and results for GIS-based identification of areas that have resource potential for lode gold in Alaska: U.S. Geological Survey data release, https://doi.org/10.5066/P9CAM3F9.

ISSN 2331-1258 (online) 


\section{Contents}

Acknowledgements........................................................................................................................

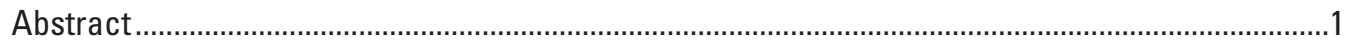

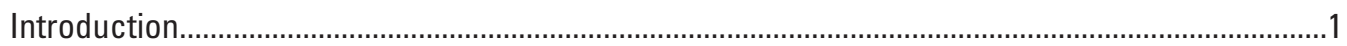

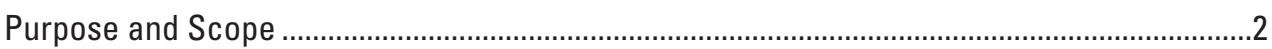

Lode Gold Deposit Definition and Classification ......................................................................2

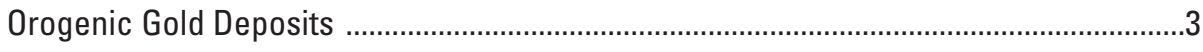

Intrusion-related Gold Deposits ......................................................................................

Epithermal Gold Deposits ................................................................................................

Data Types and Analytical Process ...............................................................................................

National Hydrography Dataset and Watershed Boundary Dataset............................................

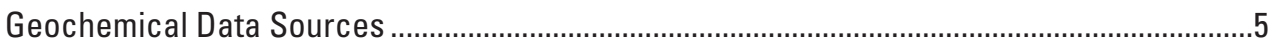

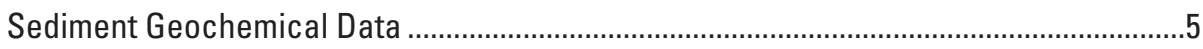

Rock Geochemical Data ..................................................................................................

Heavy Mineral Concentrate Mineral and Geochemical Data ............................................7

Alaska Resource Data File .................................................................................................

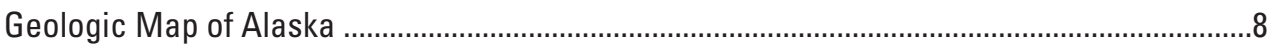

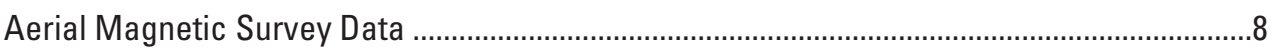

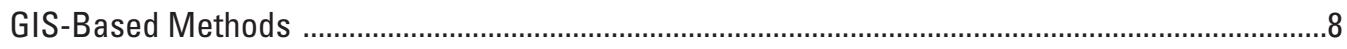

Chapter 1. Lode Gold Deposits—Undivided ............................................................................

Deposit Group Characteristics ..........................................................................................

Mineral Resource Potential Estimation Method ………….....................................................10

Lithology ........................................................................................................... 10

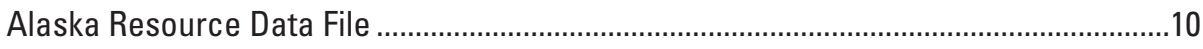

Rock and Sediment Geochemical Data ......................................................................

Heavy Mineral Concentrate Data ...............................................................................11

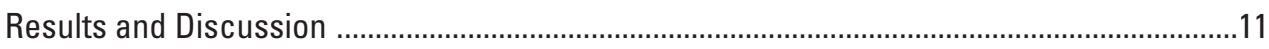

Areas that have Known and Newly Recognized Prospectivity for Lode Gold Deposits 11

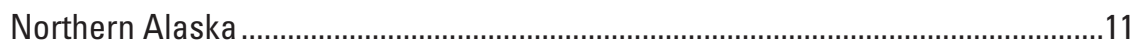

Northwestern Alaska ................................................................................................11

East-Central Alaska ..............................................................................................12

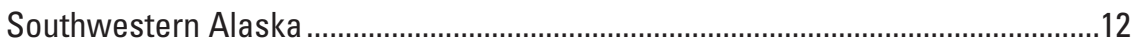

South-Central and Southeastern Alaska .............................................................12

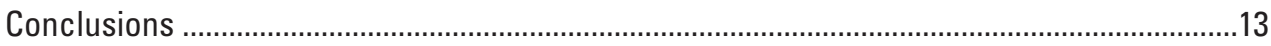

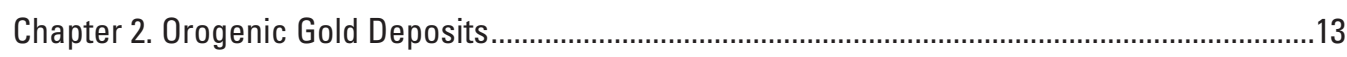

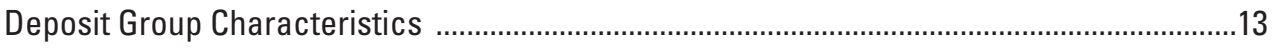

Mineral Resource Potential Estimation Method ...................................................................14

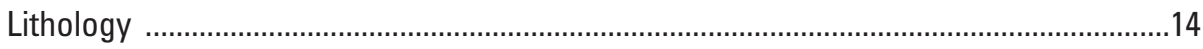

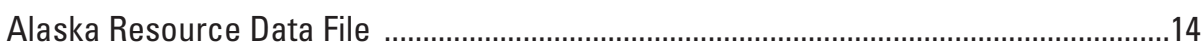

Rock and Sediment Geochemical Data ..................................................................14

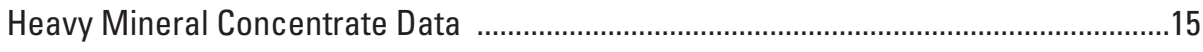

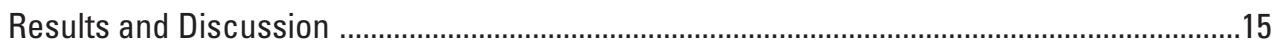

Areas that have Known and Newly Recognized Prospectivity for Orogenic Gold

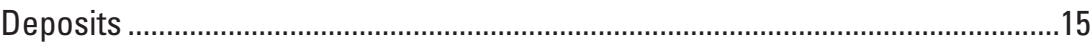

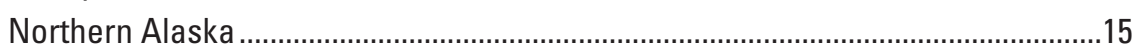


Seward Peninsula and North-Central Alaska ........................................................16

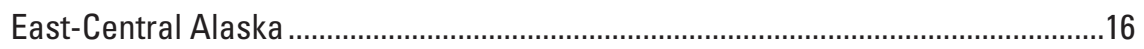

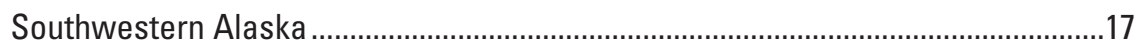

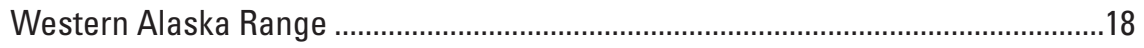

South-Central Alaska ..............................................................................................18

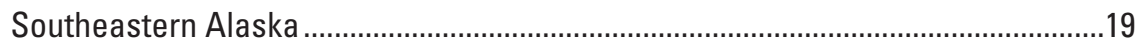

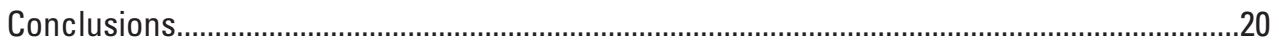

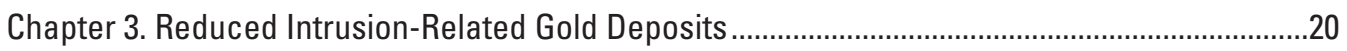

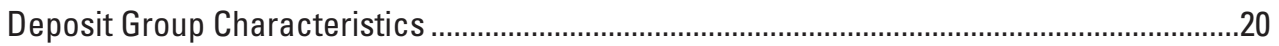

Mineral Resource Potential Estimation Method ......................................................................21

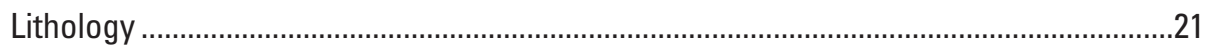

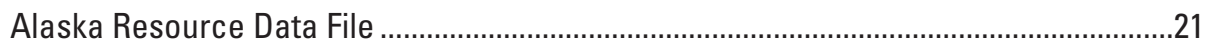

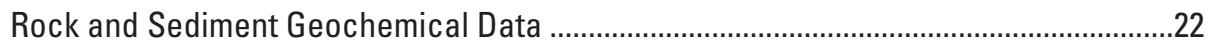

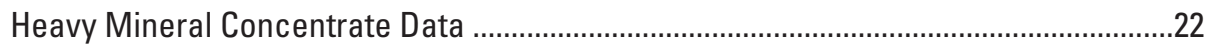

Aerial Magnetic Survey Data ...................................................................................22

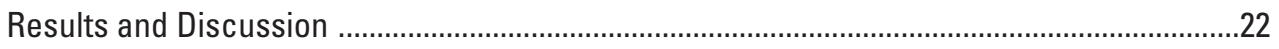

Areas that have Known and Newly Recognized Prospectivity for Intrusion-Related

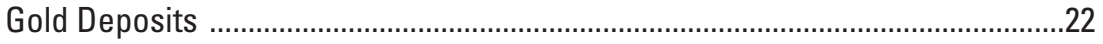

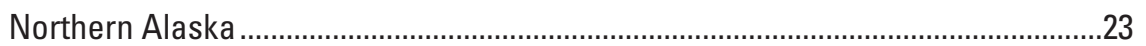

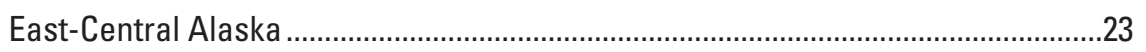

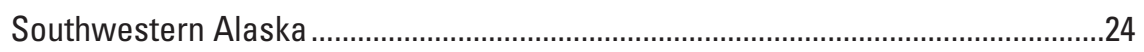

Western Alaska Range ...................................................................................25

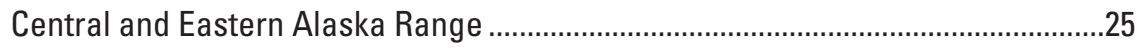

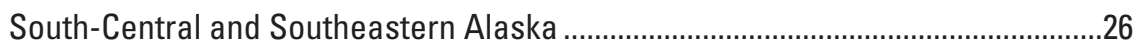

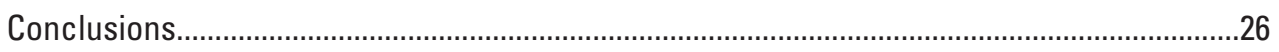

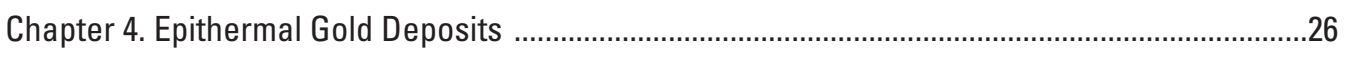

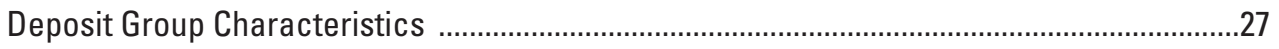

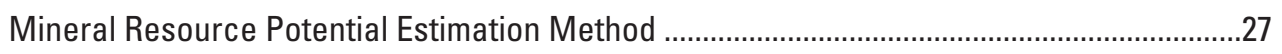

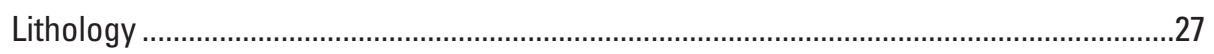

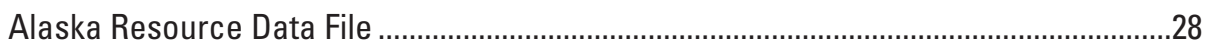

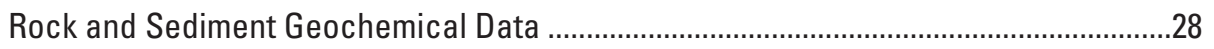

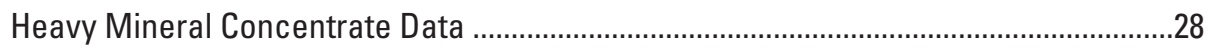

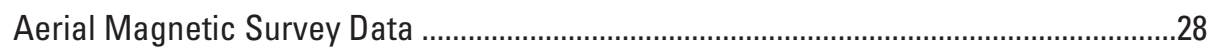

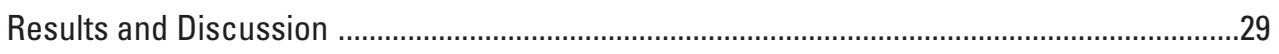

Areas that have Known and Newly Recognized Prospectivity for Epithermal Gold

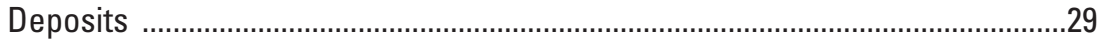

Alaska Peninsula and Aleutian Islands ................................................................29

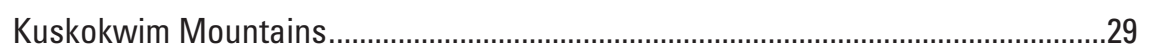

Alaska Range ....................................................................................................

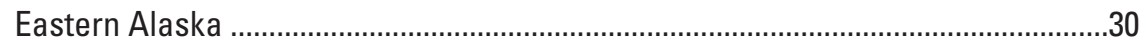

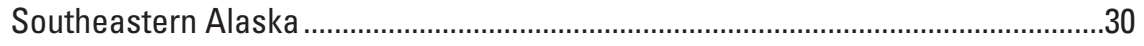

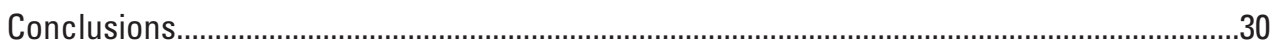

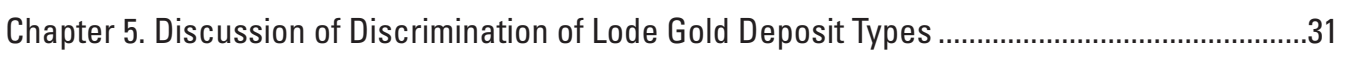

Method to Evaluate Deposit Model Overlap ……….............................................................

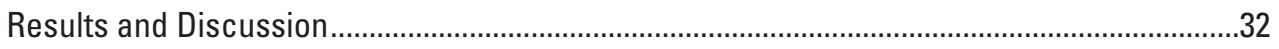


Chapter 6. Gold-Bearing Porphyry and Epithermal Gold Deposits .................................................32

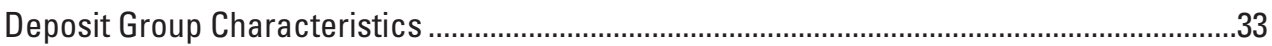

Mineral Resource Potential Estimation Method ...................................................................33

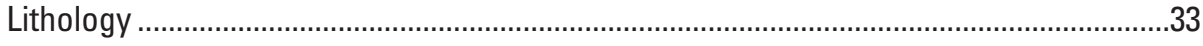

Alaska Resource Data File ..............................................................................................

Rock and Sediment Geochemical Data ......................................................................

Heavy Mineral Concentrate Data ......................................................................................

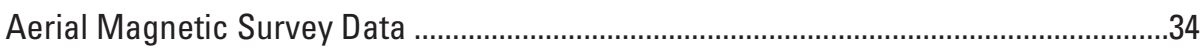

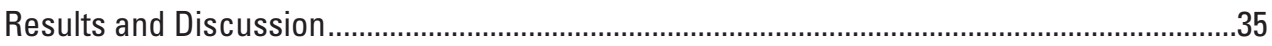

Areas that have Known Prospectivity for Gold-Bearing Porphyry and Epithermal Gold

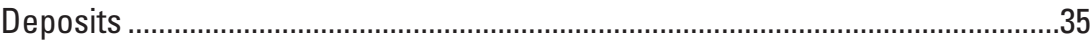

Areas that have Newly Recognized Prospectivity for Gold-Bearing Porphyry and

Epithermal Gold Deposits in Alaska ........................................................................35

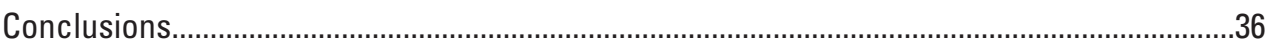

Chapter 7. Reduced Intrusion-Related and Orogenic Gold Deposits............................................36

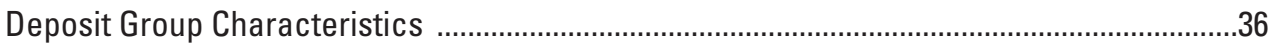

Mineral Resource Potential Estimation Method …………....................................................36

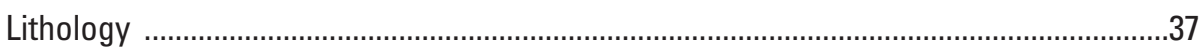

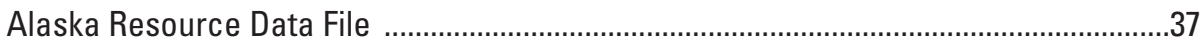

Rock and Sediment Geochemical Data ....................................................................37

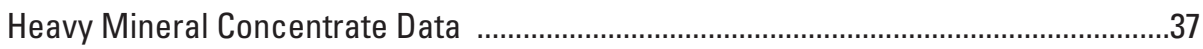

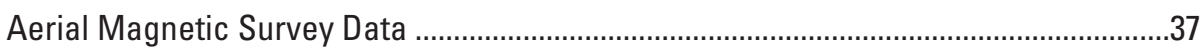

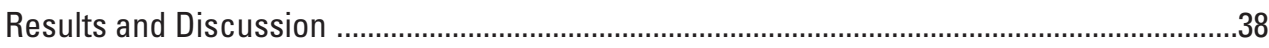

Areas that have Known Prospectivity for Reduced-Intrusion-Related and Orogenic

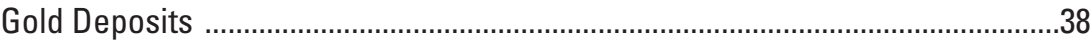

Areas that have Newly Recognized Prospectivity for Reduced-Intrusion-Related and

Orogenic Gold Deposits ..................................................................................3

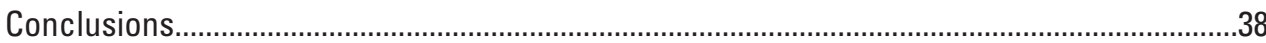

Chapter 8. Discussion of Discrimination of Lode Gold Deposit Types Using Model Combinations

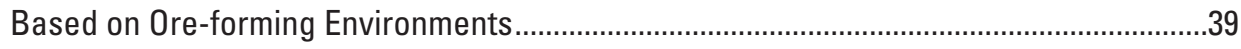

Method to Evaluate Deposit Model Group Overlap .............................................................39

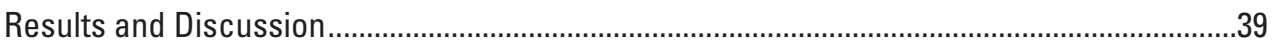

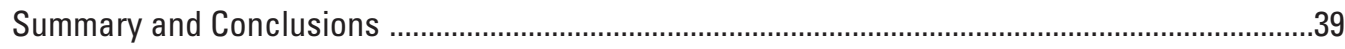

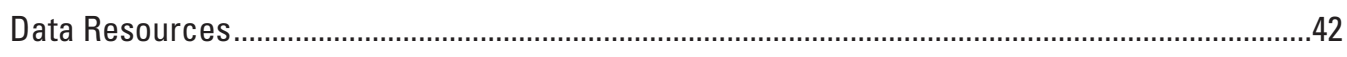

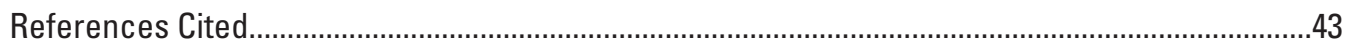

Appendix 1. Statistical Calculations of Levels of Background Values for Sediment and Rock

Geochemical Data........................................................................................................53

Appendix 2. Alaska Resource Data File (ARDF) Mineral-Deposit-Keyword-and-Scoring

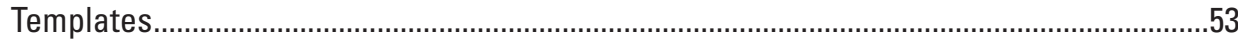

Appendix 3. Lithology-Keyword Search Terms for the "Geologic Map of Alaska" .........................53

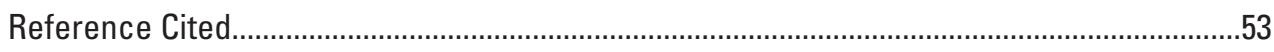

\section{Figure}

1. Physiographic map of Alaska showing place names and major faults, which provide a reference frame for locating regional trends in prospectivity. 


\section{Tables}

1. Lode gold deposit types in Alaska that were considered in this study and their commodities, characteristics, representative localities, and references.

2. Scoring template for analysis of undivided lode gold potential within each hydrologic unit code (HUC) in Alaska.

3. Mineral resource potential versus certainty classification matrix for undivided lode gold deposits in Alaska.

4. Scoring template for analysis of potential for orogenic gold deposits within each hydrologic unit code (HUC) in Alaska.

5. Mineral resource potential versus certainty classification matrix for orogenic gold deposits in Alaska.

6. Scoring template for analysis of potential for intrusion-related gold deposits within each hydrologic unit code (HUC) in Alaska.

7. Mineral resource potential versus certainty classification matrix for intrusion-related lode gold deposits in Alaska.

8. Scoring template for analysis of potential for epithermal gold deposits within each hydrologic unit code (HUC) in Alaska.

9. Mineral resource potential versus certainty classification matrix for epithermal gold deposits in Alaska.

10. Scoring template for analysis of potential for porphyry and epithermal gold deposits within each hydrologic unit code (HUC) in Alaska.

11. Mineral resource potential versus certainty classification matrix for porphyry and epithermal gold deposits in Alaska.

12. Scoring template for analysis of potential for reduced-intrusion-related and orogenic gold deposits within each hydrologic unit code (HUC) in Alaska.

13. Mineral resource potential versus certainty classification matrix for reduced-intrusionrelated and orogenic gold deposits in Alaska.

14. Summary of primary discriminating parameters for GIS-based prospectivity analyses for lode gold.

\section{Plates}

[Available online at https://doi.org/10.3133/ofr20211041]

1. Estimated Resource Potential and Certainty for Lode Gold-Undivided Deposits

2. Estimated Resource Potential and Certainty for Lode Gold-Undivided Deposits and Alaska Resource Data File Localities

3. Estimated Resource Potential and Certainty for Orogenic Gold Deposits

4. Estimated Resource Potential and Certainty for Reduced Intrusion-related Gold Deposits

5. Estimated Resource Potential and Certainty for Epithermal Gold Deposits

6. Map Showing Overlap of Orogenic, Intrusion-related and Epithermal Gold Deposit Prospectivity Maps

7. Estimated Resource Potential and Certainty for Combined Gold-bearing Porphyry and Epithermal Gold Deposits

8. Estimated Resource Potential and Certainty for Combined Reduced Intrusion-related and Orogenic Gold Deposits

9. Map Showing Overlap of Gold-bearing Porphyry-Epithermal Gold and Reduced Intrusion-related-Orogenic Gold Deposit Prospectivity Maps 


\section{Acknowledgments}

Special thanks to Garth Graham, U.S. Geological Survey, and Melanie Werdon, Alaska Division of Geological \& Geophysical Surveys, for constructive and helpful reviews. Thanks also to John Hoppe, Bureau of Land Management, for helpful data and discussions.

\section{Conversion Factors}

U.S. customary units to International System of Units

\begin{tabular}{|c|c|c|}
\hline Multiply & By & To obtain \\
\hline \multicolumn{3}{|c|}{ Length } \\
\hline inch (in.) & 2.54 & centimeter $(\mathrm{cm})$ \\
\hline inch (in.) & 25.4 & millimeter (mm) \\
\hline foot $(\mathrm{ft})$ & 0.3048 & meter $(\mathrm{m})$ \\
\hline mile (mi) & 1.609 & kilometer (km) \\
\hline mile, nautical (nmi) & 1.852 & kilometer (km) \\
\hline yard (yd) & 0.9144 & meter $(\mathrm{m})$ \\
\hline \multicolumn{3}{|c|}{ Area } \\
\hline acre & 0.004047 & square kilometer $\left(\mathrm{km}^{2}\right)$ \\
\hline square foot $\left(\mathrm{ft}^{2}\right)$ & 929.0 & square centimeter $\left(\mathrm{cm}^{2}\right)$ \\
\hline square foot $\left(\mathrm{ft}^{2}\right)$ & 0.09290 & square meter $\left(\mathrm{m}^{2}\right)$ \\
\hline square inch $\left(\mathrm{in}^{2}\right)$ & 6.452 & square centimeter $\left(\mathrm{cm}^{2}\right)$ \\
\hline section (640 acres or 1 square mile) & 259.0 & square hectometer $\left(\mathrm{hm}^{2}\right)$ \\
\hline square mile $\left(\mathrm{mi}^{2}\right)$ & 259.0 & hectare (ha) \\
\hline square mile $\left(\mathrm{mi}^{2}\right)$ & 2.590 & square kilometer $\left(\mathrm{km}^{2}\right)$ \\
\hline cubic inch $\left(\mathrm{in}^{3}\right)$ & 16.39 & cubic centimeter $\left(\mathrm{cm}^{3}\right)$ \\
\hline cubic inch $\left(\mathrm{in}^{3}\right)$ & 0.01639 & cubic decimeter $\left(\mathrm{dm}^{3}\right)$ \\
\hline cubic foot $\left(\mathrm{ft}^{3}\right)$ & 28.32 & cubic decimeter $\left(\mathrm{dm}^{3}\right)$ \\
\hline cubic foot $\left(\mathrm{ft}^{3}\right)$ & 0.02832 & cubic meter $\left(\mathrm{m}^{3}\right)$ \\
\hline cubic yard $\left(\mathrm{yd}^{3}\right)$ & 0.7646 & cubic meter $\left(\mathrm{m}^{3}\right)$ \\
\hline cubic mile $\left(\mathrm{mi}^{3}\right)$ & 4.168 & cubic kilometer $\left(\mathrm{km}^{3}\right)$ \\
\hline acre-foot (acre-ft) & 1,233 & cubic meter $\left(\mathrm{m}^{3}\right)$ \\
\hline acre-foot (acre-ft) & 0.001233 & cubic hectometer $\left(\mathrm{hm}^{3}\right)$ \\
\hline \multicolumn{3}{|c|}{ Mass } \\
\hline ounce, avoirdupois (oz) & 28.35 & gram $(\mathrm{g})$ \\
\hline pound, avoirdupois (lb) & 0.4536 & kilogram (kg) \\
\hline ton, short $(2,000 \mathrm{lb})$ & 0.9072 & metric ton $(\mathrm{t})$ \\
\hline ton, long $(2,240 \mathrm{lb})$ & 1.016 & metric ton $(\mathrm{t})$ \\
\hline \multicolumn{3}{|c|}{ Pressure } \\
\hline atmosphere, standard (atm) & 101.3 & kilopascal $(\mathrm{kPa})$ \\
\hline bar & 100 & kilopascal $(\mathrm{kPa})$ \\
\hline \multicolumn{3}{|c|}{ Density } \\
\hline pound per cubic foot $\left(\mathrm{lb} / \mathrm{ft}^{3}\right)$ & 16.02 & kilogram per cubic meter $\left(\mathrm{kg} / \mathrm{m}^{3}\right)$ \\
\hline pound per cubic foot $\left(\mathrm{lb} / \mathrm{ft}^{3}\right)$ & 0.01602 & gram per cubic centimeter $\left(\mathrm{g} / \mathrm{cm}^{3}\right)$ \\
\hline
\end{tabular}


International System of Units to U.S. customary units

\begin{tabular}{|c|c|c|}
\hline Multiply & By & To obtain \\
\hline \multicolumn{3}{|c|}{ Length } \\
\hline centimeter $(\mathrm{cm})$ & 0.3937 & inch (in.) \\
\hline millimeter $(\mathrm{mm})$ & 0.03937 & inch (in.) \\
\hline meter $(\mathrm{m})$ & 3.281 & foot $(\mathrm{ft})$ \\
\hline kilometer (km) & 0.6214 & mile (mi) \\
\hline kilometer $(\mathrm{km})$ & 0.5400 & mile, nautical (nmi) \\
\hline meter $(\mathrm{m})$ & 1.094 & yard (yd) \\
\hline \multicolumn{3}{|c|}{ Area } \\
\hline square meter $\left(\mathrm{m}^{2}\right)$ & 0.0002471 & acre \\
\hline hectare (ha) & 2.471 & acre \\
\hline square hectometer $\left(\mathrm{hm}^{2}\right)$ & 2.471 & acre \\
\hline square kilometer $\left(\mathrm{km}^{2}\right)$ & 247.1 & acre \\
\hline square centimeter $\left(\mathrm{cm}^{2}\right)$ & 0.001076 & square foot $\left(\mathrm{ft}^{2}\right)$ \\
\hline square meter $\left(\mathrm{m}^{2}\right)$ & 10.76 & square foot $\left(\mathrm{ft}^{2}\right)$ \\
\hline square centimeter $\left(\mathrm{cm}^{2}\right)$ & 0.1550 & square inch $\left(\mathrm{ft}^{2}\right)$ \\
\hline square hectometer $\left(\mathrm{hm}^{2}\right)$ & 0.003861 & section (640 acres or 1 square mile) \\
\hline hectare (ha) & 0.003861 & square mile $\left(\mathrm{mi}^{2}\right)$ \\
\hline square kilometer $\left(\mathrm{km}^{2}\right)$ & 0.3861 & square mile $\left(\mathrm{mi}^{2}\right)$ \\
\hline \multicolumn{3}{|c|}{ Volume } \\
\hline cubic centimeter $\left(\mathrm{cm}^{3}\right)$ & 0.06102 & cubic inch $\left(\mathrm{in}^{3}\right)$ \\
\hline cubic decimeter $\left(\mathrm{dm}^{3}\right)$ & 61.02 & cubic inch $\left(\mathrm{in}^{3}\right)$ \\
\hline cubic decimeter $\left(\mathrm{dm}^{3}\right)$ & 0.03531 & cubic foot $\left(\mathrm{ft}^{3}\right)$ \\
\hline cubic meter $\left(\mathrm{m}^{3}\right)$ & 35.31 & cubic foot $\left(\mathrm{ft}^{3}\right)$ \\
\hline cubic meter $\left(\mathrm{m}^{3}\right)$ & 1.308 & cubic yard $\left(\mathrm{yd}^{3}\right)$ \\
\hline cubic kilometer $\left(\mathrm{km}^{3}\right)$ & 0.2399 & cubic mile $\left(\mathrm{mi}^{3}\right)$ \\
\hline cubic meter $\left(\mathrm{m}^{3}\right)$ & 0.0008107 & acre-foot (acre-ft) \\
\hline cubic hectometer $\left(\mathrm{hm}^{3}\right)$ & 810.7 & acre-foot (acre-ft) \\
\hline \multicolumn{3}{|c|}{ Mass } \\
\hline $\operatorname{gram}(\mathrm{g})$ & 0.03527 & ounce, avoirdupois (oz) \\
\hline kilogram (kg) & 2.205 & pound avoirdupois (lb) \\
\hline metric ton $(\mathrm{t})$ & 1.102 & ton, short $[2,000 \mathrm{lb}]$ \\
\hline metric ton $(\mathrm{t})$ & 0.9842 & ton, long [2,240 lb] \\
\hline \multicolumn{3}{|c|}{ Pressure } \\
\hline kilopascal $(\mathrm{kPa})$ & 0.009869 & atmosphere, standard (atm) \\
\hline kilopascal $(\mathrm{kPa})$ & 0.01 & bar \\
\hline \multicolumn{3}{|c|}{ Density } \\
\hline kilogram per cubic meter $\left(\mathrm{kg} / \mathrm{m}^{3}\right)$ & 0.06242 & pound per cubic foot $\left(\mathrm{lb} / \mathrm{ft}^{3}\right)$ \\
\hline gram per cubic centimeter $\left(\mathrm{g} / \mathrm{cm}^{3}\right)$ & 62.4220 & pound per cubic foot $\left(\mathrm{lb} / \mathrm{ft}^{3}\right)$ \\
\hline
\end{tabular}

Temperature in degrees Celsius $\left({ }^{\circ} \mathrm{C}\right)$ may be converted to degrees Fahrenheit ( $\left.{ }^{\circ} \mathrm{F}\right)$ as ${ }^{\circ} \mathrm{F}=\left(1.8 \times{ }^{\circ} \mathrm{C}\right)+32$.

Temperature in degrees Fahrenheit $\left({ }^{\circ} \mathrm{F}\right)$ may be converted to degrees Celsius $\left({ }^{\circ} \mathrm{C}\right)$ as ${ }^{\circ} \mathrm{C}=\left({ }^{\circ} \mathrm{F}-32\right) / 1.8$. 


\section{Datum}

Horizontal coordinate information is referenced to the North American Datum of 1983 (NAD 83).

Altitude, as used in this report, refers to distance above the vertical datum.

\section{Abbreviations}

$\begin{array}{ll}\text { ADGGS } & \text { Alaska Division of Geological \& Geophysical Surveys } \\ \text { AGDB } & \text { Alaska Geochemical Database } \\ \text { AGDB3 } & \text { Alaska Geochemical Database, version } 3 \\ \text { ARDF } & \text { Alaska Resource Data File } \\ \text { GIS } & \text { geographic information system } \\ \text { HUC } & \text { hydrologic unit code } \\ \text { HMC } & \text { heavy-mineral concentrate } \\ \text { NURE } & \text { National Uranium Resource Evaluation } \\ \text { RIRG } & \text { reduced-intrusion-related gold } \\ \text { USGS } & \text { U.S. Geological Survey }\end{array}$




\title{
GIS-Based Identification of Areas that have Resource Potential for Lode Gold in Alaska
}

\author{
By Susan M. Karl, Douglas C. Kreiner, George N.D. Case, Keith A. Labay, Nora B. Shew, Matthew Granitto, \\ Bronwen Wang, and Eric D. Anderson
}

Abstract

Several comprehensive, data-driven geographic information system (GIS) analyses were conducted to assess prospectivity for lode gold in Alaska. These analyses use available geospatial datasets of lithologic, geochemical, mineral occurrence, and geophysical data to build models for recognizing different types of gold deposits within physiographic units defined by stream drainage basins that are approximately 100 square kilometers in area. The analytical methods successfully delineated areas in the State that contain known lode gold deposits and occurrences, providing some measure of confidence in their ability to predict gold prospectivity in areas of unknown lode gold potential. The results of our analyses indicate high prospectivity in a few areas scattered around the State that are not known to contain lode gold deposits.

In addition to assessing the potential for lode gold deposits in Alaska, we designed analyses to distinguish different lode gold deposit types, including orogenic, reduced-intrusion-related, epithermal, and gold-bearing porphyry. These can primarily be differentiated using their unique trace element geochemical fingerprints and elemental enrichments, which reflect the characteristics of the geologic environment and chemistry of the ore-forming fluids. We identified multiple parameters that would discriminate the different types of gold deposits, but owing to the limits of available data, the compositional similarity of ore-forming fluids among some types of lode gold deposits, and overlapping geologic environments, distinguishing deposit types at the state scale in Alaska remains problematic. These limitations resulted in overlapping areas of prospectivity for different deposit types, highlighting the challenges for targeted gold exploration in Alaska. Adjustment of some scoring parameters and recharacterization at smaller scales to highlight individual mineral systems for application of prospectivity analyses may be helpful at a district scale. At a regional scale, the aerial overlap of individual deposit type analyses reinforces confidence in prospectivity for a lode gold resource in a drainage basin. Our analysis for undivided lode gold deposits will be the most practical analysis for landuse decisions in which delineation of areas that have confident potential for gold deposits in general is the primary goal.
Data-driven GIS analysis for lode gold potential in Alaska, although limited by the size and uneven coverage of available datasets, objectively indicates prospectivity in areas where exposure is good as well as in areas under cover. The results of our analyses show medium to high prospectivity in areas that surround known deposits, indicating an overall expansion of areas that have the potential to contain gold deposits. Exploration in these areas may help improve the balance between the volume of gold produced in placer districts statewide and the relatively low volume of identified lode resources that contribute to these placer deposits. The results of our analyses can help focus future investigations in areas that show prospectivity but are not known to contain gold deposits, as well as in areas where data are lacking and the geology is poorly understood, and acquisition of additional data may help better define and constrain gold prospectivity.

\section{Introduction}

Gold is a primary commodity that is mined from both lode and placer deposits in Alaska. Exploration strategies for finding gold deposits commonly focus on a deposit type that geologists expect to find in a region. This expectation is based on regional geology, known occurrences, and possibly a regional geochemical survey. In Alaska, handicaps to the determination of gold resource potential include covered or poorly understood geology in many areas, clustering of known occurrences in areas that have more robust infrastructure, and ambiguous data from available geochemical and geophysical surveys.

A geographic information system (GIS) data-driven analysis of the potential and relative certainty for lode gold occurrences was conducted to assess prospectivity in Alaska, including areas under ice, snow, or vegetative cover that have unknown mineral potential; areas underlain by favorable geology; and areas that have known occurrences. The analysis combines multiple data layers to evaluate the geologic setting, rock types, minerals, pathfinder element enrichments, and geophysical favorability of areas defined geographically by drainage basins statewide with respect to a potential concentration of gold. 
Our first-order analysis was to identify potential for any type of lode gold deposit, which we refer to as undivided lode gold deposits. Our second-order analyses attempted to target specific gold deposit types to (1) achieve a tighter spatial constraint of prospectivity relative to that of undivided lode gold deposits, (2) apply specific parameters to assist in focusing future exploration for gold, and (3) more precisely define potential for gold deposits in covered areas. In addition, owing to the correlation of deposit types with distinct tectonic settings, the inferred distribution of a deposit type resulting from prospectivity analysis in an area of poor exposure and unknown geology may serendipitously contribute to knowledge of regional geologic settings and tectonic belts.

\section{Purpose and Scope}

Lode gold was chosen for evaluation in the analyses herein because it is a major focus for exploration and development in Alaska, and important to Alaska's economy. The potential distribution of resources such as gold must be evaluated to aid land stewardship decisions. The data-driven GIS analyses employed herein allow the relative potential for gold concentration to be considered objectively with respect to various possible land uses and integrated with other types of geospatial data to inform land use decisions from local and regional perspectives.

The GIS analytical method used in our analyses was designed to identify areas with geologic potential for lode gold, both known and undiscovered, in Alaska. It is not a comprehensive review of known mines, prospects, occurrences, or mineral deposits that contain gold in the State. Instead, it is an evaluation of where in Alaska lode gold deposits might occur based on geoscientific data, including geology (for example, lithology, mineralogy, known prospects), geochemistry (of rock and sediment samples), and geophysical properties. Comparison of lode and placer deposit records in the Alaska Resource Data File (ARDF, https://ardf.wr.usgs.gov/; U.S. Geological Survey, undated) indicates that as much as two-thirds of the recognized placer deposits do not have associated lode sources or sources of a size comparable to the volume of production from a placer mine or district. This indicates a high potential for discovery of previously unrecognized lode deposits, and our integrated data analyses can contribute to this exploration.

In addition to evaluating the potential for lode gold deposits, more nuanced construction of data models can be applied for guiding exploration for specific types of gold deposits such as orogenic, intrusion-related, gold-bearing porphyries, and epithermal gold. Accordingly, although our primary analysis in this report involves compiling and scoring parameters to identify potential for lode gold deposits statewide, undivided with respect to deposit type, subsequent analyses focus on specific deposit types to facilitate increased efficiency in gold exploration. We attempt to determine discriminating factors in gold systems that sometimes form in distinct circumstances. Deposit-specific parameters can be weighted according to their relative importance in characterizing a deposit. However, because gold deposits can form by complicated genetic processes or by discrete events that overlap in space and time, it may be difficult to discriminate different deposit types. We discuss the benefits and cautions in the application of available datasets at the state scale for digitally analyzing the potential for various types of gold deposits and how to improve and complement these datasets for future analyses.

The methods used here are applicable to other deposit types and other commodities. Publicly available digital datasets contain geologic information that can be used to characterize most deposit types and groups, although available data may not be adequate to discriminate between all deposit types within a deposit group. The evaluation of some deposit types in Alaska can be limited owing to the reconnaissance level of geologic mapping and the lack of available geochemical and geophysical data, information that could provide sufficient detail to target specific deposit types within a group of related deposits. At a district scale where appropriate data are available, deposit-specific tailored analyses can be very effective.

Exploration strategies may focus on gold systems which are high-grade, low-tonnage, structurally controlled, bonanzatype vein systems or they may target large-tonnage, disseminated, and relatively low grade deposits. For applications such as land-use management, regulation, and planning, it may be important simply to know whether there is potential for significant gold resources in an area of interest, regardless of the attributes of the system. To address overall prospectivity for lode gold deposits statewide, we combined the key parameters for all gold deposit types to derive a map showing the potential for undivided lode gold deposits in Alaska. To address exploration strategies for specific types of gold deposits, we created individual maps that show prospectivity for the main types of lode gold deposits that are known or likely to occur in Alaska.

\section{Lode Gold Deposit Definition and Classification}

Lode gold deposits are concentrations of gold that occur as native gold and (or) are concentrated in gold-bearing minerals in rocks. Numerous magmatic and tectonic settings are amenable to the formation of lode gold deposits and result in a variety of deposit types.

The main requirements for gold mineralization are a metal source, mobilization of hydrothermal fluids that carry gold, and a physical or chemical trap to induce gold deposition. Discrimination of and exploration for various hydrothermal systems that may have carried gold rely on a detailed understanding of fundamental geologic and geochemical processes operating in various geologic environments, available sources of fluids, host rock compositions, and potential traps. Lithologic, geochemical, and geophysical data provide critical clues for discerning these processes and environments as well as for guiding exploration and resource assessments. Placer gold deposits are an important spatial clue; they extend across large areas of Alaska but most of them lack known lode sources. These areas cover a variety of geologic settings, implying a corresponding variety in the types of lode sources for the placers. 
The broadest classification of lode gold occurrences falls into four main types of deposits: (1) orogenic (or mesothermal) veins, (2) magmatic-hydrothermal (or intrusionrelated), (3) terrestrial hydrothermal (or epithermal vein) systems, and (4) disseminated sediment-hosted gold. The primary lode gold deposit types, which are listed with their primary global and Alaskan examples, are compiled in table 1. Some well-known Alaskan deposits, including the Pogo mine and the Donlin Creek prospect, are not listed on table 1 because classification of their deposit type is highly debated. Deposits of disseminated sediment-hosted gold, such as the well-known Carlin trend in the State of Nevada, form in continental extensional settings and no analogs are known in Alaska. Based on the current understanding of this deposit type and regional geology, it is not considered likely to be found in Alaska, and so was not addressed in our individual deposit-type analyses.

The three types of gold systems we investigated for Alaska form in relatively distinct geologic environments, with internal variations that reflect the local geologic environment. We briefly introduce the three main deposit types below and describe their characteristics in detail in subsequent chapters where the characteristics are used to build scoring strategies for distinguishing them in our GIS analyses.

\section{Orogenic Gold Deposits}

Orogenic gold systems typically form in metamorphic rocks during the late stages of orogenic collisional events between geologic terranes. Orogenic systems may be hosted in accreted terranes, arc and back arc settings, and craton margin settings (table 1). Large orogenic lode gold deposits are most commonly found in rocks metamorphosed during regional orogenic events (Goldfarb and others, 2001). The most likely geologic settings to host orogenic gold deposits in Alaska are (1) greenschist facies metamorphic belts associated with Phanerozoic suture zones that involve crustal thickening and exhumation to shallower structural levels during progression of the orogenic episode, and (2) accretionary complexes overprinted by thermal anomalies associated with the subduction of oceanic spreading centers or other sources of high heat flow as well as the generation of hydrothermal fluids and melts (Goldfarb and others, 1997; 2001; 2005). Orogenic gold deposits are addressed in chapter 2.

\section{Intrusion-related Gold Deposits}

Gold deposits found within intrusive rocks and associated with intrusive rocks in late-stage dikes, veins, greisens, and disseminations in adjacent host rocks are classified as intrusionrelated gold deposits. Intrusion-related gold deposits are lowgrade, large-tonnage deposits that are zoned around a causative intrusion that has unique geologic characteristics. Intrusionrelated deposits may be hosted in calc-alkaline arcs and in structurally thickened areas inboard of arc settings (table 1). The intrusion-related gold deposits are classified by their association with high oxidation state systems or reduced systems. In large regions of central Alaska and Yukon, economic concentrations of gold in intrusive rocks are mainly associated with reduced or ilmenite-series systems (Thompson and Newberry, 2000; Hart and others, 2004a; Hart, 2007). Owing to the importance of this association, we conducted a GIS analysis to evaluate the prospectivity for reduced-intrusion-related gold (RIRG) in chapter 3. Porphyry copper (such as the Pebble deposit in Alaska) and other high oxidation state, or magnetite-series intrusive systems, may carry large amounts of gold, and these systems are addressed separately in chapter 6 .

\section{Epithermal Gold Deposits}

Epithermal vein systems form in the uppermost crust $(<2$ kilometers $[\mathrm{km}])$ in areas of magmatic activity and may form in alkaline and calc-alkaline arc settings as well as back arc and continental rift settings (table 1). They are typically found in or beneath coeval volcanic rocks. Epithermal vein systems may host precious and (or) base metal ores, although most production is focused on gold and silver. Preservation is a important issue with epithermal deposits, as many are often subjected to mechanical denudation, skewing identified systems to young volcanic arcs. Epithermal deposits globally are most common on the Pacific Rim and are Tertiary or younger in age (Simmons and others, 2005). Metamorphosed deposits of the epithermal clan may be found in terrains where tectonic burial has preserved the high-level volcanic edifices that host the systems. Metamorphosed deposits may have been buried and re-exposed following tectonic uplift or mechanical weathering. Epithermal deposits are addressed in chapter 4.

The deposit types in table 1 can primarily be differentiated with respect to their unique trace element geochemical fingerprints and elemental enrichments, which ultimately reflect the characteristics of the geologic environment and chemistry of the ore-forming fluids. We attempted to define multiple parameters that would discriminate these three types of deposits, but owing to reconnaissance-scale understanding of source rock and host rock types, overlapping geologic environments, incompleteness of trace element geochemical data, and compositional similarity of ore forming fluids among some types of lode gold deposits, differentiating deposit types at the state scale in Alaska is problematic. For example, the overlap of features in the gold-bearing porphyry environment and epithermal systems can result in the inadvertent inclusion of Au-rich porphyry $\mathrm{Cu}(-\mathrm{Mo}-\mathrm{Au})$ systems in the epithermal model. Owing to such challenges, we subsequently chose to analyze gold ore systems. We placed porphyry and epithermal systems into one gold ore-system prospectivity model, reduced intrusion-related gold and orogenic systems into a second prospectivity model, and refined prospectivity strategies accordingly. This combination of deposit types with respect to ore-forming processes enabled us to more precisely identify areas that are expansions of known gold belts and new areas in the State that show potential for containing lode gold deposits. 


\section{Data Types and Analytical Process}

We identified the key characteristics of gold deposit types that are retrievable from available datasets and scored geospatially qualified data with respect to relative importance for indicating the potential for resource occurrence using GIS analysis. To evaluate resource potential across the landscape (Fortescue, 1992), we chose drainage basins as our unit of analysis and selected the smallest drainage basins available in the National Hydrography dataset (http://nhd.usgs.gov/), designated as 12-digit hydrologic unit codes (HUCs), each of which covers approximately $100 \mathrm{~km}^{2}$. Our GIS analysis could alternatively be applied to a different areal unit of evaluation, such as a square mile grid. However, data density sufficient to evaluate by a square mile grid is rare in Alaska and is typically available only for selected, relatively small areas of interest, which could introduce local bias in a regional analysis. Because sediment geochemistry is our most regionally robust dataset, sediment sources are the key target for resource analysis, and therefore drainage basins are the most logical and efficient unit for evaluation in our analyses.

The geospatial datasets assembled for analysis using ArcGIS include (1) bedrock geology from the digital geologic map of Alaska (Wilson and others, 2015); (2) known mineral deposits and occurrences in the Alaska Resource Data File (ARDF, https://ardf.wr.usgs.gov/; U.S. Geological Survey, undated); (3) geochemical data for rock, sediment, soil, and heavy-mineral concentrate (HMC) samples from the Alaska Geochemical Database (AGDB; Granitto and others, 2013, 2019); and (4) the digital aeromagnetic map of Alaska (Saltus and Simmons, 1997; https://mrdata.usgs.gov/airborne/map. html; https://mrdata.usgs.gov/general/map-ak.html).

A data scoring and ranking process for each data type was tailored to critical parameters for each lode gold deposit type described above. For each analysis, data types were chosen and ranked according to their ability to objectively and uniquely define a deposit type; data types were scored according to their relevance to the deposit type and weighted according to their ability to discriminate that deposit type. Associated tables indicate the datasets that were applied in the analysis for each deposit type, the parameters in the datasets that were chosen, and the weighting of each parameter (tables 2-13); a complete summary is given in table 14. Appendixes 1-3 provide information used to select and weight parameters that contributed to the scoring results (Karl and others, 2021) for each deposit type. The scores for each parameter were statistically analyzed and combined using a Python script to yield a total score for resource potential for each HUC. The percentages of the total score that each parameter contributed to each HUC are tabulated in Karl and others (2021). ArcGIS permits users to analyze and query the findings in a spatial context (individual HUCs) on each of the final digital map products (plates 1-9). Users can manipulate parameters and scoring with a Python script in ArcGIS to test for different attributes if they wish to attempt additional analyses at a regional, district, or local scale.
In this report, potential mineral resource is defined as the potential for the occurrence of a concentration of a mineral resource, in this case gold. It does not imply potential for economically viable development or extraction of the mineral resource. This study separates four levels of mineral resource potential using natural statistical breaks, qualified by the certainty of the analysis based on the presence and abundance of favorable attributes for each deposit type. The product of the analysis is a map for each deposit group which indicates the relative level (High, Medium, Low, Unknown) of resource potential, and the relative level (High, Medium, Low, Unknown) of the certainty of the specific deposit type for all of the 12-digit HUCs within Alaska (plates 1-9).

In accord with previous work (Taylor and Steven, 1983; Goudarzi, 1984) and as defined below, the four levels (High, Medium, Low, and Unknown) of resource potential are assigned in our analyses as follows:

1. High mineral resource potential is assigned to areas where geologic, mineralogic, geochemical, mineral occurrence, and geophysical characteristics indicate a geologic environment favorable for resource occurrence; where interpretations of data indicate a high degree of likelihood for resource accumulation; where data indicating the presence of resources support mineral deposit models; and where evidence indicates that mineral concentration has taken place. Resources or deposits need not be previously identified for an area to be assigned high resource potential.

2. Medium mineral resource potential is assigned to areas where geologic, mineralogic, geochemical, mineral occurrence, and geophysical characteristics indicate a geologic environment favorable for resource occurrence; where interpretations of data indicate a reasonable likelihood of resource accumulation; and where an application of mineral deposit models indicates favorable ground for concentration of the specified type(s) of minerals.

3. Low mineral resource potential is assigned to areas where geologic, mineralogic, geochemical, mineral occurrence, and geophysical characteristics define a geologic environment in which the existence of the specific resource is unlikely.

4. Unknown mineral resource potential is assigned to areas where information is inadequate to assign High, Medium, or Low levels of resource potential.

In accord with previous work (Taylor and Steven, 1983; Goudarzi, 1984), the four levels (High, Medium, Low, and Unknown) of certainty are assigned as follows:

1. High certainty is assigned to areas for which available information from multiple sources provides a robust indication of the level of mineral resource potential.

2. Medium certainty is assigned to areas for which available information is sufficient to give a reasonable indication of the level of mineral resource potential. 
3. Low certainty is assigned to areas for which available information is limited and only indicates a level of mineral resource potential.

4. Unknown certainty is assigned to areas for which available information is not adequate for determination of the level of mineral resource potential.

For the GIS analyses in this report, certainty for each HUC is quantified by the number of geoscientific data layers that contribute to the resource potential score of that HUC. A lack of sediment, HMC, or rock geochemical samples, as well as a lack of appropriate rock type and ARDF records for a HUC yields an Unknown classification assignment. If aeromagnetic data are the only data that exist for a HUC, they are not counted towards a certainty calculation because their utility stems from their coordination with a specific rock type. The potential-certainty tables that are calculated based on five datasets (tables 3,5) are those for which magnetic character cannot be tied to potential for lode gold occurrences. The potential-certainty tables that are calculated based on six datasets (tables 7, 9, 11, 13) are those for which the magnetic character of a specific rock type can be an indicator of potential for lode gold occurrences associated with that rock type. This method is easily adaptable to other groups of deposit types, although available data may not be adequate to discriminate between some deposit types. For example, important parameters for gold deposits - hydrothermal alteration type and intensity - are poorly documented statewide and undeniably limit the precision of our results for all deposit types. Datasets applied for the lode gold analyses are discussed below.

\section{National Hydrography Dataset and Watershed Boundary Dataset}

The National Hydrography and Watershed Boundary Datasets (http://nhd.usgs.gov/) delineate surface water networks and drainage basins throughout the United States using standardized criteria based on topography and hydrology. Relative drainage basin size, geographic location, and nested hierarchy are encoded within a string of digits known as a hydrologic unit code, or HUC. A classical hydrologic unit is a division of a watershed with a single discharging stream; accordingly, it corresponds to a physical watershed that is defined by topography. These HUCs are identified by 2 to 12 digits, which correspond to the largest drainage systems known as regions and to subwatersheds, respectively. Numeric codes, names, and boundaries associated with each HUC provide unique identifiers useful for associating other geospatial data from multiple sources in a GIS. We use the term "HUC" to refer to a physical drainage subbasin and not solely to the string of digits used to identify the subwatershed. Twelve-digit HUC boundaries are used in this study as a geographic reference frame and sampling unit for evaluating mineral resource potential across Alaska. In Alaska, the majority of 12-digit HUCs are classical HUCs, subwatersheds that refer to single streams; some 12-digit HUCs refer to subdivisions of large drainages. The datasets described below were scored for application to each 12-digit HUC across the State as they pertained to specific gold deposit types, and scores were statistically analyzed and classified for mineral resource favorability following the methods described below.

\section{Geochemical Data Sources}

The rock and sediment geochemical datasets used are compilations of data from the Alaska Geochemical Database, version 3.0 (AGDB3, Granitto and others, 2019). The AGDB3 is a compilation of (1) U.S. Geological Survey (USGS) geochemical analyses of rock, sediment, soil, and HMC samples that were collected between 1962 and 2017 from Alaska and prepared according to various USGS standard methods (Miesch, 1976; Arbogast, 1990, 1996; Taggart, 2002); (2) reanalyses of 1,121 archived USGS rock samples from the National Uranium Resource Evaluation (NURE), the Alaska Division of Geological \& Geophysical Surveys, and the Bureau of Land Management using higher precision modern analytical technology and complementary data; and (3) legacy data from the Bureau of Mines.

The NURE database contains data from the NURE Hydrogeochemical and Stream Sediment Reconnaissance (NURE-HSSR) program that was overseen by the U.S. Atomic Energy Commission (Smith and others, 2013). The 66,103 NURE sediment samples were collected in Alaska between 1976 and 1979 and analyzed by Los Alamos National Laboratory; 65,993 of these Alaska sediment samples were reanalyzed for additional elements for application in the Alaska Mineral Resource Assessment Program.

The Alaska Division of Geological \& Geophysical Survey's (ADGGS) geochemical database includes analyses of 12,437 rock samples, 10,919 sediment samples, 100 soil samples, and 1,568 HMC samples collected between 1960 and 2014. These data provided by the ADGGS are also available for download via the internet (http://doi.org/10.14509/geochem).

The file structure and data format of each database is different. Reformatting was necessary to ensure consistency of data presentation and to facilitate use in the prospectivity analysis. The AGDB3 used for our analyses in this report contains data for 129,347 rock samples (including mineralized samples), which include 56,112 igneous rock samples, 40,194 metamorphic rock samples, 19,012 sedimentary rock samples, and 14,029 unspecified rock samples, as well as 169,606 sediment samples, 51,518 HMC samples, 18,137 pan mineralogy samples, and 6,969 soil samples.

\section{Sediment Geochemical Data}

The sediment geochemical data compose the most comprehensive, evenly distributed, and highest-density dataset applicable to the analysis of mineral resource potential across Alaska. This dataset is referred to in this report as sediment 
geochemistry because, although more than 80 percent of the sediment samples in the AGDB3 were collected from streams, sediment samples collected from other types of surface-water bodies such as lakes, ponds, and bays are also included. The sediment dataset is particularly useful owing to concealment of bedrock in many areas by unconsolidated sediment and vegetation. Sediment geochemical data portray elemental abundance patterns that reflect rock compositions in their respective drainage basins and thus provide clues about rock types and mineral occurrences in areas of poor exposure or where geologic mapping is lacking.

Sediment geochemical data from the AGDB3 include heterogeneous data of highly variable accuracy, precision, and associated lower detection limits. Although analytical methods have greatly improved in recent years, many geochemically scarce elements have highly left-censored data (assigned minimum values) resulting from high minimum detection limits for older analytical data. In addition, analyses of many samples in the AGDB3 database were completed by more than one analytical method, including many archived sediment samples that have been reanalyzed using newer technology. To minimize the complexity inherent in multiple determinations for individual elements, a single best value concentration, derived from the consideration of sample preparation and sample analysis methods, was identified for each element in each sample. Granitto and others (2013) provide a detailed description of the ranking criteria accompanying analytical methods and how they were used to determine the so-called best value for each sample. For our GIS-based analyses, in situations for which more than one sample was analyzed from a specific sample location, the highest best value for any given element from that location was selected for use in calculation of geochemical scores, to display on point plots, and to use for gridded map layers.

In addition to the best-value determinations of chemical values with respect to analytical methods, the comparability of data was compromised by a lack of consistency among analytical methods for the determination of elemental abundances. For example, different analytical techniques have different detection limits for a single element, thus resulting in diverse data-censoring limits. Censored data are those that fall outside the detection limit for a specific element analyzed by a particular method. Censored values complicate the determination of summary statistics, such as the mean, median, standard deviation, and percentile values, which are commonly used to determine threshold values for a dataset. Two strategies were used for handling the censored data when calculating the summary statistics for the elements in the combined sediment dataset used in previous studies (Karl and others, 2016; Lee and others, 2016): (1) when 40 percent or less of the data were censored, either one-half the minimum noncensored value or one-half the minimum lower detection limit (whichever was smaller) was substituted for the censored data, prior to the calculation of the element's summary statistics; or (2) when the data were more than 40 percent censored, the Kaplan-Meier method (Kaplan and Meier, 1958; Helsel, 2012) was used to estimate the summary statistics.
Threshold values used to define anomalously enriched element classes in mineral prospectivity analysis can be set in various ways. One of the more common methods is to use a percentile value, which will always yield anomalous element classes with respect to the dataset. The anomalous element classes, however, may not be enriched beyond the background concentrations of the material investigated, and thus not reflective of the potential for a mineral deposit. To avoid this pitfall, we instead calculated levels above background for this study. For the sediment dataset in our analyses, the median value of elements in the combined sediment database of Lee and others (2016) is used for determining the background concentrations. Classification ranges for the elements were chosen on a pseudologarithmic scale based on multiples of the respective background concentrations and provided in appendix 1; background was determined to be 0.5 to 1.5 times the median value, values in samples at 1.5 to 3.5 times background are considered as weakly anomalous, 3.5 to 7.5 times background are moderately anomalous, 7.5 to 15.5 times background are highly anomalous, and values $>15.5$ times background are extremely anomalous.

\section{Rock Geochemical Data}

Rock geochemical data provide important clues for revealing the potential of rocks in a HUC to contain an element or mineral concentration. The distribution of rock geochemical analyses for Alaska is widely scattered, and although the dataset is less robust when compared to the distribution of sediment data statewide, it is a valuable and strongly weighted parameter in our analyses. This study did not attempt to classify rock types based on the geochemical characteristics of rocks, given the wide range of associated host and source rocks in gold-dominant hydrothermal systems. Instead, we focused on the use of the key suites of elements in rock samples to aid in the identification of HUCs that have resource potential. All rocks were treated the same, whether they are noted as fresh, altered, or mineralized; however, only a very small percentage of the rock samples that have data reported in AGDB3 were submitted as altered or mineralized.

Many of the rock samples in the AGDB3 have been analyzed for only a limited number of elements, which typically do not include the important gold pathfinder elements such as As, $\mathrm{Bi}, \mathrm{Sb}, \mathrm{Te}, \mathrm{Se}, \mathrm{Tl}$, and $\mathrm{Hg}$. We submitted 1,121 archived rock samples to USGS contract laboratories for reanalysis by modern inductively coupled plasma mass spectrometry following a sinter digest (see Granitto and others, 2019) to acquire concentrations of pathfinder elements for areas of the State where they were lacking. The results of these reanalyses were integrated into AGDB3 and processed to determine best values.

Threshold values for anomalous concentrations of elements in the rock samples were established to identify concentrations of elements that are high compared to typical rock. There are varied methods and approaches to determine threshold values for a rock geochemical dataset. As discussed above for sediment geochemistry, the calculation 
of a percentile value will always produce anomalous element classes with respect to the dataset that may not be enriched beyond the background concentrations of the material investigated, and thus not reflective of the potential for a mineral deposit. Following Smith and others (2013), estimates of average crustal abundances are used as the basis for classifying element enrichments in rocks. Average crustal abundances of elements - also known as the Clarke Index - as determined by Wedepohl (1995), were applied to set background values for rocks in the AGDB3, and they are listed with sources for each element used in our analyses in appendix 1.

Similar to the application of levels of anomaly to sediment data, classification ranges for the elements used from the rock geochemical dataset were chosen on a pseudologarithmic scale based on multiples of the respective background concentrations. Background for the rock dataset was determined to be 0.5 to 1.5 times the crustal average abundance of the element (appendix 1); values in samples at 1.5 to 3.5 times background are considered weakly anomalous, 3.5 to 7.5 times background are moderately anomalous, 7.5 to 15.5 times background are highly anomalous, and values $>15.5$ times background are extremely anomalous.

\section{Heavy Mineral Concentrate Mineral and Geochemical Data}

Although HMC data do not constitute a comprehensive dataset, these samples are important because they can demonstrate the presence of gold- and associated pathfinder mineralbearing rocks in a HUC. The HMC data are divided into two components in the AGDB3: mineralogy and chemistry.

Mineralogic data that are based on visual identifications are available for more than 18,137 nonmagnetic bulk-panned HMC samples in the AGDB3 (Granitto and others, 2019) derived from sediments, soils, or rocks, but most of the data are from the nonmagnetic fraction (C3) from panned stream sediments. These data were obtained from data-entry sheets, USGS Open-File Reports, and archival digital spreadsheets. The entries include several categories of heavy-mineral abundances. Grain-count data are available for some samples. Abundances in other samples are described by a variety of qualitative values (for example, present, trace, and abundant), estimated percentages, or percentage ranges. Null values indicate that the mineral was not observed in a sample. Mineralogy data in the AGDB3 are presented as they were originally recorded and interpreted; data sources are listed in Granitto and others $(2011,2013,2019)$. The estimates of relative amounts of identified minerals (from trace to abundant) for samples were not factored into the scoring process owing to the qualitative nature of values and the incomplete assignment of values in the dataset. Points were assigned simply for the reported presence of a relevant mineral. We augmented the HMC mineralogical dataset in the AGDB3 by adding known placer deposits, derived from the Alaska Resource Data File, as locations demonstrated to contain gold in sediments.
The AGDB3 dataset contains best-value geochemical data for 49,950 HMC samples. Of these HMC samples, 73.6 percent are from the nonmagnetic (C3) fraction, 13.8 percent are from the bulk concentrate fraction (mostly panned), 7.8 percent from are the magnetic $(\mathrm{C} 1)$ fraction, 2.3 percent are from the combined weakly magnetic/paramagnetic and nonmagnetic (C4) fractions, and 2.2 percent are the weakly magnetic/paramagnetic $(\mathrm{C} 2)$ fraction. The specific methods used to incorporate HMC mineralogy and (or) geochemistry into our analysis of mineral resource potential are more fully described in the appropriate sections below.

\section{Alaska Resource Data File}

The ARDF contains more than 7,700 records of lode and placer mines, prospects, and mineral occurrences in Alaska. USGS Open-File Reports containing ARDF records for each USGS 1:250,000-scale quadrangle are available for download separately or as part of a single composite ARDF database (from https://ardf.wr.usgs.gov/; U.S. Geological Survey, undated). ARDF records include a broad spectrum of mineral deposit types. For this study, mineral deposits are localities that have reported inventory or past production, whereas mineral prospects and occurrences describe localities where minerals of the commodity are known but have no reported inventory.

For each specific lode gold deposit type, a list of searchable keywords was developed for pertinent ARDF record fields to identify records that might indicate the presence of that deposit type. Keywords were weighted by 1 to 6 points for their relevance to the targeted mineral deposit type. In some cases, keywords were assigned negative scores as low as -5 when indicative of geological systems known to be unassociated with the gold deposit type of interest. For each deposit type in the ARDF, complete lists of keywords and associated scoring weights are listed in appendix 2 and some of the highest scoring keywords are summarized in table 14. Placer deposits were excluded from the ARDF keyword score for a HUC to restrict the search to lode deposits. However, placer deposits are a strong indicator of a lode source within their drainage basin; in our analyses, placer deposits were treated as locations of HMC samples and combined with the HMC dataset.

In some cases, scrutiny of individual ARDF records revealed misspellings and imprecise location information that hindered the scoring of keywords. Records that contained identified errors were corrected in the database prior to the final prospectivity analyses. ARDF records are updated on a regular basis, but caution is advised because the database may still contain unrecognized errors that might compromise keyword searches. The preponderance of accurate ARDF records and other data used will likely outweigh or counteract spurious ARDF records. Although the inclusion of some anomalous sediment or soil samples as localities in the ARDF database can result in a double-scoring effect, this effect is minimal because these records generally lack detail other than commodities or ore minerals and cannot receive high scores for the ARDF parameter. 
Keywords and scoring parameters for fields in the database were calibrated using known examples of each deposit type as detailed in ARDF records. Some keywords were searched in multiple fields to account for inconsistent usage in the ARDF data fields. Scores for each of the fields in the ARDF are additive for each record. In HUCs that contain multiple relevant ARDF records, scores for the ARDF records were not aggregated; only the highest scoring record in a HUC was applied. Total scores were statistically analyzed by the Jenks (1967) method to bin into groups with increasing levels of potential. The ARDF scores were accordingly assigned a score of 5 for high potential, 3 for medium potential, and 1 for low potential in the scoring tables $2,4,6,8,10$, and 12 for all the deposit models addressed in this report. The maximum possible score was limited to 5 to prevent known deposits from skewing the spatial distribution of deposit potential. This allowed other parameters such as rock type, geochemistry, and mineralogic data more weight to help identify undiscovered lode gold deposits.

In our initial exercises, a custom Python script in ArcGIS was used to search all ARDF records for matches in the (1) undivided, (2) orogenic, (3) reduced intrusion-related, and (4) epithermal keyword lists (appendix 2), and to assign the records a total score for these deposit types. After GIS analysis demonstrated significant overlap in the distribution of potential for these three deposit types, scoring of keywords was modified to attempt distinction of lode gold deposits with respect to two deposit groups that reflect different fundamental genetic processes: (1) gold-bearing porphyry and epithermal ore systems, and (2) reduced intrusion-related and orogenic ore systems. Specific deposit group analyses described below provide more details of how ARDF scores were implemented to assess mineral potential.

\section{Geologic Map of Alaska}

The digital geologic map of Alaska (Wilson and others, 2015) portrays the distribution of diverse rock types across the State. The catalog of lithology descriptions in the table "nsalith" of the geologic map geodatabase was searched to identify rock types most prospective as sources and (or) best suited for hosting specific deposit types. Lithology query results were used to develop derivative, generalized lithology map layers that show the distribution of rock types favorable for the occurrence of each lode gold deposit group across Alaska. The rationale for points assigned to lithologies considered favorable for the occurrence of each deposit type are described in detail below, listed in scoring tables $2,4,6,8,10$, and 12 , and summarized in appendix 3 .

\section{Aerial Magnetic Survey Data}

Geophysical data, including aerial magnetic survey data, are a first-order tool for understanding geology and the distribution of rock types in a survey area. Magnetic values in aerial magnetic surveys can be used to distinguish rock types that contain magnetic minerals from those that lack them geospatially, and such magnetic contrasts can define contacts and major structures. The presence or absence of magnetic rocks is not a direct proxy for the presence of gold but can be useful, for example, to identify magnetite-bearing versus ilmenitebearing intrusive rocks that have potential for hosting different types of gold deposits.

A compilation of aeromagnetic data for the State of Alaska (Saltus and Simmons, 1997; Connard and others, 1999; https://mrdata.usgs.gov/general/map-ak.html) was used in the analyses. The total magnetic intensity (after removing International Geomagnetic Reference Field values) has a grid cell spacing of 1,000 meters (m); magnetic field observations are continued to a common datum of $305 \mathrm{~m}$ above the topography (Blakely, 1995). A tilt derivative, defined as the arctangent of the ratio of the first vertical derivative of the potential field to the horizontal gradient of the field, was applied to the total magnetic intensity data to enhance causative sources (Miller and Singh, 1994; Verduzco and others 2004; Anderson and others, 2017). The values that resulted from the application of these filters to the aeromagnetic dataset were geospatially correlated with rock types derived from the nsalith database in the digital map of Alaska (Wilson and others, 2015).

The aeromagnetic dataset was not used in analyses for deposit types, such as orogenic gold, that are not derived from magmatic systems. The aeromagnetic dataset also was not used for the analysis of gold resource potential in undivided deposit types, because both magnetic and nonmagnetic rocks can host lode gold deposits and discrimination of specific deposit types was not appropriate for that exercise. Our GIS analyses for intrusion-related, lode gold deposit types target specific models that are associated either with oxidized magnetiteseries granitoids or with reduced ilmenite-series granitoids, and we used the aeromagnetic data layer for models addressing gold-bearing systems genetically related to intrusive rocks. The filtered aeromagnetic layer provided values only for mapped granitoid and hypabyssal rocks on the digital map of Alaska for the pertinent analyses. In this magnetic data subset, granitoid rocks that have positive values are interpreted to be magnetiteseries intrusive rocks and rocks that have negative values are interpreted to be ilmenite-series intrusive rocks. A HUC may contain both types of granitoids and therefore might receive a magnetic dataset score in more than one model. Sparse geochronologic control precluded compensation for rocks that might have acquired their signature during a magnetic reversal. Aeromagnetic data thus have limited utility for regional analysis of lode gold resource potential but may have important practical utility for identifying host rocks that have gold potential at a district or deposit scale.

\section{GIS-Based Methods}

In the GIS methods applied for our prospectivity analyses, key quantifiable characteristics of the main, conventionally recognized gold deposit types were identified in available datasets and scored with respect to importance for indicating gold resource potential. A data scoring and ranking process was 
tailored to critical parameters for three lode gold deposit types, two lode gold system types, and one overarching undivided deposit group. Associated tables indicate which datasets were used in the analysis for each deposit type, which parameters in the datasets were queried, and the amount each parameter contributed to the estimate of deposit type prospectivity in each HUC (tables 2-14). Appendixes 1-3 and geospatial data file sources (see Data Resources, this report) provide the scoring criteria for each dataset; the information and data permit users to analyze and query the findings in a spatial context on each of the final digital map products. We used a Python script to combine individual parameter scores into cumulative scores for each HUC, which are provided with raw scores from each dataset and their percentage of the cumulative score in Karl and others (2021).

Cumulative total scores achieved from multiple parameters that characterize each of the specific lode gold deposit types were statistically divided into three levels of potential to contain gold using natural statistical breaks (Jenks, 1967) and a fourth category of Unknown potential for HUCs that lack data. The uneven distribution of data can result in scores skewed by the amount of available data. Our method assigns the scores for certainty based on the number of datasets that contribute to each score, a measure of the presence and abundance of favorable attributes for each deposit type or group. The product of the analysis is a map for each deposit group which indicates the relative level (High, Medium, Low) of resource potential, represented by red, yellow, and green colors, respectively, and the relative level (High, Medium, Low) of certainty, represented by dark, medium, and light shades of the colors, respectively, of each deposit type for all 12-digit HUCs in Alaska (plates 1-9). The Unknown class, representing a lack of data, is colored gray on plates $1-5$.

Plate 1 shows the results of statistical division of scores for a general class of undivided lode gold deposits. Results for three main conventional classifications of lode gold deposits (orogenic, intrusion-related, and epithermal) are shown on plates 3,4 , and 5. On these three plates, specific areas in Alaska show similar distributions of red (High potential), yellow (Medium potential), and green (Low potential) colors. In recognition of this overlap, we created an exercise to identify the areas in which the overlap is the most complete, to evaluate the reasons for overlap and implications with respect to (1) our analytical methods, (2) geologic setting, and (3) potential for type and abundance of gold mineralization. The results of this exercise are shown on plate 6 . These results led us to reframe our approach and analyze for gold ore-forming systems. These analyses are shown on plates 7 and 8 ; their overlap evaluation is shown on plate 9 .

\section{Chapter 1. Lode Gold Deposits- Undivided}

The analysis for undivided lode gold deposits in this report is an inclusive analysis of the possible variations of orogenic, intrusion-related, and epithermal deposit types in combination. Exploration that targets specific gold deposit types by emphasizing discrimination of settings and processes for gold mineralization can be time and cost efficient but may not always be possible, practical, or needed. Various specific characteristics, including rock types, minerals, and chemical elements may be present in more than one deposit type or may have gradational ranges between deposit types. In addition, complications to discrimination of distinguishing features include geologic settings and processes favorable for the formation of gold deposits that may overlap in space and time. For example, anatexis in orogenic belts can blur the lines between igneous and metamorphic processes, such as in the Chugach accretionary complex, where gold quartz veins sourced in metasedimentary rocks are spatially associated with the near-trench anatectic plutons (Haeussler and others, 1995). In addition, gradational physical conditions such as temperature and pressure in transitions from deep to shallow levels in magmatic systems may result in modification of features typical of porphyry and epithermal environments such as at Far Southeast Lepanto in the Philippines (Hedenquist and others, 2017). Overlaps in time result from changes in plate motions and tectonic setting, which can initiate new geologic processes that affect a given area. Metal concentrations from an earlier mineralizing event might be remobilized in a later mineralizing event induced by processes in a new and different tectonic setting, such as at the Tasman orogenic belt in southeastern Australia, which contains Early Devonian orogenic deposits at Bendigo, Middle Devonian porphyry-related deposits at Morning Star and Cohen's Reef, and Late Devonian epithermal deposits associated with acid volcanic rocks at Mount Macedon (Phillips and Hughes, 1996). Such complexity may best be accommodated in an analysis of prospectivity for undivided lode gold deposit types.

\section{Deposit Group Characteristics}

The existence of different types of gold deposits stems from the many factors that can affect the genesis and evolution of gold-bearing hydrothermal systems. The primary types of lode gold deposits - orogenic, magmatic-hydrothermal, and terrestrial-hydrothermal/epithermal — have some unique characteristics and some common characteristics. Definitive factors that contribute to the various gold system types include metal source, heat source, temperature, pressure, fluid composition, and oxidation state. Further, mechanisms for transport, concentration, and deposition of gold may have discrete values that help to define deposit types or may have a range of values. Such factors are commonly reflected in the presence of minerals and geochemical elements alone or in various associations. Other geologic factors, such as tectonic setting, host rock composition, and structural controls including metamorphic fabric and fault size and density, affect the geologic environment of gold deposits in locally unique combinations. All factors were included in the scoring parameters for the undivided lode gold deposit model. 


\section{Mineral Resource Potential Estimation Method}

In our analysis for undivided lode gold deposits, a scoring system was devised using the key parameters that identify all the main gold deposit types that are likely to occur in Alaska. The ARDF database provides practical evidence for various types of gold deposits in the State. Recognizing that deposits are often clustered in favorable settings, we chose to limit weighting the scores for known deposits in HUCs to avoid biasing results toward known districts and to test the potential for undiscovered deposits statewide. A variety of rock types can potentially host gold deposits, and lithologic data from the geologic map of Alaska are broadly applicable for the combination of all lode gold deposit types. In contrast to the ARDF records, this dataset is likely to include large areas underlain by a favorable rock type that may or may not be in a favorable geologic setting. Rock and sediment geochemistry are the most robust datasets with respect to even distribution and statewide coverage, and in contrast to ARDF data, are regionally unbiased in terms of locating a concentration of target elements. Consequently, the geochemical datasets carried the dominant weighting in our scoring process. The HMC data are equally important in locating mineralized bedrock, but owing to uneven coverage statewide, carried less weight than rock and sediment geochemistry. Finally, although aeromagnetic data are comprehensive statewide, both magnetic and nonmagnetic rocks host different types of gold deposits, and for this exercise magnetic data have little discriminatory utility at the regional scale. No scores for magnetic values were applied to HUCs for analyzing potential for lode gold, undivided with respect to deposit type.

The maximum possible score for potential for a lode gold deposit within a HUC is 185 points (table 2). If all datasets (except the unscored magnetic dataset) contribute to this score, rock and sediment chemistry can account for as much as 74 percent of that score, HMC data as much as 10 percent, lithologic data a maximum of 13 percent, and the ARDF records as much as 3 percent. The total score for a HUC, statistically binned by the Jenks (1967) method, was used to determine High, Medium, or Low potential. The points and percentages that each dataset contributed to the total score for each HUC can be queried in ArcGIS and are tabulated in Karl and others (2021).

\section{Lithology}

Scoring lithology for the undivided lode gold model encompasses the major favorable rock types from each deposit group. No preference was given to a particular deposit type. We assigned three points each for the presence of felsic to intermediate volcanic, hypabyssal, and plutonic rocks; lamprophyre; metavolcanic or metasedimentary schist; or carbonaceous metasedimentary rocks. Scores were additive; a maximum of 24 points for lithology could be assigned to a HUC (table 2). Application of this dataset contributed one point to the certainty score for each HUC (table 3 ).

\section{Alaska Resource Data File}

For the undivided lode gold model, keywords from the lode gold deposit types described above were included. Placer deposits were excluded. Since this model does not attempt to differentiate between types of lode gold deposits, ubiquitous gold-associated alteration and ore minerals, such as potassium feldspar and pyrite, were given higher weighting for the undivided model than for the individual models described in subsequent chapters (appendix 2). Gold as a keyword was weighted highly in all fields in the ARDF database. Keyword totals were statistically binned and assigned an ARDF score of 1,3 , or 5 points for totals of $26-50,51-83$, and $>83$ points per HUC, respectively (table 2). One point was contributed to the certainty score for each HUC that contained an ARDF record for lode gold (table 3).

\section{Rock and Sediment Geochemical Data}

Elemental enrichments of gold and associated pathfinder elements in rocks at different levels above background from both the rock and sediment geochemical datasets garnered the dominant amount of points in this analysis. Element scores were weighted based on the degree of anomalism of the specific element or element associations relative to background for Alaska sediment data (Smith and others, 2013; Lee and others, 2016), and for rock types globally for the rock geochemical dataset (appendix 1). The scoring rubric is outlined in table 2. Pathfinder elements such as As, $\mathrm{Bi}, \mathrm{W}$, and Te combined with an association of base metal minerals approximate the geochemical signature of orogenic gold systems (for example, Goldfarb and others, 2005). The presence of $\mathrm{Au}, \mathrm{Ag}, \mathrm{Bi}$, and Te with associated $\mathrm{W}, \mathrm{Sb}, \mathrm{Cu}$, or Mo, which contrasts with the emphasis on arsenic and associated base metals for the orogenic model, approximates the signature for reduced intrusion-related gold systems (Lang and Baker, 2001). The presence of gold and key pathfinder elements, including $\mathrm{Ag}, \mathrm{As}, \mathrm{Bi}, \mathrm{Sb}, \mathrm{Hg}, \mathrm{Se}, \mathrm{Tl}$, and Te, approximate the signature for epithermal gold deposits (Simmons and others, 2005). Pathfinder elements for these main gold deposit types were scored with equal weight at 1.5 to $3.5,3.5$ to $7.5,7.5$ to 15.5 , and $>15.5$ times background (appendix 1), and include $\mathrm{Ag}, \mathrm{As}, \mathrm{Bi}, \mathrm{Hg}, \mathrm{Sb}, \mathrm{Se}, \mathrm{Te}$, and Tl. Combinations of bismuth and arsenic at or $>15.5$ times background with $\mathrm{Cu}, \mathrm{Pb}, \mathrm{Zn}, \mathrm{Mo}$, or $\mathrm{W}$ were also scored. The points for gold and pathfinder elements for all rocks sampled in a HUC were additive and could garner a maximum of 66 points for the rock chemistry dataset for a HUC (table 2). The points for gold and the pathfinder elements are additive but limited to the sample with the highest values in a HUC for the sediment database score. The maximum possible score for a HUC for this dataset is 71 points (table 2). Application of rock and sediment data contributed one point each toward the certainty score for a HUC (table 3). 


\section{Heavy Mineral Concentrate Data}

All HUCs received scores for the presence of gold and indicator minerals for all gold deposit types in the HMC dataset, and ARDF records for placer deposits were added to the scoring rubric for heavy minerals (table 2). The presence of gold in a placer deposit in a HUC was recognized with four points. The presence of gold or a gold-bearing mineral in a sample from the heavy mineral concentrate dataset was assigned three points. The presence of indicator minerals including arsenopyrite, bismuth, bismuth oxides, boulangerite, cinnabar, enargite, jamesonite, orpiment, proustite, realgar, silver sulfosalts, stibnite, or tetrahedrite earned two points for a HUC. The presence of indicator minerals including anglesite, cerrusite, chalcopyrite, copper sulfides, copper oxides, galena, molybdenite, marcasite, powellite, scheelite, sphalerite, wolframite, or wulfenite garnered one point for a HUC. Classes of indicator minerals were scored additively for with a maximum possible total of 10 points.

Geochemical analyses of heavy mineral concentrates were also scored additively for $\mathrm{Au}, \mathrm{Ag}, \mathrm{As}, \mathrm{Bi}, \mathrm{Hg}, \mathrm{Sb}, \mathrm{Te}, \mathrm{As}$, or $\mathrm{Bi}$ associated with $\mathrm{Cu}, \mathrm{Pb}$, or $\mathrm{Zn}$, and $\mathrm{Bi}$ associated with $\mathrm{Cu}, \mathrm{Mo}$, or $\mathrm{W}$, reflecting signatures of the orogenic, intrusionrelated, and epithermal models, for a maximum possible total of 9 points (table 2). The maximum number of points for the HMC dataset combined with ARDF placer deposits is 19 points for the combined mineralogy and chemistry. Application of this dataset contributed one point toward the certainty score for a HUC (table 3).

\section{Results and Discussion}

All HUCs across Alaska were scored for the potential to contain lode gold deposits (table 2), and for the confidence, or level of certainty, that these scores indicate prospectivity for gold, based on the number of datasets that contributed to the score of each HUC. As explained in the Data Types and Analytical Process section, these scores were statistically divided at natural breaks using the Jenks (1967) method into High (red), Medium (yellow), and Low (green) classes to show prospectivity, and ranked by the amount of data that contributed to the scores, depicted as dark (High), medium (Medium), or light (Low) shades of those colors to show the level of confidence on plates 1 and 2. The gray shaded HUCs on these plates are areas for which data are lacking and potential for gold is not known.

Geographic features mentioned below with respect to the distribution of gold prospectivity classifications are shown on figure 1; major faults depicted on figure 1 are shown on all plates as georeference aids. Some of the main deposits and occurrences that contain lode gold in Alaska are also shown on all plates for reference. The coincidence of these deposits with red HUCs on plate 1 indicates that our analyses successfully identified known gold deposits in Alaska. ARDF localities that contain lode and placer gold are shown on the same map of prospectivity of undivided lode gold deposits on plate 2. The distribution of ARDF record locations and red HUCs on plate 2 shows that areas in the state have high scores for potential to contain lode gold deposits that do not contain known gold occurrences. At a reconnaissance level, the distribution of light, medium, and dark red HUCs on plate 2 suggest expansion of areas that have high gold prospectivity in the vicinity of known occurrences. A small number of isolated red, high-prospectivity HUCs are not located near known lode and placer gold localities (plate 2); these are areas that warrant further investigation and verification.

\section{Areas that have Known and Newly Recognized Prospectivity for Lode Gold Deposits}

To the first order, the model for undivided lode gold deposits highlights known gold districts in Alaska, including the Nome District (Rock Creek) on the Seward Peninsula, the eastern Brooks Range (Chandalar/Mikado), the Kuskokwim Mountains (Donlin Creek), the Yukon-Tanana uplands (Fort Knox, Pogo), the Alaska Range (Terra, Estelle, Whistler), south-central Alaska (Lucky Shot/Independence, Crow Creek, Cliff) and the Juneau gold belt in southeastern Alaska (Kensington, Alaska-Juneau, Treadwell) (plate 1). Dark red, highprospectivity HUCs are located within belts of medium to dark yellow, medium-prospectivity HUCs (plates 1,2), suggesting that the high scores correspond to regional trends of undetermined gold-bearing deposit types.

Our analysis indicates expanded prospectivity in these areas and indicates a few previously unrecognized areas such as the foothills south of the Kobuk Fault, and under-prospected areas such as the western Alaska Range, that may have potential for gold deposits. These areas are discussed in more detail below.

\section{Northern Alaska}

In northern Alaska, sparse High-potential (red) HUCs correspond well with existing ARDF localities for lode and placer gold (plate 2). These include some scattered HUCs in the western Brooks Range and a larger cluster of HUCs in the southeastern Brooks Range that are along strike with the Mikado Mine (fig. 1; plate 1). These areas are underlain by mainly calcareous and carbonaceous metasedimentary rocks that contain goldbearing quartz veins in a Cretaceous orogenic belt (Moore and others, 1994; Barker and others, 2009). Isolated light and dark red HUCs in the western and northern Brooks Range that have high scores, based mainly on sediment chemistry, do not correlate with lode or placer ARDF localities.

\section{Northwestern Alaska}

On the Seward Peninsula, there is a strong correlation between lode and placer gold ARDF localities and HUCs that are ranked as High and Medium potential for gold deposits. The association of the occurrences on the Seward Peninsula with strongly deformed calcareous and carbonaceous metasedimentary rocks of 
the Nome Complex indicates these deposits may predominantly be orogenic-type deposits. These metamorphosed continental margin rocks are correlated with the metasedimentary rocks in the Brooks Range (Till and others, 2011), but appear to have more gold occurrences than do equivalent rocks in the Brooks Range. High-prospectivity HUCs south of the Kobuk Fault in the Selawik Hills (fig. 1; plates 1,2) lack ARDF localities, and medium to high-prospectivity HUCs correspond to sparse ARDF localities in the Zane Hills (fig. 1; plates 1, 2). These ARDF occurrences are associated with late-stage phases in the upper levels of plutons that intrude a Mesozoic volcanic arc. The light shades of these HUCs suggest their high scores are based mainly on limited, predominantly geochemical data (table 3; Karl and others, 2021). In the Ruby batholith, which extends from the east end of the Kobuk Fault southwest to the Kaltag Fault (fig. 1; plates 1,2), there is a strong correlation between high-prospectivity HUCs and ARDF localities, and additional high-prospectivity HUCs suggest expansion of prospectivity beyond known occurrences (plate 2). The deposits in this area are associated with middle to upper levels of Cretaceous intrusions emplaced into high-grade metamorphosed Paleozoic continental margin rocks (Roeske and others, 1995) that are similar in composition and tectonic setting to rocks in the southern Brooks Range.

\section{East-Central Alaska}

In the Yukon-Tanana uplands (fig. 1), there is a strong correlation between high-prospectivity HUCs and known lode and placer occurrences (plate 2). Additional high- and medium-prospectivity HUCs expand the area of known occurrences, especially in the areas near Livengood, north of Fort Knox, Pogo, and near Tetlin (plates 1,2). This area is part of the Tintina gold belt, an area best known for intrusionrelated gold deposits that also has many geological and geochemical characteristics common to orogenic deposits (Hart and others, 2004a; Hart, 2007).

\section{Southwestern Alaska}

In the Kuskokwim Mountains of southwestern Alaska (fig. 1), high-prospectivity HUCs in our analysis correspond closely to one of the major gold placer districts in the State and are colocated with a densely populated belt of lode occurrences (plate 2) that include the Donlin Creek deposit and the Golden Horn, Chicken Mountain, and Saddle Mountain prospects. These deposits and prospects are associated with latest Cretaceous intrusive rocks emplaced in Upper Cretaceous flysch that overlies continental margin metasedimentary rocks. The type of gold system that yielded many of these deposits is debated; the prevalence of mercury in this part of Alaska indicates epithermal deposits may be present in addition to scheelite-, arsenopyrite-, and chalcopyrite-bearing deposits variably classified as epizonal orogenic, reduced-intrusion, and porphyry systems (Graham and others, 2013).

The Kuskokwim Mountains belt is intersected by a correlative latest Cretaceous belt of reduced, $\mathrm{Au}$-bearing, low- $\mathrm{Cu}$ sheeted vein and porphyry-related deposits, prospects and occurrences that crosses the western Alaska Range and includes Shotgun, Estelle, and Golden Horn (plate 1), as well as $\mathrm{Cu}-\mathrm{Pb}-$ $\mathrm{Sb}-\mathrm{Ag}$-Au-sulfosalt-bearing orogenic or epithermal(?) veins at Terra (Graham and others, 2013). This belt is underlain by a broad zone of medium- to high-prospectivity HUCs that expands the belt of known lode occurrences (plate 2).

On the Alaska Peninsula and extending down into the Aleutian Islands (fig. 1), sparse medium- and high-prospectivity HUCs correspond to lode and placer deposits associated with young volcanic rocks and hypabyssal intrusions, such as those that host the Apollo Mine, an epithermal gold deposit (Singer, 1999). The underlying rocks are Jurassic-Cretaceous shallow marine forearc deposits. The high-prospectivity HUCs in this area may include signals from orogenic and epithermal deposits.

\section{South-Central and Southeastern Alaska}

In south-central Alaska, a continuous belt of High-potential HUCs (plate 1) corresponds to a well-defined, densely populated belt of lode and placer occurrences in the Talkeetna Mountains (fig. 1; plates 1,2). These occurrences are hosted mainly by quartz veins in metamorphic rocks, which can be classified as orogenic systems; however, in some cases, such as at the Lucky Shot and Independence Mines in the Willow Creek District, the quartz veins are hosted by contemporary intrusive rocks.

Extending from the Kenai Peninsula to southeastern Alaska (fig. 1), Medium- to High-potential HUCs correspond closely to a densely populated belt of lode gold occurrences, prospects, and mines, including Crow Creek, Cliff, and HirstChichagof (plates 1,2). Small clusters of Medium-potential HUCs on the Kenai Peninsula indicate the possibility for additional occurrences. These deposits are found in quartz veins in sedimentary accretionary trench deposits proximal to near-trench anatectic plutons that are only slightly younger than their host rocks in the Chugach accretionary complex and are classified as orogenic gold deposits (Haeussler and others, 1995; Goldfarb and others, 2005).

In southeastern Alaska, three additional belts of Highpotential HUCs (plate 1) correspond to gold-bearing quartz veins in metasedimentary rocks in Devonian (for example, Puyallup-Dawson, Dolomi, southern Prince of Wales Island), Middle Cretaceous (for example, Maid of Mexico), and Eocene (for example, Kensington, Alaska-Juneau) belts of lode gold occurrences (plate 1). These belts are classified as orogenic gold systems (Maas and others, 1995; Goldfarb and others, 2005); however, their host rocks are locally interpreted to contain older gold deposits that formed in different oreforming systems, including intrusion-related gold in monzodioritic rocks at Kensington-Jualin and Treadwell (Newberry and others, 1995), and epithermal gold in metamorphosed felsic volcaniclastic rocks at Dolomi (Hedderly-Smith, 1993; Maas and others, 1995, and references therein). The middle Cretaceous orogenic belt on Admiralty Island appears to be the only under-prospected belt of High-potential HUCs in southeastern Alaska, but its location in a wilderness area in the Tongass National Forest prevents mineral entry. 


\section{Conclusions}

In conclusion, areas known to contain lode gold deposits and areas shown to have high prospectivity for gold in this GIS analysis for undivided lode gold deposits are strongly correlated, and our analysis expands prospectivity around areas of known gold occurrences. Land-use management decisions should account for the potential for future discoveries in these newly delineated areas. This analysis also provides a general framework for more focused and detailed district- and localscale analyses that emphasize local geologic characteristics and refine generalized State-scale scoring parameters.

\section{Chapter 2. Orogenic Gold Deposits}

Orogenic gold systems typically form in metamorphic rocks during the late stages of orogenic collisional events between geologic terranes. Orogenic belts form within and between terranes and are a common setting for orogenic gold deposits. Alaska is predominantly composed of displaced terranes that were accreted to North America, and orogenic belts, a fundamental result of accretionary processes, are a prevalent tectonic setting.

\section{Deposit Group Characteristics}

Orogenic lode gold deposits are most commonly found in rocks metamorphosed during regional orogenic events (Goldfarb and others, 2001). The most likely geologic settings to host orogenic gold deposits in Alaska are (1) greenschist facies metamorphic belts associated with Phanerozoic suture zones that involve crustal thickening and exhumation to shallower structural levels during progression of an orogenic episode, and (2) accretionary complexes overprinted by thermal anomalies associated with subduction of oceanic spreading centers or other sources of high heat flow as well as the generation of hydrothermal fluids and melts. Mineralized systems are hosted in deformed and variably metamorphosed rock units, typically greenschist facies rocks; however, orebodies of economic size may be present in both higher and lower grade metamorphic host rocks. Regional metamorphic belts that host orogenic gold deposits in Alaska include areas underlain by metasedimentary rocks - such as those on the Seward Peninsula, the southeastern Brooks Range, and east-central Alaska - and mixed metaplutonic, metavolcanic, and metasedimentary rocks - such as those in the Yukon-Tanana uplands, the Juneau gold belt, and southern Prince of Wales Island in southeastern Alaska. Accretionary complexes that host orogenic gold deposits associated with anatectic plutons underlie the Kenai Peninsula and Prince William Sound in south-central Alaska and Chichagof and Baranof Islands in southeastern Alaska (fig. 1). In some cases, devolatilized carbonaceous metasedimentary and metavolcanic rocks in host belts are a possible gold source for many orogenic deposits (Pitcairn and others,
2006; Tomkins, 2013; Goldfarb and Groves, 2015). Debate remains about possible sources of the gold in many deposits and occurrences in Alaskan orogenic belts. Orogenic gold deposits may also be associated with contemporaneous magmatism, such as at Lucky Shot in the Willow District in the Talkeetna Mountains. Most orogenic deposits do not appear to have a strong spatial or temporal association with intrusions, and thus a direct link to magmatism has not been satisfactorily established (Groves and others, 2016).

Orogenic gold deposits exhibit strong structural controls and typically form in dilatant zones such as fault jogs or fold hinges and in small-scale structures associated with regionalscale structures. Orebodies are commonly $2-10 \mathrm{~km}$ in length and $1 \mathrm{~km}$ in width and may be mined downdip for several kilometers (Goldfarb and others, 2005). Mineralization in orogenic belts is associated with low-sulfide quartz-carbonate veins that contain pyrite, arsenopyrite, and $\mathrm{W}-$, Bi-, and Te-bearing minerals. Alteration is typically cryptic, extending laterally outward from the veins and often characterized by carbonate phases, alkali metasomatism (chlorite, albite, sericite), and low-sulfidation state sulfide minerals such as pyrite, arsenopyrite, and pyrrhotite (Goldfarb and others, 2005). Gold to silver ratios are high in orogenic deposits, and base metals are generally absent to weakly anomalous (Goldfarb and others, 2005). Pathfinder geochemical suites are characterized by anomalous $\mathrm{As}, \mathrm{Bi}, \mathrm{Sb}$, Te, W, B, and sometimes Hg (Goldfarb and others, 2005).

Deposits of this class may form over a broad range of temperatures and pressures, and they may be further subdivided into epizonal, mesozonal, or hypozonal systems (Goldfarb and others, 2005). Gold-bearing orebodies hosted in metamorphic rocks are presumed to have formed millions of years after deposition of the host rocks, and late in the deformational history of the orogenic belt (Goldfarb and others, 2005). Low-salinity, $\mathrm{CO}_{2}$-rich fluids formed during metamorphic devolatilization transport gold to shallower crustal levels. Deposits are principally hosted in low-grade metamorphic rocks on a retrograde metamorphic path (Goldfarb and others, 2005, 2016; Goldfarb and Groves, 2015).

Host rocks to orogenic deposits have variable magnetic characteristics. Magnetic characteristics may be derived from primary or metamorphic minerals, independent of oreforming systems. Some orogenic belts in Alaska are hosted by mafic metavolcanic rocks, and these rocks tend to have a higher magnetic potential signature than nonvolcanic rocks. At medium and higher grades of metamorphism, iron-bearing minerals can be oxidized to yield magnetite (Winkler, 1976) and mafic volcanic rocks that are metamorphosed to greenschist facies or higher may have a higher magnetic signature in aerial magnetic surveys than adjacent rocks that are less mafic (Saltus and others, 2007). In contrast, metasedimentary rocks such as carbonaceous rocks, carbonate rocks, and siliciclastic flysch that might host orogenic deposits are not likely to contain magnetic minerals at any metamorphic grade. Orogenic gold belts in accretionary deposits in south central and southeastern Alaska have a spotty magnetic signature that corresponds to near-trench plutons, which have small discrete 
magnetic highs, hosted in trench sediments that have no magnetic signature. Gold mineralization tends to be associated with these near-trench plutons (Haeussler and others, 1995), so their magnetic signature is relevant, but many plutons in Alaska have magnetic signatures and are not associated with gold mineralization. Thus, magnetic character is not a consistent predictor of gold deposits in orogenic settings.

\section{Mineral Resource Potential Estimation Method}

The scoring strategy for estimating the potential for orogenic gold deposits in Alaska involves evaluating datasets with respect to parameters typically associated with orogenic gold systems. The most distinctive parameters discussed above for identifying areas prospective for hosting these deposits in our datasets are the presence of (1) As, Bi, Te, and W pathfinder elements and minerals in rock and sediment chemistry; (2) gold in HMC, rocks, and sediments; (3) metavolcanic or carbonaceous metasedimentary host rocks; (4) mineralized, typically banded quartz veins; and (5) a known orogenic deposit nearby (table 4). These parameters are weighted according to importance for defining this deposit type and contribute to a total score for each HUC. The spatially comprehensive rock and sediment geochemical datasets carried the dominant weighting in our scoring process. The lithologic dataset from the digital geologic map of Alaska (Wilson and others, 2015) helps to identify favorable metamorphic belts, but cannot pinpoint mineral concentrations in HUCs, so it was assigned limited weight in scoring. We limited the possible maximum point scores from the ARDF database to avoid biasing results toward known districts and to test potential for undiscovered orogenic deposits. A combination of the ARDF placer gold and HMC datasets is important in locating gold occurrences but owing to uneven coverage was assigned less weight than rock and sediment geochemistry. Aeromagnetic survey data do not have a consistent correlation between the magnetic character of host rocks and orogenic gold occurrences, and we did not apply the aeromagnetic dataset for this deposit type at the State scale. However, the aeromagnetic dataset might be effectively applied at a district scale where it can be correlated in detail with a specific rock type known to host orogenic deposits in a particular area.

The total possible score for potential for an orogenic gold deposit in our analysis is 99 points (table 4). If all datasets contribute to the total score, rock and sediment chemistry can compose as much as 67 percent of that score, HMC data as much as 18 percent, lithologic data a maximum of 10 percent, ARDF records as much as 5 percent, and magnetic data were not scored. Only the total score, statistically binned by the Jenks (1967) method, was used to determine High, Medium, or Low potential. The points and percentages that each dataset contributed to the total score for each HUC can be queried in ArcGIS and are tabulated in Karl and others (2021). Total scores are statistically analyzed and grouped by natural breaks (Jenks, 1967) to assign High, Medium, and Low classifications for potential to contain a gold resource.

\section{Lithology}

Common host rocks of orogenic gold deposits such as greenschist grade metasedimentary and metavolcanic rocks, mainly mica schist and quartz-feldspar schist (for the former), and metabasalt and amphibole schist (for the latter), were extracted from the nsalith table of the digital geologic map of Alaska (Wilson and others, 2015). These rock types were assigned three points for their general association with the orogenic deposit type. Carbonaceous metasedimentary rocks were also extracted from the dataset and assigned four points for their potential as a source and host for gold. Points for these lithologies are additive, yielding a possible maximum score of 10 (table 4). Application of this dataset contributed one point to the certainty score for a HUC (table 5).

\section{Alaska Resource Data File}

The ARDF contains information useful for discriminating orogenic gold deposits. To focus on identification of lode deposits, placer deposits were removed from the dataset prior to applying a keyword search. Instead, ARDF placer deposit records were combined with the HMC dataset and scored as part of the heavy mineral dataset. Points awarded for keywords in multiple fields in the ARDF that contain terms associated with orogenic gold systems can be found in appendix 2. Keywords referring to orogenic deposits in the deposit model field, such as orogenic, synorogenic, and Chugach-type, were given a high score (4 or 5 points). High scores were also assigned to key minerals and associations, including gold, bismuth, stibnite, and scheelite (and word strings like goldstibnite-quartz), and their respective constituent cations or elemental symbols ( $\mathrm{Au}, \mathrm{Bi}, \mathrm{Sb}$, and $\mathrm{W})$. Other common but nonunique minerals associated with orogenic deposits, such as quartz, ankerite, arsenopyrite, and sericite, were given lower scores (1-3 points), except where they occurred together in associations. For example, quartz alone received two points, but a string such as quartz-arsenopyrite received four points. Keywords describing alteration, structural, or lithological characteristics related to orogenic gold deposits, such as pyritic, fracture-controlled, and metabasalt, respectively, were given low to high scores based on their distinctiveness relative to this deposit type. Some of the most distinguishing keywords are summarized in table 14 .

Keyword totals were binned into representative ARDF scores of one point for totals of 17-34, three points for totals of 35-55, and five points for totals $>55$ (table 4 ). The application of ARDF keyword data contributed one point toward the certainty score for a HUC (table 5).

\section{Rock and Sediment Geochemical Data}

Elemental enrichments of $\mathrm{Au}, \mathrm{As}$, and Bi with associated pathfinders such as $\mathrm{W}$ and Te are common in areas containing or known to be prospective for orogenic gold systems. Arsenic 
and bismuth have the strongest association with orogenic systems, whereas tungsten may occur in the less reduced variants (Goldfarb and others, 2005). Such HUCs were scored utilizing a weighting based on the degree of anomalism of the specific element or element associations relative to background values (appendix 1). These HUCs received scores for rock and sediment geochemical values of pathfinder elements at statistically defined levels above background (appendix 1, table 4). The use of pathfinder elements such as As, Bi, W, and Te combined with an association of base metal minerals was chosen to distinguish the geochemical signature of orogenic from other gold systems (for example, Goldfarb and others, 2005; table 14).

The scoring rubric is outlined in table 4 and an example follows. For HUCs that have rock samples that contain arsenic or bismuth scoring $>7.5$ times background accompanied by elevated base metals copper, lead, and (or) zinc were scored in the following way. For base metal values of $>1.5$ times background and $<3.5$ times background, HUCs were assigned one point; for base metal values $>3.5$ times background and $<7.5$ times background, they were assigned two points; for base metal values $>7.5$ times background and $<15.5$ times background, they were assigned three points; and for base metal values $>15.5$ times background, they were assigned four points. Sediment samples containing arsenic and bismuth $>7.5$ times background and base metals accompanied by the above stated ranges were double weighted, and assigned 2, 4, 6, or 8 points, depending on the degree of anomalism. The maximum possible rock geochemistry score for the orogenic model is 33 points; the maximum possible sediment geochemistry score is 33 points. HUCs for which rock or sediment data are available received one point for each dataset toward the HUC total certainty score (table 5).

\section{Heavy Mineral Concentrate Data}

Records for placer gold in the ARDF were combined with the heavy minerals dataset from the AGDB3. Mineralogy for samples in the HMC dataset indicates the presence or absence of gold in a HUC. HUCs that contain a placer occurrence in the ARDF were assigned four points, HUCs containing native gold or gold-bearing mineral phases in the HMC component of the AGDB3 were assigned three points, and HUCs containing gold indicator minerals such as arsenopyrite or enargite for orogenic systems were assigned two points. Other minerals commonly associated with orogenic gold systems, such as stibnite or chalcopyrite were given a score of one point. The scoring is additive, yielding a maximum score possible for the ARDF placer-HMC mineralogy of 10 points (table 4).

HMC geochemistry was also used in the scoring process. HUCs were scored based on measured gold (four points), silver (two points), and arsenic or bismuth combined with base metals (one point), or $\mathrm{As}, \mathrm{Bi}, \mathrm{Te}$, or $\mathrm{W}$ at values $>1.5 \mathrm{x}$ background (one point), using background levels determined by Lee and others (2016) and Shacklette and Boerngan (1984) that are appropriate for our dataset (appendix 1). The maximum score for HMC geochemistry is eight points (table 4). Availability of ARDF placer-HMC data, regardless of whether the score was zero (that is, no minerals of interest present) or more (that is, minerals of interest identified), contributed one point to HUC certainty scores (table 5); a lack of ARDF placer and (or) HMC data for a HUC - a null value - contributed no points to the certainty score for a HUC.

\section{Results and Discussion}

Our analysis shows that HUCs that have high scores for potential correspond well with areas in Alaska known to contain orogenic gold deposits (Goldfarb and others, 2005; U.S. Geological Survey, undated). The distribution of HUCs that show Medium and High potential near known deposits (plates 2, 3) indicates that locally these belts can be expanded. High-potential HUCs that are in areas previously unrecognized to contain this deposit type are indicated by individual HUCs or small clusters of HUCs, commonly a result of sediment and rock geochemistry that contain anomalous gold and pathfinder element values (Karl and others, 2021) and should be verified on the ground.

\section{Areas that have Known and Newly Recognized Prospectivity for Orogenic Gold Deposits}

Some of the main known orogenic gold deposits in Alaska are shown on plate 3. To the first order, the GIS analysis highlights these deposits, including Rock Creek in the Nome District on the Seward Peninsula; Mikado in the eastern Brooks Range; Lucky Shot/Independence, Crow Creek, and Cliff in south central Alaska; and Kensington, Alaska-Juneau, and Treadwell in the Juneau gold belt in southeastern Alaska. Our prospectivity analysis indicates expansions of these areas and several areas that lack known gold deposits (plates 2,3).

\section{Northern Alaska}

Gold deposits in the Chandalar District in the eastern Brooks Range (fig. 1) are hosted in upper-greenschist-facies metasedimentary units, including carbonaceous and graphitic schists, that are intruded by intermediate to mafic dikes. The best-known deposit is the Mikado mine, which produced 7,700 ounces (oz) of gold (Barker and others, 2009). Occurrences in the district consists of low-sulfide, quartz-dominated zones as much as $2 \mathrm{~m}$ in width that contain sheeted veinlets, lenses, disseminations, and ribbon quartz. Mineralized quartz veins occur in regional shear zones and contain gold flakes and wires, and include associated arsenopyrite, scorodite, and minor stibnite, sphalerite, galena, and pyrite (Bundtzen and Laird, 2007; Barker and others, 2009). Alteration associated with the mineralized zones includes assemblages containing kaolinite, chlorite, quartz, albite, limonite, scorodite, siderite, and (or) ferroan dolomite.

Our analysis confirms High potential for HUCs that contain ARDF records for lode deposits in the Chandalar District (plate 2) and indicates additional HUCs that have High potential in the district. Our analysis also shows clusters of HUCs in the same belt of metamorphic rocks to the west in the Wiseman 
District in the southern Brooks Range where ARDF lode localities (for example, Wild Lake, Smith Creek; Chipp, 1972) are far less abundant than placer localities (plate 2), suggesting further exploration potential. Within the main Chandalar District, a core area of high prospectivity is flanked by medium-prospectivity HUCs (plate 3), which may represent potential targets under cover. The high-prospectivity HUCs around Mikado appear to represent the eastern terminus of a broadly east-west oriented belt of medium prospectivity in the southern Brooks Range.

\section{Seward Peninsula and North-Central Alaska}

The principal gold production on the Seward Peninsula (fig. 1) has been from the Nome District, which has seen production since the early 1900s derived mainly from terrestrial and beach placers (Collier and others, 1908) that have enigmatic lode sources. Placer deposits in the Nome District produced 5 million troy ounces (Moz) of gold and in the Council District produced 1 Moz of gold (Szumigala and others, 2011). Mining and exploration on the Seward Peninsula have not delineated lode resources or occurrences that can balance the substantial placer occurrences in the Nome and Council Districts (U.S. Geological Survey, undated; Nokleberg and others, 1987; Jones and others, 2016). Lode sources may have been removed by erosion and (or) unidentified lode sources may remain in the district, concealed beneath sediment or vegetative cover. Inferred lode sources include deposits and occurrences such as Rock Creek, Big Hurrah, and Bluff, which have long been considered orogenic in origin (Goldfarb and others, 1997). Parameters ranked in our GIS prospectivity model for orogenic gold systems highlight areas that contain these deposits in the Nome District (plates 2,3).

The host rocks in the Nome District consist dominantly of greenschist and blueschist grade metasedimentary rocks (Till and others, 2011) that include abundant carbonaceous schist and phyllite cut by multiple generations of sheeted lowsulfide quartz and quartz-carbonate veins (Otto and others, 2009; Pink, 2010). Alteration in the district includes silicification, albitization, and sulfidation (for example, pyrite and arsenopyrite). Rock Creek is the most extensively explored lode deposit in the Nome District and is characterized by sheeted quartz-calcite and quartz-feldspar veins that contain scheelite, arsenopyrite, galena, and pyrite, accompanied by abundant arsenopyrite disseminated in the wall rocks (Cathcart, 1922). The Rock Creek deposit has a reported $\sim 886,000$ oz of gold resource at a grade of 0.066 ounces per ton gold (oz/t Au; Szumigala and others, 2011).

Our analysis shows that HUCs that have High potential for orogenic gold deposits correspond well with the distribution of known occurrences in ARDF. Additionally, our model highlights HUCs that have no known lode mineral occurrences within the Nome and Council Districts (plate 2), suggesting expansion of the known areas of prospectivity in the district (plate 3).

On the eastern Seward Peninsula, a broadly north-south oriented zone of medium to high potential is identified in the orogenic model (plate 3 ). This correlates roughly to the location of the Kugruk Fault zone (fig. 1), which represents an amalgamation of kinematic events within a north-trending zone roughly 40 kilometers wide that defines the east margin of the Seward Peninsula. Orogenic-style gold occurrences are known in the northern part of the Kugruk Fault zone (Miller and others, 2015), where goldbearing quartz veins are associated with arsenopyrite and pyrite and have quartz-carbonate alteration extending into carbonaceous, carbonate, and siliciclastic metasedimentary wall rocks. HUCs showing medium to high prospectivity on the eastern Seward Peninsula suggest an underexplored area of interest for gold.

Other HUCs that show High potential for orogenic gold in our analysis are peripheral to middle Cretaceous alkaline plutons in a belt that extends from the Darby Mountains on the Seward Peninsula eastward to the Zane Hills (fig. 1). These plutons are known mainly for uranium and rare earth element occurrences (Miller, 1989), but locally they have associated gold-quartz and gold-base metal-quartz veins. Also, gold placer deposits in this belt (plate 2) lack known lode sources. The intrusive rocks are located within a regional orogenic belt that involved a Late Jurassic to middle Cretaceous collision of an oceanic arc with a passive continental margin that underlies the Seward Peninsula and southern Brooks Range (Miller 1989; Patton and Box, 1989; Dumoulin and others, 2014). The light red color of most of the HUCs in this belt indicates high scores for potential that are based on limited data, a consequence of poor exposure and reconnaissance investigations.

Pericontinental Precambrian and Paleozoic metasedimentary and metavolcanic rocks that host the Ruby batholith between the southern Brooks Range and the Kaltag Fault in north-central Alaska (fig. 1) were involved in Jurassic to middle Cretaceous orogenic events similar to those of the Seward Peninsula and southern Brooks Range. Sparse ARDF records indicate gold-bearing quartz veins occur in greenschist- and blueschistgrade metamorphic rocks that were emplaced beneath a Jurassic arc complex in an orogenic setting that persisted through emplacement of middle Cretaceous plutons (Roeske and others, 1995). Prospects such as Maggie Creek and Morelock Creek contain anomalous levels of gold, arsenic, and antimony in soil samples and in sulfide-bearing, quartz-calcite veins associated with an inferred stockwork in brecciated rocks at a fault intersection. These mineral occurrences are located upstream from known placer deposits and represent the only known major lode occurrences in the area. These ARDF records are located in HUCs for which scores indicate High potential but Medium to Low certainty and are located near a cluster of HUCs that have High potential and Medium to High certainty but lack ARDF localities (plate 2). Our analysis thus indicates expanded potential for lode gold deposits in this area of poor exposure and limited data.

\section{East-Central Alaska}

Precambrian and Paleozoic metamorphic rocks near and northeast of Livengood (fig. 1; plate 3) underlie a region referred to as the Yukon-Tanana uplands (fig. 1). In this area, HUCs that have high prospectivity for orogenic gold are coincident with, and peripheral to, known lode gold deposits, suggesting additional prospectivity in areas of poor exposure and limited data. 
The Yukon-Tanana uplands in east-central Alaska are included within the broadly classified Tintina gold belt and include two of the major placer districts in Alaska, the Fortymile and Sixtymile Districts. These districts have each produced approximately $500,000 \mathrm{oz}$ of gold since the late 1800s (Yeend, 1996; LeBarge and Coates, 2007), yet the production and estimation of lode gold resources only accounts for $\sim 1,000 \mathrm{oz}$ in that area (Allan and others, 2013). Major lode gold deposits in the uplands include the Pogo mine, which produced 3.638 Moz of gold and has an estimated remaining resource of 3.34 Moz of gold as of year-end 2017 (Athey and Werdon, 2018). The deposit at Pogo (plate 3) is located within the Liese zone, characterized by several stacked, moderate to shallow northwest- to north-dipping quartz veins. The veins were emplaced into biotite-quartz-feldspar orthogneiss, approximately $2 \mathrm{~km}$ southwest of the Goodpaster batholith (Rhys and others, 2003). The veins postdate the metamorphic deformation and postmetamorphic intrusions (Smith and others, 2000; Selby and others, 2002), including sulfide-bearing pegmatites associated with the Goodpaster batholith (Rhys and others, 2003). The main mineralized vein assemblage consists of quartz-pyrite-arsenopyrite \pm pyrrhotite \pm chalcopyrite $\pm \mathrm{Mg}-\mathrm{Fe}$ carbonates accompanied by accessory fine-grained bismuthinite, native bismuth, native gold, galena, sphalerite, and molybdenite. Traces of these phases occur within or near sulfide-bearing bands or are encapsulated within pyrite or arsenopyrite veinlets (Rhys and others, 2003). Alteration extending laterally outward from the veins consists of green to beige sericite-muscovite, $\mathrm{Mg}-\mathrm{Fe} \pm \mathrm{Ca}$ carbonate and lesser dolomite. Alteration is manifested as envelopes overprinting peak metamorphic mineral assemblages and may extend as much as $10 \mathrm{~m}$ away from the veins (Rhys and others, 2003). The origin of Pogo is classified by some workers as orogenic (Goldfarb and others, 1997), by others as intrusion-related (Rhys and others, 2003), and may represent a continuum or an overlap of orogenic and intrusion-related gold deposit types (Selby and others, 2002).

The upland region has many characteristics of orogenic systems, including scattered small occurrences that are characterized by quartz-dominant, low sulfide, gold-bearing veins associated with carbonate- and epidote-rich styles of alteration. These veins have abundant stibnite and arsenopyrite along with low base metal associations. The host rocks in the region include a variety of mica- and chlorite-rich schists correlative with the Klondike and Fortymile assemblages; the Klondike schist is the principal host in the Klondike and White Gold Districts in the Yukon (Allan and others, 2013) where recent and active lode gold discoveries are numerous (for example, White Gold and Coffee).

Lode sources for the placer gold in east-central Alaska remain enigmatic regarding deposit type. Our model mainly highlights isolated, high-prospectivity HUCs localized around the major known gold occurrences such as Fort Knox and Livengood, which are not orogenic in character but show high prospectivity in our orogenic gold analysis (plate 3 ). This likely reflects an overlap of the key geochemical and geologic features of orogenic and intrusion-related gold mineralization used in this analysis but does not preclude the possibility of the presence of both deposit types. For example, a zone of high prospectivity between Fort Knox and Pogo has many placer occurrences but few orogenic-style ARDF occurrences (plate 2). Also, a continuous zone of high prospectivity and Medium to High certainty for HUCs north of Fort Knox and Pogo in the Circle District parallels the Tintina Fault. Lastly, a zone of high prospectivity in the Fortymile District in easternmost Alaska is associated with amphibolite facies metamorphic rocks. This is an area of continued high interest, particularly with recent discoveries just across the Yukon border in the same host rocks. Furthermore, a protracted and complicated tectonic history that can be documented throughout the upland involved numerous pulses of mineralization from the Permian through the Eocene (Kreiner and others, 2019). Thus, superposition of deposit types should be expected when exploring in the region, and detailed observations should be used to understand the time-space evolution of systems in the region. Compounding the difficulty of recognizing these enigmatic systems in the field, the region is characterized by extensive vegetative and young colluvial and loess cover. Recognizing these challenges, GIS analysis offers useful insights for identifying areas that may contain gold occurrences, information that may help focus future work.

\section{Southwestern Alaska}

In southwestern Alaska, an elongate northeast-oriented belt of high-prospectivity HUCs is highlighted by our orogenic model in a zone broadly coincident with the Kuskokwim Mountains (fig. 1; plate 3), which extends for more than 350 $\mathrm{km}$ north-northeast-south-southwest and is approximately 100 $\mathrm{km}$ in width. Many of the ARDF occurrences in this belt score for the orogenic model, and the high-prospectivity HUCs in many cases directly correspond to known occurrences of gold-bearing quartz veins. This belt also includes known gold occurrences and prospects such as Golden Horn, Chicken Mountain, Saddle Mountain, and Donlin Creek that contain strong ties to broadly coeval igneous activity, including a strong association with mercury enrichments and much higher base metal (copper-lead-zinc) signatures than many of the classic orogenic gold systems. In the Kuskokwim region, latest Cretaceous dikes and stocks were emplaced into the Upper Cretaceous Kuskokwim flysch behind an active arc built on multiple newly accreted terranes along the paleo-North American margin (Bundtzen and Laird, 1983; Goldfarb and others, 2004 ), and orogenic activity may have extended over a broad zone associated with terrane accretion in this area.

The Kuskokwim belt contains a variety of deposit types. Previous workers have classified the Golden Horn and Chicken Mountain prospects as porphyry systems (Bull, 1988; Bundtzen and others, 1992). These systems have strong associations with porphyritic igneous rocks, hydrothermal biotite alteration, and abundant copper-lead-zinc signatures. The Saddle Mountain prospect and the Bonanza pluton, associated with the Nyac batholith, saw high-temperature mineralization, indicated by quartz veins containing native 
gold-pyrite-chalcopyrite-magnetite-bismuthinite-molybdenite that are correlative in age with the Bonanza pluton and considered to be intrusion related (Wenz, 2004). Younger lowtemperature styles of alteration are characterized by mercury-rich chalcedonic and vuggy quartz textures associated with sericitealtered granodiorite porphyry dikes (Wenz, 2004). Donlin Creek continues to be an enigmatic deposit to classify. Currently, two distinct styles of mineralization are recognized at Donlin Creek and include an early, higher-temperature quartz-base metal-gold stockwork veining event overprinted by a younger gold-arsenopyrite-pyrite vein event where gold is refractory in the arsenopyrite (McCoy and others, 1997; Szumigala and others, 2000; Hanson and others, 2009). Like many deposits in the Kuskokwim region, Donlin Creek has a strong spatial and possible genetic relation to igneous dikes and stocks (Goldfarb and others, 2004) and is therefore not considered in this study to represent an endmember orogenic gold system.

The belt of high prospectivity in the Kuskokwim Mountains demonstrates the overlap in criteria for orogenic, intrusion-related, and possibly epithermal deposits. Although this region has been highlighted as being highly prospective in our orogenic model, its association with mercury and igneous dikes suggests an overlap of geochemical and geologic features from other system types. In the southern part of the belt, many of the high-prospectivity HUCs have few to no known occurrences (plate 2). Thus, although this region remains highly prospective for orogenic gold systems, other types of gold-bearing hydrothermal systems may likely be discovered.

The isolated High-potential HUCs to the west of the Kuskokwim belt and north of the Yukon River (plate 3) are in a gold placer district that does not contain ARDF localities for lode deposits (plate 2), and thus is an area recognized by this study inviting further investigation. The placer deposits locally contain hematite, magnetite, chalcopyrite, galena, scheelite, and cinnabar along with the gold. The nearest lode deposits in the district contain disseminated cinnabar and stibnite in brecciated and hydrothermally altered rhyolite; rock and soil samples contain $\mathrm{Au}, \mathrm{Ag}, \mathrm{As}, \mathrm{Sb}, \mathrm{Hg}, \mathrm{Cu}, \mathrm{Pb}$, and $\mathrm{Zn}$ (RM007 in https://ardf.wr.usgs.gov/; U.S. Geological Survey, undated). These characteristics are typical of epithermal deposits. Slightly farther away are occurrences of polymetallic $(\mathrm{Cu}$, $\mathrm{Pb}, \mathrm{Mo}, \mathrm{W}$ ) quartz veins in low-grade metasedimentary and metavolcanic rocks, characteristics that are more typical of orogenic deposits. It is possible that early orogenic deposits of Late Cretaceous age associated with 74-69 million years ago (Ma) intrusive rocks of the Kuskokwim Mountains (Graham and others, 2013) are overprinted by epithermal systems associated with the contemporaneous to slightly younger 72-60 Ma rhyolites (Moll-Stalcup, 1994).

\section{Western Alaska Range}

The western Alaska Range (fig. 1) is highlighted as highly prospective in the orogenic gold model (plate 3 ). Most of the HUCs in this area have high scores for potential but do not have High certainty. Known mineral occurrences are present throughout the prospective area; however, none are currently identified as orogenic in nature. The area is underlain by a middle Cretaceous collision zone between the WrangelliaPeninsular composite oceanic arc and the pericontinental Farewell terrane. The predominant deposit types in the region are magmatic-hydrothermal systems associated with spatially overlapping Jurassic through Eocene arcs that were active before, during, and after terrane collision (Plafker and Berg, 1994). Noteworthy occurrences include the Whistler (76 Ma) and Terra $(71 \mathrm{Ma})$ porphyry-related systems and the Estelle (70 Ma) intrusion-related gold systems (Graham and others, 2013; Taylor and others, 2014). The active arc in this area spatially coincides with the collision zone; however, the substantial presence of coeval plutonism and associated mineralization is uncharacteristic of geologic settings favorable for orogenic gold mineralizing systems. The high-prospectivity HUCs shown in the orogenic model (plate 3) likely reflect an overlap of similar geologic and geochemical characteristics from orogenic- and magmatic-hydrothermal systems.

\section{South-Central Alaska}

In south-central Alaska, the Talkeetna Mountains (fig. 1) include the Willow District, which has recorded production of $609,000 \mathrm{oz}$ of gold (Szumigala and others, 2011). In the Willow District, Lucky Shot, Independence, and Gold Bullion were the three largest producing mines; there is currently renewed activity at Lucky Shot (fig. 1; plate 3). Gold occurrences in the Willow District consist of granite-hosted, lowsulfide, banded quartz veins containing free gold, arsenopyrite, antimony-bismuth-tellurides, scheelite, and base-metal sulfides (Ray, 1954). The veins have associated alteration, which may extend as much as $30 \mathrm{~m}$ into the wall rock, characterized by sericite-carbonate \pm pyrite \pm chalcopyrite transitioning to chloritecalcite (Ray, 1954). The Willow Creek intrusive complex was emplaced in a zone of juxtaposed arc terranes (Ridgway and others, 2002; Rioux and others, 2007) and was cut by goldquartz veins that have white mica ${ }^{40} \mathrm{Ar} /{ }^{39} \mathrm{Ar}$ cooling ages of $70-66 \mathrm{Ma}$ (Harlan and others, 2003) which overlap zircon U-Pb ages of 76-67 Ma for the intrusive complex (Bleick and others, 2012). Stable isotope and fluid inclusion studies of the goldbearing quartz veins indicates their fluid sources were metamorphic (Burleigh, 1987; Goldfarb and others, 1997) but are also consistent with derivation from late phases of the host intrusive rocks (Burleigh, 1987). The association of the mineralized quartz veins with igneous host rocks of correlative age suggest the possibility of a magmatic-hydrothermal contribution.

The orogenic model used in our analysis highlights HUCs in the immediate vicinity of the Willow District as being highly prospective (plate 3 ). Discontinuously extending to the northeast are scattered HUCs of medium prospectivity, and farther to the northeast in the Talkeetna Mountains (fig. 1) is a band of HUCs that have high prospectivity, which coincide with the Valdez Creek District (plate 2). In this area are a few small prospects hosted by gold-quartz veins in the highly deformed McClaren schist, but these lodes account for 
only $1,581 \mathrm{oz}$ of gold compared to the $532,062 \mathrm{oz}$ of placer gold produced in the Valdez Creek District (Athey and others, 2013). The McClaren schist is part of the orogenic belt that formed along the inboard flank of the Wrangellia-Peninsular composite terrane during juxtaposition with the margin of North America in middle Cretaceous time (Plafker and Berg, 1994). Together, the geologic setting, the production records from the placer district, and our analysis (plate 3) suggest this area is highly prospective for orogenic gold systems.

A belt of orogenic gold deposits in an accretionary complex setting extends from the Kenai Peninsula into Prince William Sound and includes the Crow Creek and Cliff Mines (plate 3), which have seen minor past production. At Crow Creek, quartz veins as much as 30 centimeters in thickness contain free gold, arsenopyrite, pyrite chalcopyrite, pyrrhotite, molybdenite, and galena (Park, 1933). Sericite in gold quartz veins and white mica from the adjacent Crow Pass stock both yielded ${ }^{40} \mathrm{Ar} /{ }^{39} \mathrm{Ar}$ cooling ages of $\sim 54 \mathrm{Ma}$; the stock intrudes Upper Cretaceous flysch of the Chugach accretionary complex and is considered to be an anatectic pluton derived from heating of trench sediments above a subducting spreading center (Haeussler and others, 1995). Quartz veins at the Cliff Mine cut flysch of the accretionary complex are as much as $2 \mathrm{~m}$ in thickness, and contain gold, pyrite, arsenopyrite, galena, sphalerite, and stibnite (Hoekzema and others, 1986).

In this region, our analysis indicates high-prospectivity HUCs correspond directly with areas that contain known orogenic-style lode deposits, which supports the capability of our analysis to identify additional areas that have potential for orogenic gold mineralization. It follows that HUCs that show as highly prospective yet have sparse to no known orogenicstyle mineral occurrences, particularly in the southern Kenai Peninsula and northern Prince William Sound, are likely areas of interest. A swath of HUCs on the southern Kenai Peninsula that show high prospectivity but low certainty (plate 3 ) contain abundant dikes and small plugs inferred to be Tertiary neartrench intrusions in flysch of the Chugach accretionary complex (Bradley and others, 1999), similar to the rocks that host the Crow Creek and Cliff Mines. This region, despite having only minor historical production, remains prospective for orogenic gold systems and is perhaps underexplored in parts of the belt that show high prospectivity. Along strike in this belt, Kodiak Island contains similar near-trench intrusions in rocks of the Chugach accretionary complex and may be underexplored for orogenic deposits but is not highlighted in our analysis due to sparsity of data (gray color on all plates).

\section{Southeastern Alaska}

Highly prospective HUCs delineated by our analysis in southeastern Alaska correlate well with known orogenic systems in the Juneau, Chichagof Island, and Prince of Wales Island areas (fig. 1; plate 3). The Juneau gold belt extends for more than $300 \mathrm{~km}$ in strike length; produced more than 6.07 Moz of gold prior to 1945 (Goldfarb and others, 1991); and includes the active Kensington Mine, which produced 814,622 oz of gold and has a resource of $1.699 \mathrm{Moz}$ of gold as of yearend 2017 (Athey and Werdon, 2018), as well as the past-producing Alaska-Juneau and Treadwell Mines. Occurrences in the Juneau gold belt are hosted in quartz veins in greenschist facies carbonaceous metasedimentary and mafic metavolcanic rocks that structurally underlie the Coast Mountains Complex (Brew and Ford, 1985; Goldfarb and others, 1988; Miller and others, 1992). Ore zones consist of centimeter- to meter-wide, goldbearing quartz veins and vein networks hosted by ductile-brittle shear zones that extend for hundreds of meters along strike. The quartz veins contain ankerite, arsenopyrite, pyrrhotite, galena, sphalerite, calaverite $\left(\mathrm{AuTe}_{2}\right)$, petzite $\left(\mathrm{Ag}_{3} \mathrm{AuTe}_{2}\right)$, and minor pyrite; tellurium is the most reliable indicator of the presence of gold (Sack and others, 2016). Gold is found in quartz veins and adjacent fractures in the wall rock (Twenhofel, 1952).

Most of the lode gold deposits in the Juneau gold belt are hosted in calcareous carbonaceous rocks. Notably, the Treadwell and Kensington deposits are hosted in monzodioritic rocks that contain anomalous levels of gold and copper. This relation has led to some debate as to whether the orogenic vein deposits formed in shear zones cutting older intrusion-related gold systems (Newberry and Brew, 1987; Newberry and others, 1995; Miller and others, 2000; Karl and others, 2010b). Our analysis identified High-potential HUCs that correspond directly to known deposits in the Juneau gold belt, which has a dense population of ARDF records for lode gold (plate 2). Of interest are High-potential HUCs that lack ARDF localities in rocks along strike with the Juneau gold belt to the east of Zarembo Island (fig.1; plate 3), which have high certainty, suggesting a possible extension of the Juneau gold belt.

A belt of HUCs that indicate high prospectivity in our orogenic model on Admiralty Island (fig. 1, plate 3) are coincident with sparse gold-bearing ARDF localities that have orogenic gold affinities but have not been considered to be an orogenic gold belt. This metamorphic belt is west of the Juneau gold belt and has evidence for older orogenic events. Quartz veins in the Juneau gold belt are Eocene (Miller and others, 1994, 1995); dated quartz veins and metamorphic rocks on Admiralty Island indicate middle Cretaceous, Late Jurassic, and early Permian metamorphic-deformation events (Karl and others, 1998, 2010a; Haeussler and others, 1999). The middle to Late Cretaceous orogenic belt that extends for the full length of southeastern Alaska is attributed to the collision of the composite Alexander oceanic terrane with western North America. This orogenic belt contains gold-quartz veins, including one dated at $92 \mathrm{Ma}$ at the Maid of Mexico mine on Woewodski Island (fig. 1; Taylor, 2003; Karl and others, 2010b). The regional Cretaceous orogenic event may have provided a thermal and tectonic environment for remobilizing previous gold concentrations, including spatially coincident Triassic massive sulfide deposits such as Greens Creek on Admiralty Island that contain some gold (Athey and Werdon, 2018).

Lode gold deposits located on the west coast of Chichagof and Baranof Islands in southeastern Alaska consist of gold-bearing ribbon quartz veins cutting flysch of the ChichagofBaranof accretionary complex near anatectic near-trench plutons 
similar to those in south-central Alaska (Haeussler and others, 1995; Bittenbender and others, 1999; Karl and others, 2015b). These quartz veins contain free gold and sparse pyrite and arsenopyrite (Bittenbender and others, 1999). Our analysis shows a discontinuous belt of High-potential HUCs that include dated lode gold deposits located adjacent to contemporaneous Eocene plutons (plate 3; Haeussler and others, 1995; Karl and others, 2015b).

In southern southeastern Alaska, lode gold deposits are clustered on the southern half of Prince of Wales Island (plate 2). Numerous ARDF records there correspond to mines that had limited gold production between 1902 and 1946 (Maas and others, 1995); one, the Dawson, is a currently active small mine. Several deposits near the Puyallup and Dawson Mines are hosted by sheeted quartz veins in Ordovician volcaniclastic sandstone and carbonaceous argillite. None of these quartz veins have been dated, but a nearby pluton yielded an Early Devonian mica ${ }^{40} \mathrm{Ar} /{ }^{39} \mathrm{Ar}$ age which correlates with the age of a major orogenic event in southern southeastern Alaska (Zumsteg and others, 2004; Karl and others, 2005, 2015c) referred to as the Klakas orogeny (Gehrels and Saleeby, 1987).

The Dolomi area on southern Prince of Wales Island (plate 3) produced small amounts of gold between 1900 and 1933 (Maas and others, 1995). The host rocks consist of chlorite schists, carbonaceous schist, greenstone, and marble of the Neoproterozoic Wales Group, intruded by an undated metamorphosed alkalic intrusive complex. Occurrences consist of low-sulfide, gold-bearing quartz veins that are both conformable and unconformable with the metamorphic fabric, and conformable copper-gold-bearing, quartz-marble breccia zones that have gold-silver ratios averaging $2: 1$. These veins and breccias are associated with quartz-sericite schists that independently have high disseminated gold contents, as much as 2 parts per million (ppm) gold over $4.5 \mathrm{~m}$ and $1.8 \mathrm{ppm}$ gold over $6 \mathrm{~m}$, in mineralized horizons that lack veins or breccia and extend as much as a kilometer along strike, interpreted as possibly having exhalative protoliths (Maas and others, 1995, and references therein). The genesis of the mineralized quartz veins, many of which commonly occupy shear zones, is debated, and may involve remobilization of metals during amphibolite facies metamorphism of the Early Ordovician Wales orogeny or during greenschist facies metamorphism of the Early Devonian Klakas orogeny (Maas and others, 1995; Zumsteg and others, 2004).

\section{Conclusions}

The GIS analysis for orogenic gold applied scoring parameters that are based on global and Alaska-specific geochemical and geologic characteristics of orogenic gold systems. The map produced from this analysis (plate 3 ) shows strong correlations between areas of high prospectivity and areas of known orogenic gold style mineralization, particularly in the Juneau gold belt, the southeastern Brooks Range, the Tintina gold belt, and the accretionary complexes in southern and southeastern Alaska, suggesting the model accurately predicts highly prospective areas for orogenic gold.

\section{Chapter 3. Reduced Intrusion-Related Gold Deposits}

Despite wide variations in the tectonic settings inferred for the emplacement of reduced intrusion-related gold (RIRG) systems, most, if not all, formed above, or within, old and tectonically thickened, typically continental, crust (Thompson and others, 1999) in a setting distal to active convergent margins at the time of emplacement (Lang and Baker, 2001). In Alaska, the Arctic, Ruby, Yukon-Tanana, and Farewell terranes are continental fragments accreted to the North American continental margin, inboard of accreted and active arcs, and are thus located in favorable settings for generation of potential gold-bearing ilmenite-series magmas in RIRG systems. Large regions in Alaska that have undergone crustal thickening following terrane collisions are known to contain or may contain reduced or ilmenite-series intrusive systems capable of hosting high tonnage gold deposits (Thompson and Newberry, 2000; Hart and others, 2004a; Hart, 2007). Although RIRG systems in Alaska and Yukon have been interpreted as having formed on the craton side of a continental margin arc (Hart and others, 2004a), significant variation in tectonic settings has been documented (Lang and Baker, 2001).

\section{Deposit Group Characteristics}

Reduced intrusion-related gold systems are generally associated with metaluminous to slightly peraluminous intermediate to felsic ilmenite-series granitoids (Ishihara, 1977, 1981). The ilmenite association indicates the RIRG systems are associated with dominantly reduced primary oxidation state intrusions (Hart and others, 2004b), and it is inferred that the lower oxygen fugacity and composition of magmatic fluids that fractionate from reduced systems foster transport and concentration of key elements including Au, Bi, As, and Te (Thompson and Newberry, 2000). Ilmenite reflects the dominance of $\mathrm{Fe}^{+2}$, indicating a lower oxidation state. These granites are also characterized by negative values for sulfur isotopes, attributed to the correlation of biogenic sulfur with organic carbon, which are invoked as a major factor in the evolution of reduced granitic rocks (Ishihara, 1981; Ishihara and Terashima, 1989). The sources of these reduced intrusions include crustal melts and melts contaminated by crustal assimilation, especially of reduced carbon- and sulfur-bearing sediments that lower the oxidation state of the magma (Ishihara, 1977, 1981, 1998). These intrusions are commonly multiphase complexes that can compose batholiths, large or small plutons, irregular domes, dome complexes, or dike swarms (Thompson and others, 1999; Lang and others, 2000; Thompson and Newberry, 2000). The gold deposits are typically found in late-stage dikes, veins, greisens, and disseminations in adjacent host rocks. Lamprophyres associated with some RIRG-mineralized granitoids in Alaska and Yukon may be linked to the precursor melts (Hart and others, 2002; Hart, 2007). RIRG intrusions may have 
metamorphic aureoles that extend as much as several kilometers outward and that may have disseminated gold derived from late fluids (Lang and Baker, 2001).

Mineralization associated with reduced systems is variable, but is typically low-total sulfide, low sulfidation state, and is associated with subtle, cryptic hydrothermal alteration. The sulfide content of RIRG systems is low, less than 5 percent; the predominant sulfide assemblage is pyrite-pyrrhotitearsenopyrite (Thompson and Newberry, 2000). Metal assemblages are characterized by anomalous $\mathrm{Bi}, \mathrm{W}, \mathrm{As}, \mathrm{Te}, \pm \mathrm{Sb}$; base metals are generally weakly anomalous to absent (Lang and Baker, 2001), possibly because they precipitate early as sulfides while incompatible metals like tungsten remain mobile (Hart, 2007). Tungsten is commonly cospatial and an integral pathfinder, but gold and tungsten do not correlate (Lang and Baker, 2001).

Mineralization is strongly zoned around causative plutons and often is quartz vein-dominated. Quartz veins have a variety of forms, including sheeted to stockwork veining. Gold is also commonly disseminated outside of vein zones in favorable host rocks (Lang and Baker, 2001). Hart (2007) detailed strong lateral zoning of differing styles of mineralization, including intrusion-hosted, proximal tungsten (skarn) deposits, and distal (primarily disseminated- and breccia-hosted) silver-lead-zinc deposits located outboard of the hornfels aureole. Alteration in or near plutons is commonly characterized by early, gold-poor feldspathic (sodium- or potassium-feldspar) assemblages and later, gold-rich sericitic (Maloof and others, 2001) or greisen (Yao and others, 1999) overprints.

Gold mineralization is associated with anomalous $\mathrm{Bi}, \mathrm{W}$, $\mathrm{As}, \mathrm{Te}, \pm \mathrm{Sb}$; bismuth is high proximal to plutons, and arsenic and antimony tend to be dominant in deposits more distal to plutons (Thompson and Newberry, 2000). Gold is strongly correlated with bismuth in or near plutons (Thompson and Newberry, 2000), to a lesser extent with tellurium, and has a variable correlation with $\mathrm{As}, \mathrm{Mo}, \mathrm{Ag}$, and $\mathrm{Pb}$ (Lang and Baker, 2001). Base metals are generally weakly anomalous to absent (Lang and Baker, 2001).

\section{Mineral Resource Potential Estimation Method}

All six datasets were applied to the prospectivity analysis for RIRG deposits. Scoring was weighted to emphasize parameters that discriminate this deposit type. The primary parameters, as discussed above, delineated in table 6 and summarized in table 14, include intrusive rock types, known deposits of this type in the area, the presence of gold and distinguishing pathfinder trace elements, the presence of distinguishing HMC assemblages, and aeromagnetic data filtered to recognize ilmenite-series intrusive rocks.

The total possible points for potential for an intrusionrelated gold deposit in our analysis is 89 points (table 6). If all datasets contribute to the total score, rock and sediment chemistry can carry as much as 56 percent of that score, HMC data as much as 21 percent, lithology as much as 13 percent, ARDF scores as much as 6 percent, and magnetic data a maximum of 3 percent of the total score for this deposit type. Only the total score, statistically binned by the Jenks (1967) method, was used to determine High, Medium, or Low potential. The points and percentages that each dataset contributed to the total score for each HUC can be queried in ArcGIS and are tabulated in Karl and others (2021).

\section{Lithology}

For this analysis, favorable rock types for intrusion-related systems, as discussed above, are mainly felsic to intermediate plutonic rocks and lamprophyre dikes. These rock types were extracted from the State geologic map dataset (Wilson and others, 2015) and scored if they were present, but were not required to be the dominant rock type in a HUC. Felsic plutonic rocks in the nsalith database (appendix 3) include granite and granodiorite, whereas intermediate plutonic rocks encompass a wide variety of types classed as diorite, along with monzonite and quartz monzonite. The intrusive rocks unit descriptions generally lack information to determine whether they can be classified with the ilmenite-series suite of granitoids. As a result, both oxidized and reduced igneous associations can receive a small score for this parameter and little weight was assigned. HUCs received four points each for the presence of appropriate intrusive rock types as designated in the nsalith database additively, allowing a maximum possible lithology score of 12 points (table 6). Application of this dataset contributed one point to the certainty score (table 7).

\section{Alaska Resource Data File}

The ARDF database provides strong indications of specific types of deposits. Recognizing that specific deposit types are often clustered in favorable settings, we limited the scoring of known deposits to avoid biasing results toward known districts and instead to address potential for undiscovered deposits. Records from the ARDF database were searched and scored for intrusion-related deposit group keywords (appendix 2); deposit model keywords such as intrusion-related, intrusion-hosted, Fort Knox-type, and variations thereof, were assigned high weight (four or five points). Main ore mineral keywords such as gold, stibnite, and scheelite were assigned three to five points. Appropriate host rock types such as felsic plutonic, and alteration descriptors such as potassic and sericitization, although important in RIRG systems, are common in other deposits, such as porphyry systems, and were given less weight (two to four points). Total ARDF keyword scores for intrusion-related deposits for each record were statistically grouped using natural breaks (Jenks, 1967). HUCs that had totals of 14-27 keyword points were assigned one point toward their score for potential, HUCs that had totals of 28-46 keyword points received three points, and HUCs that had keyword totals $>46$ received five points toward the HUC score (table 6). Application of this dataset contributed one point to the certainty score for a HUC (table 7). 


\section{Rock and Sediment Geochemical Data}

In our analysis for intrusive-related gold, the heaviest weight was placed on rock and sediment chemical data owing to good statewide coverage. Primary emphasis was placed on the presence of gold and pathfinder elements for RIRG, including $\mathrm{Au}$, $\mathrm{Ag}, \mathrm{Bi}$, and $\mathrm{Te}$ and associated $\mathrm{W}, \mathrm{Sb}, \mathrm{Cu}$, or $\mathrm{Mo}$, which contrasts with the emphasis on arsenic and associated base metals for the orogenic model above (table 14). For both the sediment and rock geochemistry databases, the enrichment of elements on a pseudologarithmic scale above background concentrations determined statistically for Alaskan sediment data (Lee and others, 2016) and by the median crustal abundances for rocks (Wedepohl, 1995) was used to determine the scoring (appendix 1).

The maximum possible score for rock geochemistry is 23 points (table 6). This includes six points from anomalous gold, five points from anomalous silver, and 12 points possible from pathfinder suites of minerals, such as bismuth in association with tungsten, molybdenum, or copper (maximum of six points), or $\mathrm{As}, \mathrm{Bi}, \mathrm{Sb}$, or Te at levels $>7.5$ times background, additively. HUCs for which rock data are available received a maximum of one point toward the certainty score for a HUC (table 7).

Sediment geochemistry can contribute a maximum score of 27 points in this analysis (table 6). Seventeen points are possible from the presence of gold and silver, based on the degree of enrichment above the median sediment value for Alaska (Lee and others, 2016). The remaining 10 points are from the combination of $\mathrm{Bi}$ and $\mathrm{W}, \mathrm{Mo}$, or $\mathrm{Cu}$, and the presence of $\mathrm{As}, \mathrm{Bi}, \mathrm{Sb}$, or Te. HUCs for which sediment data are available received a maximum of one point toward the certainty score for a HUC (table 7).

\section{Heavy Mineral Concentrate Data}

Placer gold occurrences were considered as heavy mineral localities and combined with the HMC dataset to test for the presence of gold in a HUC. HUCs containing a placer gold occurrence in the ARDF were assigned four points, HUCs containing native gold or gold-bearing mineral phases in HMC from stream sediments were assigned three points, and HUCs containing gold indicator minerals in panned sediment concentrates received two points. Associated minerals related to intrusion-related gold systems such as arsenopyrite, bismuth oxides, or stibnite were assigned a score of one point. Points for mineralogy are additive; the maximum score available for the HMC mineralogy is 10 points (table 6).

HUCs were also scored based on HMC geochemistry, for which analyzed gold was assigned four points; silver two points; a combination of Bi plus $\mathrm{W}, \mathrm{Cu}$, or Mo two points; and analyzed $\mathrm{As}, \mathrm{Bi}, \mathrm{Te}$, or $\mathrm{Sb}$ received one point. Points for HMC chemistry are additive; the maximum possible score is nine points (table 6). Availability of HMC data, regardless of whether the score was zero (that is, no minerals of interest present) or more (that is, minerals of interest identified), contributed one point to the certainty score for a HUC (table 7); a lack of HMC data for a HUC - a null value - contributed no points to the certainty score for a HUC.

\section{Aerial Magnetic Survey Data}

Granitic rocks can be classified into oxidized, magnetiteseries intrusive suites that are very magnetic and reduced ilmenite-series intrusive suites that are poorly magnetic to nonmagnetic (Ishihara, 1977, 1981). A complication is that areas of anomalously low magnetization around plutons can correspond to alteration of iron-bearing minerals and can be useful information about alteration and potential epithermal deposits.

In the analysis for RIRG, we filtered the aeromagnetic dataset as described in the Data Types and Analytical Process section and applied scores only to cells that contain granitoid intrusive rocks. Aeromagnetic data in Alaska and Yukon show that suites of plutons may have high, medium, low, or variable magnetic character (Hart and others, 2004b); parallel ilmeniteseries and magnetite-series intrusive-related gold belts have been mapped in Alaska and western Canada (Hart and others, 2004a). Hart and others (2004a) noted that the highest densities of intrusion-related mineral deposits are associated with the reduced and radiogenic ilmenite-series Fairbanks and Mayo suites, and not with the oxidized and primitive calc-alkaline magnetite-series rocks of the Nutzotin-Kluane belt. For our regional-scale RIRG analysis, we used a tilt derivative filter to enhance aeromagnetic anomalies (Miller and Singh, 1994; Verduzco and others 2004), which has been shown to be effective for RIRG analysis (Anderson and others, 2017), and constructed a scoring system to recognize cells in the magnetic data that are underlain by granitic rocks and have a negative magnetic score. Negative magnetic anomaly values were correlated with reduced, ilmenite-series intrusive suites as delineated by Ishihara $(1977,1981)$. Owing to the caveats mentioned above, we did not weight this dataset heavily. If a HUC contained cells showing negative magnetic values for granitic rocks, it received three points (table 6). Application of the aeromagnetic dataset to HUCs that contain granitoid intrusive rocks contributed one point towards the certainty score for that HUC (table 7).

\section{Results and Discussion}

Many areas identified by our GIS analysis that have high potential for reduced intrusion-related lode gold deposits contain known deposits and occurrences of RIRG-type systems, providing credibility to the scoring process. Some HUCs that have High potential for intrusion-related gold deposits are located adjacent to areas that contain ARDF records for lode gold, suggesting expansion of the known gold districts.

\section{Areas that have Known and Newly Recognized Prospectivity for Intrusion-Related Gold Deposits}

The intrusion-related model highlights areas underlain by intrusive rocks on the Seward Peninsula and in the southern Brooks Range, the Kokrines Hills belt, the Kuskokwim Mountains, east central Alaska, the Alaska Range, the Talkeetna Mountains, the Chugach Mountains, and southeastern Alaska 
(plate 4). Additional clusters of HUCs have High potential in areas that are not known to contain intrusion-related gold deposits. The main area that stands out in this respect contains HUCs near Selawik Hills (fig. 1; plate 4). The granitic intrusive rocks in this region are poorly characterized, and our results suggest further investigation is warranted.

\section{Northern Alaska}

Small, scattered, isolated HUCs show high prospectivity for RIRG in northern Alaska (plate 4), which correspond mainly with areas that contain Devonian and Precambrian intrusive rocks in the Brooks Range. Although granitic rocks are subordinate to rare in the southeastern Brooks Range, a cluster of high-prospectivity HUCs (fig. 1) corresponds to a well-known placer gold district (plate 2) and HUCs prospective for orogenic gold (plate 3 ). The overlap of gold associated with $\mathrm{As}, \mathrm{Sb}, \mathrm{Bi}, \mathrm{Te}$, and weak base metals for both deposit types is likely driving the overlap of the gold model prospectivity results in this area. Better quality data and sample density may help identify signatures in areas such as this in the future.

South of the Brooks Range in the Kokrines Hills area (fig. 1), mainly gold placer deposits are recorded in the ARDF, and lode deposits are sparse (plate 2). This area is underlain by a large composite batholith of middle Cretaceous age that includes both alkaline and peraluminous rocks at shallow to deep levels of exposure (Arth and others, 1989a,b; Miller, 1989). One deposit in this area consists of a felsic dike more than $15 \mathrm{~m}$ in thickness that contains a stockwork of quartz veins containing gold and base metals (Kurtak and others, 2002). The aeromagnetic database indicates the intrusive rocks in this batholith mainly have low magnetic values, suggesting potential for RIRG. The Cretaceous batholith postdates the Jurassic collision of an oceanic arc and a continental margin (Patton and Box, 1989; Roeske and others, 1995), and it is possible that the High-potential HUCs (plate 4) may reflect overprinting of early orogenic and later magmatic events. Careful evaluation of the geologic setting and geochemical characteristics in this area are required to understand whether this region is prospective for intrusion-related gold.

Parts of the Seward Peninsula in northwestern Alaska (fig. 1) are highlighted by this analysis as highly prospective for RIRG. No intrusion-related deposits are identified in ARDF records for this area; the known occurrences are characteristic of orogenic gold systems. Highlighted HUCs also overlap with those shown in the orogenic model (plates 3, 4). In the northern part of the peninsula, gold occurrences are located in veins that may be orogenic in derivation yet have anomalous bismuth relative to arsenic, which may reflect a genetic relation to a concealed pluton. Gold-bearing skarn deposits, including the Billiken prospect, in the contact zone of the Cretaceous Kugruk pluton, which is coincident with a significant aeromagnetic anomaly, may be genetically related to pluton emplacement. In the central part of the peninsula are mineralized vein deposits peripheral to Cretaceous plutons. Placer gold deposits near Cretaceous plutons in the Darby and Selawik Mountains and Zane
Hills lack identified lode sources (fig. 1; plate 2). Gold placer deposits peripheral to a middle Cretaceous quartz monzonite east of the Darby Mountains suggest a source associated with the stock, which includes hydrothermally altered rocks that contain $\mathrm{Au}, \mathrm{As}, \mathrm{Cu}$, and $\mathrm{Pb}$ (Miller and Elliott, 1969). In this area, argentiferous galena, sphalerite, pyrite, arsenopyrite, and minor chalcopyrite typically occur in quartz-tourmaline veins and disseminations in both intrusive rocks and hornfels; rock and soil samples in the area consistently contain high $\mathrm{Au}, \mathrm{Ag}, \mathrm{B}, \mathrm{As}$, $\mathrm{Cd}, \mathrm{Co}$, and $\mathrm{Cu}$ (ARDF no. CA-016). In the Selawik-Zane Hills trend, occurrences are dominated by quartz veins and veinlets showing variable amounts of silver, gold, base metals, pyrite, pyrrhotite, arsenopyrite, stibnite, and bismuthinite (Adams, 2007). Although many HUCs are highlighted as prospective for RIRG on the Seward Peninsula, granitic plutons are typically magnetite-titanite-bearing, indicative of oxidized igneous compositions.

Thus, the Seward Peninsula appears to be an area where characteristics between orogenic and intrusion-related gold systems are not sufficiently differentiated by the model parameters, and (or) the data quality and distribution are insufficient to differentiate the ore system types. More detailed geologic analysis should be undertaken in this region.

\section{East-Central Alaska}

In east-central Alaska, intrusion-related gold deposits are hosted in the variably deformed and metamorphosed continental fragment that underlies the Yukon-Tanana uplands (fig. 1). RIRG deposits in this area are best exemplified by the welldocumented Fort Knox deposit (McCoy and others, 1997) that produced 7.615 Moz of gold as of year-end 2017 (Athey and Werdon, 2018). In this deposit, gold occurs within and along the margins of quartz vein swarms within the middle Cretaceous Fort Knox granite body. Alteration in the system is strongly localized to vein selvages where sulfide contents are low ( $<0.1$ volume percent; Bakke and others, 2000) and dominated by bismuthinite, bismuth-tellurium sulfide (tetradymite and others), arsenopyrite, and pyrite (McCoy and others, 1997). Gold is strongly correlated with bismuth and tellurium (McCoy and others, 1997). The HUCs that have High potential are strongly correlated with known lode occurrences in east-central Alaska. A few light red, High-potential, Mediumto Low-certainty HUCs that lack ARDF localities are adjacent to the HUCs that contain known deposits, suggesting there may be additional undiscovered gold systems in this area.

The classification of the Pogo deposit, also in the YukonTanana uplands, remains controversial. The area around Pogo in this analysis is highlighted as prospective for RIRG deposits. Pogo is believed by some to represent an orogenic gold system (Goldfarb and others, 1997), whereas others believe that Pogo is an intrusion-related gold system (Rhys and others, 2003). The geologic setting is permissible for both deposit types (Selby and others, 2002). Mineralization within the Liese zone at Pogo is characterized by several stacked quartz veins emplaced into Paleozoic metamorphic rocks southwest of the Goodpaster 
batholith. The veins postdate the metamorphic deformation and postmetamorphic intrusions. The vein assemblage consists of quartz-pyrite-arsenopyrite \pm pyrrhotite \pm chalcopyrite $\pm \mathrm{Mg}$ - $\mathrm{Fe}$ carbonates accompanied by accessory fine-grained bismuthinite, native bismuth, native gold, galena, sphalerite, and molybdenite typically associated with RIRG (Rhys and others, 2003). Pogo thus exhibits characteristics of both mesothermal orogenic and reduced intrusion-related gold systems (Selby and others, 2002).

In addition to areas around Fort Knox and Pogo, the intrusion-related gold model shows high prospectivity and medium to high certainty in a belt extending from southwest of Livengood to the east-northeast (plate 4). This trend follows a broadly arcuate belt of middle to Late Cretaceous granitic plutonism. This belt is prospective owing to both its geochemical signature and geologic setting. Although HUCs primarily contain placer occurrences (plate 2), sparse lode occurrences contain keywords selected for the intrusion-related model in the ARDF. A small zone of high-prospectivity HUCs on the Alaska-Yukon border (plate 4) is spatially coincident with the middle Cretaceous Gardiner Creek plutonic suite and some Late Cretaceous porphyry mineral occurrences in the area, some of which are gold-rich skarn or distal disseminated gold styles of mineralization (for example, Tetlin; Illig, 2015). Other systems that appear to have RIRG characteristics, such as Road Metal and the Moosehorn Mountains, are located in this area.

At the western extent of the Yukon-Tanana continental fragment, Liberty Bell is characterized by silver-gold-copper occurrences associated with granitic porphyry dikes and stocks emplaced into metamorphic rocks (Yesilyurt, 1995). These occurrences consist of arsenopyrite-bismuthinite, bornite, and chalcopyrite. Alteration at the deposit is complex and dominated by quartz-sericite-clay assemblages. Smaller zones of carbonate-quartz, actinolite-pyrrhotite, chlorite-sericite-carbonate, and potassic (alkali feldspar-biotite-tourmaline with lesser allanite and quartz) alteration are also present in close spatial and temporal relation to gold-bearing occurrences (ARDF no. FB132). Liberty Bell sits near the center of a cluster of High-potential HUCs (plate 4) near the eastern margin of a belt of highly prospective HUCs associated with mainly felsic and lesser intermediate granitic intrusive suites emplaced in thickened continental crust, a primary geologic setting for RIRG systems. This area contains numerous ARDF occurrences highly prospective for orogenic and intrusion-related deposits (plates 3,4) and also has some element suites common to the porphyry environment. Although the sources of possible overlap are unclear, this belt certainly has the appropriate geologic setting, mineralogy, and geochemical signatures for RIRG deposits.

\section{Southwestern Alaska}

The Kuskokwim Mountains (fig. 1) contain deposits and occurrences that have ambiguous indicators and controversial classifications; many of these deposits have been variably classified as intrusive-related systems. These include the Vinasale, Von Frank, Golden Horn, and Donlin Creek systems. Shotgun, which is located between the Kuskokwim and western Alaska
Range belts, is the only unequivocal RIRG system in this region (Rombach and Newberry, 2001). The Shotgun deposit is in the Shotgun Hills, located in the southeasternmost parts of the Kuskokwim region (plate 4). The deposit is hosted within, and thought to be coeval with, a granite porphyry stock distal to the Shotgun Hills pluton (Rombach and Newberry, 2001). Mineralization is characterized by low-sulfide $(<1$ volume percent) stockwork, quartz-dominated veins containing gold-rich arsenopyrite with lesser pyrite, pyrrhotite, and chalcopyrite (Rombach and Newberry, 2001). Highly anomalous bismuth and tellurium are associated with the system and are present as native bismuth and bismuth- and tellurium-bearing sulfosalts. Alteration of the system is characterized by abundant sodic feldspar, quartz, and tourmaline with hydrolytic and carbonate-bearing assemblages present at the upper structural levels (Rombach and Newberry, 2001). These features are consistent with RIRG systems.

The classification of the world-class Donlin Creek deposit, which has a resource of $\sim 34 \mathrm{Moz}$ of gold (Athey and Werdon, 2018), remains controversial. This may reflect the overlap of contrasting styles of mineralization owing to overlap of discrete mineralizing events, or it may simply represent a hybrid deposit type. Donlin Creek is included in our intrusion-related gold deposit model owing to occurrences hosted within the presumed coeval intrusion and pathfinder element and mineral assemblages that fit the RIRG models. The deposit consists of a granite porphyry and a swarm of dikes, sills, and small stocks of basalt, rhyodacite about $5 \mathrm{~km}$ southeast of the granite that together have an age range of 71-65 Ma (Miller and Bundtzen, 1994); two styles of mineralization are recorded for these components of the deposit. The earlier mineralization is a higher temperature porphyry-style mineralization characterized by quartz veins that contain $\mathrm{Au}, \mathrm{Cu}, \mathrm{Zn}, \mathrm{Bi}, \mathrm{Ag}, \mathrm{Te}$, and $\mathrm{Se}$ at the Dome and Duqum prospects (McCoy and others, 1997; Szumigala and others, 2000). Alteration associated with this occurrence, characterized by sericite, illite, kaolinite, dickite, carbonate minerals, and pyrite, is primarily localized within the igneous rocks and does not appear to extend outward into the host rocks (Szumigala and others, 2000). Later low-temperature sheeted quartz, quartzcarbonate, and sulfide veins are dominated by arsenopyrite and pyrite, and associated stibnite, realgar, and native arsenic, accompanied by gold in the lattice structure of the arsenopyrite at the ACMA and Lewis prospects (Szumigala and others, 2000).

Vinasale is an intrusion-hosted deposit in the Kuskokwim region. This deposit is associated with brecciation in a biotitequartz monzonite (Dimarchi, 1993). There are three zones of gold occurrences, two of which are hosted in the breccia. Proximal magmatic brecciation events contain fragments of mineralized veins, indicating a coeval relation between magmatism and hydrothermal activity (McCoy and others, 1997). Gold is also hosted in peripheral quartz veins that contain arsenopyrite, pyrite, and traces of lead-antimony sulfosalts, stibnite, sphalerite, and galena; gold is refractory in the pyrite and arsenopyrite (Dimarchi, 1993).

The Upper Chicken Creek and Golden Horn deposits are examples of enigmatic stockwork occurrences within and peripheral to plutons. Mineralization is associated with 
biotite-tourmaline alteration of the plutons and quartz veins that contain native gold, stibnite, silver-sulfosalts, cinnabar, and minor chalcopyrite (Bundtzen and others, 1992). Slightly more than 2,700 oz of gold were produced from the Golden Horn deposit between 1922 and 1934; production from the Upper Chicken Creek lode deposit has not been distinguished from total Chicken Creek production that includes the placer mine (Bundtzen and others, 1992).

In the Kuskokwim region, we see a strong correlation between areas of known igneous-hosted occurrences and HUCs that show high prospectivity. Donlin Creek, Shotgun, and Golden Horn-Chicken Creek areas are all located in highly prospective areas (plate 4). Outside of those zones, a belt of High potential, Medium- to High-certainty HUCs is highlighted (plate 4). Many of these HUCs contain known placer occurrences, but relatively few lode occurrences identified in ARDF records have characteristics consistent with intrusion-related gold systems.

\section{Western Alaska Range}

The western Alaska Range, characterized by broad high prospectivity, is underlain by cyclic, predominantly calcalkaline, arc magmatism emplaced into sedimentary rocks that overlie the tectonically juxtaposed Farewell continental margin and Wrangellia-Peninsular ocean arc terranes. The western Alaska Range contains predominantly gold-rich porphyry copper deposits, such as Pebble (Lang and others, 2013), Whistler (Hames and others, 2012), and possible related epithermal parts of these separate systems, such as Terra (Porterfield, 2000), none of which are reduced systems. Other more enigmatic deposits such as Estelle have associations more characteristic of RIRG systems (Graham and others, 2013).

The porphyry copper systems in the western Alaska Range, exemplified by Pebble, contain significant gold. These are unequivocally porphyry systems associated with calc-alkaline arc magmas; they are quartz-dominated and sulfide-rich and have pyrite-chalcopyrite mineralization associated with potassic, hydrolytic, and advanced argillic styles of alteration. Alteration and ore are zoned around causative porphyry intrusions of granodioritic to monzonitic compositions (Lang and others, 2013). Mineralization is typically manifested in stockwork veins and disseminated in the host intrusive and surrounding wall rocks. The association of gold and base metals in these systems is a primary factor in identification of the highly prospective HUCs as gold-rich porphyry systems. Highlighted HUCs in this area may thus be indicative of other gold deposit types that are spatially coincident with this porphyry belt.

In contrast, Estelle consists of a composite of multiple ilmenite-series latest Cretaceous plutons emplaced into Upper Cretaceous flysch (Reed and Lanphere, 1972; Graham and others, 2013). Estelle is characterized by numerous structurally controlled, gold-bearing zones. Mineralized structures range from a few centimeters to nearly 20 -m-wide elliptical structures of closely spaced concentric fractures (Crowe and others, 1991). Gold occurs in quartz- and quartz-carbonate-dominant veins that contain chalcopyrite, pyrrhotite, arsenopyrite, pyrite, molybdenite, and gold (Crowe and others, 1991). Alteration is characterized by sericite- and albite-rich assemblages, most commonly as selvages to the veins (Graham and others, 2013, and references therein). The system contains bismuth and tellurium enrichments, similar to many RIRG systems. Estelle is somewhat controversial in its genetic classification; however, the association of gold with arsenopyrite, the presence of bismuth and tellurium, and the present, but relatively minor, base metal signatures are all consistent with RIRG systems. Based on these characteristics, our model for intrusion-related gold may accurately indicate high prospectivity for HUCs associated with this mineralizing system.

\section{Central and Eastern Alaska Range}

The central Alaska Range contains the Golden Zone deposit, which contains a resource of 303,300 oz of gold and $1.5 \mathrm{Moz}$ of silver (Athey and Werdon, 2018) and has many characteristics of RIRG gold systems. Golden Zone is located at the northeast end of the Chulitna-Yentna group of deposits. The Golden Zone is characterized by gold-silver-copper hosted in a quartz monzodiorite breccia pipe (Hawley and Clark, 1974; Gage and Newberry, 2003). Mineralization is characterized by shells of arsenopyrite- and chalcopyrite-rich zones surrounding a core of sulfide-poor, quartz-rich veined porphyry intrusive (Gage and Newberry, 2003). The system has associated bismuth and tellurium minerals, and arsenopyrite is the primary sulfide. Potassium-argon ages suggest mineralization was contemporaneous with plutonism at about $70 \mathrm{Ma}$ (Swainbank and others, 1977). Golden Zone has some characteristics such as the arsenic-bismuth-tellurium association, pyrrhotite, and intermediate depths defined by sphalerite geobarometry, consistent with RIRG systems (Gage and Newberry, 2003). The deposit also has characteristics such as (1) a copper-sulfide-dominant, quartzsericite-carbonate altered breccia pipe; (2) high grade coppergold veins; (3) strong potassic, biotite-potassium-feldspar alteration; (4) abundant chalcopyrite, sphalerite, and tetrahedrite; (5) a large temperature range for mineralization (Gage and Newberry, 2003); and (6) oceanic arc host rocks (Gilman and others, 2009) that are consistent with more oxidized porphyry systems. The Golden Zone sits in a cluster of highly prospective HUCs that extend outward more than $20 \mathrm{~km}$ from the deposit. Sparsely scattered felsic plutonic units through the belt have a strong spatial association to ARDF occurrences that scored in the moderate to high ranges for the RIRG deposit type. The Golden Zone intrusion was emplaced in a rear-arc position to the Alaska-Aleutian Range arc, coeval and along strike with the Mount Estelle pluton in the western Alaska Range, and coeval with the Willow Creek intrusive complex described above that is ascribed to the orogenic model. The debate over the type of hydrothermal system that produced the Golden Zone (Gage and Newberry, 2003) is likely the result of overlapping orogenic and back arc intrusion-related processes. Although it is unclear how best to attribute the prospectivity of the Golden Zone area, it has high prospectivity in the intrusion-related model. 


\section{South-Central and Southeastern Alaska}

In the Talkeetna and Wrangell Mountains, our analysis highlights a belt of High-potential, High-certainty HUCs in an area that is not known for lode gold deposits, although much of this belt includes placer mines and it is located on the southern flank of the Valdez Creek placer district. This part of the Talkeetna Mountains is underlain by a large volume of Triassic mafic volcanic rocks intruded by a Late Cretaceous to early Tertiary granite, granodiorite, and quartz monzodiorite intrusive complex to the southwest, a Middle to Late Jurassic granite, trondhjemite, and tonalite intrusive complex to the northeast, and transected by a north-northwest trending belt of Tertiary sodic rhyolite, alkaline basalt, and associated felsic dike swarms that extend northward to the Denali Fault (Wilson and others, 2015). In this area, a few occurrences and prospects are associated with the dike swarms that contain gold, silver, lead, and in one case, tellurium and mercury (ARDF no. TK088). Occurrences in ARDF records describe silicified granite that contains copper, zinc, and gold. Sparse prospects such as Old Gold (TK100 in https://ardf.wr.usgs.gov/; U.S. Geological Survey, undated) and Grizzly Butte (TK032 in https://ardf.wr.usgs.gov/; U.S. Geological Survey, undated) are located in mineralized diorite and granodiorite. Grizzly Butte consists of a porphyritic diorite stock that has strong potassic alteration, contains $\mathrm{Cu}, \mathrm{Mo}, \mathrm{Au}, \mathrm{Ag}$, and $\mathrm{W}$, and overlies a large magnetic anomaly inferred to indicate an underlying intrusive complex (TK032 in https://ardf.wr.usgs.gov/; U.S. Geological Survey, undated), or alternatively, Wrangellia basement (Saltus and others, 2007). These prospects are described as possible porphyry deposits based on their geochemical signatures and lie along strike with early Late Cretaceous plutons coeval with the Pebble porphyry (Bleick and others, 2012; Graham and others, 2013; Karl and others, 2015a). Their source and host rocks are poorly understood and poorly dated, making it difficult to distinguish early arc-related plutons, late transtensional intrusions, and overlapping orogenic systems. Rock and sediment geochemical signatures may be further complicated by an overprint related to the eruption of a Tertiary volcanic belt that may host epithermal-style deposits. This geologically complicated area is permissive for intrusionrelated gold deposits as well as other deposit types and is an area that warrants further investigation.

Lode gold deposits at Lucky Shot/Independence, Crow Creek, and Cliff, discussed in chapter 2, are in areas that have high potential, high confidence prospectivity for both orogenic (plate 3) and intrusion-related gold (plate 4). Both models highlight these areas as highly prospective owing to similar geochemical associations used in the models. These deposits are enigmatic because the gold-bearing quartz veins are very similar in age to the host plutons (Haeussler and others, 1995; Bleick and others, 2012; Karl and others, 2015a). Exploration in these districts should be conducted with an eye to both system types.

In southeastern Alaska, there is a strong spatial overlap between the belts determined to be highly prospective in the orogenic and intrusion-related models. The geologic setting strongly supports prospectivity for orogenic gold systems, including the Juneau gold belt, which may be overlapping older intrusion-related systems at Treadwell and Jualin (Newberry and Brew, 1987; Newberry and others, 1995; Miller and others, 2000), as discussed in detail in the previous chapter. The HUCs determined to be highly prospective for both models in the Juneau gold belt and on Chichagof Island (plates $3,4)$ likely reflect the strong overlap of geochemical characteristics between orogenic and RIRG systems, similar to the tectonic setting in south central Alaska as described above.

\section{Conclusions}

The GIS analysis for intrusion-related gold successfully highlighted areas of known RIRG occurrences such as in the Fort Knox-Pogo region and in western Alaska. Given the positive correlation of high-prospectivity HUCs identified in this analysis with known RIRG occurrences, high confidence is placed on HUCs within the model that show favorable prospectivity for gold. Although the analysis was conducted to assess prospectivity of reduced intrusion-related gold systems, it had difficulty differentiating RIRG from oxidized gold-rich porphyry copper systems. This is largely attributed to a lack of available data needed to identify the oxidation state of intrusive suites.

Significant overlap in areas that show high prospectivity for the RIRG and orogenic gold models is also apparent (plates 3,4). Although RIRG-highlighted areas are similar to those of the orogenic model, there are local differences in the distribution of High-potential HUCs. The overlapping pattern of the RIRG and orogenic models demonstrates our inability to definitively parse these system types with the available distribution, quality, and types of data.

Overlap between these ore systems is attributed to similar geochemical fingerprints, pathfinder assemblages, and similar geologic settings. Refining the model to account for overlapping geochemistry or conducting a focused district-scale analysis where a greater weight can be placed on geologic features that are beyond the resolution of the State scale analysis will enhance the analytical capabilities of the model. Such features to consider are structural controls, more detailed analysis of host rock characteristics, and association with thickened continental crust or proximity to orogenic belts in space and time.

\section{Chapter 4. Epithermal Gold Deposits}

Epithermal deposits generally develop from fluids associated with calc-alkaline to alkaline magmatism in volcanic arcs, as well as in intra-arc, back-arc, and post-collisional rift settings (Sillitoe and Hedenquist, 2003). Epithermal vein systems host precious and (or) base metal ores. Locally, the precious metal concentrations of epithermal deposits may achieve bonanza grades, which are $>1 \mathrm{Moz}$ of gold at $>30 \mathrm{~g} / \mathrm{t}$ (grams/ metric ton) of gold (Sillitoe, 1997). 


\section{Deposit Group Characteristics}

Epithermal gold deposits typically form within coeval volcanic rocks and are strongly structurally and host rockcontrolled in zones of high permeability. These systems form in the uppermost crust $(<2 \mathrm{~km}$ depth) at low temperatures $(<300$ $\left.{ }^{\circ} \mathrm{C}\right)$ (Simmons and others, 2005). Veins, or ore shoots, typically have steep dips and form in small-displacement, second- or third-order extensional or dilational structures. The ore shoots typically host the highest-grade ores and may be continuous for hundreds to thousands of meters laterally and tens to hundreds of meters vertically (Simmons and others, 2005). In comparison, disseminated zones are characterized by lower-grade, highertonnage ores that are stratigraphically controlled within breccias, coarse clastic rocks, or intensely altered rocks (Simmons and others, 2005). Quartz is the dominant gangue mineral and pyrite is the dominant sulfide mineral, ranging from $<1$ to $>20$ volume percent. Deposits and districts are variable in size, ranging from $<10$ to $\sim 2,000 \mathrm{~km}^{2}$ in aerial extent (Simmons and others, 2005). Globally, there is a spectrum of gold-rich $(\mathrm{Ag} / \mathrm{Au}$ ratio $<10)$ to Ag-rich (Ag/Au ratio 20-200) deposits; base metals are more commonly associated with the silver-rich systems. Some systems are copper-bearing, have high- to intermediate-sulfidation states, and contain abundant arsenic and antimony (for example, Yanacocha, Peru; El Indo, Chile; table 1). Most epithermal systems share a diagnostic suite of trace and pathfinder elements including $\mathrm{Hg}, \mathrm{Sb}, \mathrm{Te}, \mathrm{Se}$, and $\mathrm{Tl}$ (Simmons and others, 2005).

Diversity in precious and base metal mineral assemblages has led to various classification schemes within the epithermal clan of deposits. Many previous workers have recognized an association of ores with either high-sulfidation state or low-sulfidation state sulfide mineral assemblages (Bonham, 1986, 1988; Hedenquist, 1987; White and Hedenquist, 1990; John and others, 1999; Einaudi and others, 2003). The formation of epithermal deposits at shallow levels allows rapid oxidation and conversion to supergene minerals that render identification of their sulfide mineral assemblages nearly impossible. This difficulty has led some workers to classify the systems based on their gangue mineralogy, which include the quartz \pm calcite \pm adularia \pm illite and quartz+alunite \pm pyrophyllite \pm dickite \pm kaolinite types of systems (Simmons and others, 2005). These classifications reflect systems that form in near-neutral or acid solutions, respectively, and as such reflect characteristics of their geologic environments. Gold associated with the quartz \pm calcite \pm adularia systems is typically found in microscopic to submicroscopic grains of electrum or encapsulated telluride minerals. In contrast, gold associated with quartz+alunite systems is coarse grained and generally occurs as native gold and lesser electrum. The coarse native gold associated with quartz+alunite systems is more likely than the fine gold of the quartz-adularia systems to form placer deposits in areas of more extensive erosion.

\section{Mineral Resource Potential Estimation Method}

In our analysis for epithermal gold deposits, all datasets were considered. Scoring was weighted according to the ability of each dataset to help discriminate these deposits. Intense alteration is fundamental to this model, and because the type of rock that might host a gold-bearing epithermal deposit is not unique, the lithology database provides only a general indication of lithologic favorability through association with a hydrothermal source. The ARDF database, which includes data fields describing alteration mineralogy critical to classifying epithermal deposits, provides very strong indications for this type of deposit. Specific deposit types are often clustered in areas that have favorable geologic settings and, as with other deposit types, we limited the scoring of known deposits in order to avoid biasing results toward known districts and to address potential for undiscovered deposits. Placer records were not scored in the ARDF category and were instead combined with the heavy mineral dataset. Rock and sediment geochemistry carried the dominant weighting in our scoring process. HMC, having uneven coverage statewide, carried less weight than rock and sediment geochemistry. References to alteration, a critical component for identification and classification of epithermal gold deposit, are available in specific ARDF records and available at a general level in the nsalith database. This limited availability of alteration data is a major handicap in evaluating the epithermal deposit type, and we are considering ways to develop and access alteration data for regional mineral evaluation.

The current aeromagnetic compilation is of variable quality and may not be capable of imaging all parts of the epithermal system. Altered rocks that host epithermal deposits are not magnetic, and these rocks have a variable footprint that often cannot be recognized at the scale of our analysis. However, at a regional scale, epithermal deposits have a consistent correlation with magnetite-series intrusive rocks and associated hypabyssal and volcanic rocks.

The total possible points for potential for an epithermal gold deposit in a HUC in our analysis is 111 points (table 8). If all datasets contribute to the total score, rock and sediment chemistry can carry as much as 58 percent of that score, HMC data as much as 21 percent, lithologic data a maximum of 14 percent, ARDF records as much as 5 percent, and 3 percent for the association with magnetic hypabyssal and (or) intrusive rocks. Only the total score, statistically binned by the Jenks (1967) method, was used to determine High, Medium, or Low potential. The points and percentages that each dataset contributed to the total score for each HUC can be queried in ArcGIS and are tabulated in Karl and others (2021).

\section{Lithology}

For this model, points for lithology were given to HUCs containing rocks commonly associated with epithermal deposits. Altered rocks are the most important lithologic parameter; alteration is noted in unit descriptions in the nsalith database, but not precisely located. We used the association of alteration with hydrothermal sources such as shallow levels of magmatic systems and assigned five points to HUCs containing felsic volcanic and hypabyssal rocks in the nsalith table (appendix 3). Plutonic rocks of equivalent compositions, though indicative 
of favorable source magmas, may not have the close spatial association that is more commonly recognized with hypabyssal sources to epithermal mineralization, and were accordingly assigned three points. Lithologies favorable for epithermal deposits in a HUC were scored additively; HUCs in the epithermal model can receive a maximum of 16 points for appropriate rock types (table 8). Application of this dataset contributed one point toward the certainty score for a HUC (table 9).

\section{Alaska Resource Data File}

Deposit model keywords present in ARDF for the epithermal type include epithermal, Comstock, fumarolic, and Creedetype (tables 1, 14; appendix 2). Highly weighted ore and gangue mineral keywords important to epithermal systems include enargite, tetrahedrite, anhydrite, alunite, and adularia. Key alteration terms such as argillic and numerous variations thereof, vuggy, and variations of siliceous were also tallied. Many porphyryrelated keywords were assigned low or medium weight point levels for scoring, as the two deposit types typically occur together in the same districts. Keyword total bin scores for epithermal deposits are one point for totals of 15 to 29, three points for totals of 30 to 47, and five points for totals $>47$ (table 8). ARDF records that contributed to HUC scores contributed one point to the certainty score for a HUC (table 9).

\section{Rock and Sediment Geochemical Data}

As with the previous models, the epithermal potential model relies on the presence of gold and key pathfinder elements in the epithermal suite of minerals (As, $\mathrm{Sb}, \mathrm{Hg}$, Se, $\mathrm{Tl}$, Te). Metal ratios vary widely in epithermal systems (Lindgren, 1933); however, most epithermal systems share the same suite of trace elements (Simmons and others, 2005). Not all samples in the geochemical database were routinely analyzed for all elements that typify the epithermal suite. Only a small fraction of the total database contains data for all six pathfinder trace elements. Owing to this challenge, combinations of the various epithermal suite of elements were used to evaluate each HUC's potential without biasing the analysis owing to a lack of appropriate analytical data.

Scores for appropriate elements and pathfinder element combinations in rocks are additive. The presence of gold and silver in a rock received four to six points, coincident with the degree of anomalism above crustal background. The presence of $\mathrm{Hg}, \mathrm{Te}, \mathrm{As}, \mathrm{Bi}, \mathrm{Sb}$, or $\mathrm{Tl}$ at $>7.5$ times background results in a score from four to eight points (mercury or tellurium give scores on the high end and thallium on the low end). Rock geochemistry can contribute a maximum of 29 points to a HUC's total score for potential to contain an epithermal gold deposit (table 8). HUCs for which rock data are available received one point toward its certainty score (table 9).

Similar to the other models, sediment geochemistry was the primary tool for scoring the HUCs owing to good regional distribution of data. The presence of gold and silver in a HUC received 5 to 10 points, based on the degree of enrichment over background (table 8). The presence of As, $\mathrm{Bi}, \mathrm{Hg}, \mathrm{Sb}$, or Te contributed six or eight points, dependent on the degree of enrichment. The presence of thallium above 7.5 times background resulted in a score of four points. These points are additive; the stream sediment score can contribute a maximum of 35 points toward the overall score for potential for an epithermal gold deposit in a HUC. HUCs for which sediment data are available received one point toward the HUC certainty score (table 9).

\section{Heavy Mineral Concentrate Data}

Mineralogy and chemistry from HMC are incorporated into the gold potential scoring for epithermal deposits as a measure of the demonstrated presence of gold in a HUC. The dataset was combined with records for placer deposits in the ARDF. HUCs that contain a placer occurrence in the ARDF were assigned four points for the presence of gold; HUCs containing native gold or gold-bearing mineral phases in HMC were assigned three points; HUCs containing gold indicator minerals were assigned two points; and associated minerals related to epithermal gold systems were assigned one point. An additional two points were awarded to HUCs containing cinnabar or silver sulfosalts in the HMC dataset. The scoring was additive; the maximum possible score for the HMC mineralogy is 12 points (table 8 ).

HMC geochemical data were also used in our scoring system. HUCs were scored based on the presence of gold (four points), silver (two points), arsenic, bismuth, or antimony (two points), and mercury or tellurium (two points). An additional point was awarded to HUCs containing arsenic in combination with copper, lead, or zinc. Points are additive; the maximum possible score for HMC geochemistry is 11 points (table 8 ). Availability of HMC data in a HUC, regardless of whether the score was zero (that is, no minerals of interest present) or more (that is, minerals of interest identified), contributed one point to HUC certainty score; a lack of HMC data for a HUC - a null value - contributed no points to its certainty score (table 9).

\section{Aerial Magnetic Survey Data}

Aerial magnetic survey data were used on the State scale and filtered as described in the Introduction. Epithermal systems are characterized by pervasively altered rocks and are not magnetic. However, they are typically associated with oxidized calc-alkaline to alkaline magnetite-series (Ishihara, 1977, 1981) magmatic arc rocks. These rocks tend to have a moderately to strongly magnetic signature. At the deposit scale, zones of mineralization may be enveloped by areas of magnetic lows owing to the replacement of iron-oxide minerals by iron sulfides or other alteration products; however, the aeromagnetic data compilation is unable to distinguish nonmagnetic altered rocks from other nonmagnetic rocks at regional scales. Owing to the challenges inherent in application of the regional compilation of aerial magnetic surveys, we filtered the aeromagnetic data to more precisely 
locate aeromagnetic anomalies and enhance contrast between highly magnetic and poorly magnetic rocks (Anderson and others, 2017), and scored only cells containing hypabyssal and granitoid intrusive rocks in the nsalith database. HUCs containing cells that have positive magnetic values correlated with granitic or hypabyssal rocks were awarded three points for potential to contain epithermal deposits (table 8). Application of the aeromagnetic dataset for HUCs that contain granitoid or hypabyssal rocks contributed one point to the certainty score of a HUC (table 9).

\section{Results and Discussion}

Our analysis shows that HUCs having high scores for potential successfully identify a limited number of areas in Alaska known to contain epithermal gold deposits, as recorded in the ARDF. A wide distribution of HUCs shows Medium and High potential to contain epithermal gold deposits (plate 5), which indicates potential for epithermal systems may be $>$ previously appreciated, and (or) potential overlap with HUCs that have High potential for other gold deposit types (plates 1, 2, 6).

\section{Areas that have Known and Newly Recognized Prospectivity for Epithermal Gold Deposits}

Areas identified by the geospatial scoring process in this study as having high potential for epithermal gold deposits include the Alaska Peninsula, Kuskokwim Mountains, Alaska Range, Yukon-Tanana uplands, and southeastern Alaska (fig. 1; plate 5), in a pattern very similar to that of undivided types of gold deposits (plate 1). Known epithermal styles of mineralization occur on the Alaska Peninsula, western Alaska Range, and Yukon-Tanana uplands.

\section{Alaska Peninsula and Aleutian Islands}

The Alaska Peninsula and Aleutian Islands are underlain by Eocene to modern volcanic arc rocks, predominantly consisting of andesite and dacite. The Cenozoic volcanic rocks are subduction-related magmatic rocks that formed an arc that has been intermittently active for 60 million years. These rocks include calc-alkaline to tholeiitic plutonic and coeval volcanic edifices of the Eocene-Miocene Meshik magmatic arc and the late Miocene to younger Aleutian arc (Wilson, 1985; Wilson and Shew, 1992; Vallier and others, 1994). Mineralized veins are found in the Eocene to early Miocene andesitic volcanic rocks and less commonly in small intrusions and volcaniclastic rocks (Wilson and others, 1985).

The principal epithermal deposit of the Alaska PeninsulaAleutian Islands region is the Apollo Mine, which had production of $\sim 130,000 \mathrm{oz}$ of gold between 1892 and1922 from a lode extending 1,500 $\mathrm{m}$ along strike and $420 \mathrm{~m}$ vertically (Wilson and others, 1988). Other smaller lodes identified in the region have cumulative estimated reserves of 30,000 to 250,000 metric tons of ore grading between 250 and 575 ppm of gold (Wilson and others, 1988) and have had recent exploration (Athey and
Werdon, 2017). The mineralized systems are characterized by strongly structurally controlled quartz-dominant veins and vein breccias (Gray and others, 1997). Veins are commonly openspace fillings showing alternating bands of quartz-chlorite and sulfides. The principal ore minerals include gold, galena, sphalerite, chalcopyrite, pyrite, marcasite, arsenopyrite, and native copper (Wilson and others, 1988). Trace element geochemical signatures are characterized by the classic epithermal suite of elements, $\mathrm{Au}-\mathrm{Ag}$-Te-Pb-Zn-Mn-Cu and wide arsenic-mercury halos (White and Queen, 1989). HMC geochemistry indicates anomalous Ag, Pb, Zn, Au, and Sb (Frisken, 1992).

The epithermal prospectivity model accurately predicts high prospectivity in HUCs containing the known occurrences and deposits on the Alaska Peninsula and Aleutian Islands (plate 5). However, the sample density and data quality in this region likely result in underprediction of prospective HUCs. Access to the region is difficult owing to its remoteness, streams may be under sampled, and the active modern Aleutian arc has potentially concealed Eocene-Miocene epithermal systems beneath younger eruptive sequences. In particular, the northeastern Alaska Peninsula and the Shumagin Islands area shows high prospectivity for epithermal-style gold mineralization.

\section{Kuskokwim Mountains}

The Kuskokwim Mountains are highlighted as highly prospective for the epithermal model (plate 5). This region is known to contain epithermal veins dominated by mercuryantimony, and only trace gold associated with the ore systems. The veins have a close spatial association with Late Cretaceous and early Tertiary mafic to felsic intrusions emplaced in Upper Cretaceous Kuskokwim Group sedimentary rocks that overlie Precambrian to Paleozoic continental crust (Sainsbury and MacKevett, 1965; Decker and others, 1994). The small difference in age between the plutons and their host rocks indicates a common geologic setting and tectonic environment. The intrusive suite has a calc-alkaline to shoshonitic composition and trace element ratios that are characteristic of subduction-related arc rocks (Moll-Stalcup, 1994). These rocks locally have high $\mathrm{K}$ contents and variable initial ${ }^{87} \mathrm{Sr} /{ }^{86} \mathrm{Sr}$ that range up to values $>0.7080$, suggesting either crustal contamination or partial melting of the crust (Moll-Stalcup, 1994).

The main mercury-antimony lode deposits are localized along the contacts of the intrusive phases and the surrounding sedimentary host rocks (Sainsbury and MacKevett, 1965). Mineralization is characterized by open-space filling of veins and vein breccias, minor stockwork zones, and replacement bodies. The occurrences consist of cinnabar and stibnite plus less abundant realgar, orpiment, pyrite, native mercury, gold, and hematite (Gray and others, 1990). Hydrothermal alteration associated with the veins is indicated by hydrolytic to advanced argillic minerals such as sericite, dickite, and kaolinite. The veins and associated deposits are relatively small, and some mineralized veins contain anomalous concentrations of gold and silver (Gray and others, 1990). Gold has been identified in detrital cinnabar nuggets (Cady and others, 1955) and 
in heavy mineral concentrates of ores (Gray and others, 1990). The combination of mercury-antimony with anomalous gold in some of the occurrences may be indicative of the shallowest levels of the hydrothermal systems and concealed, higher-temperature gold-rich mineralization at deeper structural levels.

\section{Alaska Range}

In the western Alaska Range, areas of high prospectivity for epithermal gold systems are centered near Estelle, Terra, and Whistler prospects (plate 5). Although the region contains known occurrences classified as epithermal systems (Terra has been variably described, including as a quartz-adulariacarbonate epithermal vein, for example, Graham and others [2013]), the majority of the region is thought to be prospective for porphyry systems. One of the largest clusters of highprospectivity HUCs for epithermal systems contains the Whistler prospect, which is a gold-bearing porphyry system. The Estelle prospect also has high-prospectivity HUCs surrounding it but is enigmatic and exhibits characteristics consistent with reduced intrusion-related gold veins as well as a gold-bearing porphyry copper occurrence in the multiphase system (Graham and others, 2013). These observations in the western Alaska Range demonstrate that although high prospectivity is consistent with geology permissive for epithermal-style lode gold systems, there is significant overlap with known gold-bearing porphyry copper systems.

High-prospectivity HUCs extend northeastward from the western Alaska Range to the central Alaska Range (plate 5), including the area that contains the Golden Zone, which at $\sim 70 \mathrm{Ma}$ is similar in age to Terra at $\sim 68 \mathrm{Ma}$ and Estelle at $\sim 70 \mathrm{Ma}$ (Graham and others, 2013), and the common occurrence of intrusive bodies of this age along this trend (Wilson and others, 2015) is suggestive of a latest Cretaceous magmatic belt that may contain intrusive rocks at moderate to shallow levels of emplacement.

\section{Eastern Alaska}

In eastern Alaska, parts of the Yukon-Tanana uplands (fig. 1) are highlighted as prospective for epithermal gold systems (plate 5). For at least some parts of the region, evidence supports preservation of near-paleosurface structural levels from the middle Cretaceous through the present, compatible with the geologic environment prospective for epithermal systems. Caldera fill and related volcanic sequences are preserved in places such as the Middle Fork and South Fork calderas, which are located in the area slightly north of Tetlin (plate 5). Other mineral occurrences in the Yukon-Tanana uplands classified as likely epithermal systems include the Ptarmigan Hill, Silver Lining, Pika, and Pushbush showings (U.S. Geological Survey, undated; Allan and others, 2013). These occurrences consist of predominantly polymetallic veins that have base metalsilver \pm gold assemblages and abundant hydrolytic alteration. Ptarmigan Hill is hosted in Tertiary sedimentary rocks, Silver Lining and Pika are hosted in metamorphic rocks, and Pushbush is hosted in Paleocene-Miocene volcanic rocks. Locally, the veins consist of coarse barite-base metal concentration and minor gold. Extending laterally out from the veins are typically weak to moderate sericitic alteration assemblages. Preservation of these volcanic edifices and other nearby coeval volcanic rocks indicates that shallow levels of the crust have been preserved in the region, despite substantial Cenozoic tectonic modification by the Denali and Tintina strike-slip fault systems.

Other areas in eastern Alaska highlighted as prospective include the Livengood, Fort Knox, and Pogo Districts. These districts do not contain favorable geologic environments, nor known mineral occurrences exhibiting characteristics common in epithermal vein systems. Thus, the high prospectivity in these areas (plate 5) may be a result of an overlap of geochemical signatures between the intrusionrelated and epithermal models. Regardless of overlap, areas of high prospectivity for epithermal deposits coincident with preserved coeval volcanic rocks within the Yukon-Tanana uplands should be considered prospective for gold.

\section{Southeastern Alaska}

Many HUCs that show high prospectivity for epithermal gold in southeastern Alaska (plate 5) correspond closely with belts of known orogenic gold deposits that were highlighted by the orogenic model (plate 3). This is likely a result of similar pathfinder elements for these deposit types. Other areas in southeastern Alaska that show high prospectivity unique to the epithermal model are located in areas underlain by Eocene to Miocene volcanic rocks and hypabyssal intrusions of the Admiralty Island Volcanics on Kupreanof and Zarembo Islands (fig. 1), and granitic rocks of similar age west of the Chatham Strait Fault in the Skagway quadrangle (fig. 1; plate 5). The Admiralty Island Volcanics include felsic to mafic igneous rocks that have alkaline compositions (Ford and others, 1996) and associated stream sediment values high in arsenic, mercury, and antimony. Sheeted dikes, flows, domes, and pyroclastic rocks are common in this volcanic suite. Alteration in the form of silicification, kaolinization, and pyritization is locally strong and pervasive. On Kupreanof and Zarembo Islands, sparse ARDF localities record occurrences of chalcedony and quartz in rhyolite locally rich in fluorite; associated with $\mathrm{Au}, \mathrm{Ba}, \mathrm{Ce}$, and $\mathrm{La}$; and felsic dikes that contain arsenopyrite, magnetite, and copper-, lead-, and zinc-sulfides.

\section{Conclusions}

The epithermal analytical model indicates the presence of high-prospectivity HUCs that correlate well with the regions of known epithermal systems. These regions have experienced tectonic quiescence since the time of volcanic and hydrothermal activity. The model identified a large region of the Kuskokwim Mountains that may represent the shallowest levels of concealed gold-rich epithermal-style mineralization. Difficulties arise in differentiating the epithermal systems 
from gold-rich porphyry systems. Quartz+alunite \pm pyrophyll ite \pm dickite \pm kaolinite type epithermal systems may transition to porphyry systems at depth and thus may have overlapping geochemical characteristics.

The epithermal analysis shows considerable overlap with the orogenic gold model, particularly in eastern and southeastern Alaska. This is likely related to overlapping pathfinder elements. District-scale analysis would be required to carefully distinguish differences in the geochemical and geologic parameters of the model to successfully differentiate from the porphyry and orogenic models.

\section{Chapter 5. Discussion of Discrimination of Lode Gold Deposit Types}

Distinguishing between orogenic, intrusion-related, and epithermal gold systems in these GIS-based prospectivity analyses has proven to be difficult with available data. Geochemical signatures combined with lithology are the most powerful factors for discriminating among these systems; subtle differences in these variables with respect to deposit type reflect the underlying geologic settings in which the ore systems form. Ranges of values for parameters used to define deposit types, such as hypabyssal versus shallow intrusive emplacement depth distinctions between epithermal and intrusion-related models, are difficult factors to quantify with discrete boundaries for scoring strategies. Arsenic, antimony, and mercury are common pathfinder elements in hydrothermal gold systems, and the presence of $\mathrm{Bi}, \mathrm{W}, \mathrm{Tl}, \mathrm{Te}, \mathrm{Se}, \mathrm{Mo}$, and (or) base metals in various combinations helps to distinguish these systems (for example, Lang and Baker, 2001; Goldfarb and others, 2005; Simmons and others, 2005) but complicates binning of values that define these parameters.

As discussed in chapters 1-4 herein, we observed significant overlap using available data to distinguish the main conventional classifications of lode gold deposit types. In part, this is due to a reliance on the relative enrichments of $\mathrm{Au}, \mathrm{Ag}$, $\mathrm{As}, \mathrm{Sb}$, and (to a lesser extent owing to limited available data) $\mathrm{Hg}$ over background in the sediment and rock geochemical databases. These pathfinder assemblages are ubiquitous in the systems and cause a significant amount of overlap. Adding to the difficulties are the presence of some of the other pathfinder elements in multiple system types. For instance, tungsten and bismuth may be associated with orogenic and intrusion-related systems. Base metals are present in the periphery of some intrusion-related and epithermal systems.

Additional sources of overlap are inherent in the geochemical database. Samples within the AGDB3 were not systematically analyzed for trace phases, and many analyses are outdated or contain emission spectroscopy semiquantitative data. For example, most samples in the database do not contain analytical results for the entire suite of characteristic epithermal elements; they often only contain data for $\mathrm{Au}, \mathrm{As}, \mathrm{Sb}$, and $\mathrm{Ag}$ and have sporadic $\mathrm{Se}, \mathrm{W}, \mathrm{Hg}$, or
Te data. Analytical data for many samples in the database are limited to semiquantitative stepwise techniques which often have high minimum detection limits. For these techniques, detection limits may be as much as 3.5 times background for a given element. As a result, a value near the minimum detection limit of the analysis, which has a high degree of uncertainty, can yield a moderately anomalous value in the scoring rubric for the models.

Within the intrusion-related model, it is very difficult to segregate RIRG systems from the generally more oxidized, gold-bearing porphyry copper systems. One of the primary reasons for the overlap in our analysis is the difficulty of determining the oxidation state of the associated intrusive rocks. The AGDB3 inconsistently contains iron titration data, and the State geologic map unit descriptions are not sufficiently detailed to confidently characterize the oxidation state based on igneous mineral assemblages. Additionally, both gold-bearing porphyry systems and reduced intrusion-related gold systems form in similar intrusive rock types. Associated copper, molybdenum, base metals, and bismuth pathfinders may be present in both system types (Lang and Baker, 2001; Seedorff and others, 2005). Although the classic RIRG fingerprint is characterized by gold-bismuth-tellurium (Lang and Baker, 2001), tellurium data are not widely reported in the database. Owing to the limits of available data for our analyses, gold-bearing porphyry systems and RIRG systems are both likely to achieve high scores in the intrusion-related model.

The overlap of different styles of gold mineralization in space and time also complicates the ability to uniquely differentiate the prospectivity of regions for the different models. Prospectivity maps are generated utilizing the timeintegrated snapshot of geologic processes preserved on the modern surface. Thus, some of the perceived overlap in the geochemical signatures likely reflects the superposition of multiple geologic events through time. The Tintina gold belt in eastern Alaska is a region in which a protracted history of mineralization that includes all three deposit types is documented (for example, Allan and others, 2013; Kreiner and others, 2019). Such overlap and potential superposition of different geologic environments have made it difficult to come to a consensus on the genesis of major gold deposits, such as Pogo, in the region (Goldfarb and others, 2001, 2005; Rhys and others, 2003).

\section{Method to Evaluate Deposit Model Overlap}

Many HUCs received medium or high mineral potential scores for more than one deposit type. Using a custom Python script in ArcGIS, the degree of overlap of mineral potential for multiple deposit types was quantified for each HUC. In this section, we describe an exercise to calculate overlap between the orogenic, intrusion-related, and epithermal deposit groups.

During this secondary scoring process for HUCs, every attempt was made to keep the maximum scores of the different analyses as close to equal values as possible. Owing 
to the different geochemical and geological characteristics of the various deposits, it was impossible for the analyses to have the same maximum score. Thus, prior to calculating the overlap between orogenic, intrusion-related, and epithermal gold deposits, their total scores were normalized to a common scale. To prevent individual normalized HUC scores from exceeding the scale, the highest total score of the three models (111 for epithermal) was used as the normalization factor. Overlap was calculated using the following equation:

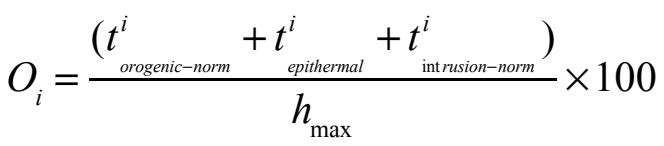

Here, $t^{i}$ is the total score for a given model for HUC $i$, and $h_{\max }$ is the total score of the highest-scoring HUC in all three datasets; in this case, it is 111 in the epithermal model. The calculation results in a possible range of $0-300$ percent for mineral potential overlap. For example, a hypothetical HUC that receives the highest actual score in each of the three deposit types would be assigned an overlap of 300 percent, whereas a HUC that receives the highest actual scores in any two deposit types would have 200 percent overlap. HUCs that have overlap values from 100 to 200 percent scored for High potential for only one deposit type and Medium potential for the other deposit types, or Medium potential for all three deposit types. Overlap values less than 100 percent generally indicate HUCs that have Low potential for one or more deposit types and no high-potential scores.

\section{Results and Discussion}

The results of the application of the overlap exercise for orogenic, intrusion-related, and epithermal gold deposits are shown on plate 6 . The overlap is strong in all of the main areas that scored high for lode gold potential in Alaska. Areas showing the darkest colors have overlap scores higher than 200 percent and contain most of the main lode deposits that are known in Alaska. Such high overlap indicates that all three models scored for medium to high potential in these areas.

Adjacent HUCs showing lighter colors have overlap scores that range from 100 to 200 percent, indicating Medium potential for all three deposit types, or a combination of High and Medium potential. A detailed examination of specific regions reveals that high overlap results largely from the high weight of geochemistry, in particular a reliance on gold and silver geochemistry in our analyses, and partly because of the temporal and spatial overlap of geologic setting as described above. For example, the HUCs around Apollo score high mainly because of geochemical signatures, principally gold and silver, common to all models, yet it is unlikely the active Aleutian volcanic arc is prospective for orogenic gold. The opposite scenario is apparent in the Nome District, which contains Nome and Rock Creek (fig. 1; plates 1-9); the district is known to be prospective for orogenic gold systems, but also scores high potential for epithermal systems because of similar geochemistry. On the other hand, spatial-temporal superposition of multiple deposit types is documented in the Yukon-Tanana uplands region (Allan and others, 2013), and consequently the overlap indicated there (plate 6) may reflect overprints of geologic settings. It is possible that some of the overlap in this region is also caused by geochemical parameters. The high degree of overlap serendipitously showcases the sources of debate over deposit-type classification for many of these deposits in Alaska.

Using the parameters available for our analyses, the overlap empirically observed, tested by calculation, and shown on plate 6, decidedly inhibits targeted exploration for the three conventionally defined deposit types. An alternative approach might classify these deposits differently and result in better success for targeted exploration. Although orogenic, intrusion-related, and epithermal deposits have substantial overlap in trace element signatures, in detail, orogenic and RIRG systems have strong similarities and differ substantially from epithermal systems. A different approach, such as discriminating between ore-forming environments, may be more productive. Using parameters specific to ore-forming environments, orogenic and reduced intrusion-related gold systems form in more reduced environments, in overly thickened crust, and (or) during the waning stages of orogenic development; whereas epithermal and gold-bearing porphyry systems form in more oxidizing environments associated with calc-alkaline magmatism principally in continental subduction-related arc settings. Such conditions will influence the composition of pathfinder element suites. Our attempt to use the data available to distinguish gold deposits with a focus on the factors affecting the hydrothermal systems are described in the following two chapters. Overlap between these two groups is discussed in chapter 8 .

\section{Chapter 6. Gold-Bearing Porphyry and Epithermal Gold Deposits}

Owing to the difficulty in distinguishing the three conventional lode gold deposit types found in Alaska utilizing similarities and differences derived from available datasets, we grouped gold deposits with respect to the main characteristics of their ore-forming environments and looked for distinguishing features that could be evaluated with our data. Epithermal gold systems and gold-bearing porphyry systems have important commonalities. Globally, epithermal and porphyry systems often occur in the same districts, where they share geologic settings and element associations (Muntean and Einaudi, 2001; Maydagán and others, 2015). These magmatic-hydrothermal systems commonly form in calc-alkaline to alkaline hydrous magmas in volcanic arcs at convergent plate boundaries (for example, Sillitoe, 1973, 1997; Gustafson and Hunt, 1975; Sawkins, 1990; Hedenquist and Lowenstern, 1994; Tosdal and Richards, 2001; Sillitoe and Hedenquist, 2003).

Porphyry gold systems, such as those found in the Maricunga belt of northern Chile (for example, Lobo; Muntean and Einaudi, 2000, 2001; table 1, this report) are not known in 
Alaska. Alternatively, many copper- and molybdenum-dominant porphyry systems in Alaska contain minor to significant gold endowments (Bouley and others, 1995; Young and others, 1997; Kelley and others, 2013; Goldfarb and others, 2016). Copperdominant porphyry systems in Alaska such as the Pebble porphyry copper(-gold-molybdenum) deposit (Bouley and others, 1995; Lang and others, 2013) are not the primary focus of this prospectivity analysis; however, porphyry systems are included here owing to the close spatial and temporal relation between high-temperature porphyry environments and lower-temperature epithermal systems, manifested principally by the quartz-alunite-pyrophyllite-dickite-kaolinite hydrothermal systems.

\section{Deposit Group Characteristics}

Gold-bearing porphyry and epithermal gold systems share many characteristics. A primary characteristic is the element association of abundant copper, gold, and sulfur (Heinrich, 2005). Other characteristics such as alteration assemblages can have gradational transitions between deposit types. Epithermal deposits can be broken into multiple classifications, the specific characteristics being determined by the ore-forming environment. For this analysis of gold prospectivity, we used the classification of Simmons and others (2005) based on the hypogene gangue mineralogy. Systems are characterized by the presence of quartz-calcite-adularia-illite and quartz-alunite-pyrophyllitedickite-kaolinite alteration assemblages. Generally, the former is most common in a geothermal environment, whereas the latter is more common in a magmatic-hydrothermal or active volcanic environment. Hydrothermal alteration is also an important guide to ore in porphyry systems, because it commonly forms well-developed zoning patterns. These patterns include, as a function of early high temperatures, feldspar-stable assemblages transitioning vertically and laterally into lower-temperature hydrolytic assemblages. Alteration may be present over significant volumes of rock $\left(>10 \mathrm{~km}^{3}\right)$ and present within the causative intrusions, extending into adjacent rock and transitioning to epithermal systems (Seedorff and others, 2005).

Gold-rich porphyry copper systems and porphyry gold deposits are commonly found in rocks of granodioritic to dioritic composition. Intrusions associated with ore are typically small-volume $\left(<0.5 \mathrm{~km}^{3}\right)$ dikes and plugs that were emplaced at (shallow) depths of 1-6 km (Seedorff and others, 2005) and are commonly part of a larger batholith. Porphyry systems tend to form in clusters within or above cupolas on the roof of an underlying intermediate to silicic intrusion. Intrusions are commonly oxidized and have magnetite-titanite as primary accessory phases (Seedorff and others, 2005).

\section{Mineral Resource Potential Estimation Method}

During our analysis for epithermal and gold-bearing porphyry deposits, all datasets were used. To focus the GIS process on this ore-forming environment, we limited this analysis to HUCs that yielded medium- or high-prospectivity scores in the undifferentiated lode gold prospectivity model (plates 1,7 ). The commonalities of the epithermal and gold-bearing porphyry deposit types and characteristics that distinguish them from other deposit types were identified. Scoring was weighted according to the ability of each dataset to discriminate these factors.

The model for this ore-forming environment is favored by felsic or intermediate hypabyssal and plutonic rocks. The geologic map database also contains specific information about the distribution of alteration and alteration mineralogy that can be searched using keywords. ARDF database records provide very strong indications of specific types of mineralization and information on gangue minerals and alteration mineralogy that can be scored using keywords. As noted in previous chapters, we limited the scoring of known deposits to avoid biasing results toward known districts and to address potential for undiscovered deposits. Rock and sediment geochemistry are the most efficient datasets for locating target elements and carry the dominant weighting in this scoring process. Owing to uneven statewide coverage, the HMC dataset carried less weight than rock and sediment geochemistry. Aeromagnetic data are comprehensive statewide, and appropriate filters help recognize the intrusive rocks in this model that tend to contain magnetite.

The total possible points for resource potential in the combined epithermal and gold-bearing porphyry deposits in our analysis is 97 points (table 10). If all datasets contribute to the total score, rock and sediment chemistry can carry as much as 64 percent of that score, HMC data as much as 15 percent, lithology as much as 12 percent, ARDF records as much as 6 percent, and magnetic data a possible 3 percent of the total score for a HUC. Only the total score, statistically binned by the Jenks (1967) method, was used to determine High, Medium, or Low potential. The points and percentages that each dataset contributed to the total score for each HUC can be queried in ArcGIS and are tabulated in Karl and others (2021).

\section{Lithology}

Epithermal and porphyry systems can be spatially and temporally related. Thus, rock types that have favorable indicators for porphyry system potential may also indicate quartz-alunitepyrophyllite-dickite-kaolinite epithermal potential. The combined gold-bearing porphyry and epithermal gold deposit group model therefore incorporates the favorable felsic or intermediate hypabyssal and plutonic rocks for the epithermal class model described in chapter 4 but differs from the epithermal-only model by giving an equal weight of three points to all of these rock types (table 10, appendix 3 ). This dataset is additive, yielding a maximum possible score of 12 points, and contributes one point to the certainty score of a HUC (table 11).

\section{Alaska Resource Data File}

ARDF records were searched and scored for keywords relevant to epithermal and porphyry gold \pm copper \pm molybdenum deposits. Deposit model, ore and gangue mineral, and alteration 
field keywords are similar to those used in the intrusion-related and epithermal models described previously. Additionally, porphyry and related skarn deposit models, including model numbers 18a, 18b, 18d, 21a, and 21b of Cox and Singer (1986), were assigned high weight. Gold (or other variations of gold) was only given high weight in the deposit model field of the ARDF database and not scored in the ore minerals and alteration fields to eliminate overscoring resulting from numerous mentions in a single record. Keyword totals of $0-12,13-28$, and $>28$ were binned for representative ARDF scores of one, three, and five points, respectively (table 10). Application of this dataset contributed one point to the certainty score of a HUC (table 11).

\section{Rock and Sediment Geochemical Data}

Rock geochemistry was scored similarly to scoring in the previous models, utilizing multiples of the background concentrations of the elements of interest to determine anomalies as described in Smith and others (2013) and listed in appendix 1 . Scores were then applied based on the degree of anomalism for an element or suite of elements (table 10). The major difference between the epithermal model in chapter 4 and this analysis is the utilization of gold and silver. It was determined in the previous models that relying on gold and silver enrichments was partly responsible for the overlap between different systems. This model utilizes only HUCs that have already been highlighted in the undifferentiated lode gold model (plate 1) as having medium or high prospectivity for lode gold deposits. The undifferentiated model considers enrichments of gold and silver to determine the prospectivity (table 2). To reduce the overlap with the reduced intrusion-orogenic gold model (chapter 3), tungsten is used to help distinguish the geochemical signatures. To enhance contrast between the models, samples that contain tungsten more than 3.5 times background (appendix 1) are not considered in the epithermal-porphyry model. For example, a sample containing As, Hg, Se, or Te is only scored in the epithermal and gold-bearing porphyry model if it does not contain tungsten at $>3.5$ times background (table 10).

Elements selected for the rock geochemistry score include the standard epithermal suite of pathfinder elements: As, $\mathrm{Sb}, \mathrm{Hg}$, $\mathrm{Se}, \mathrm{Te}$, and $\mathrm{Cu}$. Owing to the limited number of samples within the geochemical database containing analyses for the entire suite of pathfinder elements, the scores rely most heavily on As, $\mathrm{Sb}, \mathrm{Hg}$, and $\mathrm{Cu}$. The rock geochemistry score, which is additive as noted in table 10, has a maximum possible score of 27 points for a HUC. Application of this dataset contributed one point to the certainty score of a HUC (table 11).

In the gold-bearing, porphyry-epithermal gold model scores were not applied for gold and silver from sediment geochemistry (table 8). Once again, this model scores only HUCs previously determined to have prospectivity for undifferentiated lode gold occurrences, and scores for gold and silver for rock and sediment chemistry were applied in that analysis. The scoring strategy for sediment chemistry in this analysis was the same as that for rock chemistry utilizing a geochemical suite of elements that includes As,
$\mathrm{Sb}, \mathrm{Hg}, \mathrm{Se}, \mathrm{Te}$, and $\mathrm{Cu}$ (table 10). As is also the case for the rock geochemistry, a limited number of samples in the database have been analyzed for the entire pathfinder suite of elements. Sediment scores are additive as detailed in table 11 and contribute a maximum possible score of 35 points for a sample. Application of this dataset contributed one point to the certainty score of a HUC (table 11).

\section{Heavy Mineral Concentrate Data}

Heavy mineral concentrate data were used similarly to their application in the epithermal model. HMC geochemical data are available for a select suite of the pathfinder elements such as $\mathrm{As}, \mathrm{Bi}, \mathrm{Sb}, \mathrm{Te}, \mathrm{Cu}$, and Mo (table 11). This geochemistry was scored according to typical background concentrations in the AGDB (appendix 1) to indicate anomalous pathfinder elements as discussed in Smith and others (2013). The scores for geochemical values are additive, contributing a maximum of three points toward the total possible score for HMC data for a sample in a HUC (table 10).

For HMC mineralogy, points were assigned for (1) high-sulfidation state copper minerals characteristic of the magmatic-hydrothermal epithermal environment; (2) molybdenite, which indicates favorable porphyry environments; and (3) silver-bearing sulfosalts characteristic of the geothermalstyle epithermal systems (table 10). One point was awarded for the presence of common copper and molybdenum minerals, whereas two points were awarded for minerals more commonly associated with epithermal veins, such as the silver sulfosalts and high-sulfidation state copper minerals (table 10). Mineralogy points are additive and contribute a maximum of 12 points to the total possible 15 points for HMC for a HUC. Application of this dataset contributed one point to the certainty score for a HUC (table 11).

\section{Aerial Magnetic Survey Data}

Aeromagnetic data at the state scale were used as described in the Data Types and Analytical Process section in the Introduction. Owing to the challenges inherent in the application of the regional compilation of aerial magnetic surveys, we filtered the aeromagnetic data to more precisely locate aeromagnetic anomalies and enhance contrast between highly magnetic and poorly magnetic rocks (Anderson and others, 2017), and scored only cells containing hypabyssal and granitoid intrusive rocks in the nsalith database. As previously discussed, epithermal and gold-bearing porphyry systems are typically associated with oxidized calc-alkaline, magnetiteseries (Ishihara, 1977, 1981) magmatic arc rocks. HUCs that contain cells that received positive magnetic values in filtered aeromagnetic data tied to granitic rocks were assigned three points for potential to contain oxidized-porphyry and associated epithermal deposits (table 10). Application of this dataset for HUCs that contain granitoid rocks contributed one point to the certainty score of a HUC (table 11). 


\section{Results and Discussion}

HUCs shown to be highly prospective for gold-bearing porphyry and epithermal gold systems are similar to patterns determined in the epithermal analytical model (plates 5, 7). Although the distribution is similar, the percentage of highpotential relative to Medium-potential HUCs is narrowed, likely a result of tighter constraints in the scoring process for the combined analysis.

Areas identified by the geospatial scoring process in this study that have high potential for gold-bearing porphyry and epithermal gold deposits and occurrences include the Alaska Peninsula, Kuskokwim Mountains, Alaska Range, and Yukon-Tanana uplands of eastern Alaska (plate 7). Other areas of interest highlighted by this model include the southern Seward Peninsula, the eastern Brooks Range, and parts of southeastern Alaska.

\section{Areas that have Known Prospectivity for Gold- Bearing Porphyry and Epithermal Gold Deposits}

This model is in good agreement with the locus of known epithermal and gold-bearing porphyry systems. Highlighted areas along the southern coast of the Alaska Peninsula and in the Shumagin Islands match well with known epithermal deposits and occurrences such as Apollo. The model shows slightly enhanced high prospectivity on plate 7 relative to plate 5 in this area. The dark-colored HUCs indicate high confidence based on contributions from most or all datasets. The sparse distribution of high-prospectivity HUCs may reflect young volcanic cover and ash, or scarce available data, and does not preclude potential in areas that indicate low certainty.

The Kuskokwim Mountains in southwestern Alaska are highlighted by medium to high prospectivity. This region consists of mercury-antimony occurrences indicative of shallow geothermal environments, which may be the upper parts of underlying gold-rich hydrothermal systems. The number of highly prospective HUCs are more limited in this model (plate 7) relative to the epithermal model (plate 5), most likely a result of increased emphasis on pathfinder elements. The southwestern Kuskokwim Mountains are shown to have a greater aerial extent of high-prospectivity HUCs in comparison to the northeastern Kuskokwim Mountains, which have scattered high-prospectivity HUCs within a field of extensive medium-prospectivity HUCs.

In the western Alaska Range, areas of high prospectivity are centered near Estelle, Terra, and Whistler (plate 7). Whistler is a gold-bearing porphyry system, and Terra has been variably described as a quartz-adularia-carbonate epithermal vein (for example, Graham and others, 2013). Estelle is enigmatic and exhibits characteristics consistent with reduced intrusion-related gold veins as well as a gold-bearing porphyry copper occurrence in the multiphase system (Graham and others, 2013). As is the case with the Alaska Peninsula and Aleutian Islands, the western Alaska Range represents a geologically prospective terrane, and generally has sparsely clustered high-prospectivity HUCs within a more extensive region of medium-prospectivity HUCs.
The central and eastern Alaska Range also show localized areas of high prospectivity within extensive areas of mediumprospectivity HUCs. The high-prospectivity HUCs are mainly clustered around areas of known gold occurrences. Although gold-bearing porphyry and epithermal gold systems are uncommon in this region, the geology is locally favorable. Mixed medium- and high-prospectivity HUCs in the Talkeetna Mountains (fig. 1) are underlain by bimodal Paleocene to Miocene volcanic rocks that include dike complexes, stocks, flows, and pyroclastic deposits of latite, quartz latite, and rhyolite compositions, overlain by andesite and basalt flows. Small clusters of high-prospectivity HUCs in the northern Wrangell Mountains (fig. 1) contain sparse felsic plutons, including middle Cretaceous granodiorite at Orange Hill that contains a weakly goldbearing, porphyry copper-molybdenum deposit (Richter and others, 1975). A southern cluster coincides with the fairly extensive Miocene to Quaternary Wrangell volcanics that contain active fumaroles. These young volcanic rocks overlie mineralized carbonates and greenstones that contain middle Cretaceous granodiorite bodies. The trace element signature in this region may also reflect spatial overlap of Cenozoic hydrothermal systems with carbonate-hosted, copper-rich occurrences of Mesozoic age such as the Kennecott-type deposits (which generally lack gold).

East-central Alaska has had little exhumation since the Mesozoic and is prospective for epithermal and gold-bearing porphyry deposits of Early Cretaceous through Miocene age. Despite the favorable geologic setting, the model shows more limited high-prospectivity HUCs within aerially extensive medium-prospectivity HUCs in plate 7 relative to the distributions on plate 5 . The high-prospectivity HUCs correspond well with known porphyry and epithermal mineral occurrences yet overlap with other gold deposit models can be observed. For example, the Fort Knox, Livengood, and Pogo reduced intrusion systems are located in clusters of HUCs that have high prospectivity for gold-bearing porphyry and epithermal gold systems (plate 7). This demonstrates the persistent difficulty in differentiating the various gold systems based on geologic and geochemical characteristics.

\section{Areas that have Newly Recognized Prospectivity for Gold-Bearing Porphyry and Epithermal Gold Deposits in Alaska}

Regions not previously identified as containing goldbearing porphyry or epithermal gold systems are also highlighted by the study. Parts of the southern Seward Peninsula, eastern Brooks Range, and southeastern Alaska are highlighted as having prospectivity in the analysis for this combined model. Further investigation is required to determine whether these regions are correctly or incorrectly recognized for gold-bearing porphyry and epithermal gold system prospectivity. In all three places, the geologic setting is more favorable for orogenic gold and reduced intrusionrelated gold systems, and all three areas are underlain by metamorphosed older basement containing previous mineral 
deposits that could complicate the trace element signature. There is a relatively poor correlation of high-prospectivity HUCs in these areas with hypabyssal or felsic granitic plutons in this region. One exception is in the southern Brooks Range where high-prospectivity HUCs correlate with (Devonian) felsic to intermediate volcanic rocks. These regions thus highlight significant overlap of gold-bearing, porphyry-epithermal gold systems with the orogenic and intrusion-related gold systems discussed in chapters 2 and 3, despite our various approaches to distinguish the different deposit types.

\section{Conclusions}

The combined model correlates closely with areas of known gold-bearing porphyry and epithermal gold systems, particularly highlighting the Alaska Peninsula-Aleutian Islands and western Alaska Range. Grouping the gold-bearing porphyry and epithermal gold environments for this model allows better discrimination of these deposits from other lode gold deposit types. However, considerable overlap with orogenic and reduced intrusion-related gold systems remains, largely owing to the overlap of pathfinder geochemistry related to gold mineralization and a general lack of trace element analyses in AGDB3 within the epithermal pathfinder suite. Enhancement of the other datasets by the addition of new data, development of better tools to access data, and creation of an additional dataset to track alteration could improve the robustness of analyses for this deposit model and perhaps the component deposit types within it. Although this model yields high confidence in regions in Alaska deemed to be highly prospective for gold-bearing porphyry and epithermal gold systems, detailed analysis of the geologic environment on a mining district or mountain-belt scale will help further refine the datasets and distribution of highly prospective HUCs.

\section{Chapter 7. Reduced Intrusion-Related and Orogenic Gold Deposits}

Reduced intrusion-related gold and orogenic deposits tend to form in similar ore-forming environments during the waning stages of orogenic collisional events and may overlap in time and space. The overlapping geochemical characteristics, similar compositions of hydrothermal fluids, and geologic settings make distinguishing collisional and postcollisional ore-forming events difficult to impossible utilizing the currently available databases for Alaska. We combined the models in this analysis based on commonalities noted in chapters 2 and 3 .

\section{Deposit Group Characteristics}

The RIRG and orogenic systems have many similar characteristics. They form from similar $\mathrm{CO}_{2}-$ rich fluids, resulting in cryptic alteration dominated by chlorite-albite-carbonate assemblages and lesser sericite. They have strongly overlapping characteristics such as tungstenbismuth-tellurium (all soluble in high- $\mathrm{CO}_{2}$ fluids) geochemical associations and typically occur in structurally controlled quartz veins in collisional tectonic settings.

We emphasize that it is not presently believed, nor documented anywhere globally, that orogenic gold veins and RIRG systems are genetically related, and we do not intend to suggest here that these deposits are genetically related. However, their tectonic settings and geochemical signatures are similar, and our most robust datasets are geochemical.

\section{Mineral Resource Potential Estimation Method}

In this analysis for combined RIRG and orogenic gold deposits, all of our datasets were used. Scoring was weighted according to the ability of a dataset to discriminate these deposit types from the combined epithermal and porphyry deposit types. Consistent with the analysis of the combined porphyry-epithermal analysis in chapter 6 , only HUCs that yielded a medium- or high-prospectivity score in the undifferentiated lode gold model were scored for this combined RIRGorogenic analysis (plates 1,8). A major commonality in this combined deposit model is the presence of gold-bearing, polymetallic quartz veins and stockworks, which are broadly noted for some map units in the nsalith database of the digital geologic map of Alaska (Wilson and others, 2015), but not applicable at the HUC scale. The ARDF database provides strong indicators of specific types of deposits at discrete locations and is our best source for information on locating mineralized quartz veins. However, as reiterated in every model above, we limited the scoring of known deposits to avoid biasing results toward known districts and to address potential for undiscovered deposits. As noted in previous chapters, rock and sediment geochemistry are the most objective and efficient datasets for locating a concentration of target elements or minerals, and they again carry the dominant weighting in our scoring process. The HMC data carried less weight than rock and stream geochemistry owing to uneven distribution at the State scale. Although aeromagnetic data at the state scale are not applicable to the orogenic component of this combined analysis, we used filtered magnetic data tied to granitoid-bearing cells to address the RIRG component of this analysis, as described in chapter 3.

The total possible points for potential for the combined reduced intrusion-related and orogenic gold analysis is 94 points (table 12). If all datasets contribute to the total score, rock and stream sediment chemistry can carry as much as 59 percent of that score, HMC data as much as 14 percent, lithology as much as 19 percent, ARDF records as much as 5 percent, and the magnetic survey dataset as much as 3 percent of the potential score for a HUC. Only the total score, statistically binned by the Jenks (1967) method, was used to determine High, Medium, or Low potential. The points and percentages that each dataset contributed to the total score for each HUC can be queried in ArcGIS and are tabulated in Karl and others (2021). 


\section{Lithology}

The combined RIRG and orogenic gold deposit group model incorporates the favorable rock types from the digital map of Alaska nsalith database for both deposit types as described in chapters 2 and 3 . These include metavolcanic or metasedimentary schist, carbonaceous rocks, felsic and intermediate plutonic rocks, and lamprophyre (appendix 3). All rock types were given an equal weight of three points, additive, for a maximum possible score of 18 points (table 12). Application of this database contributed one point to the certainty score for a HUC (table 13).

\section{Alaska Resource Data File}

Most relevant ARDF keywords (appendix 2) for the RIRG and orogenic deposit grouping were combined from the orogenic and intrusion-related list; however, terms specifically related to porphyry systems were omitted for this analysis. Both intrusionrelated deposit types were not well recognized until after the Cox and Singer (1986) models were published; therefore, the only deposit model numbers assigned weight in the ARDF are those potentially related to RIRG and orogenic deposits: tungsten skarns that lack veins (model 14a) and those that contain veins (model $14 \mathrm{~b})$ sometimes associated with RIRG systems, and model 36a, gold veins in metamorphic rocks. Negative weights $(-1$ to -2$)$ were assigned to terms such as hematitic and ultramafic, which are generally not associated with these reduced gold systems. In contrast, ilmenite was given high weight, because it is associated with reduced intrusive phases. Some alteration terms like potassic, which are important in RIRG deposits, are nevertheless ubiquitous and were assigned low weight. For the RIRG-orogenic systems group, the Geologic Description field in ARDF was also queried because it contains keywords somewhat specific to this group, including metasediments, graphitic, sheeted, and quartz veins. The term "gold" (or other variations of gold) was only given high weight in the deposit model, ore minerals, and alteration fields, in order to eliminate overscoring resulting from numerous mentions in records that contain extensive detailed descriptions in other fields. The ARDF scoring bins are one point for keyword totals of $0-16$, three points for the range of 17-36, and five points for totals $>36$ (table 12). Application of this database contributed one point to the certainty score for a HUC (table 13).

\section{Rock and Sediment Geochemical Data}

As with the combined epithermal and gold-bearing porphyry model, in the combined reduced intrusion-related and orogenic model, scoring of gold and silver from rock geochemical data in the AGDB3 was removed from the analysis to minimize deposit model overlaps. Rock geochemical data were queried for the pathfinder suite of elements common among orogenic and RIRG systems, which includes $\mathrm{As}, \mathrm{W}, \mathrm{Bi}, \mathrm{Te}, \mathrm{Sb}$, and little to no $\mathrm{Cu}, \mathrm{Mo}$, or $\mathrm{Sn}$. Copper and molybdenum were fixed at less than 3.5 times background to avoid encompassing porphyry copper \pm molybdenum systems. Exclusion of tin in the analysis was an attempt to limit tungsten-tin skarns and porphyry tin-tungsten systems such as Kougarok on the northwestern Seward Peninsula (fig. 1), which occur throughout the State. The AGDB3 does not contain the appropriate geochemical data to determine the oxidation state of intrusions, so a reliance on the geochemical suite of elements commonly associated with these systems is necessary. The total possible score a sample in a HUC could receive for rock geochemistry is 28 points (table 12 ). Application of this dataset contributed one point to the certainty score for a HUC (table 13).

Similar to the utilization of rock geochemistry in this analysis, the presence of gold and silver in sediments was not used in the total sediment geochemical dataset score. Instead, pathfinder elements such as $\mathrm{As}, \mathrm{W}, \mathrm{Bi}$, and Te are emphasized for this model. Relative enrichments above background are scored such that more anomalous samples received a higher score than those near background. In contrast, copper, molybdenum, and tin are used in combination with pathfinder elements in order to help discriminate porphyry-related systems. Scoring is additive as outlined in (table 12), and a total possible stream sediment sample score for a HUC is 27 points. Application of this dataset contributed one point to the certainty score for a HUC (table 13).

\section{Heavy Mineral Concentrate Data}

Geochemical data are available for some of the HMC samples. These data were queried for the same pathfinder suite evaluated in the rock and sediment data: $\mathrm{As}, \mathrm{Bi}, \mathrm{Sb}$, and Te. If the geochemical values were $>$ background (appendix 1), a score of one point was awarded to a HUC. If a sample contained both tungsten and bismuth above background, a score of two points was awarded to a HUC (table 12). Points for $\mathrm{HMC}$ geochemical data are additive, yielding a maximum possible score of three points. Application of this dataset contributed one point to the certainty score of a HUC (table 13).

Heavy mineral concentrate data were used similarly to their application in the orogenic and RIRG models. Tungsten minerals are commonly refractory and present in both orogenic and RIRG systems. HMC data were searched for tungsten-bearing minerals, such as scheelite and wolframite, and given one point for potential if present in a HUC (table 12). Minerals more commonly associated with gold deposits, such as arsenopyrite, bismuthinite, and stibnite were given two points if present (table 13). Points for HMC mineralogical data are additive, yielding a maximum possible score of 11 points (table 12). Application of this dataset contributed one point to the certainty score of a HUC (table 13).

\section{Aerial Magnetic Survey Data}

Aerial magnetic survey data were used at the state scale as discussed in the Data Types and Analytical Process section for this combined RIRG and orogenic analysis. Aeromagnetic data are comprehensive statewide, but incapable of identifying quartz vein networks in the wide variety of host rocks in which they occur in this combined model. Acknowledging this limitation, 
the association with reduced intrusive rocks justifies application of the aeromagnetic dataset. As described in previous chapters, we filtered the aeromagnetic data to more precisely locate aeromagnetic anomalies and enhance contrast between highly magnetic and poorly magnetic rocks (Anderson and others, 2017) and we scored only granitoid-bearing cells in HUCs as described for intrusion-related deposits in chapter 4. Reduced intrusionrelated, ilmenite-series systems tend to have little or no magnetic signature in contrast to magnetite-series intrusions typical of porphyry systems (Ishihara, 1977, 1981; Hart and others, 2004a). Accordingly, HUCs containing cells that have negative magnetic values utilizing the filtered aeromagnetic data were awarded three points for potential to contain RIRG deposits (table 12). Application of this dataset for HUCs that contain granitoid rocks contributed one point to the certainty score of a HUC (table 13).

\section{Results and Discussion}

The combined RIR-orogenic model (plate 8) is generally in good agreement with the locations of known orogenic (plate 3) and RIRG (plate 4) systems but locally shows different proportions of high prospectivity relative to mediumprospectivity HUCs. Areas that show higher prospectivity for the combined model relative to the individual models include the Kokrines Hills belt and Yukon-Tanana uplands. Areas that show less prospectivity for the combined model than the individual models include the Brooks Range, Kuskokwim Mountains, central and eastern Alaska Range, Alaska Peninsula, Talkeetna Mountains, south central Alaska, and southeastern Alaska (fig. 1). Areas that have spotty highlights utilizing this model include the northern Seward Peninsula, Selawik-Zane Hills belt, southern Brooks Range, Alaska Peninsula, and parts of southeastern Alaska (fig. 1). In comparison with the combined epithermal-gold-bearing porphyry model (plate 7), the areas that show lower prospectivity for the combined RIRG-orogenic model show higher prospectivity on plate 8 , and areas that show higher prospectivity on plate 8 show lower prospectivity on plate 7. These complementary distributions suggest some success in our attempt to narrow parameters and increase discrimination between the gold ore-forming environments.

\section{Areas that have Known Prospectivity for Reduced-Intrusion-Related and Orogenic Gold Deposits}

The combined RIRG-orogenic gold prospectivity analysis consistently highlighted areas known to have orogenic gold deposits, such as the Seward Peninsula, the southern Brooks Range, and south- central and southeastern Alaska. Interestingly the combined model (plate 8) shows slightly less regional prospectivity than the orogenic model (plate 3 ) in south central and southeastern Alaska; however, areas that contain known deposits are coincident with red, high-prospectivity HUCs.

Areas known to contain RIRG deposits, especially the Yukon-Tanana uplands, show expanded high prospectivity in the combined model (plate 8) relative to the RIRG model (plate 4). Areas that are considered enigmatic with respect to gold ore-forming systems, such as the Kuskokwim Mountains and the western, central, and eastern Alaska Range, as discussed in previous chapters, have a smaller high prospectivity footprint in the combined model (plate 8) than the RIRG model (plate 4). In contrast, these enigmatic areas retain high prospectivity in the combined gold-bearing, porphyry-epithermal gold model (plate 7).

\section{Areas that have Newly Recognized Prospectivity for Reduced-Intrusion-Related and Orogenic Gold Deposits}

The combined reduced-intrusion-related and orogenic gold prospectivity analysis highlighted a few areas not known to contain these deposit types. The area that stands out in this respect is the Kokrines Hills belt (fig. 1) that is underlain by the Ruby batholith. The Ruby batholith includes a mix of alkaline to peraluminous granitic rocks (Arth and others, 1989a), hosted by tectonically thickened, metamorphosed continental margin rocks. These host rocks were regionally metamorphosed to blueschist and greenschist grades in a Mesozoic orogenic event similar to the metamorphic rocks on the Seward Peninsula and southern Brooks Range, but their stratigraphic affinities may be closer to rocks in the Yukon-Tanana uplands (Roeske and others, 1995), which indicates an overlap in geologic environments through time. The late Early Cretaceous granitic rocks in the Ruby batholith are slightly older than the middle Cretaceous plutons such as Fort Knox and Pogo that are associated with RIRG deposits in the Yukon-Tanana uplands. Although the area underlain by the Ruby batholith has mainly been prospected for tin and rare earth elements, the geologic setting is highly favorable for both reduced-intrusion-related and orogenic gold deposits.

The Selawik-Zane Hills belt (fig. 1) also shows increased prospectivity in the combined model (plate 8 ) relative to individual models (plates 3,4 ) and relative to the combined gold-bearing, porphyry-epithermal gold model (plate 7). This belt is underlain by middle to Late Cretaceous alkaline plutons (Arth and others, 1989b) that intrude arc rocks that structurally overlie tectonically thickened continental crust of the southern Brooks Range, which is a geologically favorable setting for both orogenic and RIRG gold deposits.

\section{Conclusions}

Distinguishing orogenic from RIRG systems is difficult owing to similarities in the geochemistry of ore-forming fluids that results in overlapping pathfinder fingerprints. The combined orogenic-RIRG model (plate 8) strongly correlates with regions of known orogenic and RIRG mineral occurrences. The model shows medium- to high-prospectivity HUCs extending outward from known mineral occurrences and identifies several underexplored areas of prospectivity, such as the Selawik-Zane Hills and the Kokrines Hills belts. 


\section{Chapter 8. Discussion of Discrimination of Lode Gold Deposit Types Using Model Combinations Based on Ore- forming Environments}

The results of our GIS analyses show that discriminating potential for the occurrence of individual lode gold deposit types is difficult when relying mostly on geochemical datasets. Our exercise of combining lode gold deposit types with respect to geologic ore-forming environments achieved some success in increasing the discrimination between the relatively oxidized and the relatively reduced hydrothermal systems (plates 7, 8) based on the lithologic and geochemical differences in these contrasting ore-forming environments. To evaluate the effectiveness of this strategy, we applied the overlap test described in chapter 5 to the two combined-model analyses.

\section{Method to Evaluate Deposit Model Group Overlap}

Overlap between the orogenic-RIRG and porphyryepithermal deposit groups was determined using the same procedures described in chapter 5 but modified for two deposit groups using the following equation:

$$
O_{i}=\frac{\left(t_{\text {epithermal-porphyy-norm }}^{i}+t_{\text {orogenic-RIRG }}^{i}\right)}{h_{\max }} \times 100
$$

where

$t^{i}$ is the total score for a given model for HUC $I$; and $h_{\max }$ is the total score of the highest-scoring HUC in all datasets.

To ensure the datasets used a common scale, total score values for the epithermal-porphyry deposit group were normalized to the highest actual total score of the orogenic-RIRG deposit group. This algorithm results in a possible range of 0 to 200 percent mineral potential overlap for the two deposits. Using this scale, a HUC that receives the highest actual score for both models would have 200 percent overlap between the deposit groups. Likewise, if both models score half of the highest score, the overlap is only 100 percent (in other words, medium potential for both groups). Overlap values between 100 and 200 percent could result from any combination of high- and medium-potential scores for both groups. Overlap values less than 100 percent indicate that one or both deposits scored low potential.

\section{Results and Discussion}

The results of this comparison (plate 9) indicate significantly less overlap (fewer dark purple HUCs) than is seen between the individual gold deposit models shown on plate 6. The areas that continue to show the most overlap for all deposit types include the Seward Peninsula, Kokrines Hills belt, western and eastern Alaska Range, and Yukon-Tanana uplands. Local documentation of the occurrence of multiple deposit types in these regions indicates the overlap in the models is capturing superposition of contrasting geologic environments. For example, the Yukon-Tanana uplands are characterized by middle Cretaceous RIRG and (or) orogenic gold systems (Fort Knox, Pogo) and Late Cretaceous-Paleocene porphyry systems (Taurus, Mosquito, Bluff). Stratigraphic ties to the western Yukon Territory that hosts Jurassic orogenic systems (for example, White Gold, Coffee) indicates possible overlap of multiple ore-forming environments (Kreiner and others, 2019). The important implication for this area of poor exposure is that strong potential for concentration of gold in sequential ore-forming settings merits further investigation. The Seward Peninsula exhibits strong indications of contrasting and superimposed styles of mineralization from Early Cretaceous orogenic gold veins to middle Cretaceous alkaline and Late Cretaceous porphyry systems (Miller and others, 2015; Karl and others, 2018). The western Alaska Range also contains systems that exhibit characteristics of contrasting oreforming environments, with juxtaposition of three ore system types (Graham and others, 2013): (1) the gold-bearing copper porphyry systems (Pebble, Copper Joe), (2) potential epithermal vein systems (Terra), and (3) enigmatic intrusion-related gold-rich, copper-poor RIRG systems (Estelle). Thus, much of the overlap exhibited by the ore-forming environment models is geologically predicted in these regions.

Less overlap between individual deposit types and the combined models is noticeable in the Kuskokwim and Chugach Mountains (plates 6, 9). The Kuskokwim Mountains contain examples of epithermal-style systems and possible hot spring environments, whereas the Chugach Mountains are known for orogenic systems like Crow Creek. This exercise demonstrates that we were able to increase precision for prospectivity for the two different lode gold, ore-forming processes, yet there is still considerable overlap, some of which is geologically expected and some is attributed to overlapping parameters and the limits and coarseness of our databases.

\section{Summary and Conclusions}

In summary, our geospatial analysis of prospectivity for undifferentiated and specific lode gold deposit types in Alaska applied publicly available geologic data to drainage basins at a regional scale. The parameters used in these prospectivity analyses include, but are not limited to (1) host and source rock types commonly found in prospective geologic environments; (2) favorable sediment and rock geochemistry characterized by anomalous values for gold, primary pathfinder suites that contain $\mathrm{Ag}, \mathrm{As}, \mathrm{Bi}, \mathrm{Sb}, \mathrm{Te}$, and (or) W, and secondary pathfinder suites that contain $\mathrm{Cu}, \mathrm{Mo}, \mathrm{Pb}$, and (or) $\mathrm{Zn}$; (3) HUCs that contain ARDF occurrences scored for keywords relevant to each lode gold deposit type; and (4) magnetic characteristics of intrusive rocks associated with gold deposits, summarized in table 14. We attempted to tailor data parameters to avoid bias and improve the precision of results. 
We weighted parameters according to the discriminating ability of the data type and the evenness of coverage of the data type statewide. The geochemical datasets have the best statewide spatial coverage, which minimizes geospatial bias, and gold and pathfinder trace elements are fairly reliable indicators of geologically favorable environments for gold mineralization. Systematic sediment sampling programs in Alaska minimize bias toward known areas of occurrences and allow recognition of potential for occurrences in areas that are covered or are not currently known to have gold potential. Although the geochemical datasets are plagued by high minimum detection limits and analytical techniques that may not be optimal for elements of particular interest, they are the strongest datasets available for all prospectivity models for lode gold. Our heavy reliance on geochemistry indicates that although Carlin-type deposits were not addressed in our analyses, if present their gold-bearing chemistry and mineralogy would include them in the undifferentiated/undivided model.

Other datasets have good statewide coverage and can discriminate some lode gold deposit types better than others. In the case of the lithologic dataset, hypabyssal rocks have a discrete association with epithermal deposits relative to other gold deposit types and are easy to extract at the HUC level from the digital map of Alaska. In contrast, a wide variety of metamorphic and igneous rock types can host gold deposits, but there is no consistent correlation of gold deposits with these rock types. The strongest lithologic correlation for gold is quartz veins, which are ubiquitous but not always gold bearing, and they are not map units and thus not applicable to discrete HUCs using the lithologic database. In the case of aeromagnetic data, the coarseness of the dataset does not allow the resolution required to effectively evaluate magnetic signatures at appropriate scales for hydrothermal systems and has limited applicability at the State scale because both magnetic and nonmagnetic rocks may host gold deposits. However, aeromagnetic data may be very helpful at local or district scales.

Still other datasets have a strong ability to discriminate gold deposit types but have sparse or spotty coverage across the State, which could bias analysis toward areas that have data over those that do not. The HMC dataset has important data but inhomogeneous coverage in Alaska based on limited and poorly distributed sample collection. The ARDF has some of the most specific data for discrimination of gold deposit type but can bias geospatial analyses toward known mineral occurrences at the expense of areas that may contain unknown, concealed occurrences.

Application of all datasets provided independent support to the score of a HUC. Although our scoring strategies were heavily weighted toward geochemistry, the other datasets played an important role in independently confirming the high prospectivity of HUCs and contributing to certainty scores. The ultimate result of our efforts to improve the objectivity and precision of prospectivity analyses for gold in Alaska is successful identification of areas of known occurrences, expanded prospectivity around areas of known occurrences, and identification of a few new areas that may have potential for gold deposits in Alaska.
Primary observations regarding the analytical process are listed below.

1. Data-driven geospatial analysis of potential for lode gold deposits in Alaska, although limited by the size and evenness of coverage of available datasets, objectively indicates prospectivity in areas where exposure is good as well as in areas where exposure is poor. It highlights prospectivity for several large regions in the State, including areas known to be mineralized.

2. Overlap in model-defining parameters, geologic settings, and ore-forming processes for different lode gold deposit types inherently leads to overlap in apparent prospectivity assessments for different subtypes of lode gold deposits across Alaska. The overlap provides strong confidence in gold prospectivity in many parts of the State and supports an undifferentiated model for reliable application in land-use decisions.

3. Overlap in prospectivity for various lode gold deposit types and combinations of deposit types should be evaluated in terms of data distribution and quality. However, in some cases, overlap in deposit prospectivity shown by our analyses may reflect real overlap of different hydrothermal systems in space and (or) time.

4. Medium- to high-prospectivity determinations in areas that surround known deposits in Alaska likely reflect district-scale metallogenesis and indicate strong potential for expansion of these districts. Detailed investigations and exploration in these areas may identify new deposits and help to improve the balance in volume between gold produced in placer districts and identified lode sources for the placer deposits statewide.

5. The results of our GIS analyses highlight several areas not known to contain lode gold deposits. These areas may warrant additional investigation.

6. The overlap in our analyses for the traditional classifications for lode gold inspired an exercise in alternative groupings of deposit types focused on oreforming environments and associated geochemistry that might be more easily discriminated if additional data become available. This exercise succeeded in narrowing the amount of overlap between the main deposit types (plate 9) but could not eliminate it. Much of the overlap encapsulated in the models occurs in regions known to contain mineral occurrences characteristic of both models, suggesting a superposition of hydrothermal systems in space and time.

7. Application of the datasets in our GIS analyses highlights the limitations of available geologic data for Alaska. There is an inevitable bias toward areas that have data over areas that lack data. Identification of shortcomings of the datasets, particularly uneven data distribution, helps to identify needs for future data 
collection and investigation. Improved statewide data coverage could lead to discovery of gold deposits in areas that lacked sufficient data in the current model iteration. In addition, our analyses have identified desirable types of data, such as alteration, that would facilitate analyses, but which are buried in or missing from available datasets.

Primary results of our analyses of lode gold prospectivity in Alaska are listed below.

1. The analysis for undivided lode gold deposits (plate 1), in comparison with known occurrences (plate 2), shows that there are large areas in the State that have medium to high prospectivity, with variable levels of confidence, that may be underexplored for lode gold. Examples include the western Brooks Range, Selawik-Zane Hills and Kokrines Hills belts, Yukon-Tanana uplands, southwestern Alaska, and Alaska Peninsula.

2. Prospectivity analysis for orogenic gold deposits highlights regions that have known orogenic deposits as well as other areas that have favorable geologic settings for orogenic deposits, including the Seward Peninsula, the Brooks Range, and south-central and southeastern Alaska (plate 3). One area that has favorable geology but is not evaluated owing to lack of data is Kodiak Island.

3. Prospectivity analysis for reduced intrusion-related gold deposits highlights areas of known RIRG occurrences and shows similar regional distribution to that of orogenic deposits (plate 3 ) but shows slightly more abundant high prospectivity at higher confidence levels (plate 4). Areas highlighted for RIRG that may be underexplored include the Selawik-Zane Hills and Kokrines Hills belts, the Yukon-Tanana uplands (especially in the area around Tetlin), and southwestern Alaska.

4. The analysis for epithermal gold deposits shows widespread high prospectivity and significant overlap with all deposit types (plates 1-5). Known deposits of this type are not widely recognized in the State except on the Alaska Peninsula-Aleutian Islands but may be under evaluated because young epithermal systems overlap more regionally dominant geologic settings. Areas that may have spatially overlapping settings, such as coeval intrusive, hypabyssal, and volcanic rocks, include the Kuskokwim Mountains, the Selawik-Zane Hills, the Kokrines Hills belt, and the Yukon-Tanana uplands.
Additional areas that may have such overlap in geologic setting, and also contain mercury and pathfinder elements typical of epithermal deposits, include the western Alaska Range, Yukon-Tanana uplands, Wrangell Mountains, and southeastern Alaska. The areas highlighted for this deposit type (plate 5) are likely underexplored owing to limited availability of a key parameter - alteration datastatewide. Investigations for other lode gold deposit types in the State should be undertaken with an eye to evidence for epithermal deposits.

5. Our analyses highlight areas in Alaska most in need of additional studies to provide pertinent geologic and geochemical data. These areas have medium to high potential despite medium to low certainty owing to limited data and could garner much higher scores for potential with contributions from additional data types. Examples include the Hogatza igneous belt in the Selawik-Zane Hills area south of the Kobuk Fault, southwestern Alaska, and the Yukon-Tanana uplands. Other areas that are light green in color on all plates ostensibly have low resource potential, but this is based on very little data and could be misleading. Finally, large areas of the State are colored gray and remain unevaluated owing to lack of data but lie within belts of favorable geology. These include Kodiak Island and large areas in southwestern Alaska that are near significant known deposits in the Kuskokwim Mountains (plate 2) and may have a similar geologic setting and prospectivity.

In conclusion, our analyses for specific types of lode gold deposits in Alaska show that with available data, discriminating gold deposit types for targeted exploration at a regional scale is extremely difficult without grouping them according to oreforming environments. The complicated geologic history of Alaska, characterized by incremental juxtaposition of a mix of continental and oceanic terranes to the margin of the North American craton over time and continuing active subduction, arc volcanism, and oblique translation on continental-scale faults, inevitably resulted in overlapping geologic settings. In many applications, the debate over deposit classification will be less important than looking for evidence of overlap of hydrothermal systems in space and time that might impact the transport and concentration of gold. Distinguishing the types of hydrothermal systems more accurately and precisely with more detailed data at the district and deposit scales. At the regional scale, however, the undivided lode gold model provides the most practical and reliable approach. 


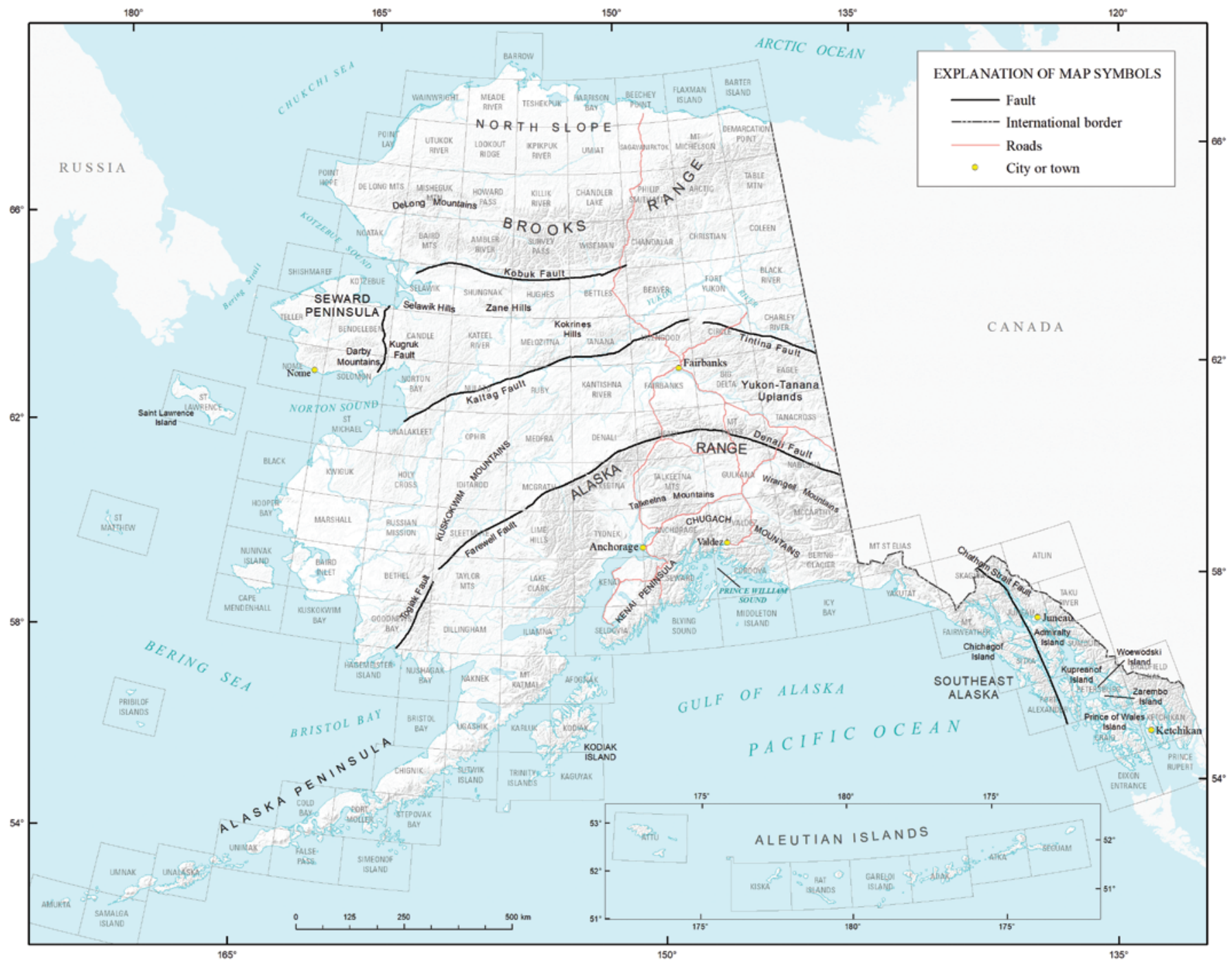

Figure 1. Physiographic map of Alaska showing place names and major faults, which provide a reference frame for locating regional trends in prospectivity.

\section{Data Resources}

Airborne Geophysical Surveys of the Mineral Resources Online Spatial Database - https://mrdata.usgs.gov/\#geophysics

Alaska Resource Data File (ARDF; U.S. Geological Survey, undated) - https://ardf.wr.usgs.gov/

Alaska Geochemical Database, Version 3.0 (AGDB3) - http:// pubs.usgs.gov/ds/759/

Mineral Resources Online Spatial Data - https://mrdata.usgs. gov/airborne/map.html
National Hydrography dataset - http://nhd.usgs.gov/

National Uranium Resource Evaluation (NURE) Hydrogeochemical and Stream Sediment Reconnaissance data http://pubs.usgs.gov/of/1997/ofr-97-0492/

Alaska Division of Geological \& Geophysical Surveys Alaska Geochemistry database - http://doi.org/10.14509/geochem

Alaska Aerial Magnetic Survey (Saltus and Simmons, 1997) https://pubs.usgs.gov/of/1997/ofr-97-0520/; https://mrdata. usgs.gov/general/map-ak.html

Geologic Map of Alaska (Wilson and others, 2015) - http:// dx.doi.org/10.3133/sim 3340 


\section{References Cited}

Allan, M.M., Mortensen, J.K., Hart, C.J., Bailey, L.A., Sanchez, M.G., Ciolkiewicz, W., McKenzie, G.G., and Creaser, R.A., 2013, Magmatic and metallogenic framework of west-central Yukon and eastern Alaska: Society of Economic Geologists Special Publication 17, p. 111-168.

Anderson, E.D., Monecke, T., Hitzman, M.W., Zhou, W., and Bedrosian, P.A., 2017, Mineral potential mapping in an accreted island-arc setting using aeromagnetic data-An example from southwest Alaska: Economic Geology, v. 112, p. 375-396.

Arbogast, B.F., 1990, Quality assurance manual for the Branch of Geochemistry, U.S. Geological Survey: U.S. Geological Survey Open-File Report 90-668, 184 p.

Arbogast, B.F., ed., 1996, Analytical methods manual for the Mineral Resource Surveys Program, U.S. Geological Survey: U.S. Geological Survey Open-File Report 96-525, 248 p.

Arribas, A., Jr., Hedenquist, J.W., Itaya, T., Okada, T., Concepcion, R.A., and Garcia, J.S., 1995, Contemporaneous formation of adjacent porphyry and epithermal $\mathrm{Cu}-\mathrm{Au}$ deposits over $300 \mathrm{ka}$ in northern Luzon, Philippines: Geology, v. 23, p. 337-340.

Arth, J.G., Criss. R.E., Zmuda, C.C., Foley, N.K., Patton, W.W., Jr., and Miller, T.P., 1989a, Remarkable isotopic and trace element trends in potassic through sodic Cretaceous plutons of the Yukon-Koyukuk basin, Alaska, and the nature of lithosphere beneath the Koyukuk terrane: Journal of Geophysical Research, v. 94, no. B11, p. 15957-15968.

Arth, J.G., Zmuda, C.C., Foley, N.K., Criss, R.E., Patton, W.W., Jr., and Miller, T.P., 1989b, Isotopic and trace element variations in the Ruby batholith, Alaska, and the nature of the deep crust beneath the Ruby and Angayucham terranes: Journal of Geophysical Research, v. 94, no. B11, p. 15941-15955.

Athey, J.E., Harbo, L.A., Lasley, P.S., and Freeman, L.K., 2013, Alaska's mineral industry 2012: Alaska Division of Geological \& Geophysical Surveys Special Report 68, 61 p.

Athey, J.E., and Werdon, M.B., 2017, Alaska's mineral industry 2016: Alaska Division of Geological \& Geophysical Surveys Special Report 72, 65 p. [Also available at http://doi. org/10.14509/29748.]

Athey, J.E., and Werdon, M.B., 2018, Alaska's mineral industry 2017: Alaska Division of Geological \& Geophysical Surveys Special Report 73, 92 p. [Also available at http://doi. org/10.14509/30075.]
Bakke, A., Morrell, B., Odden, J., Bergstrom, T., and Woodman, J., 2000, Kinross Gold USA's activities in the Fairbanks Mining District, K2K, in Tucker, T.L., and Smith, M.T., eds., The Tintina gold belt - Concepts, exploration, and discoveries: British Columbia and Yukon Chamber of Mines, Special Volume 2, p. 89-98.

Barker, J.C., Murray, R.B., Keener, J.O., and Martin, P.L., 2009, Evaluation of the Chandalar mining property: Unpublished report for Goldrich Mining Company, 165 p. [Also available at https://www.goldrichmining.com/media/downloads/technical_reports/Chandalar_tech_rept_4_15_09.pdf.]

Barton, P.B., Bethke, P.M., and Roedder, E., 1977, Environment of ore deposition in the Creede mining district, San Juan Mountains, Colorado; Part III. Progress toward of interpretation of the chemistry of the ore-forming fluid of the $\mathrm{OH}$ vein: Economic Geology, v. 72, p. 1-24.

Bissig, T., Clark, A.H., Lee, J.K.W., and Hodgson, C.J., 2002, Miocene landscape evolution and geomorphic controls on epithermal processes in El Indio-Pascua Au-Ag-Cu belt, Chile and Argentina: Economic Geology, v. 97, p. 971-996.

Bittenbender, P., Still, J.C., Maas, K., and McDonald, M., Jr., 1999, Mineral resources of the Chichagof and Baranof Islands area, southeast Alaska: Bureau of Land Management, BLMAlaska Technical Report 19, 222 p.

Blakely, R.J., 1995, Potential theory in gravity and magnetic applications: Cambridge, U.K., Cambridge University Press, $441 \mathrm{p}$.

Bleick, H.A., Till, A.B., Bradley, D.C., O’Sullivan, P., Wooden, J.L., Bradley, D.B., Taylor, T.A., Friedman, S.B., and Hults, C.P., 2012, Early Tertiary exhumation of the flank of a forearc basin, southwest Talkeetna Mountains, Alaska: U.S. Geological Survey Open-File Report 2012-1232, 1 sheet.

Bonham, H.F., Jr., 1986, Models for volcanic-hosted epithermal precious metals deposits-A review: Volcanism, Hydrothermal Systems, and Related Mineralisation, 5th International Volcanological Congress, University of Auckland, Auckland, New Zealand, Proceedings, p. 13-17.

Bonham, H.F., Jr., 1988, Models for volcanic-hosted precious metal deposits - A review, in Schafer, R.W., Cooper, J.J., and Vikre, P.G., eds., Bulk precious metal deposits of the western United States: Reno, Geological Society of Nevada, p. 259-271.

Bouley, B.A., St. George, P., and Wetherbee, P.K., 1995, Geology and discovery at Pebble Copper, a copper-gold porphyry system in southwest Alaska: Canadian Institute of Mining, Metallurgy, and Petroleum, Special Volume 46, p. 422-435. 
Bradley, D.C., Kusky, T.M., Haeussler, P.J., Karl, S.M., and Donley, D.T., 1999, Geologic map of the Seldovia quadrangle, south-central Alaska: U.S. Geological Survey Open-File Report 99-18, scale 1:250,000.

Brathwaite, R.L., and Faure, K., 2002, The Waihi epithermal gold-silver-base metal sulfide quartz vein system, New Zealand-Temperature and salinity controls on electrum and sulfide deposition: Economic Geology, v. 97, p. 269-290.

Brew, D.A., and Ford, A.B., 1985, Preliminary reconnaissance geologic map of the Juneau, Taku River, Atlin, and part of the Skagway quadrangles, southeastern Alaska: U.S. Geological Survey Open-File Report 85-395, scale 1:250,000.

Bryant, D.G., and Metz, H.E., 1966, Geology and ore deposits of the Warren mining district, in Titley, S.R., and Hicks, C.L., eds., Geology of the porphyry copper deposits, southwestern North America: Tucson, University of Arizona Press, p. 189-203.

Buchanan, L.J., 1981, Precious metal deposits associated with volcanic environments in the Southwest: Arizona Geological Society Digest, v. 14, p. 237-262.

Bull, K.F., 1988, Genesis of the Golden Horn and related mineralization in the Flat Creek area, Alaska: Fairbanks, University of Alaska, M.S. thesis, $300 \mathrm{p}$.

Bundtzen, T.K., and Laird, G.M., 1983, Geologic map of the Iditarod D-1 quadrangle, Alaska: Alaska Division of Geological \& Geophysical Surveys Professional Report 78, scale $1: 63,360$.

Bundtzen, T.K., and Laird, G.M., 2007, Geologic map of the Chandalar mining district, Brooks Range, northern Alaska, 2007: Unpublished map prepared for Little Squaw Gold Mining Company, 1 sheet, scale 1:20,000. [Also available at https://www.goldrichmining.com/media/downloads/technical_reports/regional_chandalar_geo_map_final_07.pdf.]

Bundtzen, T.K., Miller, M.L., Laird, G.M., and Bull, K.F., 1992, Geology and mineral resources of Iditarod mining district, Iditarod B-4 and eastern B-5 quadrangles, southwestern Alaska: Alaska Division of Geological \& Geophysical Surveys Professional Report 97, 46 p., 2 sheets, scale 1:63,360.

Burleigh, R.E., 1987, A stable isotope, fluid inclusion and ore petrographic study of gold-quartz veins in the Willow Creek mining district, Alaska: Fairbanks, University of Alaska, M.S. thesis, $84 \mathrm{p}$.

Cady, W.M., Wallace, R.E., Hoare, J.M., and Webber, E.J., 1955, The central Kuskokwim region, Alaska: U.S. Geological Survey Professional Paper 268, 132 p.

Cathcart, S.H., 1922, Metalliferous lodes in southern Seward Peninsula: U.S. Geological Survey Bulletin 722-F, p. 163-261.
Chipp, E.R., 1972, Analyses of rock and stream sediment samples, Wild Lake area, Wiseman quadrangle, Arctic Alaska: Alaska Division of Geological Survey Geochemical Report 25, 1 sheet, scale 1:48,000. [Also available at http://doi. $\operatorname{org} / 10.14509 / 260$.]

Cline, J.S., Hofstra, A.H., Muntean, J.L., Tosdal, R.M., and Hickey, K.A., 2005, Carlin-type gold deposits in NevadaCritical geologic characteristics and viable metals, in Hedenquist, J.W., Thompson, J.F.H., Goldfarb, R.J., and Richards, J.P., eds., Economic Geology — One hundredth anniversary volume, 1905-2005: Society of Economic Geologists, p. 451-484.

Clode, C.H., Proffett, J.M., Jr., Mitchell, P.A., and Munajat, I., 1999, Relationships of intrusion, wallrock alteration, and mineralization in the Batu Hijau copper-gold porphyry deposit: PACRIM '99, Australasian Institute of Mining and Metallurgy Congress Proceedings, Bali, Indonesia, October 10-13, 1999, p. 485-498.

Collier, A.J., Hess, F.L., Smith, P.S., and Brooks, A.H., 1908, The gold placers of parts of Seward Peninsula, Alaska, including the Nome, Council, Kougarok, Port Clarence, and Goodhope precincts: U.S. Geological Survey Bulletin 328, 343 p.

Connard, G.G., Saltus, R.W., Hill, P.L., Carlson, L., and Milicevic, B., 1999, Alaska digital aeromagnetic database description: U.S. Geological Survey Open-File Report 99-503, 12 p.

Cox, D.P., and Singer, D.A., eds., 1986, Mineral deposit models: U.S. Geological Survey Bulletin 1693, 379 p.

Crowe, D.E., Milholland, M.A., and Brown, P.E., 1991, Precious and base metal mineralization associated with high-salinity fluids in the Mount Estelle pluton, south central Alaska: Economic Geology, v. 86, p. 1103-1109.

Decker, J.E., Bergman, S.C., Blodgett, R.B., Box, S.E., Bundtzen, T.K., Clough, J.G., Coonrad, W.L., Gilbert, W.G., Miller, M.L., Murphy. J.M., Robinson, M.S., and Wallace, W.K., 1994, Geology of southwestern Alaska, in Plafker, G., and Berg, H.C., eds., The geology of Alaska: Boulder, Colorado, Geological Society of America, The Geology of North America, v. G-1, p. 285-309.

DiMarchi, J.J., 1993, Geology, alteration, and mineralization of the Vinasale Mountain gold deposit, west-central Alaska, in Solie, D.N., and Tannian, F., eds., Short notes on Alaska Geology 1993: Professional Report PR 113, p. 17-30.

Dumoulin, J.A., Harris, A.G., and Repetski, J.E., 2014, Carbonate rocks of the Seward Peninsula Alaska-Their correlation and paleogeographic significance, in Dumoulin, J.A., and Till, A.B., eds., Reconstruction of a late Proterozoic to Devonian continental margin sequence, northern Alaska, its paleogeographic significance, and contained base-metal sulfide deposits: Geological Society of America Special Paper 506, p. 59-110. [Also available at https://doi.org/10.1130/2014.2506(03).] 
Einaudi, M.T., Hedenquist, J.W., and Inan, E., 2003, Sulfidation state of fluids in active and extinct hydrothermal systemsTransitions from porphyry to epithermal environments: Society of Economic Geologists Special Publication 10, p. 285-314.

Ford, A.B., Palmer, C.A., and Brew, D.A., 1996, Geochemistry of the andesitic Admiralty Island volcanics, an Oligocene rift-related basalt to rhyolite suite of southeastern Alaska, in Moore, T.E., and Dumoulin, J.A., Geologic studies in Alaska by the U.S. Geological Survey, 1994: U.S. Geological Survey Bulletin 2152, p. 177-204.

Fortescue, J.A.C., 1992, Landscape geochemistry-Retrospect and prospect-1990: Applied Geochemistry, v. 7, p. 1-53.

Frisken, J.G., 1992, Interpretation of reconnaissance geochemical data from the Port Moller, Stepovak Bay, and Simeonof Island quadrangles, Alaska Peninsula, Alaska: U.S. Geological Survey Bulletin 1968, scale 1:250,000, 47 p.

Gage, B.G., and Newberry, R.J., 2003, Ore mineralogy and mineral compositions from the Golden Zone mine, southcentral Alaska, in Clautice, K.H., and Davos. P.K., eds., Short notes on Alaska Geology 2003: Alaska Division of Geological \& Geophysical Surveys Professional Report 120, p. 21-33.

Garnett, R.H.T., and Bassett, N.C., 2005, Placer deposits, in Hedenquist, J.W., Thompson, J.F.H., Goldfarb, R.J., and Richards, J.P., eds., Economic Geology — One hundredth anniversary volume, 1905-2005: Society of Economic Geologists, p. 813-843.

Gehrels, G.E., and Saleeby, J.B., 1987, Geology of southern Prince of Wales Island, southeastern Alaska: Geological Society of America Bulletin, v.98, p.123-137.

Gilman, T., Feineman, M., and Fisher, D., 2009, The Chulitna terrane of south central Alaska - A rifted volcanic arc caught between the Wrangellia composite terrane and the Mesozoic margin of North America: Geological Society of America Bulletin, v. 121, no. 7-8, p. 979-991. [Also available at https://doi. org/10.1130/B26400.1.]

Goldfarb, R.J., Ayuso, R.A., Miller, M.L., Ebert, S.W., Marsh, E.E., Petsel, S.A., Miller, L.D., Bradley, D.C., Johnson, C., and McClelland, W.C., 2004, The Late Cretaceous Donlin Creek gold deposit, southwestern Alaska-Controls on epizonal ore formation: Economic Geology, v. 99, p. 643-671.

Goldfarb, R.J., Baker, T., Dube, B., Groves, D.I., Hart, C.J.R., and Patrice, G., 2005, Distribution, character, and genesis of gold deposits in metamorphic terranes, in Hedenquist, J.W., Thompson, J.F.H., Goldfarb, R.J., and Richards, J.P., eds., Economic Geology - One hundredth anniversary volume, 1905-2005: Society of Economic Geologists, p. 407-450.

Goldfarb, R.J., and Groves, D.I., 2015, Orogenic gold-Common or evolving fluid and metal sources through time: Lithos, v. 33, p. 2-26.
Goldfarb, R.J., Groves, D.I., and Gardoll, S., 2001, Orogenic gold and geologic time-A global synthesis: Ore Geology Reviews, v. 18, p. 1-75. [Also available at https://doi. org/10.1016/S0169-1368(01)00016-6.]

Goldfarb, R.J., Hofstra, A.H., and Simmons, S.F., 2016, Critical elements in Carlin, epithermal, and orogenic gold deposits: Reviews in Economic Geology, v. 18, p. 217-244.

Goldfarb, R.J., Leach, D.L., Pickthorn, W.J., and Paterson, C.J., 1988, Origin of lode-gold deposits of the Juneau gold belt, southeastern Alaska: Geology, v. 16, p. 440-443.

Goldfarb, R.J., Miller, L.D., Leach, D.L., and Snee, L.W., 1997, Gold deposits in metamorphic rocks of Alaska: Economic Geology Monographs, v. 9, p. 151-190.

Goldfarb, R.J., Newberry, R.J., Pickthorn, W.J., and Gent, C.A., 1991, Oxygen, hydrogen, and sulfur isotope studies in the Juneau gold belt, southeastern Alaska; constraints on the origin of hydrothermal fluids: Economic Geology, v. 86, p. 66-80.

Goudarzi, G.H., comp., 1984, Guide to preparation of mineral survey reports on public lands: U.S. Geological Survey OpenFile Report 84-0787, 41 p.

Graham, G.E., Goldfarb, R.J., Miller, M.L., Gibler, K., and Roberts, M., 2013, Tectonic evolution and Cretaceous gold metallogenesis of southwestern Alaska: Society of Economic Geologists Special Publication 17, p. 169-200.

Granitto, M., Bailey, E.A., Schmidt, J.M., Shew, N.B., Gamble, B.M., and Labay, K.A., 2011, Alaska Geochemical Database (AGDB) - Geochemical data for rock, sediment, soil, mineral, and concentrate sample media: U.S. Geological Survey Data Series 637, $31 \mathrm{p}$.

Granitto, M., Schmidt, J.M., Shew, N.B., Gamble, B.M., and Labay, K.A., 2013, Alaska Geochemical Database, version 2.0 (AGDB2) - Including "best value" data compilations for rock, sediment, soil, mineral, and concentrate sample media: U.S. Geological Survey Data Series 759, 20 p.

Granitto, M., Wang, B., Shew, N.B., Karl, S.M., Labay, K.A., Werdon, M.B., Seitz, S.S., and Hoppe, J.E., 2019, Alaska Geochemical Database version 3.0 (AGDB3)—-Including "best value" data compilations for rock, sediment, soil, mineral, and concentrate sample media: U.S. Geological Survey Data Series 1117, 33 p. [Also available at https://doi.org/10.3133/ds1117.]

Gray, J.E., Frost, T.P., Goldfarb, R.J., and Detra, D.E., 1990, Gold associated with cinnabar- and stibnite-bearing deposits and mineral occurrences in the Kuskokwim River region, southwestern Alaska: U.S. Geological Survey Bulletin 1950, p. D1-D6.

Gray, J.E., Gent, C.A., and Snee, L.W., 1997, Epithermal mercury-antimony and gold-bearing vein lodes of southwestern Alaska: Economic Geology Monographs, v. 9, p. 287-305. 
Groves, D.I., Goldfarb, R.J., and Santohs, M., 2016, The conjunction of factors that lead to formation of giant gold provinces and deposits in non-arc settings: Geoscience Frontiers, v. 7, p. 303-314. [Also available at http://dx.doi.org/10.1016/j. gsf.2015.07.001.]

Gustafson, L.B., and Hunt, J.P., 1975, Porphyry copper deposit at El Salvador, Chile: Economic Geology, v. 70, p. 857-912.

Haeussler, P.J., Bradley, D.C., Goldfarb, R.J., Snee, L.W., and Taylor, C., 1995, Link between ridge subduction and gold mineralization in southern Alaska: Geology, v. 23, no. 11, p. 995-998.

Haeussler, P.J., Karl, S.M., Mortensen, J.K., Layer, P., and Himmelberg, G., 1999, Permian and mid-Cretaceous deformation of the Alexander terrane on Admiralty and Kupreanof Islands, southeastern Alaska [abs.]: Geological Society of America Abstracts with Programs, v. 31, no. 6, p. A-60.

Hames, B., Roberts, M.R., and Hart, C., 2012, The Whistler porphyry $\mathrm{Au}-\mathrm{Cu}$ system - Geometry and paragenesis: Vancouver, BC; AMABC Mineral Exploration Roundup, January 22-24, 2012, poster.

Hanson, K., Seibel, G., Wortman, G., and Kozak, A., 2009, Donlin Creek gold project, Alaska, USA: NI43-101 Technical Report for Nova Gold Resources Inc., 222 p. [Also available at www.sedar.com.]

Harlan, S.S., Snee, L.W., Vielreicher, R.M., Goldfarb, R.G., Mortensen, J., and Bradley, D.C., 2003, Age and cooling history of gold deposits and host rocks in the Willow Creek mining district, Talkeetna Mountains, south central Alaska [abs.]: Geological Society of America Abstracts with programs, v. 35, no. 6, p. 235.

Hart, C.J.R., 2007, Reduced intrusion-related gold systems, in Goodfellow, W.D., ed., Mineral deposits of Canada-A synthesis of major deposit-types, district metallogeny, the evolution of geological provinces, and exploration methods: Geological Association of Canada, Mineral Deposits Division, Special Publication no. 5, p. 95-112.

Hart, C.J.R., and Goldfarb, R.J., 2005, Distinguishing intrusionrelated from orogenic gold systems: New Zealand Minerals Conference Proceedings, p. 125-133.

Hart, C.J.R., Goldfarb, R.J., Lewis, L.L., and Mair, J.L., 2004a, The northern Cordilleran mid-Cretaceous plutonic provinceIlmenite/magnetite-series granitoids and intrusion-related mineralization: Resource Geology, v. 54, no. 3, p. 253-280.

Hart, C.J.R., Mair, J.L., Goldfarb, R.J., and Groves, D.I., 2004b, Source and redox controls on metallogenic variations in intrusion-related ore systems, Tombstone-Tungsten belt, Yukon Territory, Canada: Transactions of the Royal Society of Edinburgh, Earth Sciences, v. 95, p. 339-356. [Also available at https://doi.org/10.1017/S0263593300001115.]
Hart, C., Mccoy, D.T., Goldfarb, R.J., Smith, M., Roberts, P., Hulstein, R., Bakke, A.A., and Bundtzen, T.K., 2002, Geology, exploration, and discovery in the Tintina gold province, Alaska and Yukon: Society of Economic Geologists Special Publication, Integrated Methods for Discovery, Global Exploration in the Twenty-First Century, p. 241-274.

Harvey, B., Meyers, S., and Klein, T., 1999, Yanacocha gold district, northern Peru: Pacific Rim Congress, Bali, Indonesia, Australasian Institute of Mining and Metallurgy Proceedings, p. 445-459.

Hawley, C.C., and Clark, A.L., 1974, Geology and mineral deposits of the upper Chulitna district, Alaska: U.S. Geological Survey Professional Paper 758-B, p. B1-B47, 2 plates, scale $1: 12,000$ and $1: 48,000$.

Hedderly-Smith, D.A., 1993, Report of the 1992 field seasonSealaska reconnaissance project: Sealaska Corp., 114 p., 11 plates.

Hedenquist, J.W., 1987, Mineralization associated with volcanicrelated hydrothermal systems in the circum-Pacific basin: Transactions of the Fourth Circum-Pacific Conference on Energy and Mineral Resources, Singapore, American Association of Petroleum Geologists, p. 513-524.

Hedenquist, J.W., Arribas, A.R., and Aoki, M., 2017, Zonation of sulfate and sulfide minerals and isotopic composition in the Far Southeast Porphyry and Lepanto Epithermal $\mathrm{Cu}-\mathrm{Au}$ deposits, Philippines: Resource Geology, v. 67, p. 174-196.

Hedenquist, J.W., Arribas, A., Jr., and Reynolds, T.J., 1998, Evolution of an intrusion-centered hydrothermal system - Far Southeast-Lepanto porphyry and epithermal $\mathrm{Cu}-\mathrm{Au}$ deposits, Philippines: Economic Geology, v. 93, p. 245-277.

Hedenquist, J.W., and Lowenstern, J.B., 1994, The role of magmas in the formation of hydrothermal ore deposits: Nature, $v$. 370, p. 519-527.

Heinrich, C.A., 2005, The physical and chemical evolution of low-salinity magmatic fluids at the porphyry to epithermal transition-A thermodynamic study: Mineralium Deposita, v. 39, p. 864-899.

Helsel, D.R., 2012, Statistics for censored environmental data using Minitab and R: New York, John Wiley and Sons, 344 p.

Hildreth, W., 1981, Gradients in silicic magma chambers-Implications for lithospheric magmatism: Journal of Geophysical Research, v. 86, p. 10153-10192.

Hoekzema, R.B., Fechner, S.A., and Kurtak, J.M., 1986, Evaluation of selected lode gold deposits in the Chugach National Forest, Alaska: U.S. Bureau of Mines Information Circular 9113, $62 \mathrm{p}$. 
Illig, P.E., 2015, Geology and origins of the Peak gold-coppersilver skarn deposit, Tok, Alaska: Fairbanks, University of Alaska, Department of Geosciences, M.S. thesis, 166 p.

Ishihara, S., 1977, The magnetite-series and ilmenite-series granitic rocks: Mining Geology, v. 27, p 293-305.

Ishihara, S., 1981, The granitoid series and mineralization: Economic Geology, 75th Anniversary Volume, p. 458-484.

Ishihara, S., 1998, Granitoid series and mineralization in the circum-Pacific Phanerozoic belts: Resource Geology, v. 8, p. 219-224.

Ishihara, S., and Terashima, S., 1989, Carbon contents of the magnetite-series and ilmenite-series granitoids in Japan: Geochemical Journal, v. 23, p. 25-36.

Jenks, G.F., 1967, The data model concept in statistical mapping: International Yearbook of Cartography, v. 7, no. 1, p.186-190.

Jensen, E.P., and Barton, M.D., 2000, Gold deposits related to alkaline magmatism: Reviews in Economic Geology, v. 13, p. 210-314.

Jia, Y., and Kerrich, R., 1999, Nitrogen isotope systematics of mesothermal lode gold deposits, metamorphic, granitic, meteoric water, or mantle origin?: Geology, v. 27, p. 1051-1054.

John, D.A., 1981, Miocene and early Pliocene epithermal goldsilver deposits of the northern Great Basin, western United States - Characteristics, distribution, and relations to magmatism: Economic Geology, v. 96, p. 1827-1853.

John, D.A., Garside, L.J., and Wallace, A.R., 1999, Magmatic and tectonic setting of late Cenozoic epithermal gold-silver deposits in northern Nevada, with an emphasis on the Pah Rah and Virginia Ranges and northern Nevada rift: Geological Society of Nevada Special Publication 29, p. 65-128.

Jones, J.V., III, Mauk, J.L., Labay, K.A., Shew, N.B., and Granitto, M., 2016, Placer and paleoplacer gold (Au) deposits, in Karl, S.M., Jones, J.V., III, and Hayes, T.S., eds., GIS-based identification of areas that have resource potential for critical minerals in six selected groups of deposit types in Alaska: U.S. Geological Survey Open-File Report 2016-1191, p. 28-30, 2 plates. [Also available at http://dx.doi.org/10.3133/ofr20161191.]

Kaplan, E.L., and Meier, P., 1958, Nonparametric estimation from incomplete observations: Journal of the American Statistical Association, v. 53, p. 457-481.

Karl, S.M., Drewes, E., Kreiner, D.C., Case, G.C., Box, S.E., Pongratz, A., and Allard, A., 2018, Petrology and REE potential of mid-Cretaceous high-K plutonic rocks in the Darby Mountains, Seward Peninsula, Alaska [abs.]: Alaska Geological Society Technical Conference Program with Abstracts, p. 23-24.
Karl, S.M., Friedman, R.M., Haeussler, P.J., Layer, P.W., and Baichtal, J.F., 2015b, Ages from Paleozoic intraoceanic volcanic arcs and overlapping Devonian continental clastic rocksImplications for the tectonic history of the southern Alexander terrane, Alaska: Geological Society of America, Abstracts with Programs, v. 47, p. 58.

Karl, S.M., Haeussler, P.J., Himmelberg, G.R., Zumsteg, C.L., Layer, P.W., Friedman, R.M., Roeske, S.M., and Snee, L.W., 2015c, Geologic map of Baranof Island, southeastern Alaska: U.S. Geological Survey Scientific Investigations Map 3335, pamphlet 82 p. [Also available at http://dx.doi.org/10.3133/ $\operatorname{sim} 3335$.

Karl, S.M., Haeussler, P.J., Layer, P., and Himmelberg, G.R., 1998, Two new events in the metamorphic and deformational history of the Alexander terrane on Admiralty Island, southeastern Alaska, in Karl, S.M., 1998, ed., Cutting edge in Alaska: Alaska Geological Society 1998 Science and Technology Conference, p. 15.

Karl, S.M., Jones, J.V., III, and Hayes, T.S., eds., 2016, GISbased identification of areas that have resource potential for critical minerals in six selected groups of deposit types in Alaska: U.S. Geological Survey Open-File Report 2016-1191, 99 p., 5 appendixes, 12 plates, scale 1:10,500,000. [Also available at http://dx.doi.org/10.3133/ofr20161191.]

Karl, S.M., Kreiner, D.C., Case, G.N.D., Labay, K.A., Shew, N.B., Granitto, M., Wang, B., and Anderson, E.D., 2021, Data and results for GIS-based identification of areas that have resource potential for lode gold deposits in Alaska: U.S. Geological Survey data release, https://doi.org/10.5066/ P9CAM3F9.

Karl, S.M., Layer, P.W., Ayuso, R.A., Haeussler, P.J., Zumsteg, C.L., Shew, N.B., Slack, J.F., and Bittenbender, P.E., 2005, Gold- and copper-bearing quartz veins associated with regional Devonian extensional deformation in rocks on Prince of Wales Island, southeastern Alaska, in Fowler, S.J., ed., Alaska Geological Society 2005 Geology Symposium: Alaska Geological Society, p. 18-19.

Karl, S.M., Layer, P.W., Harris, A.G., Haeussler, P.J., and Murchey, B.L., 2010a, The Cannery Formation-Devonian to early Permian arc-marginal deposits within the Alexander terrane, southeast Alaska, in Dumoulin, J.A., and Galloway, J.P., eds., Studies by the U.S. Geological Survey in Alaska, 2008-2009: U.S. Geological Survey Professional Paper 1776$\mathrm{B}, 45 \mathrm{p}$.

Karl, S.M. Newberry, R.J., Maas, K.M., and Snee, L.W., 2010b, Mid-Cretaceous terrane accretion, syndeformational intrusions, and orogenic gold in southeastern Alaska [abs.]: Anchorage, Alaska, Alaska Miners Association Annual Meeting, p. 5-6. 
Karl, S.M., Oswald, P.J., and Hults, C.P., 2015a, Field guide to the Mesozoic arc and accretionary complex of south central Alaska, Indian to Hatcher Pass: Alaska Geological Society, Cordilleran Section Geological Society of America Fieldtrip \#5, 65 p., 1 plate.

Kelley, K.D., Lang, J.R., and Eppinger, R.G., 2013, The giant Pebble $\mathrm{Cu}-\mathrm{Au}-\mathrm{Mo}$ deposit and surrounding region, southwest Alaska: Introduction: Economic Geology, v. 108, no. 3, p. $397-404$

Khashgerel, B.E., Kavalieris, I., and Hayashi, K.I., 2008, Mineralogy, textures, and whole-rock geochemistry of advanced argillic alteration-Hugo Dummett porphyry $\mathrm{Cu}-\mathrm{Au}$ deposit, Oyu Tolgoi mineral district, Mongolia: Mineralium Deposita, v. 43, p. 913-932. [Also available at https://doi. org/10.1007/s00126-008-0205-3.]

Krahulec, K., 2010, Sedimentary rock-hosted gold and silver deposits of the northeastern Basin and Range, Utah: Geological Society of Nevada Symposium, Great Basin Evolution and Metallogeny, v. 1-2, p. 31-62.

Kreiner, D.C., Jones, J.V., III, Todd, E., Holm-Denoma, C., Caine, J.S., and Benowitz, J., 2019, Links between tectonics, magmatism, and mineralization in the formation of Late Cretaceous porphyry systems in the Yukon-Tanana upland, eastern Alaska, USA: 15th SGA Biennial Meeting 2019, v. 2, p. 939-942.

Kurtak, J.M., Klieforth, R.F., Clark, J.M., and Maclean, E.A., 2002, Mineral investigations in the Koyukuk mining district, northern Alaska_Final Report: U.S. Bureau of Land Management Technical Report 50, 2 vols., 845 p.

Lang, J.R., and Baker, T., 2001, Intrusion-related gold systems:The present level of understanding: Mineralium Deposita, v. 36, p. 477-489.

Lang, J.R., Baker, T., Hart, C.J.R., and Mortensen, J.K., 2000, An exploration model for intrusion-related gold systems: Society of Economic Geologists Newsletter, v. 40, p. 1, 6-15.

Lang, J.R., Payne, J., Roberts, K., Reagliati, M., Oliver, J., and Roberts, K., 2013, Geology and magmatic-hydrothermal evolution of the giant Pebble porphyry copper-goldmolybdenum deposit, southwest Alaska: Economic Geology, v. 108 , p. $437-462$.

Langton, J.M., and Williams, S.A., 1982, Structural, petrological and mineralogical controls for the Dos Pobres ore body-Lone Star mining district, Graham County, Arizona, in Titley, S.R., ed., Advances in the geology of porphyry copper deposits, southwestern North America: Tucson, University of Arizona Press, p. 335-352.

LeBarge, W.P., and Coates, J., 2007, Yukon Placer Database 2007-Geology and mining activity of placer occurrences: Yukon Geological Survey, CD-ROM.
Lee, G.K., Yager, D.B., Mauk, J.L., Granitto, M., Denning, P., Wang, B., and Werdon, M.B., 2016, The geochemical atlas of Alaska, 2016: U.S. Geological Survey Data Series 908, 25 p., 272 sheets (11" $\times 17$ "), GIS database. [Also available at http:// dx.doi.org/10.3133/ds908.]

Lindgren, W., 1933, Mineral deposits (4th ed.): New York, McGraw Hill, 930 p.

Longo, A.A., 2005, Evolution of volcanism and hydrothermal activity in the Yanacocha mining district, northern Peru: Corvallis, Oregon State University, Ph.D. thesis, 325 p.

Maas, K.M., Bittenbender, P E., and Still, J.C., 1995, Mineral investigations in the Ketchikan mining district, southeastern Alaska: U.S. Bureau of Mines Open-File Report 11-95, 606 p.

Maloof, T.L., Baker, T., and Thompson, J.F., 2001, The Dublin Gulch intrusion-hosted gold deposit, Tombstone plutonic suite, Yukon Territory, Canada: Mineralium Deposita, v. 36, p. 583-593. [Also available at https://doi.org/10.1007/ s001260100190.]

Maydagán, L., Franchini, M., Rusk, B., Lentz, D.R., McFarlane, C., Impiccini, A., Ríos, F.J., and Rey, R., 2015, Porphyry to epithermal transition in the Altar $\mathrm{Cu}(\mathrm{Au}-\mathrm{Mo})$ deposit, Argentina, studied by cathodoluminescence, LA-ICP-MS, and fluid inclusion analysis: Economic Geology, v. 110, p. 889-923.

McCoy, D., Newberry, R.J., Layer, P., DiMarchi, J.J., Bakke, A., Masterman, J.S., and Minehane, D.L., 1997, Plutonic-related gold deposits of interior Alaska, in Goldfarb, R.J., and Miller, L.D., eds., Mineral deposits of Alaska: Economic Geology Monographs, v. 9, p. 191-241.

Miesch, A.T., 1976, Sampling designs for geochemical surveysSyllabus for a short course: U.S. Geological Survey Open-File Report 76-772, 128 p.

Miller, H.G., and Singh, V., 1994, Potential field tilt-A new concept for location of potential field sources: Journal of Applied Geophysics, v. 32, p. 213-217.

Miller, L.D., Barton, C.C., Fredericksen, R.S., and Bressler, J.R., 1992, Structural evolution of the Alaska-Juneau lode gold deposit, southeastern Alaska: Canadian Journal of Earth Sciences, v. 29, p. 865-878.

Miller, L.D., Glavinovich, P., and Sharp, J., 2015, NANA Regional Corporation identifies gold and base metal mineralization in the 70+ mile long Kugruk Mega Shear, or... the Fairhaven District, northern Seward Peninsula Alaska; the source of high grade Gold and a Hollywood actor!: Alaska Miners Association Annual Convention, p. 27.

Miller, L.D., Goldfarb, R.J., Gehrels, G.E., and Snee, L.W., 1994, Genetic links among fluid cycling, vein formation, regional deformation, and plutonism in the Juneau gold belt, southeastern Alaska: Geology, v. 22, p. 203-206. 
Miller, L.D., Goldfarb, R.J., Snee, L.W., Gent, C.A., and Kirkham, R.A., 1995, Structural geology, age, and mechanisms of gold vein formation at the Kensington and Jualin deposits, Berners Bay district, southeast Alaska: Economic Geology, v. 90, p. 343-368.

Miller, L.D., Stowell, H.H., and Gehrels, G.E., 2000, Progressive deformation associated with mid-Cretaceous to Tertiary contractional tectonism in the Juneau goldbelt, in Stowell, H.H., and McClelland, W.C., eds., Tectonics of the Coast Mountains, southeastern Alaska and British Columbia: Geological Society of America Special Paper 343, p. 193-212.

Miller, M.L., and Bundtzen, T.K., 1994, Generalized geologic map of the Iditarod quadrangle, Alaska showing potassium-argon, major oxide, trace element, fossil, paleocurrent, and archeological sample localities: U.S. Geological Survey Miscellaneous Field Studies Map MF-2219-A, 48 p., 1 sheet, scale 1:250,000.

Miller, T.P., 1989, Contrasting plutonic rock suites of the YukonKoyukuk basin and the Ruby geanticlines, Alaska: Journal of Geophysical Research, v. 94, no. B11, p. 15969-15987.

Miller, T.P., and Elliott, R.L., 1969, Metalliferous deposits near Granite Mountain, eastern Seward Peninsula, Alaska: U.S. Geological Survey Circular 614, 19 p.

Moll-Stalcup, E.J., 1994, Latest Cretaceous and Cenozoic magmatism in mainland Alaska, in Plafker, G., and Berg, H.C., eds., The geology of Alaska: Geological Society of America, The Geology of North America, v. G-1, p. 589-619.

Moore, T.E., Wallace, W.K., Bird, K.J., Karl, S.M., Mull, C.G., and Dillon, J.T., 1994, Geology of northern Alaska, in Plafker, G., and Berg, H.C., eds., The geology of Alaska: Geological Society of America, The Geology of North America, DNAG, v. G-1, p. 49-140.

Morelli, R.M., Bell, C.C., Creaser, R.A., and Simonetti, A., 2010, Constraints on the genesis of gold mineralization at the Homestake gold deposit, Black Hills, South Dakota, from rheniumosmium sulfide geochronology: Mineralium Deposita, v. 45, p. 461-480.

Muntean, J.L., Cline, J.S., Simon, A.C., and Longo, A.A., 2011, Magmatic-hydrothermal origin of Nevada's Carlin-type gold deposits: Nature Geoscience, v. 4, p. 122-127. [Also available at https://doi.org/10.1038/ngeo1064.]

Muntean, J.L., and Einaudi, M.T., 2000, Porphyry gold deposits of the Refugio district, Maricunga belt, northern Chile: Economic Geology, v. 95, p. 1445-1472.

Muntean, J.L., and Einaudi, M.T., 2001, Porphyry-epithermal transition-Maricunga belt, northern Chile: Economic Geology, v. 96, p. 743-772. [Also available at https://doi. org/10.2113/gsecongeo.96.4.743.]

Nelson, C.E., 2000, Volcanic domes and gold mineralization in the Pueblo Viejo district, Dominican Republic: Mineralium Deposita, v. 35, p. 511-525.
Newberry, R.J., and Brew, D.A., 1987, The Alaska-Juneau gold deposit; remobilized syngenetic versus exotic epigenetic origin, 1987, in Hamilton, T.D., and Galloway, J.P., eds., Geologic studies in Alaska by the U.S. Geological Survey during 1986: U.S. Geological Survey Circular 998, p. 128-131.

Newberry, R.J., McCoy, D.C., and Brew, D.A., 1995, Plutonichosted gold ores in Alaska-Igneous vs. metamorphic origins: Mining Geology Japan, special issue, v. 28, p. 57-100.

Nokleberg, W.J., Bundtzen, T.K., Berg, H.C., Brew, D.A., Grybeck, D., Robinson, M.S., Smith, T.E., and Yeend, W., 1987, Significant metalliferous lode deposits and placer deposits of Alaska: U.S. Geological Survey Bulletin 1786, 104 p.

Otto, B.R., Piekenbrock, J., and Odden, J., 2009, Structural evolution of the Rock Creek gold deposit, Seward Peninsula, Alaska: Economic Geology, v. 104, p. 945-960. [Also available at https://doi.org/10.2113/econgeo.104.7.945.]

Park, F.C., 1933, The Girdwood District, Alaska: U.S. Geological Survey Bulletin 849-G, p. 381-424.

Parry, W.T., Jasumback, M., and Wilson, P.N., 2002, Clay mineralogy of phyllic and intermediate argillic alteration at Bingham, Utah: Economic Geology, v. 97, p. 221-239.

Patton, W.W., Jr., and Box, S.E., 1989, Tectonic setting of the Yukon-Koyukuk basin and its borderlands, western Alaska: Journal of Geophysical Research, v. 94, no B11, p. 1580715820 .

Phillips, G.N., and Hughes, M.J., 1996, The geology and gold deposits of the Victorian gold province: Ore Geology Reviews, v. 11, p. 255-302.

Pink, C.L., 2010, Structural controls on gold mineralization at the Rock Creek Deposit, Nome, Alaska - Implications for middle Cretaceous lode emplacement on the southwest Seward Peninsula: Pocatello, Idaho, Idaho State University, M.S. thesis, $227 \mathrm{p}$.

Pitcairn, I.K., Teagle, D.A.H., Craw, D., Olivo, G.R., Kerrich, R., and Brewer, T.S., 2006, Sources of metals and fluids in orogenic gold deposits - Insights from the Otago and Alpine schists, New Zealand: Economic Geology, v. 101, p. 15251546.

Plafker, G., and Berg, H.C., 1994, Overview of the geology and tectonic evolution of Alaska, in Plafker, G., and Berg, H.C., eds., The Geology of Alaska: Geological Society of America, The Geology of North America, v. G-1, p. 989-1021.

Porterfield, B., 2000, The Terra gold prospect, Alaska Range, Alaska [abs.]: Alaska Miners Association 17th Biennial Conference on Alaska Mining, p. 58-63.

Ray, J.C., 1954, Geology and ore deposits of the Willow Creek mining district, Alaska: U.S. Geological Survey Bulletin $1004,86 \mathrm{p}$. 
Reed, B.L., and Lanphere, M.A., 1972, Generalized geologic map of the Alaska-Aleutian Range batholith showing K-Ar ages of the plutonic rocks: U.S. Geological Survey Miscellaneous Field Studies Map MF-372, 2 sheets, scale 1:1,000,000.

Rhys, D., DiMarchi, J., Smith, M., Friesen, R., and Rombach, C., 2003, Structural setting, style and timing of vein-hosted gold mineralization at the Pogo deposit, east central Alaska: Mineralium Deposita, v. 38, p. 863-875.

Richter, D.H., Singer, D.A., and Cox, D.P., 1975, Mineral resources map of the Nabesna quadrangle, Alaska: U.S. Geological Survey Miscellaneous Field Studies Map MF-655-K, 1 sheet, scale 1:250,000.

Ridgway, K.D., Trop, J.M., Nokleberg, W.J., Davidson, C.M., and Eastham, K.D., 2002, Mesozoic and Cenozoic tectonics of the eastern and central Alaska Range-Progressive basin development and deformation within a suture zone: Geological Society of America Bulletin, v. 114, p. 1480-1504.

Rioux, M., Hacker, B.R., Mattinson, J., Kelemen, P.J., Blusztajn, J., and Gehrels, G.E., 2007, Magmatic development of an intraoceanic arc-High precision U-Pb zircon and whole-rock isotopic analysis from the accreted Talkeetna arc, south central Alaska: Geological Society of America Bulletin, v. 119, p. 1168-1184.

Roeske, S.M., Dusel-Bacon, C., Aleinikoff, J.N., Snee, L.W., and Lanphere, M.A., 1995, Metamorphic and structural history of continental crust at a Mesozoic collisional margin, the Ruby terrane, central Alaska: Journal of Metamorphic Geology, v. 13 , p. $25-40$.

Rombach, C.S. and Newberry, R.J, 2001, Shotgun depositGranite porphyry-hosted gold-arsenic mineralization in southwestern Alaska, USA: Mineralium Deposita, v. 36, p. $607-621$.

Rush, P.M., and Seegers, H.J., 1990, Ok Tedi copper-gold deposits: Australasian Institute of Mining and Metallurgy, Monograph 14, v. 2, p. 1747-1754.

Sack, P.J., Karl, S.M., Steeves, N., and Gemmell, J.B., 2016, Volcanogenic massive sulphide and orogenic gold deposits of northern southeast Alaska: Geological Association of CanadaMineralogical Association of Canada Annual conference, Fieldtrip 5 Guidebook, 75 p., 1 plate.

Sainsbury, C.L., and MacKevett, E.M., Jr., 1965, Quicksilver deposits of southwestern Alaska: U.S. Geological Survey Bulletin $1187,89 \mathrm{p}$.

Saltus, R.W., Hudson, T.L., and Wilson, F.H., 2007, The geophysical character of southern Alaska-Implications for crustal evolution, in Ridgway, K.D., Glen, J.M.G., and O’Neill, J.M., eds., Tectonic growth of a collisional continental marginCrustal evolution of southern Alaska: Geological Society of America Special Paper 431, p. 1-20.
Saltus, R.W., and Simmons, G.C. 1997, Composite and merged aeromagnetic data for Alaska-A web site for distribution of gridded data and plot files: U.S. Geological Survey Open-File Report 97-520, 15 p. [Also available at https://pubs.er.usgs. gov/publication/ofr97520.]

Sawkins, F.J., 1990, Metal deposits in relation to plate tectonics: Berlin, Springer-Verlag Berlin Heidelberg, 461 p.

Seedorff, E., 2000, Summary of the gold-silver deposits of the Robinson district, with descriptions of the Northwest Ruth, J.D. Hill, and Star Pointer deposits, in Gans, P.B., and Seedorff, E., eds., Cenozoic tectono-magmatic evolution of White Pine County, Nevada - Core complexes, Eocene-Oligocene volcanic centers, episodic extension and shortening, and disseminated gold deposits: Geological Society of Nevada Symposium 2000, Fieldtrip guidebook 11, p. 141-166.

Seedorff, E., Dilles, J.H., Proffett, J.M., Jr., Einaudi, M.T., Zurcher, L., Stavast, W.J.A., Johnson, D.A., and Barton, M.D., 2005, Porphyry deposits - Characteristics and origin of hypogene features, in Hedenquist, J.W., Thompson, J.F.H., Goldfarb, R.J., and Richards, J.P., eds., Economic GeologyOne hundredth anniversary volume, 1905-2005: Society of Economic Geologists, p. 251-298.

Selby, D., Creaser, R.A., Hart, J.R., Rombach, C.S., Thompson, J.F.H., Smith, M.T., Bakke, A.A., and Goldfarb, R.J., 2002, Absolute timing of sulfide and gold mineralization-A comparison of Re-Os molybdenite and Ar-Ar mica methods from the Tintina gold belt, Alaska: Geology, v. 30, no. 9, p. 791-794.

Shacklette, H.T., and Boerngan, J.G., 1984, Element concentrations in soils and other surficial materials in the conterminous United States: U.S. Geological Survey Professional Paper 1270, 105 p. [Also available at https://doi.org/10.3133/pp1270.]

Sillitoe, R.H., 1973, The tops and bottoms of porphyry copper deposits: Economic Geology, v. 68, p. 799-815.

Sillitoe, R.H., 1997, Characteristics and controls of the largest porphyry copper-gold and epithermal gold deposits in the circum-Pacific region: Australian Journal of Earth Sciences, v. 44, p. 373-388.

Sillitoe, R.H., 2008, Major gold deposits and belts of the North and South American cordillera-Distribution, tectonomagmatic settings, and metallogenic considerations: Economic Geology, v. 103, p. 663-687.

Sillitoe, R.H., 2010, Porphyry copper systems: Economic Geology, v. 105, p. 3-41. [Also available at https://doi.org/10.2113/ gsecongeo.105.1.3.]

Sillitoe, R.H., and Hedenquist, J.W., 2003, Linkages between volcanotectonic settings, ore-fluid compositions and epithermal precious metal deposits, in Simmons, S.F., and Graham, I., eds., Volcanic, geothermal and ore-forming fluids - Rulers and witnesses of processes within the Earth: Economic Geology, Special Publication 343, 73 p. 
Simmons, S.F., 1991, Hydrologic implications of alteration and fluid inclusion studies in the Fresnillo district-Evidence for a descending water table and a brine reservoir during formation of hydrothermal Ag-Pb-Zn deposits: Economic Geology, v. 86, p. 1579-1602.

Simmons, S.F., White, N.C., and John, D.A., 2005, Geological characteristics of epithermal precious and base metal deposits, in Hedenquist, J.W., Thompson, J.F.H., Goldfarb, R.J., and Richards, J.P., eds., Economic Geology— One hundredth anniversary volume, 1905-2005: Society of Economic Geologists, p. 485-522.

Singer, D.A., 1999, Classifying the Shumagin and Alaska Apollo deposits, in Riehle, J.R., ed., A geological and geophysical setting of the gold-silver vein system of Unga Island, southwestern Alaska: U.S. Geological Survey Open-File Report 99-136, 6 p., CD-ROM.

Smith, D.B., Smith, S.M., and Horton, J.D., 2013, History and evaluation of national-scale geochemical datasets for the United States: Geoscience Frontiers, v. 4, no. 2, p. 167-183.

Smith, M.T., Thompson, J.F.H., Moore, K.H., Bressler, J.R., Layer, P., Mortensen, J.K., Abe, I., and Takoaka, H., 2000, The Liese Zone, Pogo property-A new high-grade gold deposit in Alaska, in Tucker, T.L., and Smith, M.T., eds., The Tintina gold belt - Concepts, exploration and discoveries: British Columbia-Yukon Chamber of Mines, Cordilleran Round-Up Special Volume 2, p. 131-144.

Stoffregen, R., 1987, Genesis of acid-sulfate alteration and Au$\mathrm{Cu}-\mathrm{Ag}$ mineralization at Summitville, Colorado: Economic Geology, v. 82, p. 1575-1591.

Swainbank, R.C., Smith, T.E., and Turner, D.L., 1977, Geology and $\mathrm{K}$-Ar age of mineralized intrusive rocks from the Chulitna mining district, central Alaska-Short notes on Alaskan geology-1977: Alaska Division of Geological \& Geophysical Surveys Geologic Report 55, p. 23-28.

Szumigala, D.J., Dodd, S.P., and Arribas, A., Jr., 2000, Geology and gold mineralization at the Donlin Creek prospects, southwestern Alaska: Alaska Division of Geological \& Geophysical Surveys Professional Report 119, p. 91-115.

Szumigala, D.J., Harbo, L.A., and Adleman, J.N., 2011, Alaska's mineral industry 2010: Alaska Division of Geological \& Geophysical Surveys Special Report 65, 83 p. [Also available at http://doi.org/10.14509/22822.]

Taggart, J.E., ed., 2002, Analytical methods for chemical analysis of geologic and other materials: U.S. Geological Survey OpenFile Report 02-223, variously paged. [Also available at http:// pubs.usgs.gov/of/2002/ofr-02-0223/.]

Taylor, C.D., 2003, Descriptions of mineral occurrences and interpretation of mineralized rock geochemical data in the Stikine geophysical survey area, southeastern Alaska: U.S. Geological Survey Open-File Report 2003-154, 51 p.
Taylor, R.B., and Steven, T.A., 1983, Definition of mineral resource potential: Economic Geology, v. 78, p. 1268-1270.

Taylor, R.D., Graham, G.E., Anderson, E.D., and Selby, D., 2014, Timing of ore-related magmatism in the western Alaska Range, southwestern Alaska: U.S. Geological Survey OpenFile Report 2014-1115, 25 p. [Also available at http://dx.doi. org/10.3133/ofr20141115.]

Thompson, J.F.H., and Newberry, R.J., 2000, Gold deposits related to reduced granitic intrusions: Reviews in Economic Geology, v. 13, p. 377-400.

Thompson, J.F.H., Sillitoe, R.H., Baker, T., Lang, J.R., and Mortensen, J.K., 1999, Intrusion related gold deposits associated with tungsten-tin provinces: Mineralium Deposita, v. 34, p. 323-334. [Also available at https://doi.org/10.1007/ s001260050207.]

Till, A.B., Dumoulin, J.A., Werdon, M.B., and Bleick, H.A., 2011, Bedrock geologic map of the Seward Peninsula, Alaska, and accompanying conodont data: U.S. Geological Survey Scientific Investigations Map 3131, 2 sheets, scale 1:500,000, 75 p.

Tomkins, A.G., 2013, On the source of orogenic gold: Geology, v. 41, p. $1255-1256$.

Tosdal, R.M., and Richards, J.P., 2001, Magmatic and structural controls on the development of porphyry $\mathrm{Cu} \pm \mathrm{Mo} \pm \mathrm{Au}$ deposits, in Richards, J.P., and Tosdal, R.M., eds., Structural controls on ore genesis: Reviews in Economic Geology, v. 14, p. 157-180.

Twenhofel, W.S., 1952, Geology of the Alaska-Juneau lode system, Alaska: U.S. Geological Survey Open-File Report 60, 170 p.

U.S. Geological Survey, [undated], Alaska Resource Data File (ver. 1.7, March 2018): U.S. Geological Survey database, last accessed December 2019, at https://mrdata.usgs.gov/ardf/.

Vallier, T.L., Scholl, D.W., Fisher, M.A., Bruns, T.R., Wilson, F.H., von Huene, R., and Stevenson, A.J., 1994, Geologic framework of the Aleutian arc, Alaska: Geological Society of America, Geology of North America, v. G1, p. 367-388.

Verduzco, B., Fairhead, J.D., Green, C.M., and MacKenzie, C., 2004, New insights into magnetic derivatives for structural mapping: Leading Edge, v. 23, p. 116-119.

Wedepohl, K.H., 1995, The composition of the continental crust: Geochimica et Cosmochimica Acta, v. 59, p. 1217-1232. [Also available at https://doi.org/10.1016/0016-7037(95)00038-2.]

Wenz, Z.D., 2004, Geology and gold mineralization of the Nyac district, southwest Alaska: Fairbanks, University of Alaska, M.S. thesis, $153 \mathrm{p}$.

White, N.C., and Hedenquist, J.W., 1990, Epithermal environments and styles of mineralization - Variations and their causes, and guidelines for exploration: Journal of Geochemical Exploration, v. 36, p. 445-474. 
White, W.H., and Queen, L.D., 1989, Preliminary geologic and rock-chip geochemical data from drill core and trenches at the Shumagin gold deposit, Unga Island, Alaska: U.S. Geological Survey Open-File Report 89-361, 11 p.

Wilson, F.H., 1985, The Meshik arc-An Eocene to earliest Miocene magmatic arc on the Alaska Peninsula: Alaska Division of Geological \& Geophysical Surveys Professional Report 88, 14 p.

Wilson, F.H., Case, J.E., and Detterman, R.L., 1985, Preliminary description of a Miocene zone of structural complexity in the Port Moller and Stepovak Bay quadrangles, Alaska: U.S. Geological Survey Circular 945, p. 55-56.

Wilson, F.H., Hults, C.P., Mull, C.G., and Karl, S.M., compilers, 2015, Geologic map of Alaska: U.S. Geological Survey Scientific Investigations Map 3340, 2 sheets, scale 1:1,584,000, pamphlet 196 p. [Also available at http://dx.doi.org/10.3133/sim3340.]

Wilson, F.H., and Shew, N.B., 1992, Map and tables showing geochronology and whole rock geochemistry of selected samples, Ugashik and part of Karluk quadrangles, Alaska: U.S. Geological Survey Miscellaneous Field Studies Map MF1539-E, scale 1:250,000.

Wilson, F.H., White, W.H., and DuBois, G.D., 1988, Brief descriptions of mines, prospects, and mineral occurrences in the Port Moller and Stepovak Bay quadrangles, Alaska Peninsula: U.S. Geological Survey Open-File Report 88-666, 128 p.
Winkler, H.G.F., 1976, Petrogenesis of metamorphic rocks: New York, Springer-Verlag, 334 p.

Yao, Y., Morteani, G., and Trumbull, R.B., 1999, Fluid inclusion microthermometry and the P-T evolution of gold-bearing hydrothermal fluids in the Niuxinshan gold deposit, eastern Hebei Province, NE China: Mineralium Deposita v. 34, p. $348-365$.

Yeend, W.E., 1996, Gold placers of the historical Fortymile River region, Alaska: U.S. Geological Survey Bulletin 2125, 75 p., 1 sheet, scale 1:63,360.

Yesilyurt, S., 1995, Geology, geochemistry, and mineralization of the Liberty Bell gold mine area, Alaska, in Coyner, A.R., and Fahey, P.L., eds., Geology and ore deposits of the American Cordillera: Symposium Proceedings, Reno/Sparks, Nevada, April 1995, p. 1281-1316.

Young, L.E., St. George, P., and Bouley, B.E., 1997, Porphyry copper deposits in relation to the magmatic history and palinspastic restoration of Alaska: Economic Geology Monographs, v. 9 , p. 306-333.

Zumsteg, C.L., Karl, S.M., Haeussler, P.J., and Himmelberg, G.R., 2004, Recognition of three metamorphic events within the Wales Group on Prince of Wales and Dall Islands, southeastern Alaska [abs.]: Geological Society of America, Abstracts with Programs, v. 36, no. 5, p. 135.

Publishing support by the Moffett Field Publishing Service Center, California

Manuscript approved April 5, 2021

Edited by Katherine Jacques and Mitchell Phillips

Layout by Katie Sullivan 


\section{Appendix 1. Statistical Calculations of Levels of Background Values for Sediment and Rock Geochemical Data}

Appendix 1 is available online at http://doi.org/10.3133/ofr20211041.

\section{Appendix 2. Alaska Resource Data File (ARDF) Mineral-Deposit-Keyword-and- Scoring Templates}

The Alaska Resource Data File (ARDF, https://mrdata. usgs.gov/ardf/; U.S. Geological Survey, undated) contains more than 7,000 reports of mines, prospects, and mineral occurrences in Alaska. The ARDF records, which are published for individual U.S. Geological Survey (USGS) 1:250,000-scale quadrangles, are available as USGS Open-File Reports that may be downloaded individually or as a single composite ARDF database. The ARDF records represent a broad spectrum of mineral deposit types, so we developed a method to search for records that were most likely to represent each of the six deposit models examined in this study. The search terms used to query each deposit model are listed in the following spreadsheets, organized by deposit type: "Undivided_ARDF_keywords," "Orogenic_ARDF_keywords," "Intrusion-related_ARDF _keywords," "Epithermal_ARDF_keywords," "AuPorphyry_ ARDF_keywords," and "Intrusion_Oro_ARDF_keywords."
For each deposit type, a list of searchable keywords was developed for key ARDF-record fields (shown in "ARDF Field Name" row). Using a custom Python script in ArcGIS, all ARDF records were searched and assigned a total score based on the associated weight values ("_WGT") of all the keywords found in the record. In some cases, keywords were assigned negative scores if they were indicative of a geological system known to be not associated with the mineral deposit of interest.

The success of this scoring method for identifying relevant ARDF records was assessed by comparing the scored records for certain areas with areas of known mineral potential and (or) mining activity. In some cases, scoring values were adjusted and the script was run again to better calibrate the ARDF scoring process and optimize the results.

\section{Appendix 3. Lithology-Keyword Search Terms for the "Geologic Map of Alaska"}

A lithology-keyword search of the database for the "Geologic map of Alaska" (Wilson and others, 2015) was used in this study. The "Geologic map of Alaska" portrays the distribution of different rock types across the State of Alaska. For most mineral-deposit types, we used the lithology-code field in the geologic map database to identify rock types that were the most prospective and (or) the best suited for hosting that deposit type. The lithology-field query results were used to develop derivative, generalized lithology layers that show the distribution of favorable rock types for each deposit type across the State. The specific lithology search terms used to query each deposit model are listed in the following spreadsheets, organized by lithology layer: "felsic_plut," felsic_volc_hyp," "intermediate_plut," "intermediate_volc_hyp," "lamprophyre," "o_carbonaceous," "o_mbas_amphsch," and "o_micasch_qtzfeldsch."

\section{Reference Cited}

Wilson, F.H., Hults, C.P., Mull, C.G., and Karl, S.M., compilers, 2015, Geologic map of Alaska: U.S. Geological Survey Scientific Investigations Map 3340, 2 sheets, scale 1:1,584,000, pamphlet 196 p., [Also available at http:// dx.doi.org/10.3133/sim3340.] 


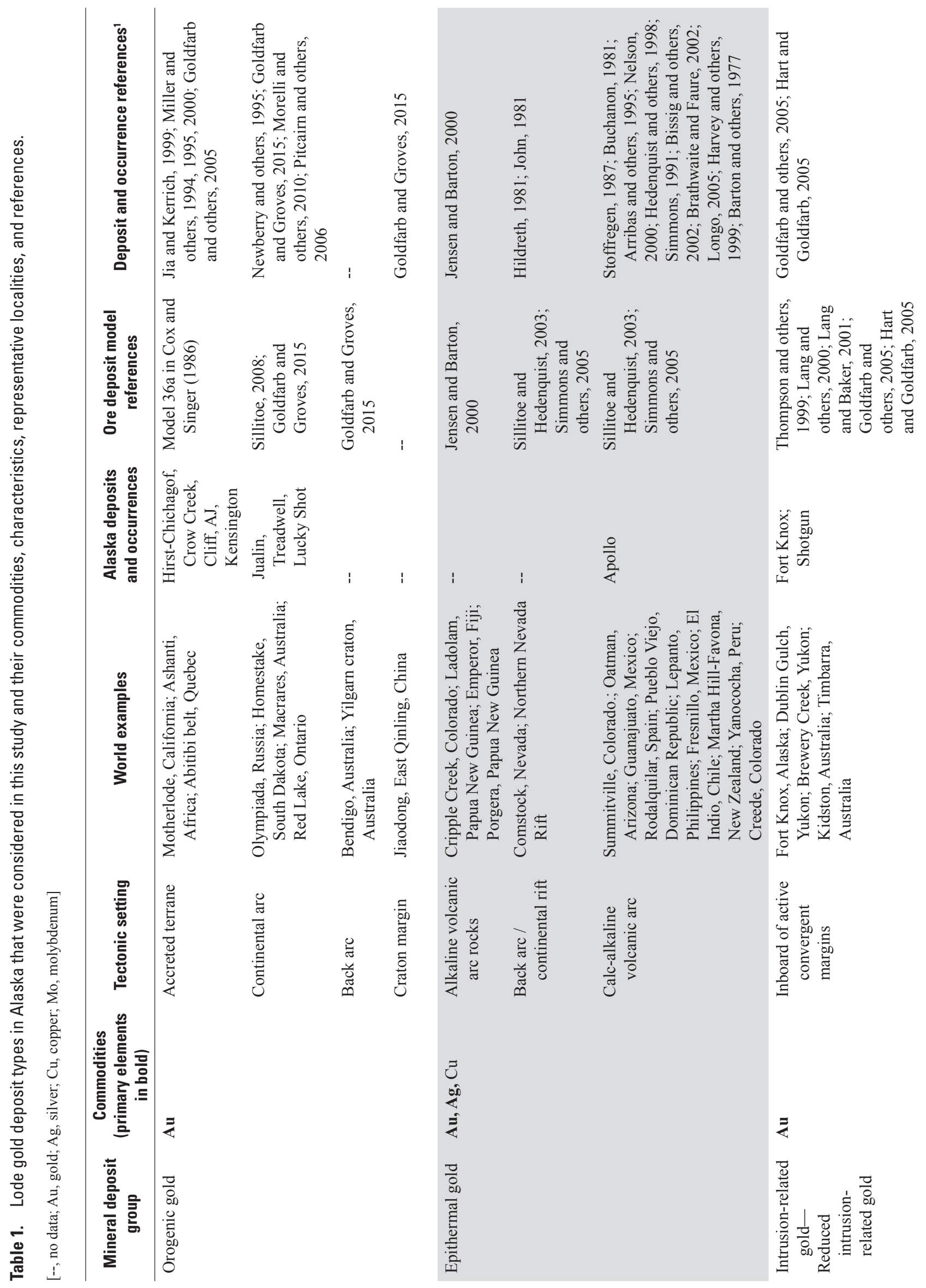




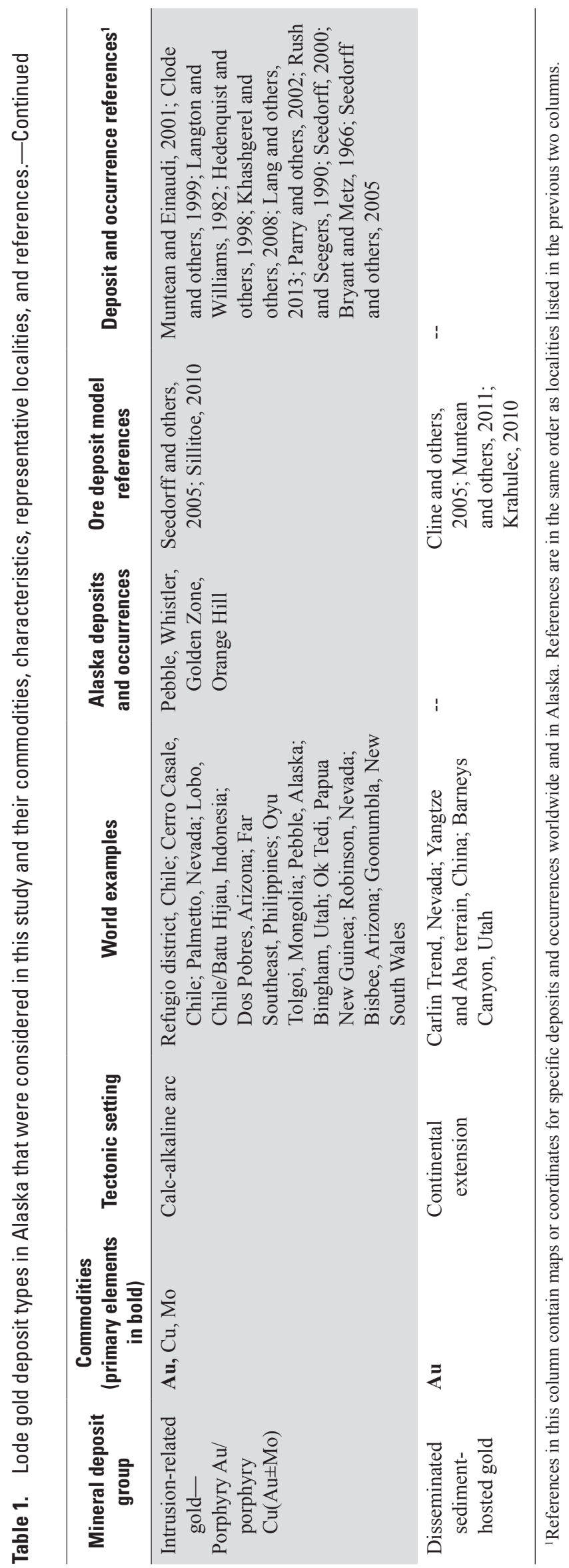


Table 2. Scoring template for analysis of undivided lode gold potential within each hydrologic unit code (HUC) in Alaska.

[AGDB3, Alaska Geochemical Database, version 3.0; ARDF, Alaska Resource Data File; bkg, background concentration (see appendix 1); HMC, heavy mineral concentrate; ppm, parts per million; Ag, silver; As, arsenic; $\mathrm{Au}$, gold; $\mathrm{Bi}$, bismuth; $\mathrm{Cu}$, copper; $\mathrm{Hg}$, mercury; Mo, molybdenum; $\mathrm{Pb}$, lead; $\mathrm{Sb}$, antimony; $\mathrm{Se}$, selenium; Te, tellurium; Tl, thallium; W, tungsten; Zn, zinc]

\begin{tabular}{|c|c|c|c|}
\hline Category & Dataset/layer & Component & Selection and score \\
\hline Lithology ${ }^{1}$ & $\begin{array}{l}\text { Geologic map of } \\
\text { Alaska (Wilson and } \\
\text { others, 2015) }\end{array}$ & (LITHOLOGY_SCORE) & $\begin{array}{l}3 \text { points if felsic-hypabyssal or hypabyssal-basalt } \\
3 \text { points if andesite or hypabyssal andesite } \\
3 \text { points if granite or granodiorite } \\
3 \text { points if diorite, monzonite, or quartz-monzonite } \\
3 \text { points if mica-schist or quartz-feldspar-schist } \\
3 \text { points if metabasalt or amphibole-schist } \\
3 \text { points if carbonaceous metasedimentary } \\
3 \text { points if lamprophyre }\end{array}$ \\
\hline ARDF records ${ }^{2}$ & ARDF & Lode gold model keywords & $\begin{array}{l}5 \text { points if lode } \mathrm{Au} \text { keyword total score }>83 \\
3 \text { points if lode } \mathrm{Au} \text { keyword total score }>50 \text { and } \leq 83 \\
1 \text { point if lode } \mathrm{Au} \text { keyword total score }>25 \text { and } \leq 50\end{array}$ \\
\hline \multirow[t]{10}{*}{$\begin{array}{l}\text { Rock geochemical } \\
\text { data }^{3}\end{array}$} & AGDB3 & $\begin{array}{l}\mathrm{Au}>15.5 \mathrm{x}, 7.5 \mathrm{x}, 3.5 \mathrm{x} \text {, or } 1.5 \mathrm{x} \text { bkg } \\
\left(\mathrm{RCK} \_\mathrm{AU} \_\mathrm{SCORE}\right)\end{array}$ & $\begin{array}{l}6 \text { points if } \mathrm{Au} \_ \text {ppm } \geq 0.03875 \\
4 \text { points if } \mathrm{Au} \_ \text {ppm } \geq 0.01875 \text { and }<0.03875 \\
2 \text { points if } \mathrm{Au} \text { _ppm } \geq 0.00875 \text { and }<0.01875 \\
1 \text { point if } \mathrm{Au} \text { _ppm } \geq 0.00375 \text { and }<0.00875\end{array}$ \\
\hline & & $\begin{array}{l}\mathrm{Ag}>15.5 \mathrm{x}, 7.5 \mathrm{x}, 3.5 \mathrm{x} \text {, or } 1.5 \mathrm{x} \text { bkg } \\
\left(\mathrm{RCK} \_ \text {AG_SCORE) }\right.\end{array}$ & $\begin{array}{l}6 \text { points if } \mathrm{Ag} \_ \text {ppm } \geq 1.085 \\
4 \text { points if } \mathrm{Ag} \_ \text {ppm } \geq 0.525 \text { and }<1.085 \\
2 \text { points if } \mathrm{Ag} \_ \text {ppm } \geq 0.245 \text { and }<0.525 \\
1 \text { point if } \mathrm{Ag} \_ \text {ppm } \geq 0.105 \text { and }<0.245\end{array}$ \\
\hline & & $\begin{array}{l}\text { As }>15.5 x, 7.5 x, 3.5 x \text {, or } 1.5 x \text { bkg } \\
\text { (RCK_AS_SCORE) }\end{array}$ & $\begin{array}{l}6 \text { points if As_ppm } \geq 26.35 \\
4 \text { points if As_ppm } \geq 12.75 \text { and }<26.35 \\
2 \text { points if As_ppm } \geq 5.95 \text { and }<12.75 \\
1 \text { point if As_ppm } \geq 2.55 \text { and }<5.95\end{array}$ \\
\hline & & $\begin{array}{c}\text { As }>15.5 \mathrm{x} \text { bkg with } \mathrm{Cu}, \mathrm{Zn} \text {, or } \mathrm{Pb} \\
\quad>15.5 \mathrm{x}, 7.5 \mathrm{x}, 3.5 \mathrm{x} \text {, or } 1.5 \mathrm{x} \text { bkg }\end{array}$ & $\begin{array}{l}6 \text { points if } \mathrm{As} \_ \text {ppm }>26.35 \text { and }\left(\mathrm{Cu} \_ \text {ppm }>387.5 \text { or }\right. \\
\left.\mathrm{Zn} \_ \text {ppm }>1007.5 \text { or } \mathrm{Pb} \_ \text {ppm }>229.4\right)\end{array}$ \\
\hline & & & $\begin{array}{l}1 \text { point if } \mathrm{As} \_ \text {ppm }>26.35 \text { and }\left(\left(\mathrm{Cu} \_ \text {ppm }>37.5 \text { and }\right.\right. \\
\leq 87.5) \text { or }\left(\mathrm{Zn} \_ \text {ppm }>97.5 \text { and } \leq 227.5\right) \text { or }\left(\mathrm{Pb} \_ \text {ppm }\right. \\
>22.2 \text { and } \leq 51.8))\end{array}$ \\
\hline & & $\begin{array}{l}\mathrm{Hg}>15.5 \mathrm{x}, 7.5 \mathrm{x}, 3.5 \mathrm{x} \text {, or } 1.5 \mathrm{x} \text { bkg } \\
(\mathrm{RCK} \text { _HG_SCORE) }\end{array}$ & $\begin{array}{l}6 \text { points if } \mathrm{Hg} \_ \text {ppm } \geq 0.62 \\
4 \text { points if } \mathrm{Hg} \_ \text {ppm } \geq 0.3 \text { and }<0.62 \\
2 \text { points if } \mathrm{Hg} \_ \text {ppm } \geq 0.14 \text { and }<0.3 \\
1 \text { point if } \mathrm{Hg} \_ \text {ppm } \geq 0.06 \text { and }<0.14\end{array}$ \\
\hline & & $\begin{array}{l}\mathrm{Sb}>15.5 \mathrm{x}, 7.5 \mathrm{x}, 3.5 \mathrm{x}, \text { or } 1.5 \mathrm{x} \text { bkg } \\
\left(\mathrm{RCK} \_\mathrm{SB} \_\mathrm{SCORE}\right)\end{array}$ & $\begin{array}{l}6 \text { points if } \mathrm{Sb} \_ \text {ppm } \geq 4.65 \\
4 \text { points if } \mathrm{Sb} \_ \text {ppm } \geq 2.25 \text { and }<4.65 \\
2 \text { points if } \mathrm{Sb} \_ \text {ppm } \geq 1.05 \text { and }<2.25 \\
1 \text { point if } \mathrm{Sb} \_ \text {ppm } \geq 0.45 \text { and }<1.05\end{array}$ \\
\hline & & $\begin{array}{l}\text { Te }>15.5 x, 7.5 x, 3.5 x \text {, or } 1.5 x \text { bkg } \\
\text { (RCK_TE_SCORE) }\end{array}$ & $\begin{array}{l}6 \text { points if Te_ppm } \geq 0.0775 \\
4 \text { points if } \mathrm{Te} \_ \text {ppm } \geq 0.0375 \text { and }<0.0775\end{array}$ \\
\hline & & & 2 points if Te_ppm $\geq 0.0175$ and $<0.0375$ \\
\hline & & & 1 point if Te_ppm $\geq 0.0075$ and $<0.0175$ \\
\hline
\end{tabular}


Table 2. Scoring template for analysis of undivided lode gold potential within each hydrologic unit code (HUC) in Alaska. —Continued

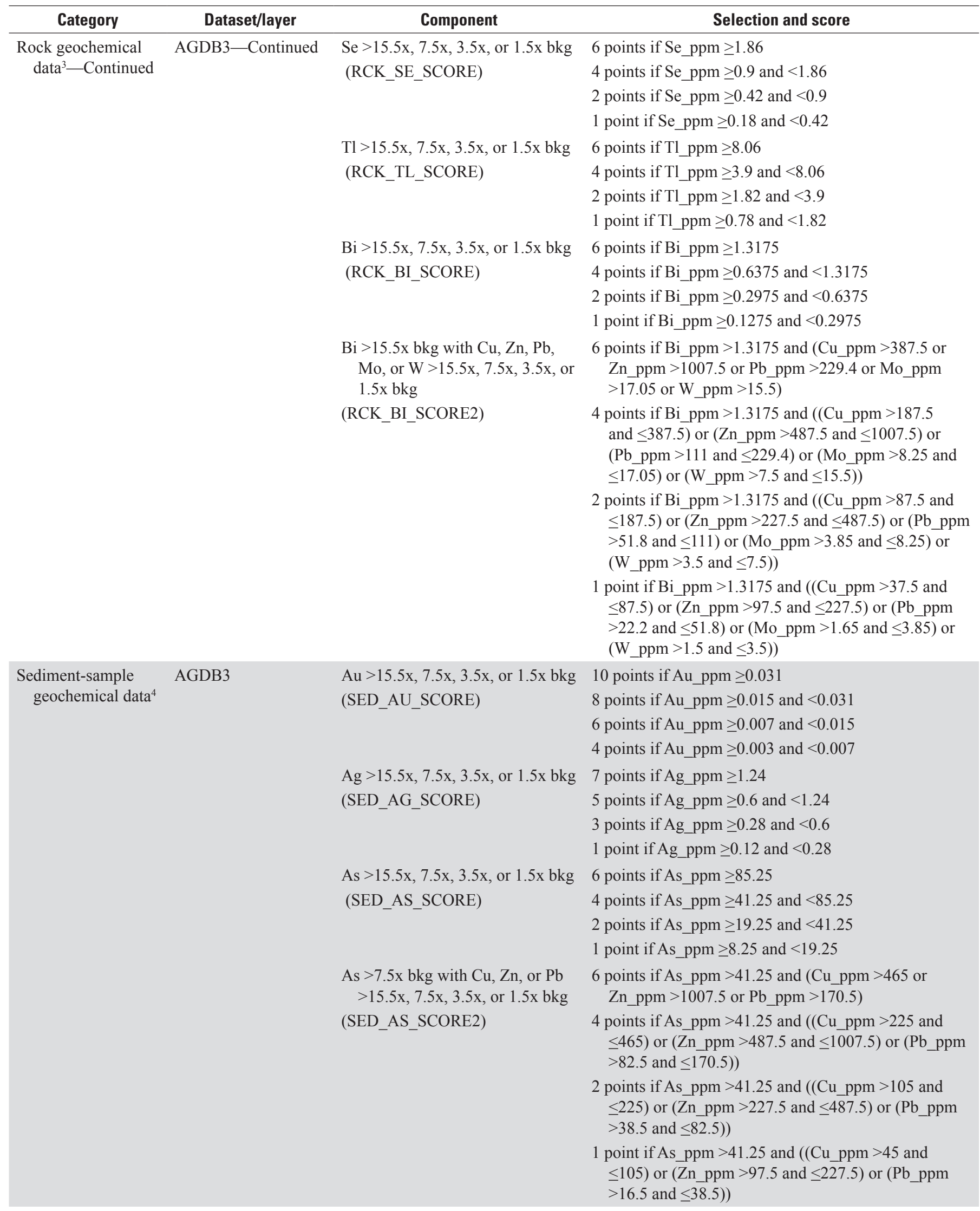


Table 2. Scoring template for analysis of undivided lode gold potential within each hydrologic unit code (HUC) in Alaska.—Continued

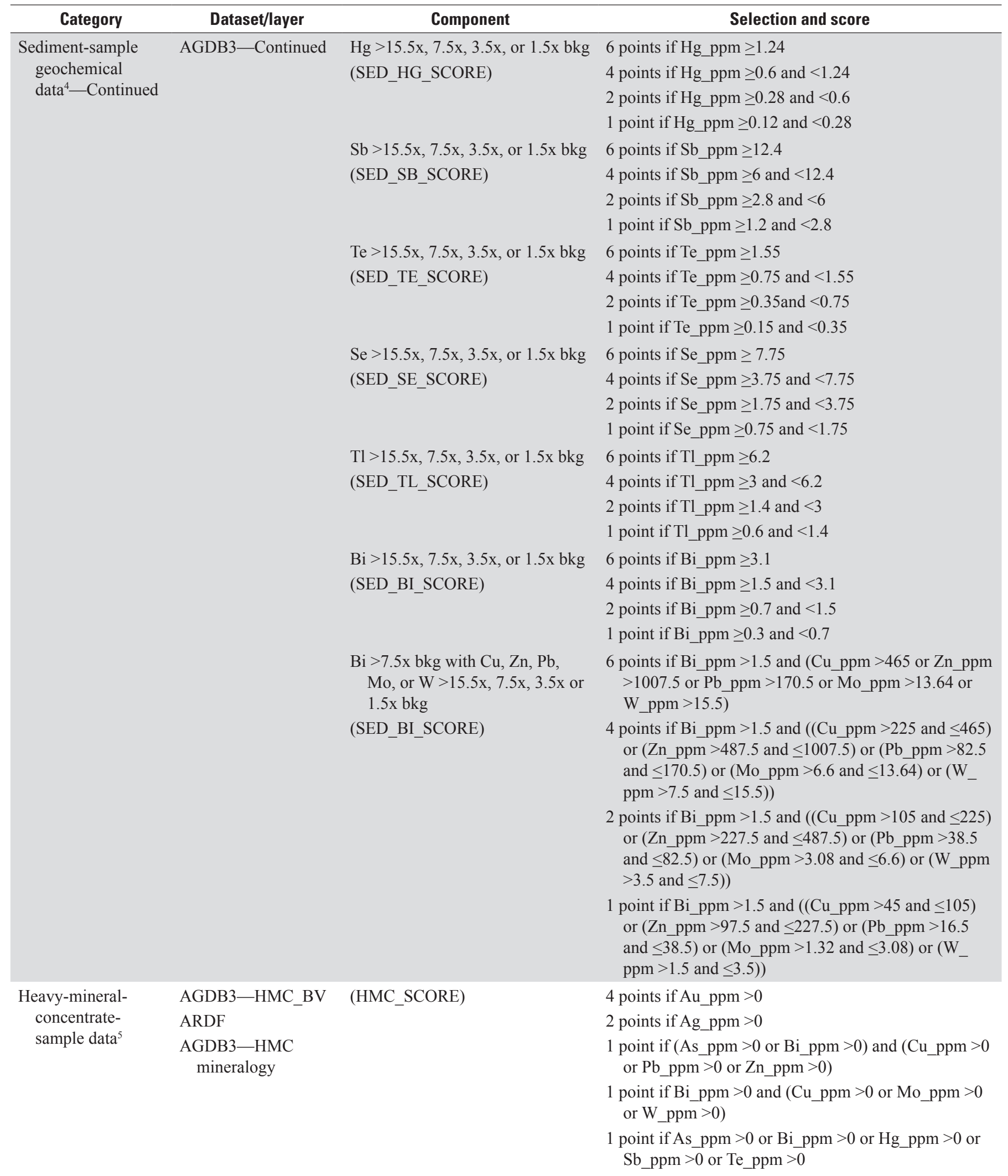


Table 2. Scoring template for analysis of undivided lode gold potential within each hydrologic unit code (HUC) in Alaska.-Continued

\begin{tabular}{|c|c|c|c|}
\hline Category & Dataset/layer & Component & Selection and score \\
\hline $\begin{array}{l}\text { Heavy-mineral- } \\
\text { concentrate- } \\
\text { sample data }{ }^{5}- \\
\text { Continued }\end{array}$ & $\begin{array}{l}\text { AGDB3-HMC_BV } \\
\text { ARDF } \\
\text { AGDB3-HMC } \\
\quad \text { mineralogy } \\
\text { - Continued }\end{array}$ & (MIN_SCORE) & $\begin{array}{l}4 \text { points if GENERIC_MODEL in ARDF is "Placer } \\
\text { deposits (Garnett and Bassett, 2005)" and not DE- } \\
\text { POSIT_MODEL_NUMBER such as "39E" } \\
3 \text { points if gold is present } \\
2 \text { points if (arsenopyrite, cinnabar, or stibnite is } \\
\text { present) or (OreRelatedMnrl_Comment contains } \\
\text { pyrite/arsenopyrite or bismuth or bismuth oxides or } \\
\text { boulangerite or enargite or jamesonite or orpiment or } \\
\text { proustite or realgar or silver sulfosalts or stibnite or } \\
\text { tetrahedrite) } \\
1 \text { point if (chalcopyrite or galena or molybdenite or } \\
\text { powellite or scheelite or sphalerite is present) or } \\
\text { (OreRelatedMnrl_Comment contains anglesite or } \\
\text { cerussite or copper sulfide/copper oxide or galena/ } \\
\text { cerrusite or marcasite or wolframite or wulfenite or } \\
\text { scheelite) }\end{array}$ \\
\hline
\end{tabular}

${ }^{1}$ Lithology scores are additive, for a possible total score of 24 for each HUC.

${ }^{2}$ See appendix 2 for a list of lode gold model keywords and the scoring template for ARDF records; the maximum single score for a HUC contributes to the total score from all seven databases.

${ }^{3}$ Rock geochemical scores are additive, for a possible total score of 66 for each HUC.

${ }^{4}$ Sediment geochemical scores are additive, for a possible total score of 71 for each HUC.

${ }^{5}$ Heavy mineral concentrate scores are additive, for a possible total score of 19 for each HUC.

Table 3. Mineral resource potential versus certainty classification matrix for undivided lode gold deposits in Alaska.

[c, certainty; HUC, hydrologic unit code; p, potential]

\begin{tabular}{|c|c|c|c|c|c|}
\hline \multirow{2}{*}{ Undivided lode gold } & \multicolumn{3}{|c|}{ Estimated certainty ${ }^{1}$} & & \\
\hline & Low & Medium & High & & \\
\hline \multirow{3}{*}{$\begin{array}{l}\text { Unknown (Total score }=0 \text { and } \\
\text { no sediment samples in HUC } \\
\text { or aerial magnetic survey is } \\
\text { only dataset represented and } \\
\text { no sediment samples in HUC) }\end{array}$} & 1-2 datasets not null (c) & 3-4 datasets not null (c) & 5 datasets not null (c) & 可 & \multirow{3}{*}{ 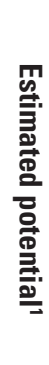 } \\
\hline & Total score $20-57(p)$ & Total score $20-57(\mathrm{p})$ & Total score $20-57(\mathrm{p})$ & 3 & \\
\hline & $\begin{array}{l}\text { Total score } 0-19(p) \\
1-2 \text { datasets not null (c) }\end{array}$ & $\begin{array}{l}\text { Total score } 0-19(p) \\
3-4 \text { datasets not null (c) }\end{array}$ & $\begin{array}{l}\text { Total score } 0-19(\mathrm{p}) \\
5 \text { datasets not null or total } \\
\text { score }=0 \text { (c) }\end{array}$ & Г్ & \\
\hline
\end{tabular}

${ }^{1}$ Abbreviations (p) and (c) in cells denote which components contribute to assignment of potential and certainty, respectively. 
Table 4. Scoring template for analysis of potential for orogenic gold deposits within each hydrologic unit code (HUC) in Alaska.

[AGDB3, Alaska Geochemical Database, version 3.0; ARDF, Alaska Resource Data File; bkg, background concentration (see appendix 1); HMC, heavy mineral concentrate; ppm, parts per million; Ag, silver; As, arsenic; $\mathrm{Au}$, gold; $\mathrm{Bi}$, bismuth; $\mathrm{Cu}$, copper; $\mathrm{Hg}$, mercury; $\mathrm{Pb}$, lead; Te, tellurium; W, tungsten; $\mathrm{Zn}$, zinc]

\begin{tabular}{|c|c|c|}
\hline Category & Dataset/layer & Component \\
\hline Lithology ${ }^{1}$ & $\begin{array}{l}\text { Geologic map of } \\
\text { Alaska (Wilson } \\
\text { and others, 2015) }\end{array}$ & $\begin{array}{l}\text { (LITHOLOGY } \\
\text { SCORE) }\end{array}$ \\
\hline ARDF records ${ }^{2}$ & ARDF & $\begin{array}{l}\text { Lode gold orogenic } \\
\text { model keywords } \\
\text { (ARDF_SCORE) }\end{array}$ \\
\hline $\begin{array}{l}\text { Rock geochemical } \\
\text { data }^{3}\end{array}$ & AGDB3 & $\begin{array}{l}\mathrm{Au}>7.5 \mathrm{x} \text { or } 1.5 \mathrm{x} \text { bkg } \\
\text { (RCK_AU_SCORE) } \\
\mathrm{Ag}>1.5 \mathrm{x} \text { bkg } \\
\text { (RCK_SCORE) } \\
\text { As or Te or Bi }>7.5 \mathrm{x} \\
\quad \text { bkg } \\
\text { (RCK_SCORE) } \\
\text { As or Te or Bi or W } \\
>3.5 \mathrm{x} \text { bkg } \\
\text { (RCK_SCORE) } \\
\text { As }>7.5 \mathrm{x} \text { bkg with } \\
\text { Cu, Pb or Zn } \\
>15.5 \mathrm{x}, 7.5 \mathrm{x}, 3.5 \mathrm{x} \text {, } \\
\text { or } 1.5 \mathrm{x} \text { bkg } \\
\text { (RCK_AS_SCORE) }\end{array}$ \\
\hline
\end{tabular}

2 points if (As_ppm $>5.95$ and $<12.75$ ) or $\left(\right.$ Te $\_p p m>0.0175$ and $\left.<0.0375\right)$ or $\left(\right.$ Bi $\_p p m>0.2975$ and $<0.6375$ ) or $\mathrm{W} \_$ppm $>3.5$

4 points if $\mathrm{As}$ pppm $\geq 12.75$ and $\left(\mathrm{Cu} \_\right.$ppm $>387.5$ or $\mathrm{Pb} \_$ppm $>229.4$ or $\mathrm{Zn} \mathrm{ppm}>1007.5)$ and $\operatorname{not}(\mathrm{Cu}$ ppm $>387.5$ and $\mathrm{Pb}$ ppm $>229.4$ and $\mathrm{Zn \_ ppm}>1007.5$ )

3 points if As_ppm $\geq 12.75$ and $\left(\left(\mathrm{Cu} \_\right.\right.$ppm $>187.5$ and $\left.\leq 387.5\right)$ or $\left(\mathrm{Pb} \_\right.$ppm $>111$ and $\left.\leq 229.4\right)$ or $\left(\mathrm{Zn} \_\right.$ppm $>487.5$ and $\left.\left.\leq 1007.5\right)\right)$ and not $\left(\left(\mathrm{Cu} \_\right.\right.$ppm $>187.5$ and $\left.\leq 387.5\right)$ and $\left(\mathrm{Pb} \_\right.$ppm $>111$ and $\left.\leq 229.4\right)$ and $\left(\mathrm{Zn} \_\right.$ppm $>487.5$ and $\left.\left.\leq 1007.5\right)\right)$

2 points if As_ppm $\geq 12.75$ and $\left(\left(\mathrm{Cu} \_\right.\right.$ppm $>87.5$ and $\left.\leq 187.5\right)$ or $\left(\mathrm{Pb} \_\right.$ppm $>51.8$ and $\leq 111)$ or $\left(\mathrm{Zn} \_\right.$ppm $>227.5$ and $\left.\left.\leq 487.5\right)\right)$ and not $\left(\left(\mathrm{Cu} \_\right.\right.$ppm $>87.5$ and $\leq 187.5)$ and $\left(\mathrm{Pb} \_\right.$ppm $>51.8$ and $\left.\leq 111\right)$ and $\left(\mathrm{Zn} \_\right.$ppm $>227.5$ and $\leq 487.5)$ )

1 point if As_ppm $\geq 12.75$ and $\left(\left(\mathrm{Cu} \_\right.\right.$ppm $>37.5$ and $\left.\leq 87.5\right)$ or $\left(\mathrm{Pb} \_\right.$ppm $>22.2$ and $\leq 51.8)$ or $\left(\mathrm{Zn} \_\right.$ppm $>97.5$ and $\left.\left.\leq 227.5\right)\right)$ and not $\left(\left(\mathrm{Cu} \_\right.\right.$ppm $>37.5$ and $\leq 87.5)$ and $\left(\mathrm{Pb} \_\right.$ppm $>22.2$ and $\left.\leq 51.8\right)$ and $\left(\mathrm{Zn} \_\right.$ppm $>97.5$ and $\leq 227.5)$ )

$\mathrm{Bi}>7.5 \mathrm{x}$ bkg with $\mathrm{Cu}, \quad 4$ points if $\mathrm{Bi} \_$ppm $\geq 0.6375$ and $\left(\mathrm{Cu} \_\right.$ppm $>387.5$ or $\mathrm{Pb} \_$ppm $>229.4$ or $\mathrm{Pb}$, or $\mathrm{Zn}>15.5 \mathrm{x}, \quad \mathrm{Zn} \_$ppm $\left.>1007.5\right)$ and $\operatorname{not}\left(\mathrm{Cu} \_\right.$ppm $>0.387 .5$ and $\mathrm{Pb} \_$ppm $>229.4$ and 7.5x, 3.5x, or $1.5 \mathrm{x} \quad \mathrm{Zn} \_$ppm $>1007.5$ ) bkg (RCK_BI_SCORE)

3 points if $\mathrm{Bi} \_$ppm $\geq 0.6375$ and $\left(\left(\mathrm{Cu} \_\right.\right.$ppm $>187.5$ and $\left.\leq 387.5\right)$ or $\left(\mathrm{Pb} \_\right.$ppm $>111$ and $\left.\leq 229.4\right)$ or $\left(\mathrm{Zn} \_\right.$ppm $>487.5$ and $\left.\left.\leq 1007.5\right)\right)$ and not $\left(\left(\mathrm{Cu} \_\right.\right.$ppm $>187.5$ and $\left.\leq 387.5\right)$ and $\left(\mathrm{Pb} \_\right.$ppm $>111$ and $\left.\leq 229.4\right)$ and $\left(\mathrm{Zn} \_\right.$ppm $>487.5$ and $\left.\left.\leq 1007.5\right)\right)$

2 points if $\mathrm{Bi} \_p p m \geq 0.6375$ and $\left((\mathrm{Cu}\right.$ ppm $>87.5$ and $\leq 187.5)$ or $\left(\mathrm{Pb} \_\right.$ppm $>51.8$ and $\leq 111)$ or $\left(\mathrm{Zn} \_\right.$ppm $>227.5$ and $\left.\left.\leq 487.5\right)\right)$ and not $\left(\left(\mathrm{Cu} \_\right.\right.$ppm $>87.5$ and $\leq 187.5)$ and $\left(\mathrm{Pb} \_\right.$ppm $>51.8$ and $\left.\leq 111\right)$ and $\left(\mathrm{Zn} \_\right.$ppm $>227.5$ and $\leq 487.5)$ )

1 point if $\mathrm{Bi} \_$ppm $\geq 0.6375$ and $\left(\left(\mathrm{Cu} \_\right.\right.$ppm $>37.5$ and $\left.\leq 87.5\right)$ or $\left(\mathrm{Pb} \_\right.$ppm $>22.2$ and $\leq 51.8)$ or $\left(\mathrm{Zn} \_\right.$ppm $>97.5$ and $\left.\left.\leq 227.5\right)\right)$ and not $\left(\left(\mathrm{Cu} \_\right.\right.$ppm $>37.5$ and $\leq 87.5)$ and $\left(\mathrm{Pb} \_\right.$ppm $>22.2$ and $\left.\leq 51.8\right)$ and $\left(\mathrm{Zn} \_\right.$ppm $>97.5$ and $\leq 227.5)$ ) 
Table 4. Scoring template for analysis of potential for orogenic gold deposits within each hydrologic unit code (HUC) in Alaska.-Continued

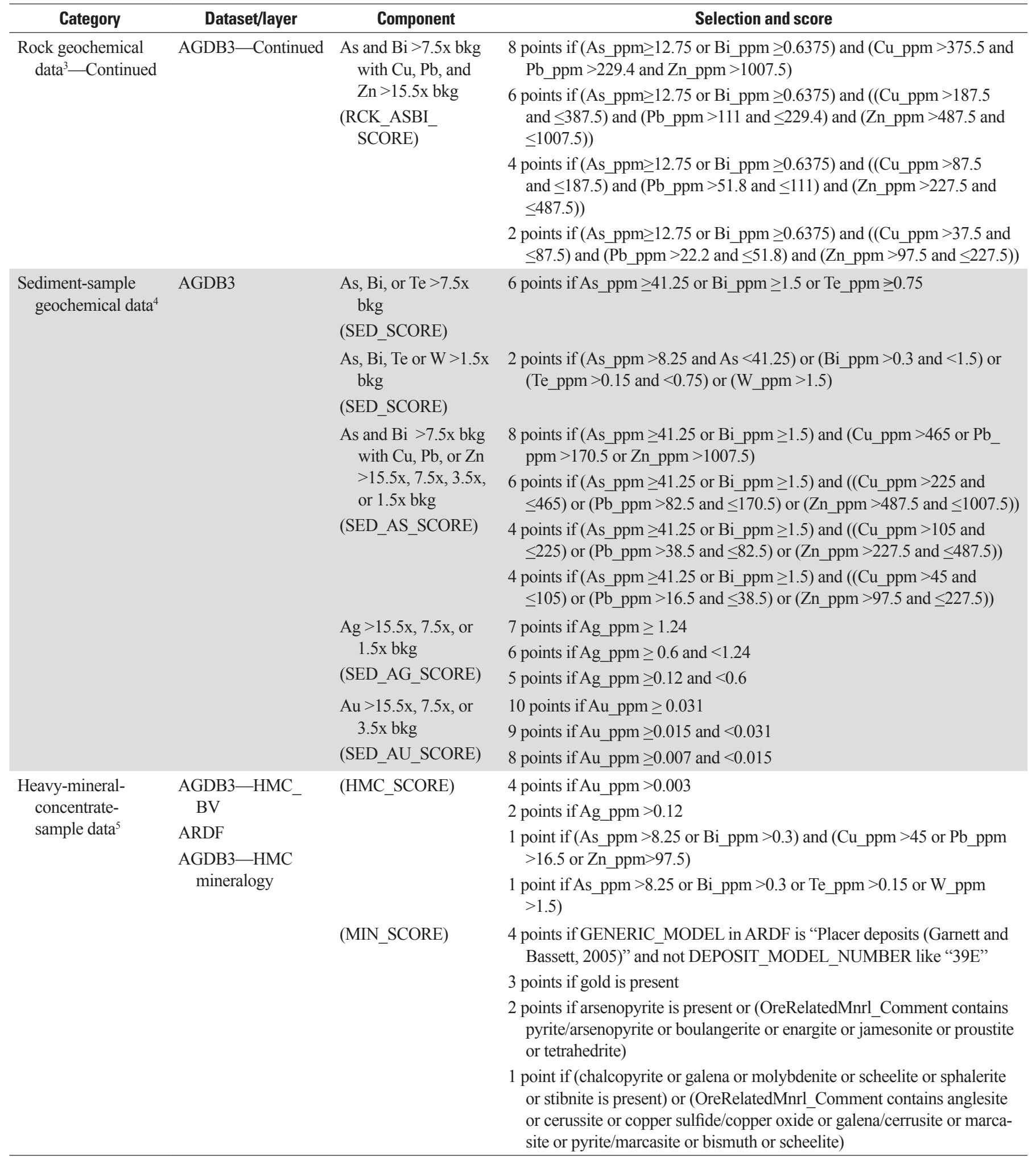

${ }^{1}$ Lithology scores are additive, for a possible total score of 10 for each HUC.

${ }^{2}$ See appendix 2 for a list of lode gold model keywords and the scoring template for ARDF records; maximum single score for a HUC contributes to the total score.

${ }^{3}$ Rock geochemical scores are additive, for a possible total score of 33 for each HUC.

${ }^{4}$ Sediment geochemical scores are additive, for a possible total score of 33 for each HUC.

${ }^{5}$ Heavy mineral concentrate scores are additive, for a possible total score of 18 for each HUC. 
Table 5. Mineral resource potential versus certainty classification matrix for orogenic gold deposits in Alaska.

[c, certainty; HUC, hydrologic unit code; p, potential]

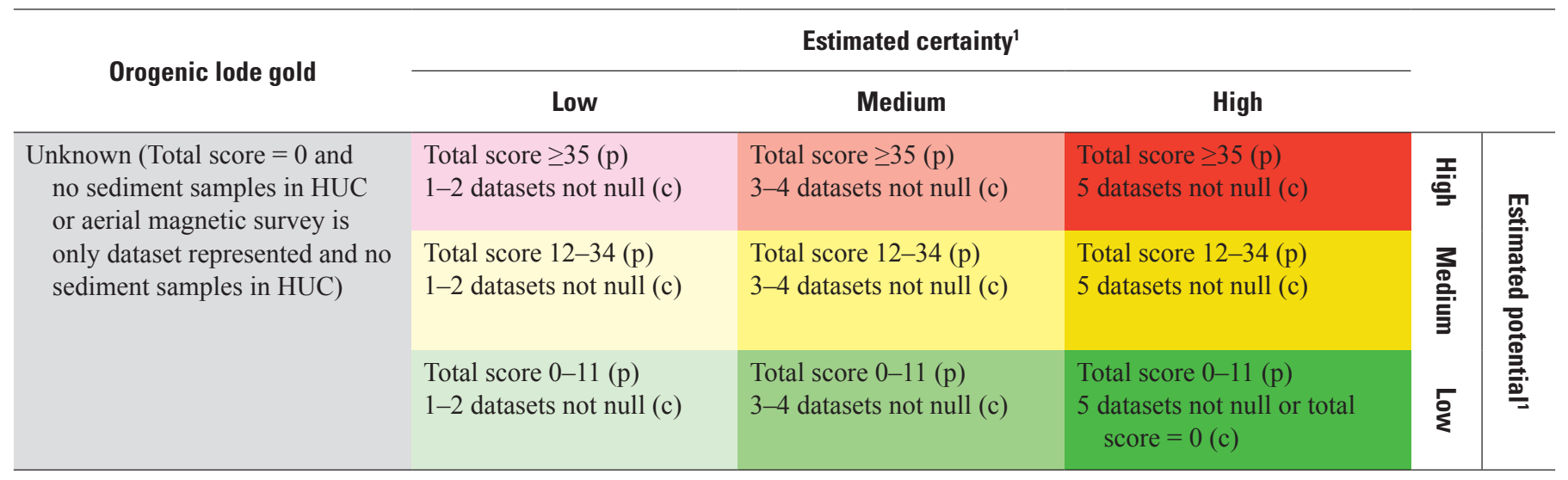

${ }^{1}$ Abbreviations (p) and (c) in cells denote which components contribute to assignment of potential and certainty, respectively.

Table 6. Scoring template for analysis of potential for intrusion-related gold deposits within each hydrologic unit code (HUC) in Alaska.

[AGDB3, Alaska Geochemical Database, version 3.0; ARDF, Alaska Resource Data File; bkg, background concentration (see appendix 1); HMC, heavy mineral concentrate; ppm, parts per million; As, arsenic; $\mathrm{Au}$, gold; $\mathrm{Bi}$, bismuth; $\mathrm{Cu}$, copper; Mo, molybdenum; $\mathrm{Sb}$, antimony; Te, tellurium; $\mathrm{W}$, tungsten]

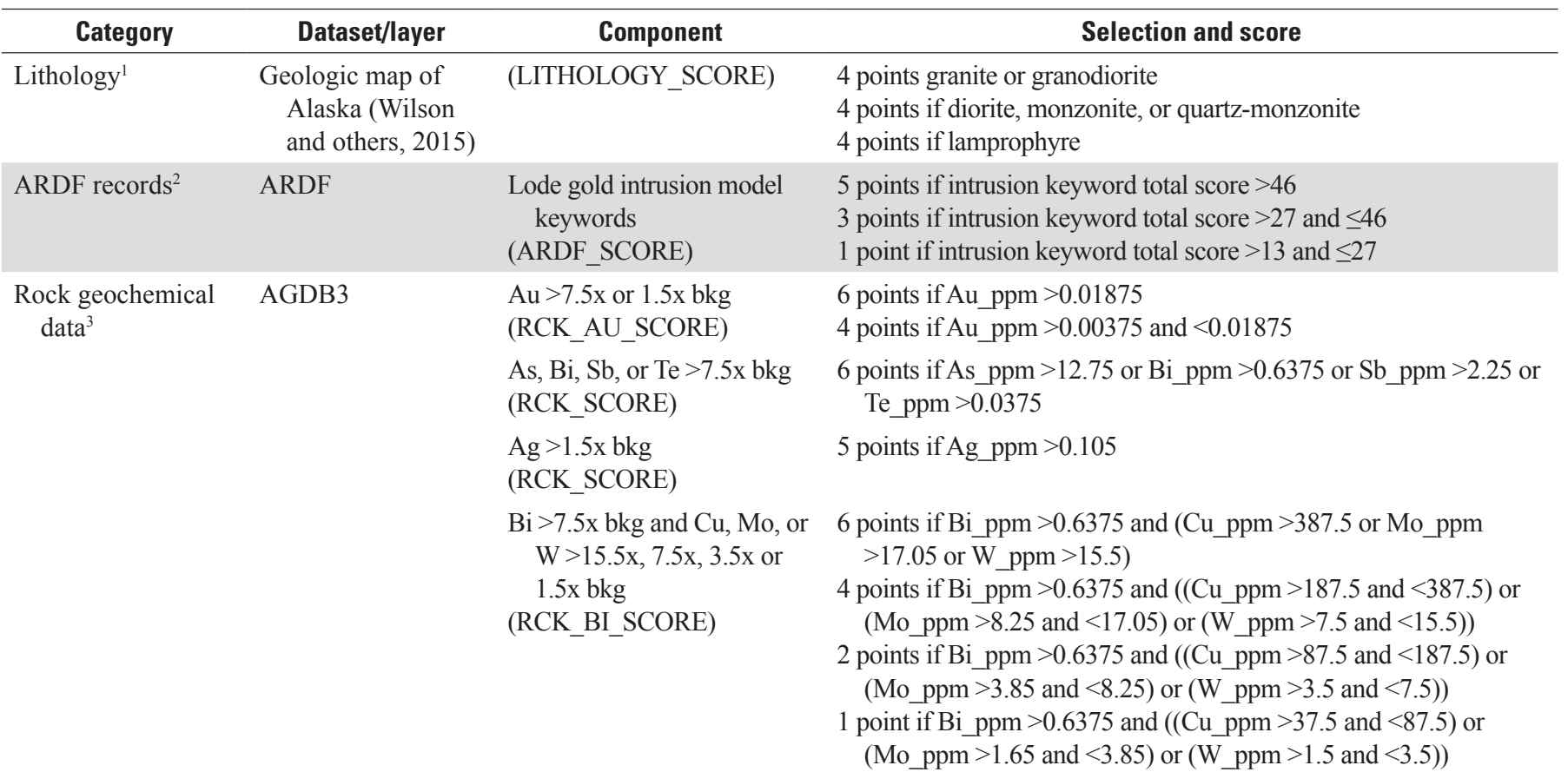


Table 6. Scoring template for analysis of potential for intrusion-related gold deposits within each hydrologic unit code (HUC) in Alaska.-Continued

\begin{tabular}{|c|c|c|c|}
\hline Category & Dataset/layer & Component & Selection and score \\
\hline \multirow[t]{3}{*}{$\begin{array}{l}\text { Sediment-sample } \\
\text { geochemical } \\
\text { data }^{4}\end{array}$} & AGDB3 & $\begin{array}{l}\text { Au } 15.5 x, 7.5 x \text {, or } 1.5 x \text { bkg } \\
\text { (SED_AU_SCORE) }\end{array}$ & $\begin{array}{l}10 \text { points if } \mathrm{Au} \_ \text {ppm }>0.031 \\
9 \text { points if } \mathrm{Au} \_ \text {ppm }>0.015 \text { and }<0.031 \\
8 \text { points if } \mathrm{Au} \_ \text {ppm }>0.003 \text { and }<0.015\end{array}$ \\
\hline & & $\begin{array}{l}\text { Ag } 15.5 x, 7.5 x \text {, or } 1.5 x \text { bkg } \\
\text { (SED_AG_SCORE) }\end{array}$ & $\begin{array}{l}7 \text { points if Ag_ppm }>1.24 \\
6 \text { points if } \mathrm{Ag} \_ \text {_ppm }>0.6 \text { and }<1.24 \\
5 \text { points if Ag_ppm }>0.12 \text { and }<0.6\end{array}$ \\
\hline & & $\begin{array}{l}\mathrm{Bi}>7.5 \mathrm{x} \text { bkg and } \mathrm{Cu}, \mathrm{Mo} \text {, or } \\
\quad \mathrm{W}>15.5 \mathrm{x}, 7.5 \mathrm{x}, 3.5 \mathrm{x} \text {, or } \\
1.5 \mathrm{x} \text { bkg } \\
\text { (SED_BI_SCORE) }\end{array}$ & $\begin{array}{l}6 \text { points if } \mathrm{Bi} \_ \text {ppm }>1.5 \text { and }\left(\mathrm{Cu} \_ \text {ppm }>465 \text { or } \mathrm{Mo} \_ \text {ppm }>13.64\right. \\
\left.\text { or } \mathrm{W} \_ \text {ppm }>15.5\right) \\
4 \text { points if } \mathrm{Bi} \_ \text {ppm }>1.5 \text { and }\left(\left(\mathrm{Cu} \_ \text {ppm }>225 \text { and }<465\right) \text { or }\left(\mathrm{Mo} \_\right.\right. \\
\left.\text {ppm }>6.6 \text { and }<13.64) \text { or }\left(\mathrm{W} \_ \text {ppm }>7.5 \text { and }<15.5\right)\right) \\
2 \text { points if } \mathrm{Bi} \_ \text {ppm }>1.5 \text { and }\left(\left(\mathrm{Cu} \_ \text {ppm }>105 \text { and }<225\right) \text { or }\left(\mathrm{Mo} \_\right.\right. \\
\left.\text {ppm }>3.08 \text { and }<6.6) \text { or }\left(\mathrm{W} \_ \text {ppm }>3.5 \text { and }<7.5\right)\right) \\
1 \text { point if } \mathrm{Bi} \_ \text {ppm }>1.5 \text { and }\left(\left(\mathrm{Cu} \_ \text {ppm }>45 \text { and }<105\right) \text { or }\left(\mathrm{Mo} \_ \text {ppm }\right.\right. \\
\left.>1.32 \text { and }<3.08) \text { or }\left(\mathrm{W} \_ \text {ppm }>1.5 \text { and }<3.5\right)\right)\end{array}$ \\
\hline \multirow[t]{2}{*}{$\begin{array}{l}\text { Heavy-mineral-con- } \\
\text { centrate-sample } \\
\text { data }^{5}\end{array}$} & $\begin{array}{l}\text { AGDB3- HMC_BV } \\
\text { ARDF } \\
\text { AGDB3-HMC } \\
\text { mineralogy }\end{array}$ & (HMC_SCORE) & $\begin{array}{l}4 \text { points if } \mathrm{Au} \_ \text {ppm }>0.003 \\
2 \text { points if } \mathrm{Ag} \_ \text {ppm }>0.12 \\
2 \text { points if } \mathrm{Bi} \_ \text {ppm }>0.3 \text { and }\left(\mathrm{Cu} \_ \text {ppm }>45 \text { or } \mathrm{Mo} \_ \text {ppm }>1.32 \text { or }\right. \\
\left.\mathrm{W} \_ \text {_ppm }>1.5\right) \\
1 \text { point if } \mathrm{As} \_ \text {ppm }>8.25 \text { or } \mathrm{Bi} \_ \text {ppm }>0.3 \text { or } \mathrm{Sb} \_ \text {ppm }>1.2 \text { or } \\
\text { Te_ppm }>0.15\end{array}$ \\
\hline & & (MIN_SCORE) & $\begin{array}{l}4 \text { points if GENERIC_MODEL in ARDF is Placer deposits (Gar- } \\
\text { nett and Bassett, 2005) and not DEPOSIT_MODEL_NUMBER } \\
\text { like 39E } \\
3 \text { points if gold is present } \\
2 \text { points if arsenopyrite or stibnite is present or (OreRelatedM- } \\
\text { nrl_Comment contains pyrite/arsenopyrite or bismuth or bismuth } \\
\text { oxides or boulangerite or enargite or jamesonite or proustite or } \\
\text { silver sulfosalts or stibnite or tetrahedrite) } \\
1 \text { point if (chalcopyrite or galena or molybdenite or powellite or } \\
\text { scheelite or sphalerite is present) or (OreRelatedMnrl_Comment } \\
\text { contains anglesite or cerussite or copper sulfide/copper oxide or } \\
\text { galena/cerrusite or marcasite or wolframite or wulfenite) }\end{array}$ \\
\hline Aeromagnetic data ${ }^{6}$ & $\begin{array}{l}\text { Aerial magnetic } \\
\text { survey data } \\
\text { Geologic map of } \\
\text { Alaska } \\
\text { (Wilson and others, } \\
\text { 2015) }\end{array}$ & (AEROMAG_SCORE) & $\begin{array}{l}3 \text { points if filtered data yields a negative value for a cell within a } \\
\text { HUC }\end{array}$ \\
\hline
\end{tabular}

${ }^{1}$ Lithology scores are additive, for a possible total score of 12 for each HUC.

${ }^{2}$ See appendix 2 for a list of lode gold model keywords and the scoring template for ARDF records; maximum single score for an HUC contributes to the total score.

${ }^{3}$ Rock geochemical scores are additive, for a possible total score of 23 for each HUC.

${ }^{4}$ Sediment geochemical scores are additive, for a possible total score of 27 for each HUC.

${ }^{5}$ Heavy mineral concentrate scores are additive, for a possible total score of 19 for each HUC.

${ }^{6}$ Aeromagnetic data reduced to the north pole, with upward continuation transform applied and tilt-derivative applied. Only HUCs containing cells that spatially overlap granitoid and hypabyssal rocks were scored. Maximum possible score is 3 points for each HUC. 
Table 7. Mineral resource potential versus certainty classification matrix for intrusion-related lode gold deposits in Alaska.

[c, certainty; HUC, hydrologic unit code; p, potential]

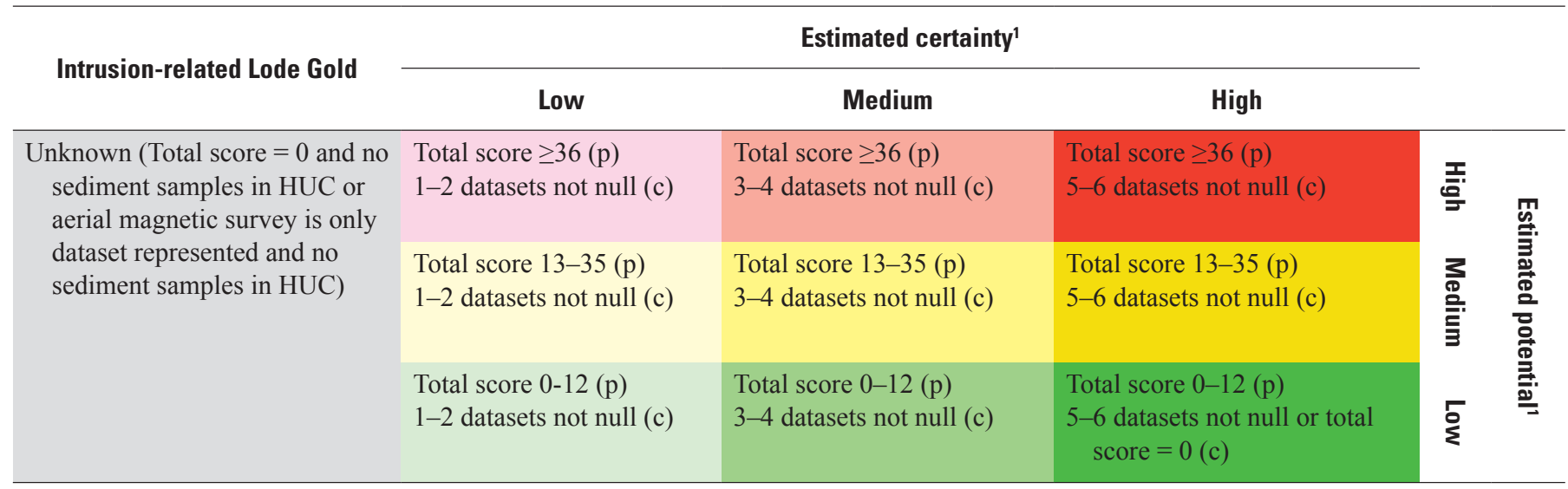

${ }^{1}$ Abbreviations (p) and (c) in cells denote which components contribute to assignment of potential and certainty, respectively.

Table 8. Scoring template for analysis of potential for epithermal gold deposits within each hydrologic unit code (HUC) in Alaska.

[AGDB3, Alaska Geochemical Database, version 3.0; ARDF, Alaska Resource Data File; bkg, background concentration (see appendix 1); HMC, heavy mineral concentrate; ppm, parts per million; Ag, silver; As, arsenic; Au, gold; $\mathrm{Bi}$, bismuth; $\mathrm{Cu}$, copper; $\mathrm{Hg}$, mercury; Pb, lead; $\mathrm{Sb}$, antimony; Te, tellurium; Tl, thallium; Zn, zinc]

\begin{tabular}{|c|c|c|c|}
\hline Category & Dataset/layer & Component & Selection and score \\
\hline Lithology $^{1}$ & $\begin{array}{l}\text { Geologic map of } \\
\text { Alaska (Wilson } \\
\text { and others, 2015) }\end{array}$ & (LITHOLOGY_SCORE) & $\begin{array}{l}5 \text { points if felsic-hypabyssal or hypabyssal-basalt } \\
5 \text { points if andesite or hypabyssal andesite } \\
3 \text { points if granite or granodiorite } \\
3 \text { points if diorite, monzonite, or quartz-monzonite }\end{array}$ \\
\hline ARDF records ${ }^{2}$ & ARDF & $\begin{array}{l}\text { Lode gold epithermal model } \\
\text { keywords }\end{array}$ & $\begin{array}{l}5 \text { points if epithermal keyword total score }>47 \\
3 \text { points if epithermal keyword total score }>29 \text { and } \leq 47 \\
1 \text { point if epithermal keyword total score }>15 \text { and } \leq 29\end{array}$ \\
\hline \multirow[t]{3}{*}{$\begin{array}{l}\text { Rock geochemical } \\
\text { data }^{3}\end{array}$} & AGDB3 & $\begin{array}{l}\mathrm{Au}>7.5 \mathrm{x} \text { or } 1.5 \mathrm{x} \text { bkg } \\
\left(\mathrm{RCK} \_\mathrm{AU} \_\mathrm{SCORE}\right) \\
\mathrm{Hg} \text { or } \mathrm{Te}>7.5 \mathrm{x} \text { bkg } \\
\left(\mathrm{RCK} \_\mathrm{SCORE}\right)\end{array}$ & $\begin{array}{l}6 \text { points if } \mathrm{Au} \_ \text {ppm }>0.01875 \\
4 \text { points if } \mathrm{Au} \_ \text {ppm }>0.00375 \text { and } \leq 0.01875 \\
8 \text { points if } \mathrm{Hg} \_ \text {ppm } \geq 0.3 \text { or } \mathrm{Te} \_ \text {ppm } \geq 0.0375\end{array}$ \\
\hline & & $\begin{array}{l}\mathrm{As}, \mathrm{Bi} \text {, or } \mathrm{Sb}>7.5 \mathrm{x} \text { bkg } \\
(\mathrm{RCK} \text { SCORE) }\end{array}$ & $\begin{array}{l}6 \text { points if As_ppm } \geq 12.75 \text { or } \mathrm{Bi} \_ \text {ppm } \geq 0.6375 \text { or } \mathrm{Sb} \_ \text {ppm } \\
\geq 2.25\end{array}$ \\
\hline & & $\begin{array}{l}\mathrm{Tl}>7.5 \mathrm{x} \text { bkg } \\
(\mathrm{RCK} \text { SCORE) }\end{array}$ & 4 points if $\mathrm{Tl} \_$ppm $\geq 3.9$ \\
\hline
\end{tabular}


Table 8. Scoring template for analysis of potential for epithermal gold deposits within each hydrologic unit code (HUC) in Alaska.-Continued

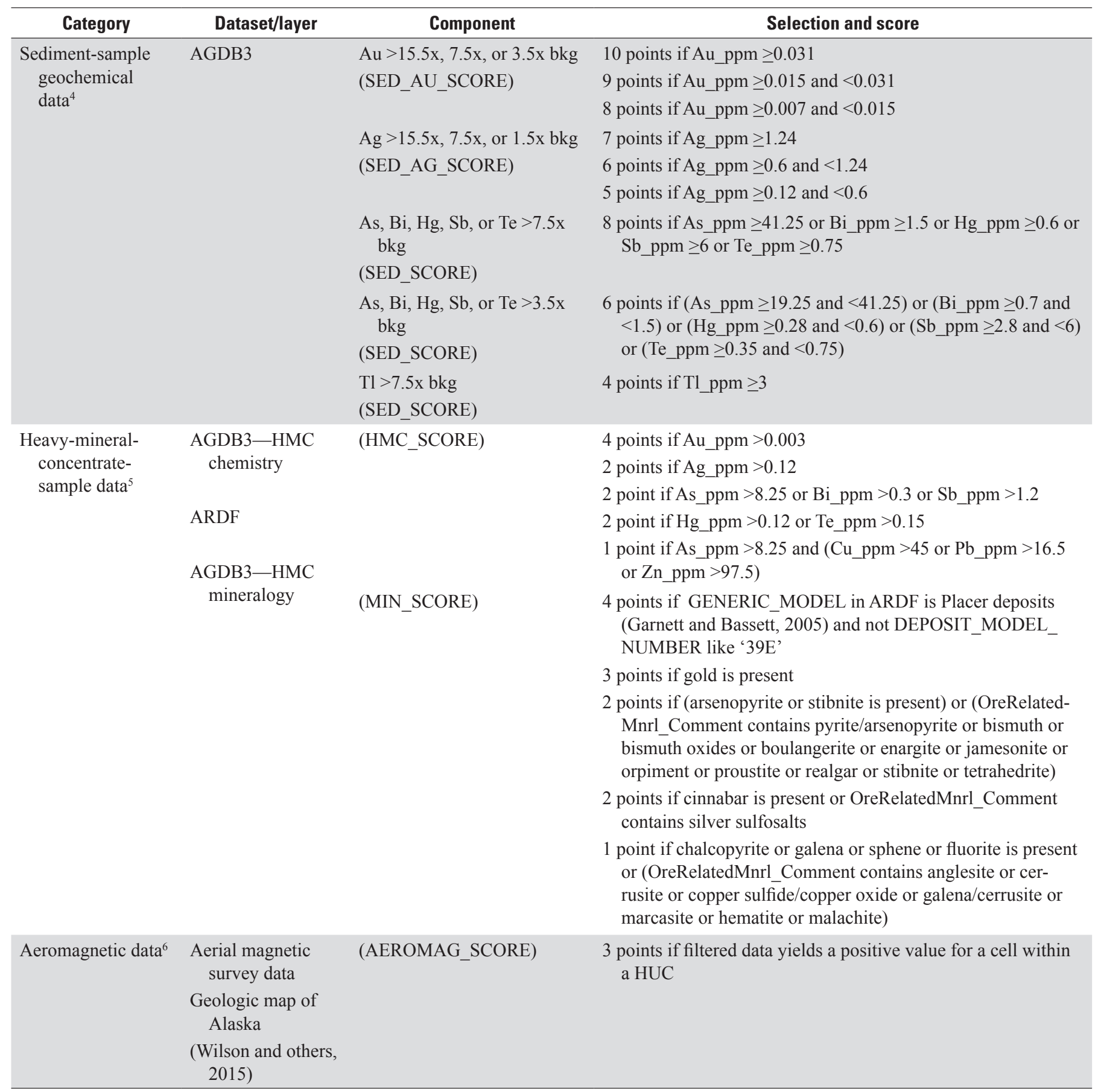

${ }^{1}$ Lithology scores are additive, for a possible total score of 16 for each HUC.

${ }^{2}$ See appendix 2 for a list of lode gold model keywords and the scoring template for ARDF records; maximum single score for an HUC contributes to the total score.

${ }^{3}$ Rock geochemical scores are additive, for a possible total score of 29 for each HUC.

${ }^{4}$ Sediment geochemical scores are additive, for a possible total score of 35 for each HUC.

${ }^{5}$ Heavy mineral concentrate scores are additive, for a possible total score of 23 for each HUC.

${ }^{6}$ Aeromagnetic data reduced to the north pole, with upward continuation transform applied and tilt-derivative applied. Only HUCs containing cells that spatially overlap granitoid and hypabyssal rocks were scored. Maximum possible score is 3 points for each HUC. 
Table 9. Mineral resource potential versus certainty classification matrix for epithermal gold deposits in Alaska.

[c, certainty; HUC, hydrologic unit code; p, potential]

\begin{tabular}{|c|c|c|c|c|c|}
\hline \multirow{2}{*}{ Epithermal gold } & \multicolumn{3}{|c|}{ Estimated certainty ${ }^{1}$} & & \\
\hline & Low & Medium & High & & \\
\hline \multirow[t]{3}{*}{$\begin{array}{l}\text { Unknown (Total score }=0 \text { and no } \\
\text { sediment samples in HUC }\end{array}$} & $\begin{array}{l}\text { Total score } \geq 42(p) \\
1-2 \text { datasets not null (c) }\end{array}$ & $\begin{array}{l}\text { Total score } \geq 42(p) \\
3-4 \text { datasets not null (c) }\end{array}$ & $\begin{array}{l}\text { Total score } \geq 42(p) \\
5-6 \text { datasets not null (c) }\end{array}$ & 돌 & \\
\hline & $\begin{array}{l}\text { Total score } 16-41(\mathrm{p}) \\
1-2 \text { datasets not null (c) }\end{array}$ & $\begin{array}{l}\text { Total score } 16-41(p) \\
3-4 \text { datasets not null (c) }\end{array}$ & $\begin{array}{l}\text { Total score } 16-41(\mathrm{p}) \\
5-6 \text { datasets not null (c) }\end{array}$ & 3 & 淮 \\
\hline & $\begin{array}{l}\text { Total score } 0-15(\mathrm{p}) \\
1-2 \text { datasets not null (c) }\end{array}$ & $\begin{array}{l}\text { Total score } 0-15(\mathrm{p}) \\
3-4 \text { datasets not null (c) }\end{array}$ & $\begin{array}{l}\text { Total score } 0-15(\mathrm{p}) \\
5-6 \text { datasets not null or total } \\
\text { score }=0 \text { (c) }\end{array}$ & ¿ & $\underline{=}$ \\
\hline
\end{tabular}

${ }^{1}$ Abbreviations (p) and (c) in cells denote which components contribute to assignment of potential and certainty, respectively.

Table 10. Scoring template for analysis of potential for porphyry and epithermal gold deposits within each hydrologic unit code (HUC) in Alaska.

[AGDB3, Alaska Geochemical Database, version 3.0; ARDF, Alaska Resource Data File; bkg, background concentration (see appendix 1); HMC, heavy mineral concentrate; ppm, parts per million; As, arsenic; Au, gold; Bi, bismuth; $\mathrm{Cu}$, copper; Hg, mercury; Mo, molybdenum; Sb, antimony; Se, selenium; Te, tellurium; W, tungsten]

\begin{tabular}{llll}
\hline \multicolumn{1}{c}{ Category } & \multicolumn{1}{c}{ Dataset/layer } & \multicolumn{1}{c}{ Component } & \multicolumn{1}{c}{ Selection and score } \\
\hline Lithology $^{1}$ & $\begin{array}{c}\text { Geologic map of } \\
\text { Alaska (Wilson } \\
\text { and others, 2015) }\end{array}$ & (LITHOLOGY_SCORE) & 3 points if felsic-hypabyssal or hypabyssal-basalt \\
& & & 3 points if andesite or hypabyssal andesite \\
& & 3 points if granite or granodiorite \\
ARDF records ${ }^{2}$ & ARDF & Lode gold copper model & 5 points if diorite, monzonite, or quartz-monzonite \\
& & keywords & 3 points if Au copper keyword total score $>12$ and $\leq 28$
\end{tabular}

Rock geochemical AGDB3 data $^{3}$
$\mathrm{W}<3.5 \mathrm{x}$ bkg and As, Sb, $\mathrm{Hg}$, Se, or Te $>15.5 \mathrm{x}$, $7.5 \mathrm{x}, 3.5 \mathrm{x}$, or $1.5 \mathrm{x}$ bkg (RCK_W_SCORE)
4 points if $\mathrm{W} \_$ppm $<3.5$ and ( $\left(\right.$ As_ppm $>26.35$ or $\mathrm{Sb} \_$ppm $>4.65$ or $\mathrm{Hg} \_$ppm $>0.62$ or Se_ppm $>1.86$ or Te_ppm $>0.0775$ ) and not (As_ppm $>26.35$ and $\mathrm{Sb} \_$ppm $>4.65$ and $\mathrm{Hg} \_$ppm $>0.62$ ) and not (As_ppm $>12.75$ and $\mathrm{Sb} \_p p m>2.25$ and $\mathrm{Hg} \_$ppm $>0.3$ and $(\mathrm{Se}$ ppm $>0.9$ or Te $\left.\_p m>0.0375\right)$ )

3 points if $\mathrm{W} \_$ppm $<3.5$ and ( (As_ppm $>12.75$ and $\left.\leq 26.35\right)$ or ( $\mathrm{Sb}$ ppm $>2.25$ and $\leq 4.65)$ or $\left(\mathrm{Hg} \_\right.$ppm $>0.3$ and $\left.\leq 0.62\right)$ or $\left(\right.$ Se $\_p p m$ $>0.9$ and $\leq 1.86)$ or $($ Te_ppm $>0.0375$ and $\leq 0.0775)$ ) and not $\left((\right.$ As_ppm $>12.75$ and $\leq 26.35)$ and $\left(\mathrm{Sb} \_\right.$ppm $>2.25$ and $\left.\leq 4.65\right)$ and (Hg_ppm $>0.3$ and $\leq 0.62)$ ) and not $\left(\right.$ As_ppm $>12.75$ and $\mathrm{Sb} \_$ppm $>2.25$ and Hg_ppm $>0.3$ and $\left(\mathrm{Se} \_\right.$ppm $>0.9$ or Te_ppm $\left.\left.>0.0375\right)\right)$ )

2 points if $\mathrm{W} \_$ppm $<3.5$ and ( $($ As_ppm $>5.95$ and $\leq 12.75)$ or $\left(\mathrm{Sb} \_\right.$ppm $>1.05$ and $\leq 2.25)$ or $\left(\mathrm{Hg} \_\right.$ppm $>0.14$ and $\left.\leq 0.3\right)$ or $\left(\mathrm{Se} \_\right.$ppm $>0.42$ and $\leq 0.9)$ or $\left(\right.$ Te $\_p p m>0.0175$ and $\left.\left.\leq 0.0375\right)\right)$ and not ( As_ppm $>5.95$ and $\leq 12.75)$ and $\left(\mathrm{Sb} \_\right.$ppm $>1.05$ and $\left.\leq 2.25\right)$ and $(\mathrm{Hg}$. ppm $>0.14$ and $\leq 0.3))$ and not $(($ As ppm $>2.55$ and $\leq 12.75)$ and $(\mathrm{Sb}$ ppm $>0.45$ and $\leq 2.25)$ and $\left(\mathrm{Hg} \_\right.$ppm $>0.06$ and $\left.\leq 0.3\right)$ and $\left(\left(\mathrm{Se} \_\right.\right.$ppm $>0.18$ and $\leq 0.9)$ or $($ Te_ppm $>0.0075$ and $\leq 0.0375))$ )

1 point if $\mathrm{W} \_$ppm $<3.5$ and ( $($ As_ppm $>2.55$ and $\leq 5.95)$ or $\left(\mathrm{Sb} \_\right.$ppm $>0.45$ and $\leq 1.05$ ) or $\left(\mathrm{Hg} \_\right.$ppm $>0.06$ and $\leq 0.14$ ) or $($ Se_ppm $>0.18$ and $\leq 0.42)$ or $\left(\mathrm{Te} \_\right.$ppm $>0.0075$ and $\left.\left.\leq 0.0175\right)\right)$ and not $(($ As_ppm $>2.55$ and $\leq 5.95)$ and $\left(\mathrm{Sb} \_\right.$ppm $>0.45$ and $\left.\leq 1.05\right)$ and $\left(\mathrm{Hg} \_\right.$ppm $>0.06$ and $\leq 0.14))$ and not $(($ As_ppm $>2.55$ and $\leq 12.75)$ and $(\mathrm{Sb}$ ppm $>0.45$ and $\leq 2.25)$ and $\left(\mathrm{Hg} \_\right.$ppm $>0.06$ and $\left.\leq 0.3\right)$ and $\left(\left(\right.\right.$ Se $\_p m$ $>0.18$ and $\leq 0.9)$ or $\left(\right.$ Te $\_p p m>0.0075$ and $\left.\leq 0.0375\right)$ ) $)$ 
Table 10. Scoring template for analysis of potential for porphyry and epithermal gold deposits within each hydrologic unit code (HUC) in Alaska.-Continued

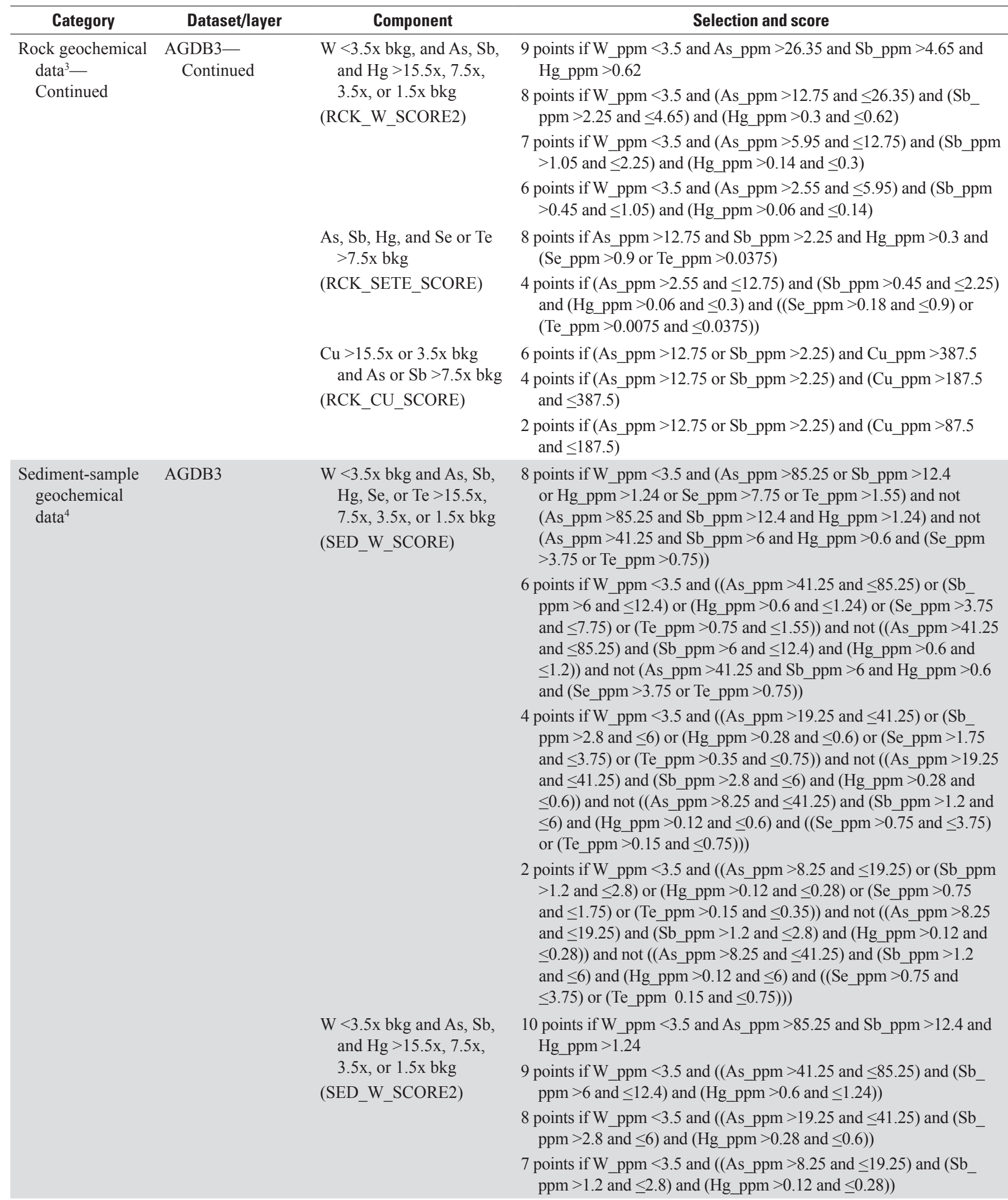


Table 10. Scoring template for analysis of potential for porphyry and epithermal gold deposits within each hydrologic unit code (HUC) in Alaska.-Continued

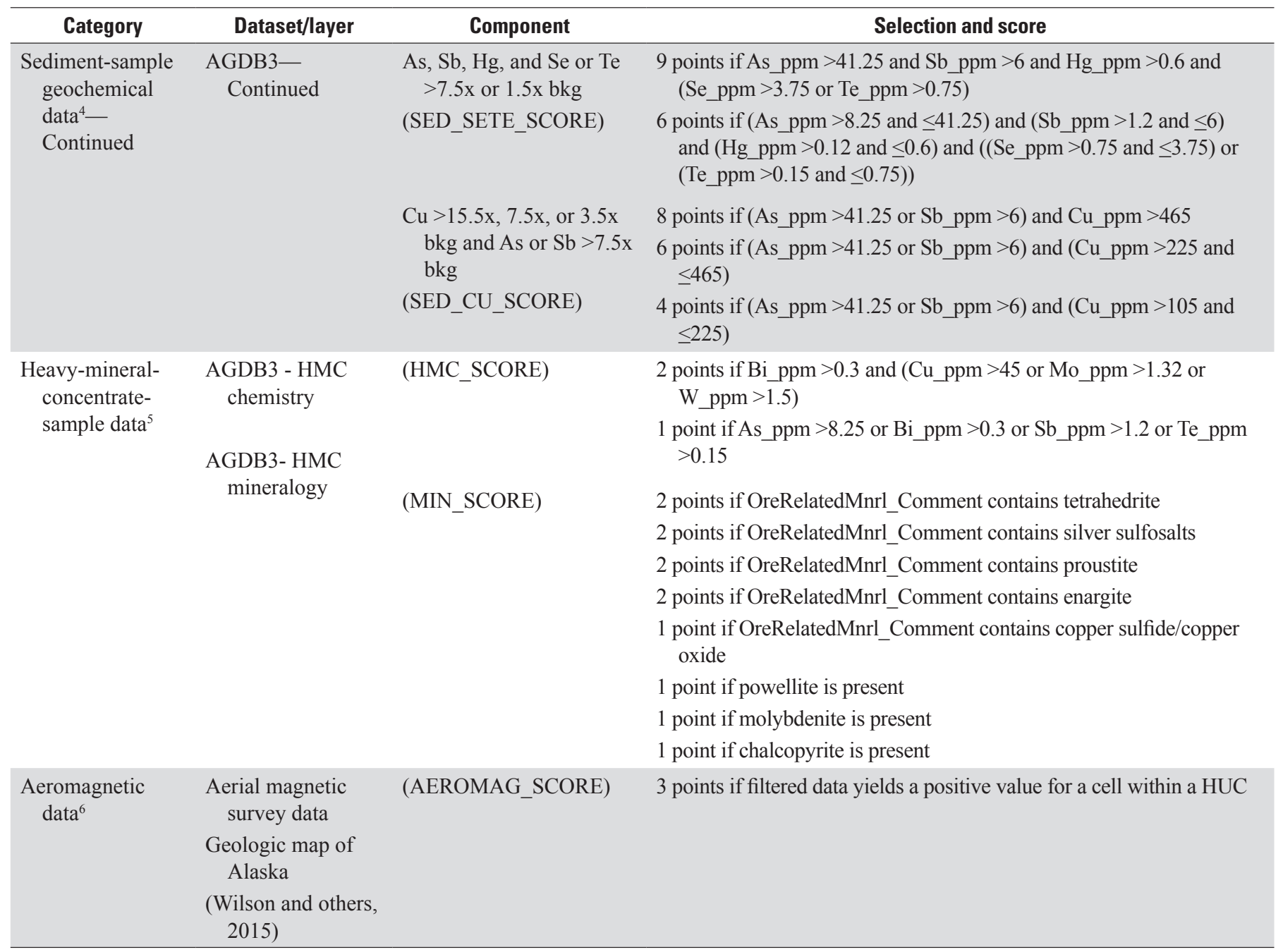

${ }^{1}$ Lithology scores are additive, for a possible total score of 12 for each HUC.

${ }^{2}$ See appendix 2 for a list of lode gold model keywords and the scoring template for ARDF records; maximum single score for a HUC contributes to the total score

${ }^{3}$ Rock geochemical scores are additive, for a possible total score of 27 for each HUC.

${ }^{4}$ Sediment geochemical scores are additive, for a possible total score of 35 for each HUC.

${ }^{5}$ Heavy mineral concentrate scores are additive, for a possible total score of 15 for each HUC.

${ }^{6}$ Aeromagnetic data reduced to the north pole, with upward continuation transform applied and tilt-derivative applied. Only HUCs containing cells that spatially overlap granitoid and hypabyssal rocks were scored. Maximum possible score is 3 points for each HUC. 
Table 11. Mineral resource potential versus certainty classification matrix for porphyry and epithermal gold deposits in Alaska.

[c, certainty; HUC, hydrologic unit code; p, potential]

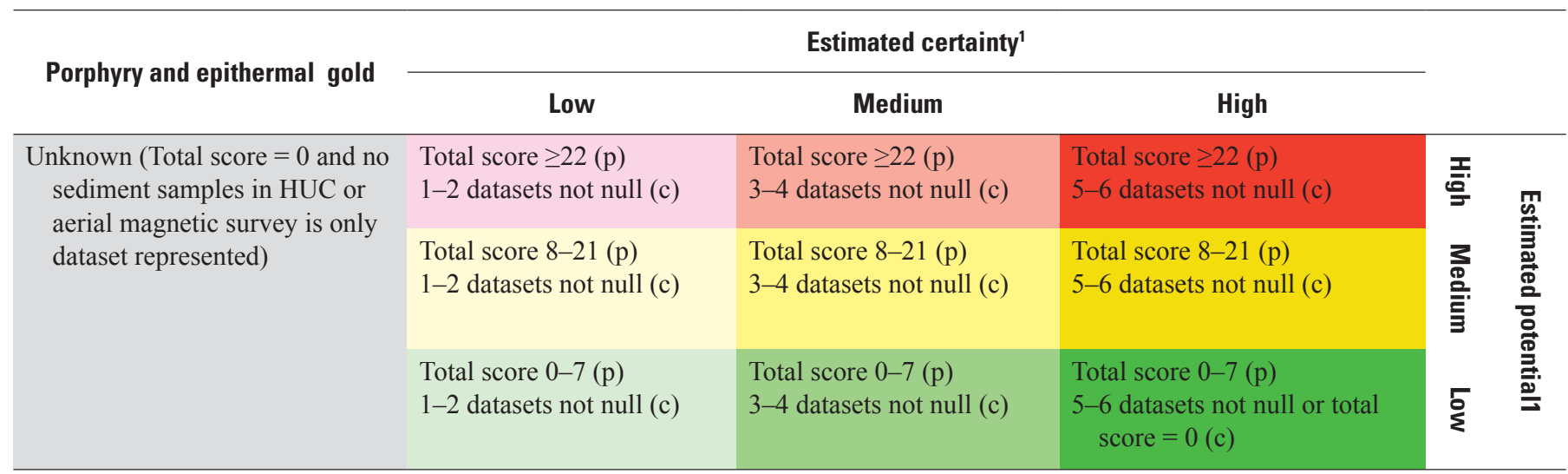

${ }^{1}$ Abbreviations (p) and (c) in cells denote which components contribute to assignment of potential and certainty, respectively.

Table 12. Scoring template for analysis of potential for reduced-intrusion-related and orogenic gold deposits within each hydrologic unit code (HUC) in Alaska.

[AGDB3, Alaska Geochemical Database, version 3.0; ARDF, Alaska Resource Data File; bkg, background concentration (see appendix 1); HMC, heavy mineral concentrate; ppm, parts per million; As, arsenic; $\mathrm{Au}$, gold; $\mathrm{Bi}$, bismuth; $\mathrm{Cu}$, copper; Mo, molybdenum; Pb, lead; Sb, antimony; $\mathrm{Sn}$, tin; Te, tellurium; W, tungsten; $\mathrm{Zn}$, zinc]

\begin{tabular}{|c|c|c|c|}
\hline Category & Dataset/layer & Component & Selection and score \\
\hline Lithology $^{1}$ & $\begin{array}{l}\text { Geologic map of } \\
\text { Alaska (Wilson } \\
\text { and others, 2015) }\end{array}$ & (LITHOLOGY_SCORE) & $\begin{array}{l}3 \text { points if metabasalt or amphibolite-schist } \\
3 \text { points if mica-schist or quartz-feldspar-schist } \\
3 \text { points if carbonaceous metasedimentary } \\
3 \text { points if granite or granodiorite } \\
3 \text { points if diorite, monzonite, or quartz-monzonite } \\
3 \text { points if lamprophyre }\end{array}$ \\
\hline $\begin{array}{l}\text { Rock geochemical } \\
\text { data }^{3}\end{array}$ & AGDB3 & $\begin{array}{c}\mathrm{Cu}, \mathrm{Mo}, \text { or } \mathrm{Sn}>3.5 \mathrm{x} \text { bkg with } \\
\text { As, W, Bi, or Te }>15.5 \mathrm{x} \text {, } \\
7.5 \mathrm{x}, 3.5 \mathrm{x} \text {, or } 1.5 \mathrm{x} \text { bkg } \\
\text { (RCK_CUMOSN_SCORE) }\end{array}$ & 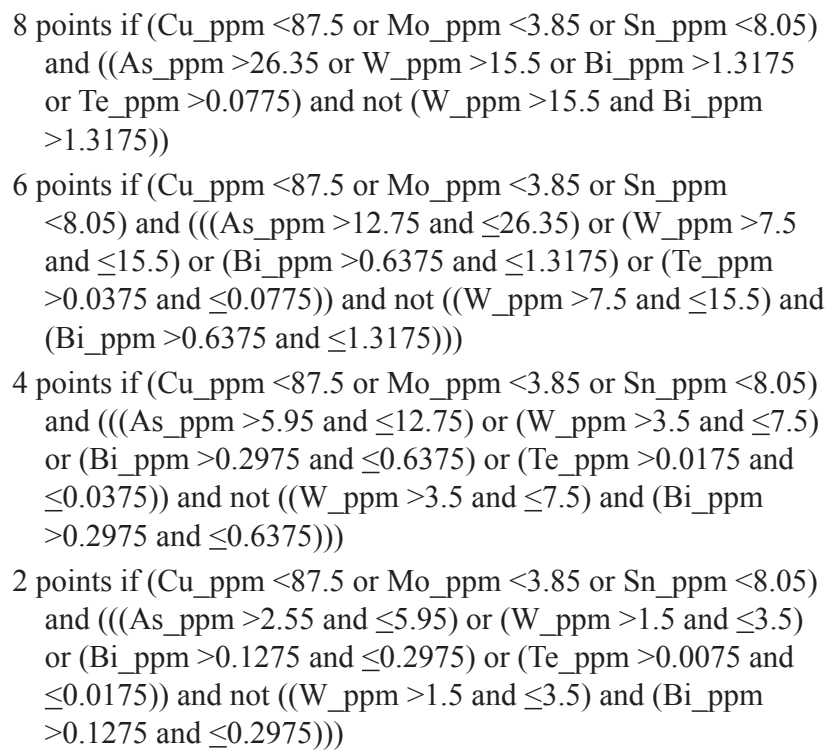 \\
\hline
\end{tabular}


Table 12. Scoring template for analysis of potential for reduced-intrusion-related and orogenic gold deposits within each hydrologic unit code (HUC) in Alaska. - Continued

\begin{tabular}{|c|c|c|c|}
\hline Category & Dataset/layer & Component & Selection and score \\
\hline \multirow{8}{*}{$\begin{array}{l}\text { Rock geochemical } \\
\text { data }{ }^{3}- \\
\text { Continued }\end{array}$} & \multirow[t]{8}{*}{$\begin{array}{l}\text { AGDB3- } \\
\text { Continued }\end{array}$} & \multirow{4}{*}{$\begin{array}{l}\mathrm{Cu}, \mathrm{Mo}, \text { or } \mathrm{Sn}>3.5 \mathrm{x} \text { bkg with } \\
\mathrm{W} \text { and } \mathrm{Bi}>15.5 \mathrm{x}, 7.5 \mathrm{x} \\
3.5 \mathrm{x} \text {, or } 1.5 \mathrm{x} \text { bkg } \\
\text { (RCK_WBI_SCORE) }\end{array}$} & $\begin{array}{l}10 \text { points if }\left(\mathrm{Cu} \_ \text {ppm }<87.5 \text { or } \mathrm{Mo} \_ \text {ppm }<3.85 \text { or } \mathrm{Sn} \_ \text {ppm }\right. \\
<8.05) \text { and }\left(\mathrm{W} \_ \text {ppm }>15.5 \text { and } \mathrm{Bi} \_ \text {ppm }>1.3175\right)\end{array}$ \\
\hline & & & $\begin{array}{l}9 \text { points if }\left(\mathrm{Cu} \_ \text {ppm }<87.5 \text { or } \mathrm{Mo} \_ \text {ppm }<3.85 \text { or } \mathrm{Sn} \_ \text {ppm }<8.05\right) \\
\text { and }\left(\left(\mathrm{W} \_ \text {ppm }>7.5 \text { and } \leq 15.5\right) \text { and }\left(\mathrm{Bi} \_p p m>0.6375 \text { and }\right.\right. \\
\leq 1.3175))\end{array}$ \\
\hline & & & $\begin{array}{l}8 \text { points if }\left(\mathrm{Cu} \_ \text {ppm }<87.5 \text { or } \mathrm{Mo} \_ \text {ppm }<3.85 \text { or } \mathrm{Sn} \_ \text {ppm }<8.05\right) \\
\text { and }\left(\left(\mathrm{W} \_ \text {ppm }>3.5 \text { and } \leq 7.5\right) \text { and }\left(\mathrm{Bi} \_ \text {ppm }>0.2975 \text { and }\right.\right. \\
\leq 0.6375))\end{array}$ \\
\hline & & & $\begin{array}{l}7 \text { points if }\left(\mathrm{Cu} \_ \text {ppm }<87.5 \text { or } \mathrm{Mo} \_ \text {ppm }<3.85 \text { or } \mathrm{Sn} \_ \text {ppm }<8.05\right) \\
\text { and }\left(\left(\mathrm{W} \_ \text {ppm }>1.5 \text { and } \leq 3.5\right) \text { and }\left(\mathrm{Bi} \_ \text {ppm }>0.1275 \text { and }\right.\right. \\
\leq 0.2975))\end{array}$ \\
\hline & & \multirow{4}{*}{$\begin{array}{l}\mathrm{Cu}, \mathrm{Mo} \text { or } \mathrm{Sn}>3.5 \mathrm{x} \text { bkg and } \\
\mathrm{Bi} \text { or } \mathrm{W}>3.5 \mathrm{x} \text { bkg with } \mathrm{Pb} \\
\text { or } \mathrm{Zn}>15.5 \mathrm{x}, 7.5 \mathrm{x}, 3.5 \mathrm{x} \\
\text { or } 1.5 \mathrm{x} \text { bkg } \\
\text { (RCK_PBZN_SCORE) }\end{array}$} & $\begin{array}{l}10 \text { points if }\left(\left(\mathrm{Cu} \_ \text {ppm }<87.5 \text { or } \mathrm{Mo} \_ \text {ppm }<3.85 \text { or } \mathrm{Sn} \_ \text {ppm }\right.\right. \\
\left.\quad<8.05) \text { and }\left(\mathrm{Bi} \_ \text {ppm }>0.2975 \text { or } \mathrm{W} \_ \text {ppm }>3.5\right)\right) \text { and }\left(\mathrm{Pb} \_ \text {ppm }\right. \\
\left.\quad>229.4 \text { or } \mathrm{Zn} \_ \text {ppm }>1007.5\right)\end{array}$ \\
\hline & & & $\begin{array}{l}9 \text { points if }\left(\left(\mathrm{Cu} \_ \text {ppm }<87.5 \text { or } \mathrm{Mo} \_ \text {ppm }<3.85 \text { or } \mathrm{Sn} \_ \text {ppm }\right.\right. \\
\left.\quad<8.05) \text { and }\left(\mathrm{Bi} \_ \text {ppm }>0.2975 \text { or } \mathrm{W} \_ \text {ppm }>3.5\right)\right) \text { and }\left(\left(\mathrm{Pb} \_ \text {ppm }\right.\right. \\
\left.\quad>111 \text { and } \leq 229.4) \text { or }\left(\mathrm{Zn} \_ \text {ppm }>487.5 \text { and } \leq 1007.5\right)\right)\end{array}$ \\
\hline & & & $\begin{array}{l}8 \text { points if }\left(\left(\mathrm{Cu} \_ \text {ppm }<87.5 \text { or } \mathrm{Mo} \_ \text {ppm }<3.85 \text { or } \mathrm{Sn} \_ \text {ppm }\right.\right. \\
\left.\quad<8.05) \text { and }\left(\mathrm{Bi} \_ \text {ppm }>0.2975 \text { or } \mathrm{W} \_ \text {ppm }>3.5\right)\right) \text { and }\left(\left(\mathrm{Pb} \_ \text {ppm }\right.\right. \\
\left.\quad>51.8 \text { and } \leq 111) \text { or }\left(\mathrm{Zn} \_ \text {ppm }>227.5 \text { and } \leq 487.5\right)\right)\end{array}$ \\
\hline & & & $\begin{array}{l}7 \text { points if }\left(\left(\mathrm{Cu} \_ \text {ppm }<87.5 \text { or } \mathrm{Mo} \_ \text {ppm }<3.85 \text { or } \mathrm{Sn} \_ \text {ppm }\right.\right. \\
\left.<8.05) \text { and }\left(\mathrm{Bi} \_ \text {ppm }>0.2975 \text { or } \mathrm{W} \_ \text {ppm }>3.5\right)\right) \text { and }\left(\left(\mathrm{Pb} \_ \text {ppm }\right.\right. \\
\left.>22.2 \text { and } \leq 51.8) \text { or }\left(\mathrm{Zn} \_ \text {ppm }>97.5 \text { and } \leq 227.5\right)\right)\end{array}$ \\
\hline \multirow[t]{8}{*}{$\begin{array}{l}\text { Sediment-sample } \\
\text { geochemical } \\
\text { data }^{4}\end{array}$} & \multirow[t]{8}{*}{ AGDB3 } & \multirow{4}{*}{$\begin{array}{l}\mathrm{Cu}, \mathrm{Mo}, \text { or } \mathrm{Sn}>3.5 \mathrm{x} \text { bkg with } \\
\text { As, W, Bi, or } \mathrm{Sb}>15.5 \mathrm{x} \\
7.5 \mathrm{x}, 3.5 \mathrm{x} \text {, or } 1.5 \mathrm{x} \text { bkg } \\
\text { (SED_CUMOSN_SCORE) }\end{array}$} & $\begin{array}{l}8 \text { points if }\left(\mathrm{Cu} \_ \text {ppm }<105 \text { or } \mathrm{Mo} \_ \text {ppm }<3.08 \text { or } \mathrm{Sn} \_ \text {ppm }<3.5\right) \\
\text { and }\left(\left(\mathrm{As} \_ \text {ppm }>85.25 \text { or } \mathrm{W} \_ \text {ppm }>15.5 \text { or } \mathrm{Bi} \_ \text {ppm }>3.1 \text { or }\right.\right. \\
\left.\text { Sb_ppm }>12.4) \text { and not }\left(\mathrm{W} \_ \text {ppm }>15.5 \text { or } \mathrm{Bi} \_ \text {ppm }>3.1\right)\right)\end{array}$ \\
\hline & & & $\begin{array}{l}6 \text { points if }\left(\mathrm{Cu} \_ \text {ppm }<105 \text { or } \mathrm{Mo} \_ \text {ppm }<3.08 \text { or } \mathrm{Sn} \_ \text {ppm }<3.5\right) \\
\text { and }\left(\left(\left(\mathrm{As} \_ \text {ppm }>41.25 \text { and } \leq 85.25\right) \text { or }\left(\mathrm{W} \_ \text {ppm }>7.5 \text { and }\right.\right.\right. \\
\left.\leq 15.5) \text { or }\left(\mathrm{Bi} \_ \text {ppm }>1.5 \text { and } \leq 3.1\right) \text { or }\left(\mathrm{Sb} \_ \text {ppm }>6 \text { and } \leq 12.4\right)\right) \\
\text { and not }\left(\left(\mathrm{W} \_ \text {ppm }>7.5 \text { and } \leq 15.5\right) \text { and }\left(\mathrm{Bi} \_ \text {ppm }>1.5 \text { and }\right.\right. \\
\leq 3.1)))\end{array}$ \\
\hline & & & $\begin{array}{l}4 \text { points if }\left(\mathrm{Cu} \_ \text {ppm }<105 \text { or } \mathrm{Mo} \_ \text {ppm }<3.08 \text { or } \mathrm{Sn} \_ \text {ppm }<3.5\right) \\
\text { and }\left(\left(\left(\mathrm{As} \_ \text {ppm }>19.25 \text { and } \leq 41.25\right) \text { or }\left(\mathrm{W} \_ \text {ppm }>3.5 \text { and }\right.\right.\right. \\
\left.\leq 7.5) \text { or }\left(\mathrm{Bi} \_ \text {ppm }>0.7 \text { and } \leq 1.5\right) \text { or }\left(\mathrm{Sb} \_ \text {ppm }>2.8 \text { and } \leq 6\right)\right) \\
\text { and not }\left(\left(\mathrm{W} \_ \text {ppm }>3.5 \text { and } \leq 7.5\right) \text { and }\left(\mathrm{Bi} \_ \text {ppm }>0.7 \text { and }\right.\right. \\
\leq 1.5)))\end{array}$ \\
\hline & & & $\begin{array}{c}2 \text { points if }\left(\mathrm{Cu} \_ \text {ppm }<105 \text { or } \mathrm{Mo} \_ \text {ppm }<3.08 \text { or } \mathrm{Sn} \_ \text {ppm }<3.5\right) \\
\text { and }\left(\left(\left(\mathrm{As} \_ \text {ppm }>8.25 \text { and } \leq 19.25\right) \text { or }\left(\mathrm{W} \_ \text {ppm }>1.5 \text { and }<3.5\right)\right.\right. \\
\left.\text { or }\left(\mathrm{Bi} \_ \text {ppm }>0.3 \text { and } \leq 0.7\right) \text { or }\left(\mathrm{Sb} \_ \text {ppm }>1.2 \text { and } \leq 2.8\right)\right) \text { and } \\
\left.\text { not }\left(\left(\mathrm{W} \_ \text {ppm }>1.5 \text { and } \leq 3.5\right) \text { and }\left(\mathrm{Bi} \_ \text {ppm } 0.3 \text { and } \leq 0.7\right)\right)\right)\end{array}$ \\
\hline & & \multirow{4}{*}{$\begin{array}{l}\mathrm{Cu}, \mathrm{Mo}, \text { or } \mathrm{Sn}>3.5 \mathrm{x} \text { bkg with } \\
\mathrm{W} \text { and } \mathrm{Bi}>15.5 \mathrm{x}, 7.5 \mathrm{x} \\
3.5 \mathrm{x}, \text { or } 1.5 \mathrm{x} \text { bkg } \\
\text { (SED_WBI_SCORE) }\end{array}$} & $\begin{array}{l}10 \text { points if }\left(\mathrm{Cu} \_ \text {ppm }<105 \text { or } \mathrm{Mo} \_ \text {ppm }<3.08 \text { or } \mathrm{Sn} \_ \text {ppm }<3.5\right) \\
\text { and }\left(\mathrm{W} \_ \text {ppm }>15.5 \text { and } \mathrm{Bi} \_ \text {ppm }>3.1\right)\end{array}$ \\
\hline & & & $\begin{array}{l}9 \text { points if }\left(\mathrm{Cu} \_ \text {ppm }<105 \text { or } \mathrm{Mo} \_ \text {ppm }<3.08 \text { or } \mathrm{Sn} \_ \text {ppm }<3.5\right) \\
\text { and }\left(\left(\mathrm{W} \_ \text {ppm }>7.5 \text { and } \leq 15.5\right) \text { and }\left(\mathrm{Bi} \_ \text {ppm }>1.5 \text { and } \leq 3.1\right)\right)\end{array}$ \\
\hline & & & $\begin{array}{l}8 \text { points if }\left(\mathrm{Cu} \_ \text {ppm }<105 \text { or } \mathrm{Mo} \_ \text {ppm }<3.08 \text { or } \mathrm{Sn} \_ \text {ppm }<3.5\right) \\
\text { and }\left(\left(\mathrm{W} \_ \text {ppm }>3.5 \text { and } \leq 7.5\right) \text { and }\left(\mathrm{Bi} \_ \text {ppm }>0.7 \text { and } \leq 1.5\right)\right)\end{array}$ \\
\hline & & & $\begin{array}{c}7 \text { points if }\left(\mathrm{Cu} \_ \text {ppm }<105 \text { or } \mathrm{Mo} \_ \text {ppm }<3.08 \text { or } \mathrm{Sn} \_ \text {ppm }<3.5\right) \\
\text { and }\left(\left(\mathrm{W} \_ \text {ppm }>1.5 \text { and } \leq 3.5\right) \text { and }\left(\mathrm{Bi} \_ \text {ppm }>0.3 \text { and } \leq 0.7\right)\right)\end{array}$ \\
\hline
\end{tabular}


Table 12. Scoring template for analysis of potential for reduced-intrusion-related and orogenic gold deposits within each hydrologic unit code (HUC) in Alaska. - Continued

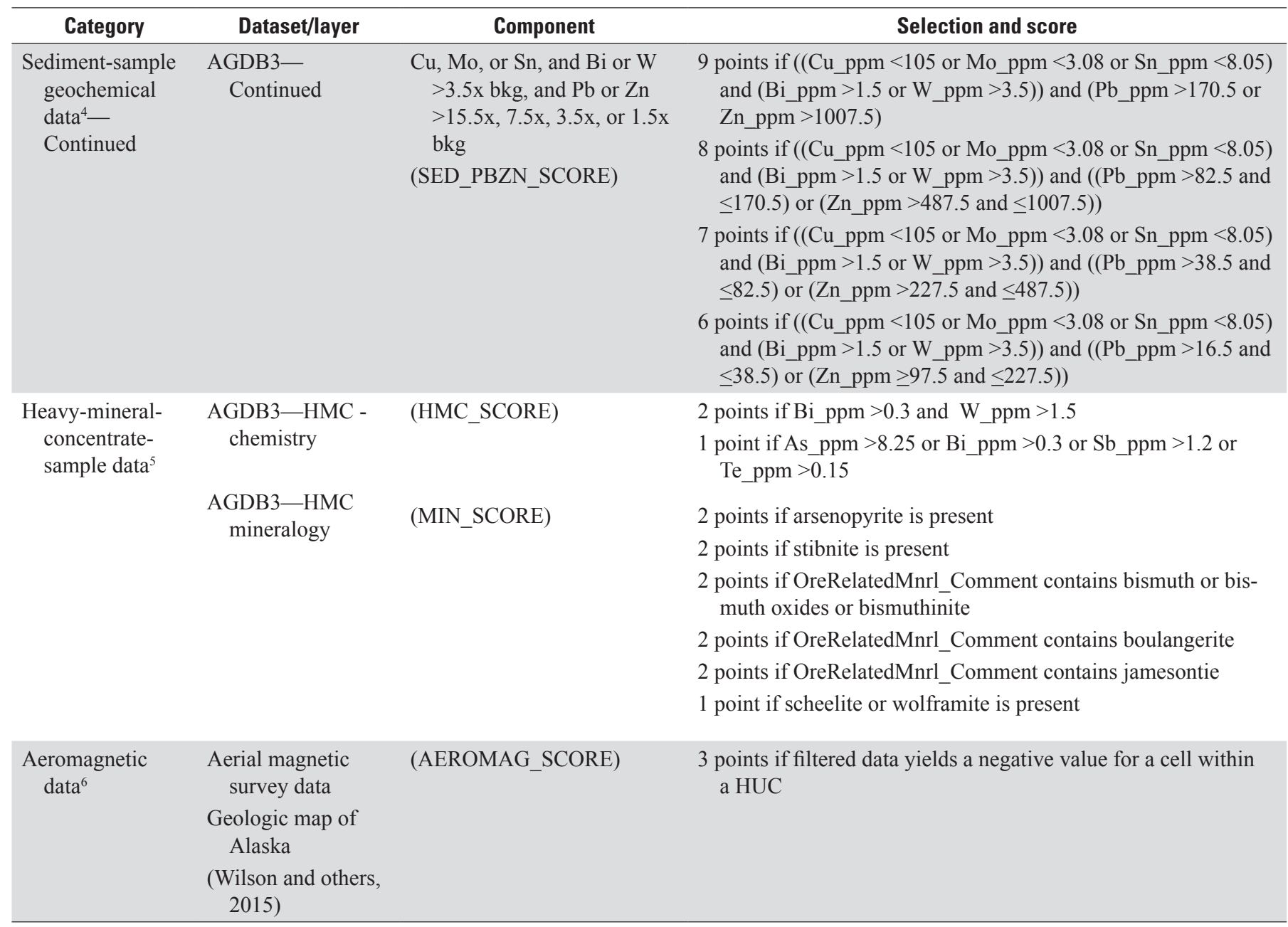

${ }^{1}$ Lithology scores are additive, for a possible total score of 18 for each HUC.

${ }^{2}$ See appendix 2 for a list of lode gold model keywords and the scoring template for ARDF records; maximum single score for a HUC contributes to the total score.

${ }^{3}$ Rock geochemical scores are additive, for a possible total score of 28 for each HUC.

${ }^{4}$ Sediment geochemical scores are additive, for a possible total score of 27 for each HUC.

${ }^{5}$ Heavy mineral concentrate scores are additive, for a possible total score of 13 for each HUC.

${ }^{6}$ Aeromagnetic data reduced to the north pole, with upward continuation transform applied and tilt-derivative applied. Only HUCs containing cells that spatially overlap granitoid and hypabyssal rocks were scored. Maximum possible score is 3 points for each HUC. 
Table 13. Mineral resource potential versus certainty classification matrix for reduced-intrusion-related and orogenic gold deposits in Alaska.

[c, certainty; HUC, hydrologic unit code; p, potential]

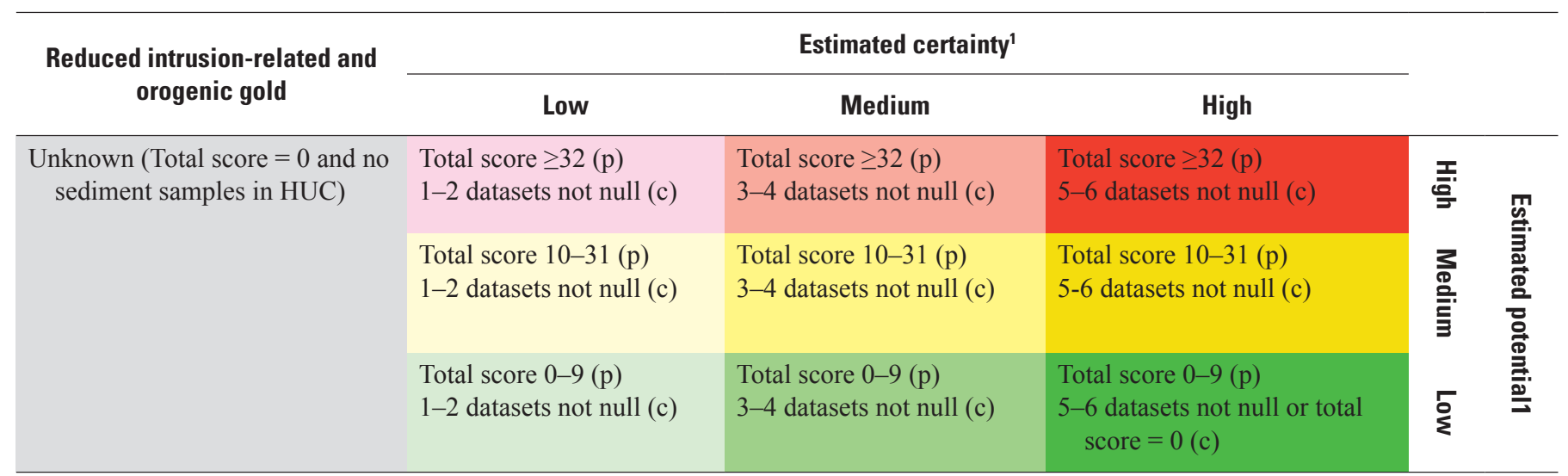

${ }^{1}$ Abbreviations (p) and (c) in cells denote which components contribute to assignment of potential and certainty, respectively. 


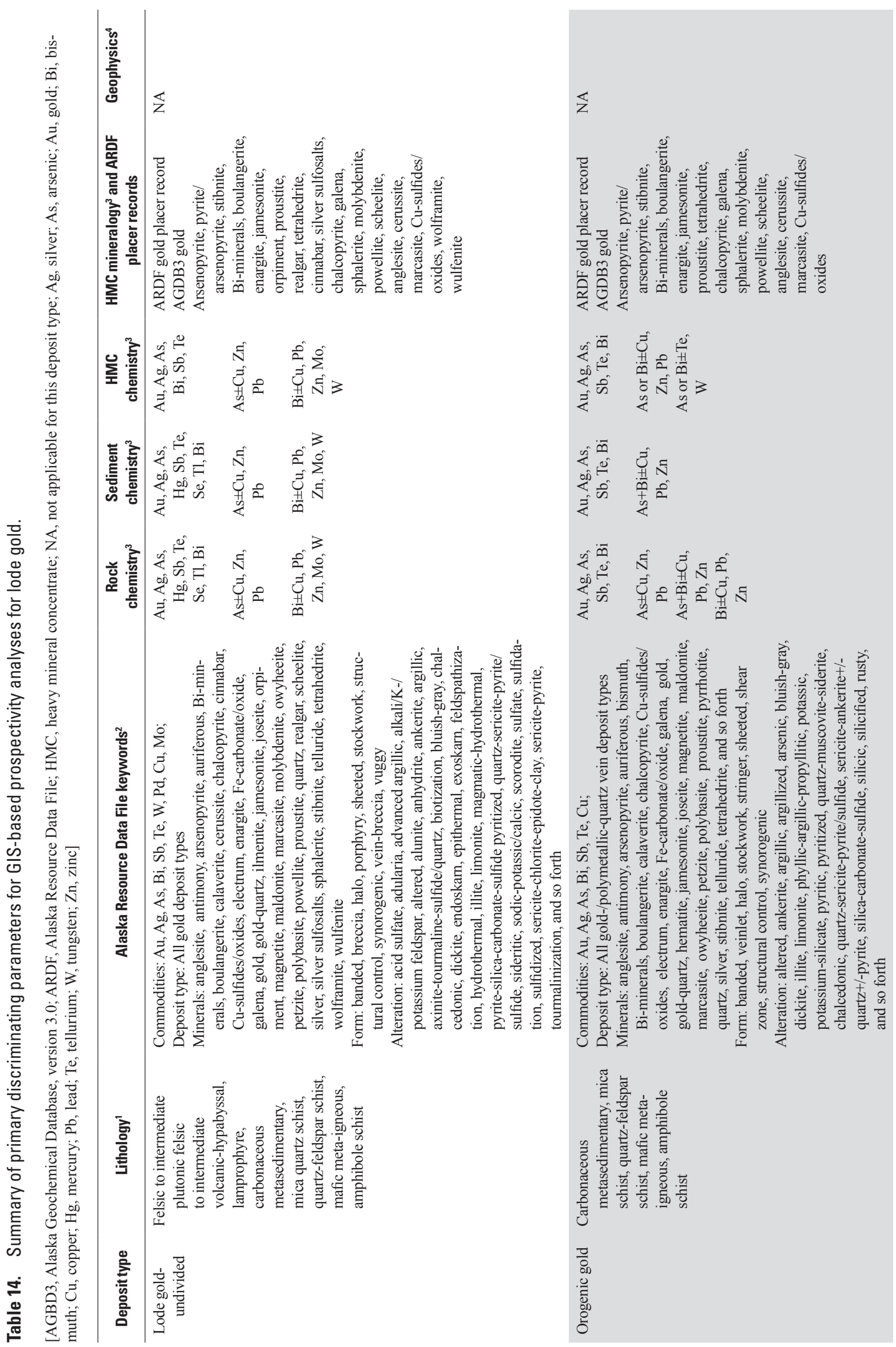




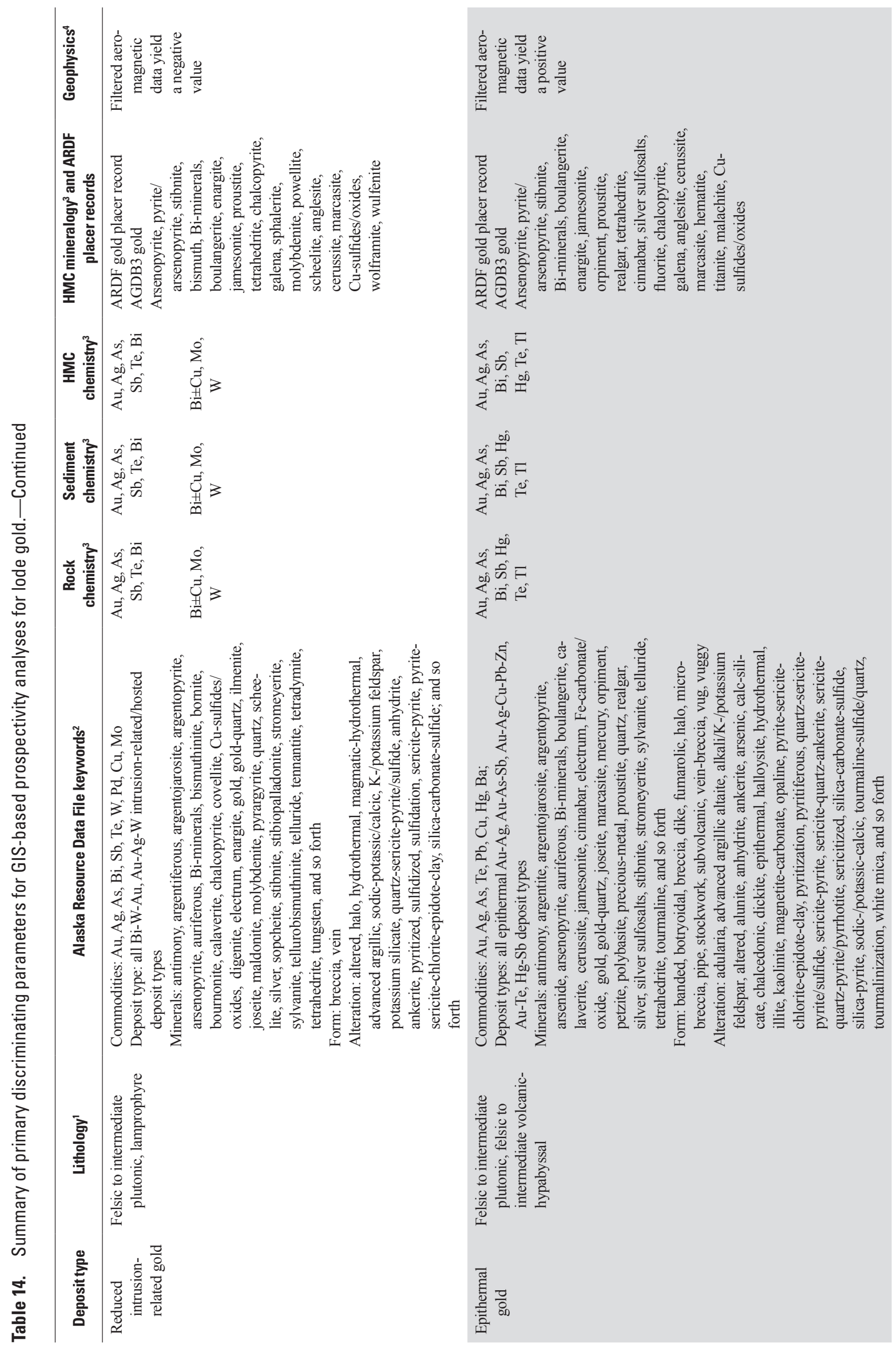




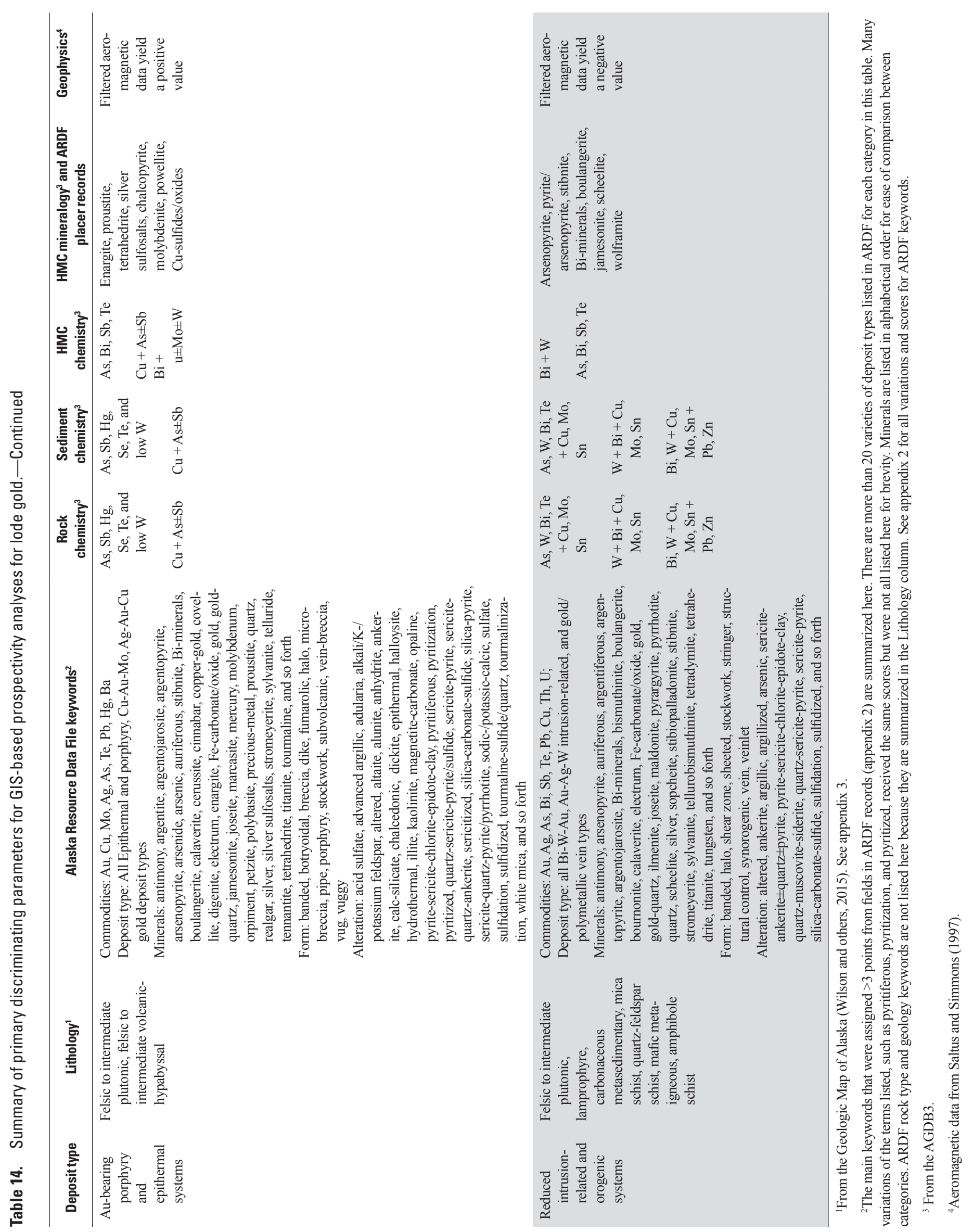




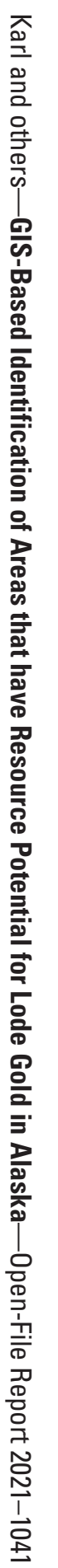

